MURILO GASPARDO

O Parlamento e o Controle do Poder Político

FACULDADE DE DIREITO DA UNIVERSIDADE DE SÃO PAULO

SÃO PAULO - SP

2009 


\title{
O Parlamento e o Controle do Poder Político
}

\author{
Dissertação apresentada junto ao Departamento de \\ Direito do Estado da Faculdade de Direito da \\ Universidade de São Paulo, como exigência parcial \\ para obtenção do título de Mestre em Direito do \\ Estado.
}

Orientador: Professor Doutor Sebastião Botto de Barros Tojal.

\section{FACULDADE DE DIREITO DA UNIVERSIDADE DE SÃO PAULO \\ SÃO PAULO - SP 2009}




\section{ÍNDICE}

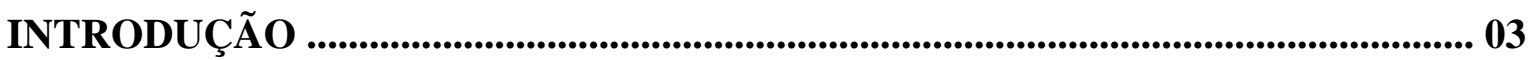

CAPÍTULO 1 - DELIMITAÇÃO DO OBJETO DA PESQUISA .................................. 07

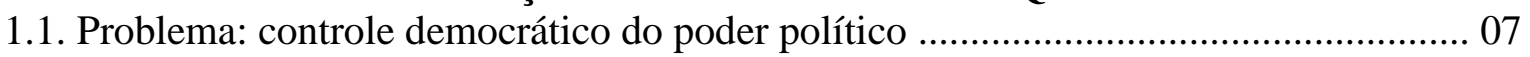

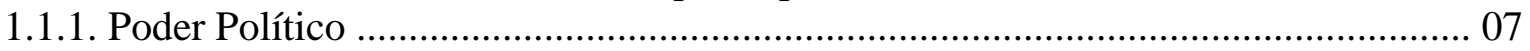

1.1.2. Controle do Poder Político no Estado Democrático de Direito ............................... 14

1.1.3. O Controle Democrático do Poder Político frente à Economia .............................. 34

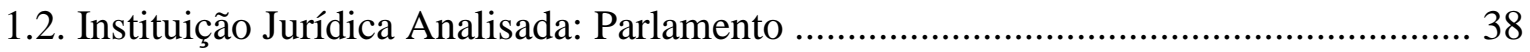

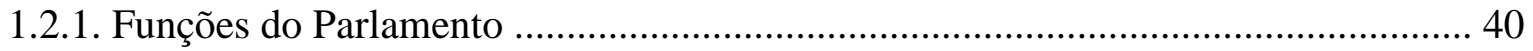

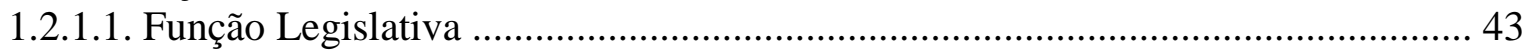

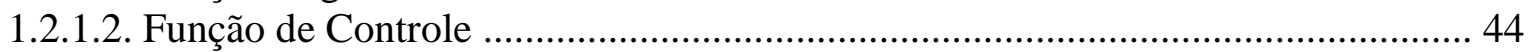

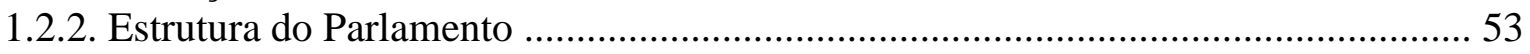

1.3. Contexto da Análise do Problema: Globalização Capitalista ....................................... 55

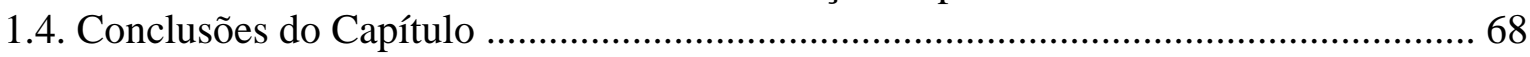

CAPÍTULO 2 - LIMITES E POSSIBILIDADES DA ATUAÇÃO DO PARLAMENTO NO CONTROLE DEMOCRÁTICO DO PODER POLÍTICO ..... 72

2.1. Considerações Gerais sobre a Separação de Poderes ................................................. 72

2.2. Limites para o Cumprimento da Missão Institucional do Parlamento decorrentes de sua

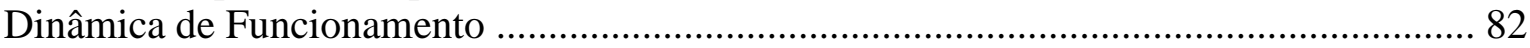

2.3. Transferência de Poder Normativo do Parlamento para o Executivo .......................... 89

2.4. Tecnificação e Falsa Despolitização das Decisões Políticas ........................................ 95

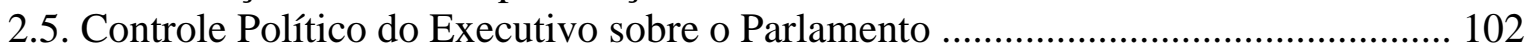

2.6. O Parlamento e a Definição do Orçamento Público ..................................................... 114

2.7. Judicialização da Política e Politização da Justiça .................................................... 123

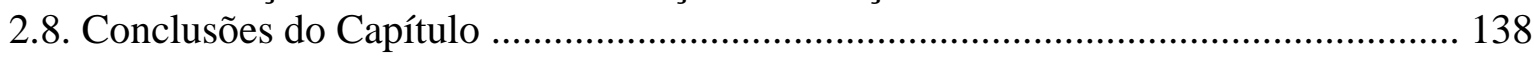

CAPÍTULO 3 - CONTROLE POPULAR SOBRE O PARLAMENTO ..................... 142

3.1. Considerações Gerais sobre a Representação Política ............................................. 142

3.2. Controle Popular sobre o Parlamento por meio das Eleições .................................. 155

3.3. Outros meios de Controle Popular sobre o Parlamento .............................................. 169

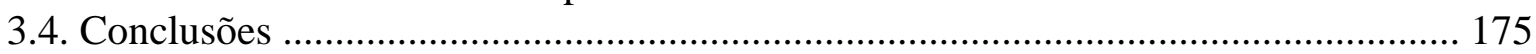

CAPÍTULO 4 - PERSPECTIVAS SOBRE A ATUAÇÃO DO PARLAMENTO NO CONTROLE DEMOCRÁTICO DO PODER ................................................................ 177

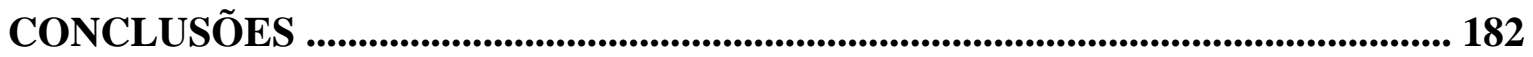

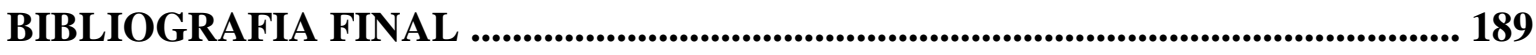




\section{Introdução}

O presente estudo se propõe a investigar em que medida o Parlamento é capaz de exercer, eficazmente, o controle do poder político, no contexto da globalização capitalista, com o objetivo de contribuir com a concretização dos direitos humanos econômicos e sociais.

Trata-se de um problema de grande atualidade e relevância, tanto doutrinária como prática.

Do ponto de vista doutrinário, salienta-se que o controle do poder político é uma das questões mais antigas, fundamentais e, ainda, sem conclusões definitivas da Teoria Geral do Estado. No contexto da globalização e do Pós-positivismo Jurídico, em que o padrão de juridicidade, tradicionalmente decorrente da lei, se desloca para a Constituição, a questão adquire renovada importância e atualidade.

Quanto ao aspecto prático, observa-se que é recorrente o debate sobre a necessidade de se promover uma ampla reforma política a fim de se aperfeiçoar as instituições que regem a dinâmica do poder. Todavia, as abordagens sobre essa reforma se limitam a discutir regras sobre os partidos políticos e o processo eleitoral, como as referentes ao número de partidos, a fidelidade partidária, ao sistema eleitoral e ao financiamento de campanhas, sem que seja atacada a questão fundamental: a redefinição do próprio papel das instituições do Estado, as quais foram forjadas em um momento histórico radicalmente diferente do atual. Portanto, analisar aspecto tão relevante desse problema, que é a atuação do Parlamento, consiste em uma tarefa que precisa ser realizada no campo de investigação jurídica da Teoria Geral do Estado.

Quanto à metodologia, ressalta-se, inicialmente, que o problema investigado apresenta um inerente caráter multidisciplinar. Entretanto, a sede epistemológica desta pesquisa é normativa, ou seja, encontra-se no campo do dever-ser, e não dos estudos empíricos. Situa-se, mais precisamente, na área de investigação da Teoria Geral do Estado, pois trata do regime político na perspectiva de uma mudança de época. Portanto, far-se-á uma análise sob as perspectivas institucional e de Direito Público, de caráter geral, conceitual e prescritivo.

Porém, para que seja possível fazer prescrições sobre as possibilidades da atuação do Parlamento no controle do poder político e sobre uma redefinição de seu papel institucional na concretização dos direitos humanos econômicos e sociais, é preciso analisar suas limitações e os pontos de estrangulamento que apresenta diante da realidade 
fática. Para tanto, é necessário recorrer não só a estudos da área de Direito Público, mas também a outros ramos do saber, como a Sociologia, a Sociologia Jurídica, a Teoria do Direito, a Filosofia e a Ciência Política. Ressalva-se, todavia, que referências a pesquisas empíricas servirão somente para melhor aferir os limites e as possibilidades da atuação do Parlamento.

No que se refere à bibliografia, procurou-se analisar, inicialmente, os autores clássicos que estudaram o Parlamento e os assuntos relacionados com sua atuação no controle democrático do poder político. Em seguida, passou-se a estudar os trabalhos mais recentes que cuidaram do problema desta pesquisa, especialmente na área do Direito Público. Por fim, procedeu-se a um controle bibliográfico em relação aos principais manuais de Teoria Geral do Estado e Direito Constitucional, verificando as contribuições que seus autores deram para a questão em análise. Ressalva-se que não foi adotado nenhum modelo teórico específico para a análise do tema desta dissertação, recorrendo-se a diversas alternativas na busca de melhor compreender o problema estudado.

Feitas essas considerações sobre a relevância do tema e a metodologia adotada, passa-se à delimitação do problema desta dissertação.

Quando se discute o controle do poder político, neste trabalho, não se está fazendo referência à perspectiva liberal de contenção do poder do Estado para salvaguardar a liberdade. Também não se está discutindo simplesmente a fiscalização dos atos dos agentes estatais e o combate à corrupção e ao desvio de recursos públicos para finalidades privadas. Compreende-se o controle no sentido forte de direcionamento das ações do Estado para que cumpra seus fins, sendo que esta dissertação se dedica especialmente ao fim estatal da concretização dos direitos humanos econômicos e sociais.

Para que o controle seja democrático, é preciso que o direcionamento das ações do Estado seja feito de maneira efetiva, e não somente simbólica, pela totalidade do povo. Como nos Estados contemporâneos o governo direto não se revela possível, esse direcionamento se dá por meio da fixação de metas e diretrizes, da supervisão e da responsabilização dos agentes políticos.

Para que o controle democrático seja operado, diversas instituições devem cumprir adequadamente seu papel e, entre elas, destaca-se aqui o Parlamento.

Com as Revoluções Liberais, atribuiu-se ao Parlamento o papel da formulação da vontade do Estado por meio das leis. Entretanto, nas suas origens, ele não apresentava um caráter democrático, o qual só começou a se manifestar com a universalização do sufrágio. Mesmo assim, permanecia a idéia de controle como contenção do poder. 
Desde que o Estado assumiu novas funções, nas primeiras décadas do século $\mathrm{XX}$ até os dias de hoje, passou a ser frequente a afirmação de que o Parlamento perdeu a primazia legislativa, a capacidade de exercer o controle do poder (ainda no sentido fraco), e a própria credibilidade, devido aos frequentes escândalos de corrupção, o que afeta diretamente a base de sua existência, que é a representatividade. Essas questões acabaram por se agravar com o aprofundamento da globalização capitalista a partir dos mais recentes avanços nos campos da comunicação e dos transportes.

Assim sendo, desapegando-se das concepções que remontam aos séculos XVIII e XIX, é preciso repensar o papel do Parlamento no controle democrático do poder político, neste início de século XXI, a partir do confronto entre as realidades institucional e fática.

Partindo-se da premissa segundo a qual o Parlamento, enquanto instituição do Estado Democrático de Direito, tem como papel fundamental contribuir com a concretização dos direitos econômicos e sociais, pode-se sintetizar o objeto desta pesquisa na seguinte questão: o Parlamento, no contexto da globalização capitalista, é capaz de realizar, a contento, o controle do poder político, cumprindo sua missão institucional na concretização dos direitos humanos econômicos e sociais?

Existem três hipóteses de resposta para essa pergunta: (1) não, o Parlamento não é capaz de realizar a contento o controle democrático do poder político, pois seu papel institucional foi esvaziado, de maneira que a concretização dos direitos humanos econômicos e sociais compete aos Poderes Executivo e Judiciário, ou ao mercado e às instituições da sociedade civil; (2) sim, o Parlamento pode realizar plenamente tal tarefa, ocupando ainda o centro da vida política, tal como na época de suas origens, porém, agora, a partir da compreensão da idéia de controle como direcionamento e não como contenção; (3) o Parlamento tem um papel fundamental no controle do poder político para a concretização dos direitos econômicos e sociais, porém sua atuação tem limites e apresenta vários pontos de estrangulamento, de maneira que é preciso definir, com clareza, as possibilidades de sua atuação, a fim de que sejam adequadamente desenvolvidas, por meio da revisão de seu desenho institucional.

Adotar-se-á a terceira posição, reconhecendo-se o papel fundamental do Parlamento, porém sem se atribuir a ele tarefas que não é capaz de cumprir, gerando-se expectativas que jamais serão concretizadas, o que implica a necessidade de a sociedade desenvolver outras formas de controle. 
O primeiro Capítulo será dedicado à delimitação do objeto da pesquisa. Primeiramente será definido o problema abordado nesta dissertação, qual seja: o controle do poder político no Estado Democrático de Direito e frente ao Poder Econômico, pois a efetividade do controle democrático do poder se mostra bastante reduzida se não abranger as questões econômicas. Em segundo lugar, será feita uma apresentação da instituição jurídica em estudo: o Parlamento. Por último, será apresentado o contexto da análise do problema: a globalização capitalista.

No Capítulo 2, serão discutidos os limites e as possibilidades da atuação do Parlamento no controle democrático do poder político para a concretização dos direitos humanos econômicos e sociais. Inicialmente, serão feitas algumas considerações gerais sobre a separação de poderes. Em seguida, serão analisadas cada uma das limitações que se apresentam: (1) a própria dinâmica de funcionamento e de controle do poder dentro do Parlamento; (2) a transferência de poder normativo do Legislativo para o Executivo; (3) a tecnificação e a falsa despolitização das decisões políticas; (4) o controle político do Executivo sobre o Parlamento (5) a definição do orçamento público; e (6) a judicialização da política e politização da justiça.

Resta ainda outra limitação à atuação Parlamentar no controle democrático do poder político: a fragilidade do controle popular sobre o Parlamento, a qual funciona como um desestímulo ao desempenho de sua missão institucional. Além disso, ainda que o controle exercido pelo Parlamento sobre o Executivo fosse eficiente, isso de nada adiantaria diante de sua não submissão à soberania popular. Esse assunto será tratado no Capítulo 3, o qual se iniciará com algumas considerações gerais sobre a Representação Política. Depois, serão discutidos os limites e as possibilidades do controle popular sobre o Parlamento nas eleições e além dos momentos eleitorais.

No Capítulo 4, retomando-se a questão que motivou esta pesquisa, serão traçadas algumas perspectivas sobre a atuação do Parlamento no controle democrático do poder pelo Parlamento no contexto da globalização, reconhecendo-se seus limites, discutindo a maneira como a sociedade vai conviver com eles e apontando algumas possibilidades. 


\section{CAPÍTULO 1 - DELIMITAÇÃO DO OBJETO DA PESQUISA.}

Neste Capítulo, delimitar-se-á o objeto desta dissertação. Primeiramente, será definido o problema de que trata esta pesquisa: o controle do poder político, no Estado Democrático de Direito, com a finalidade de promover a concretização dos direitos econômicos e sociais. Em segundo lugar, será apresentada a instituição jurídica em estudo: o Parlamento. Por último, será discutido o contexto da análise do problema: a globalização capitalista.

\subsection{Problema: Controle Democrático do Poder Político.}

\subsubsection{Poder Político.}

Neste item, precisar-se-á o uso que se fará da expressão "poder político" ao longo desta pesquisa. Para tanto, serão apresentadas considerações sobre o poder (gênero), o Estado (lugar em que se manifesta o poder político) e sobre a legitimidade, questão inerente a qualquer discussão sobre o poder, sem a pretensão de aprofundar tais temáticas.

O poder consiste na capacidade de um sujeito impor sua vontade a outro, o que não depende somente das habilidades do primeiro, mas também da cooperação e do consentimento do último. O poder não se confunde com a força física, pois esta suprimiria a própria vontade de seu destinatário. Porém, o potencial do uso da força é inerente ao poder, pois, em caso contrário, haveria somente persuasão e não sujeição. ${ }^{1}$

Existem diferentes formas de poder: político, econômico, religioso, moral, técnico etc. Todas elas se relacionam, influenciam-se e apresentam uma tendência ilimitada de expansão e fortalecimento ${ }^{2}$, a qual precisa ser contida por instituições sociais capazes de impor limites e impedir o arbítrio (COMPARATO, 2005, p. XV - XVI).

\footnotetext{
${ }^{1}$ Cf. BEETHAM, 1991, p. 38 e BASTOS, 1988, p. 132.

${ }^{2}$ Uma das razões para a tendência de expansão e fortalecimento do poder é que a busca por sua conquista e manutenção se revela como uma das mais fortes paixões do homem, cujo objeto, muito mais do que o resultado de seu exercício, ou seja, as transformações na realidade que podem decorrer da ação daquele que o detém, é seu próprio exercício, pois o respeito, a veneração e a submissão que ele muitas vezes desperta é que causam prazer no seu detentor. Essa paixão acaba fazendo com que aquele que exerce o poder sem limitações acabe sendo dominado por ele, procurando conservá-lo e ampliá-lo a qualquer custo, inclusive se corrompendo (COMPARATO, 2006, p. 589 - 591).
} 
O problema do poder político ${ }^{3}$ surge quando os homens, vivendo em sociedade, precisam resolver questões que não se referem somente ao indivíduo, mas a toda a coletividade (BASTOS, 1988, p. 107 - 108).

Modernamente, o poder político é aquele exercido no âmbito do Estado ${ }^{4}$, instituição fundamental das Ciências Jurídicas e Sociais, cujo estudo e definição são alvos de intermináveis controvérsias ${ }^{5}$.

Adotar-se-á a clássica definição de Dallari (2001, p. 118) que, considerando o fim $^{6}$ e a juridicidade do Estado como características fundamentais, assim o define: trata-se de uma "ordem jurídica soberana que tem por fim o bem comum ${ }^{7}$ de um povo situado em determinado território".

\footnotetext{
${ }^{3}$ Aristóteles (2003, p. 99) ressalta que todas as ciências e artes têm como finalidade o bem, sendo que a política é a maior de todas as ciências e sua finalidade é o maior de todos os bens: a justiça.

${ }^{4}$ Segundo a historiografia política, o Estado Moderno se estruturou na Europa nos séculos XV, XVI e XVII, substituindo a forma medieval de organização político-jurídica, mediante a concentração do poder que era exercido de maneira difusa nas mãos dos monarcas. Cf. SALDANHA, 1987, p. 5 e BASTOS, 1988, p. 109. Bendix (1986, p. 323) ressalta que, segundo Weber, o Estado moderno existe onde a comunidade política possui as seguintes características: 1) uma ordem administrativa e jurídica sujeita a alterações através da legislação; 2) um aparelho administrativo que conduza os assuntos oficiais de acordo com a regulamentação legislativa; 3 ) autoridade com poder sobre todas as pessoas - que normalmente obtêm a cidadania com o nascimento - e sobre a maioria das ações que acontecem na área de sua jurisdição; 4) a legitimação para usar a força dentro de sua área quando a coerção é permitida ou recomendada pelo governo legalmente constituído, isto é, se estiver de acordo com algum estatuto promulgado.

${ }^{5}$ Os teóricos positivistas (Gerber, Laban, Orlando, Jellinek, Kelsen) do Estado, buscaram conhecê-lo por meio de uma metodologia exclusivamente jurídica, ou seja, emancipando o conhecimento científico da realidade histórico-social. Assim, construíram uma teoria jurídica do Estado, universal, aplicável à generalidade dos Estados, independente do tempo e do espaço, a qual o estuda sob a perspectiva do "deverser" e o compreende como um "sistema de normas". Entretanto, essa teoria inviabiliza o conhecimento do Estado concreto, o isola da Política, reduz seu conhecimento a um de seus elementos (o ordenamento jurídico) e a legitimidade à legalidade, o que impossibilita a compreensão da totalidade do fenômeno estatal. Diferente é a perspectiva de estudo da Teoria do Estado como "ciência da realidade" (Heller), na qual o "objeto de investigação passa a ser a função do Estado dentro da realidade social concreta, rejeitando-se a idéia de que o Estado é invariável, constante ao longo do tempo". Segundo essa última teoria, "o Estado deve ser entendido historicamente, vinculado às relações político-ideológicas e de poder, que o conformam" (BERCOVICI, 2000, p. 22 - 28).

${ }^{6}$ Bobbio $(1998,164)$ aponta diferentes fins que foram atribuídos ao Estado ao longo da história: é ora a justiça (Platão), ora o bem comum (Aristóteles), a felicidade dos súditos (Leibnitz), a liberdade (Kant), a máxima expressão do ethos de um povo (Hegel). É considerado geralmente como o ponto de escape da barbárie, da guerra de todos contra todos; visto como o domínio da razão sobre as paixões, da reflexão sobre o instinto. Grande parte da filosofia política é uma glorificação do Estado. Marx, ao contrário, considera o Estado como puro e simples 'instrumento' de domínio. Heller (2002, p. 260) define a função do Estado da seguinte maneira: consiste, pues, en la organización y activación autónomas de la cooperación socialterritorial, fundada en la necesidad histórica de un status vivendi común que armonice todas las oposiciones de intereses dentro de una zona geográfica, la cual, en tanto exista un Estado mundial, aparece delimitada por otros grupos territoriales de dominación de naturaleza semejante. Madson (1979, p. 133) afirma que "a justiça é o fim de todo governo".

${ }^{7}$ O Papa João XXIII define bem comum como "o conjunto de todas as condições de vida social que consintam e favoreçam o desenvolvimento integral da personalidade humana" (Dallari, 2001, p. 107).
} 
Essa definição, para melhor servir aos propósitos deste trabalho, deve ser confrontada com a definição sociológica de Weber e com as críticas de Schumpeter à idéia de bem comum, e de Marx ao próprio Estado.

Segundo Weber (1999, p. 525), como o Estado apresenta inúmeros fins, ele só pode ser definido por seu meio peculiar de agir ${ }^{8}$, o qual o distingue de todos os outros agrupamentos políticos ("o uso da coação física"): trata-se de "comunidade humana que, dentro de determinado território - este, o ‘território', faz parte da qualidade característica reclama para si (com êxito) o monopólio da coação física legítima"9.

De acordo com Schumpeter (1961, p. 306 - 308), não há como determinar de maneira racional e inequívoca o que é o bem comum, pois "para diferentes indivíduos e grupos, o bem comum provavelmente significará coisas muito diversas", o que também inviabilizaria a existência de uma "vontade geral", fundamento da doutrina clássica da democracia.

Já para Marx e Engels (2005, p. 42), “o Executivo no Estado moderno não é senão um comitê para gerir os negócios comuns de toda a classe burguesa". Portanto, como assinala Bobbio $(1998,164)$, na concepção desses autores, o fim do Estado "não é o bem comum, mas o bem da classe dominante, o bem particular de quem governa”. Essa concepção negativa de Marx sobre o Estado decorre do fato de compreendê-lo como "simples superestrutura que reflete o estado das relações sociais determinadas pela base econômica", servindo à "classe dominante para manter o seu domínio"10.

\footnotetext{
${ }^{8}$ Weber (1999, p. 525) explica que, “do ponto de vista da consideração sociológica, uma associação "política", e particularmente um "Estado", não pode ser definida pelo conteúdo daquilo que faz. Não há quase nenhuma tarefa que alguma associação política, em algum momento, não tivesse tomado em suas mãos, mas, por outro lado, também não há nenhuma da qual se poderia dizer que tivesse sido própria, em todos os momentos e exclusivamente, daquelas associações que se chamam política (ou hoje: Estados) ou que são historicamente as precursoras do Estado moderno. Ao contrário, somente se pode, afinal, definir sociologicamente o Estado moderno por um meio específico que lhe é próprio, como também a toda associação política: o da coação física. Assim, o Estado consiste em uma "relação de dominação de homens sobre homens, apoiada no meio de coação legítima (quer dizer, considerada legítima)". Portanto, "as pessoas dominadas têm que se submeter à autoridade invocada pelas que dominam no momento dado" para que o Estado se mantenha. O fundamento moderno da legitimidade, segundo Weber (1999, p. 526 - 527) é a legalidade, ou seja, a crença na validade de regras racionalmente criadas. Para que a dominação seja exercida, além da legitimidade, são necessários meios materiais, os quais se encontram no quadro de pessoal e nos recursos materiais administrativos.

${ }^{9}$ A partir desse conceito, Weber $(1999$, p. 526) define a política como "tentativa de participar no poder ou de influenciar a distribuição do poder, seja entre vários Estados, seja dentro de um Estado entre os grupos de pessoas que abrange".

${ }^{10}$ Marx (2003, p. 5) sintetiza assim esta concepção: “na produção social da sua existência, os homens estabelecem relações determinadas, necessárias, independentes da sua vontade, relações de produção que correspondem a um determinado grau de desenvolvimento das forças produtivas materiais. $\mathrm{O}$ conjunto destas relações de produção constitui a estrutura econômica da sociedade, a base concreta a qual se eleva uma superestrutura jurídica e política e à qual correspondem determinadas formas de consciência social. O modo de produção da vida material condiciona o desenvolvimento da vida social, política e intelectual em geral.
} 
De fato, como assinala Weber, o uso da força é o modo peculiar de agir do Estado, porém este uso deve ocorrer segundo e por meio do direito ${ }^{11}$, pois, em caso contrário, o que se terá é o exercício de um poder arbitrário.

Da mesma maneira, é necessário reconhecer que não é possível determinar precisamente o que é o bem comum, porém existem parâmetros historicamente construídos que indicam o ideal a ser buscado: os direitos humanos fundamentais. Quanto à visão negativa de Marx, pondera-se que o Estado é determinado pela base econômica, mas, como se verá adiante, também ajuda a determiná-la. Além disso, estar a serviço dos interesses da classe dominante não é uma característica necessária do Estado, mas decorrência de uma forma concreta de exercício do poder político que contraria seu dever-ser.

Assim sendo, conclui-se que o poder exercido no âmbito do Estado é simultaneamente político e jurídico, tendo como finalidade a realização do bem comum, o que depende do efetivo controle democrático sobre os poderes político e econômico. Em caso contrário, o Estado estará a serviço somente dos detentores do poder e seu exercício será ilegítimo.

Mas o que define o exercício do poder como legítimo ou ilegítimo?

Weber (2006, p. 61) aponta a existência de três fundamentos para a legitimidade ao longo da história: o poder tradicional, decorrente dos costumes sacralizados e do hábito dos homens em respeitá-los; o poder carismático, baseado no reconhecimento de qualidades extraordinárias do indivíduo que dirige o Estado; e o poder racional-legal.

Discutir-se-á a legitimidade racional-legal, que é a existente no Estado de Direito, fruto das Revoluções Liberais que marcaram o fim do poder pessoal e o início da aceitação do procedimento de elaboração das normas e da manifestação da vontade popular como fundamentos do poder (FARIA, 1976, p. 83 - 86).

A dominação ${ }^{12}$ legitimada pela legalidade (legitimidade racional-formal) se fundamenta na idéia de que todo direito consiste num conjunto de regras abstratas, posto

\footnotetext{
Não é a consciência dos homens que determina o seu ser; é o seu ser social que, inversamente, determina a sua consciência. Em certo estágio de desenvolvimento, as forças produtivas materiais da sociedade entram em contradição com as relações de propriedade no seio das quais se tinham movido até então. De formas de desenvolvimento das forças produtivas, estas relações transformam-se no seu entrave. Surge então uma época de revolução social. A transformação da base econômica altera, mais ou menos rapidamente, toda a imensa superestrutura".

${ }^{11}$ Cf. DALLARI, 2001, p. $113-114$.

12 Dominação, segundo Weber (1964, 1964, p. 170), consiste na "probabilidad de encontrar obediencia dentro de un grupo determinado para mandatos específicos (o para toda clase de mandatos)", requerendo-se, ainda um mínimo de vontade e interesse em obedecer.
} 
de maneira racional e intencional, com a pretensão de ser respeitado por todos, inclusive pelo Chefe de Estado e demais autoridades, de maneira que todos obedecem ao direito e não à pessoa da autoridade que o estatuiu (WEBER, 1964, p. 173 - 174).

A legitimidade baseada na racionalidade formal parte do pressuposto segundo o qual é impossível se chegar à verdade e à justiça absolutas, pois os fins almejados pelo poder são relativos e plurais, além de que o conteúdo das leis varia constantemente. Assim, não sendo possível legitimar materialmente o poder dos governados, restariam somente dois métodos formais de legitimação: o procedimento racional de formação da vontade estatal estabelecido por lei ${ }^{13}$ e o consentimento dos governados (FARIA, 1982, p. 19 - 21).

O consentimento, na democracia representativa, é demonstrado pela eleição dos representantes políticos ou pela mobilização popular apoiando um sistema constitucional ou de governo, o que traz consigo a exigência da participação do povo no processo eleitoral, bem como da existência de outros mecanismos institucionalizados ou espontâneos por meio dos quais possa expressar sua aprovação ou reprovação (BEETHAM, 1991, p.131 - 132).

Entretanto, a legitimidade não pode ser concebida de forma axiologicamente neutra $^{14}$, e a obtenção do consentimento não pode ser considerada a única condição do processo de legitimação. Em primeiro lugar, porque o consenso entre os cidadãos se mostra difícil na moderna sociedade de massas, caracterizada pela pluralidade de idéias e interesses e pelo predomínio do dissenso ${ }^{15}$. Em segundo lugar, como o consentimento pode ser tanto espontâneo como criado artificialmente, corre-se o risco de se aceitar como legítimo um regime político simplesmente pelo fato de se conseguir conservar o poder e fazer com que as decisões sejam cumpridas durante algum tempo, independentemente de isto ocorrer por métodos democráticos ou autoritários (coerção, supressão da participação

13 Regras procedimentais normatizam: o acesso; o exercício; a organização e a distribuição do poder (BEETHAM, 1991, p. 39). Faria (1982, p. 19 - 20) aponta as seguintes características da legitimação racional-legal: “1) qualquer norma pode ser obedecida por todos os que estão sujeitos à autoridade da comunidade política; 2) o direito, como um todo, constitui um sistema de regras abstratas resultante de um estatuto; a administração da justiça consiste na aplicação dessas regras a casos particulares; a própria administração governamental está igualmente presa às regras de direito, as quais acabam sendo operadas na conformidade a princípios de formulação geral - aprovadas ou, ao menos, aceitas pela comunidade; 3) as pessoas que ocupam posições de autoridade não são governantes soberanos, mas, sim, superiores que, temporariamente, exercem um cargo, em cuja virtude possuem autoridade limitada; 4) as pessoas que obedecem à autoridade legalmente constituída, fazem-no em caráter de cidadãos, não de súditos, e obedecem à lei, não ao funcionário que a impõe".

${ }^{14}$ Nesse sentido, Bonavides (2004, p. 33 - 51) aponta o processo de "despolitização ou de neutralização" que o conceito de legitimidade vem sofrendo, de maneira a torná-lo "indiferente a valores, vazio e, por conseqüência, inócuo", mediante sua redução exclusivamente a procedimentos, à formalidade.

${ }^{15}$ Como a legitimidade depende do consenso social, mas a sociedade é caracterizada pelo dissenso, diante das divergências, é necessário garantir o respeito pelas minorias discordantes, como o faz a Constituição norte-americana (FARIA, 1976, p. 60). 
política dos divergentes, formação da opinião pública por meio da propaganda oficial) ${ }^{16}$ (FARIA, 1976, p. 56 - 57; p. 92 - 100).

Além disso, o próprio procedimento racional de formação da vontade estatal apresenta limitações e contradições. Primeiramente, como o que legitima uma determinada norma é o procedimento pelo qual ela foi elaborada e se encontra previsto em outra norma, e assim, sucessivamente, haverá sempre uma decisão primeira que estabelece a legitimidade de todas as outras, de maneira que essa decisão pode se confundir com a efetividade do poder, ou seja, ao invés de encontrar a legitimidade em uma norma superior, a decisão será legítima simplesmente pelo fato de ser obedecida. Em segundo lugar, não se distingue claramente a aceitação de uma decisão da aceitação de suas premissas, correndose o risco de se aceitar determinada premissa legal, mas não a decisão concreta efetivamente tomada, a qual não pôde ser especificada antecipadamente na lei (FARIA, 1982, p. $21-22)$.

Como assinala Comparato (2006, p. 595), a concepção racional-formal de Weber ${ }^{17}$ sobre a legitimidade a reduz a "puro fato sociológico, que nada diz quanto ao seu valor ético" e confunde "legitimidade política com a pura legalidade formal."18

Portanto, para que o exercício do poder seja legítimo, devem ser atendidos simultaneamente requisitos formais e materiais ${ }^{19}$.

Nesse sentido, Comparato (2006, p. 593 - 594) afirma que a legitimidade do poder exige, por um lado, que ele esteja em harmonia "com seu fundamento ético" e, por outro, que os governados aprovem os que detêm o poder ${ }^{20}$.

\footnotetext{
${ }^{16}$ Nesse sentido, Levi (1995, p. 678 - 679) assevera que o simples consenso não é suficiente para assegurar a legitimidade, pois ele pode ser manipulado por aqueles que detêm o poder. Portanto, a "legitimidade do Estado é uma situação nunca plenamente concretizada na história, a não ser como aspiração, e que um Estado será mais ou menos legítimo na medida em que torna real o valor de um consenso livremente manifestado por parte de uma comunidade de homens autônomos e conscientes, isto é, na medida em que consegue se aproximar à idéia-limite da eliminação do poder e da ideologia nas relações sociais".

${ }^{17}$ Weber fundamenta a legitimidade na legalidade do exercício do poder. De acordo com sua concepção, "a dominação legal-racional apresenta um caráter racional e tem por fundamento a crença na validade dos regulamentos estabelecidos racionalmente - e dentre eles sobressai a constituição - e na legitimidade dos chefes designados nos termos da lei. Em outras palavras, o poder é legítimo pelo simples fato de ser legal" (Faria, 1976, p. $81-82$ ).

${ }^{18}$ Faria $(1976$, p. 80) afirma que a legitimidade não se confunde com a legalidade, pois o poder é legítimo quando seus detentores têm "um título que justifique sua dominação", e é legal quanto seu exercício se dá "em conformidade com as leis estabelecidas". Comparato (2005, p. 556) assevera que "poder ilegítimo, embora legal e efetivo, será sempre marcado de bastardia; para sua defesa em momentos de crise só poderá contar com as suas próprias forças e nunca com a adesão dos comandados." E continua: "sem dúvida, a transformação da força em direito é uma tendência insopitável de todo detentor do poder, não por razões de ordem ética, mas essencialmente prática". E conclui: "a simples legalização da força não a legitima na consciência dos comandados. Eis porque a questão da legitimidade não é suscitada pelos que detêm o poder, mas pelos que se lhe submetem, ou aspiram possuí-lo".

${ }^{19}$ Cf. BONAVIDES, 2004, p. 280.
} 
Assim sendo, a proteção dos direitos humanos ${ }^{21}$ e a soberania popular são, respectivamente, o fundamento material e o formal da legitimidade do poder no Estado Democrático de Direito (COMPARATO, 2006, p. $603-606)^{22}$.

Evidentemente, o atendimento dos requisitos materiais e formais de legitimação do poder enfrenta grandes dificuldades, como: concentração de poder no Estado; impacto de variadas forças externas que o Estado não pode controlar; dificuldade de se efetivar e sustentar o princípio universalmente consagrado da soberania popular pelas formas institucionais; objetivos contraditórios dos sistemas político e econômico (o primeiro deve buscar a satisfação dos interesses gerais, e segundo, a satisfação de interesses particulares); inexistência de um critério incontestável sobre a melhor maneira para se realizar o interesse geral, bem como para defini-lo (BEETHAN, 991, p. 117; p. 135; p. 176 - 178).

Nos países em desenvolvimento (ou subdesenvolvidos) tais dificuldades são ainda maiores devido à estrutura social paternalista e à incapacidade do Estado de atender às demandas políticas (BEETHAM, 1991, p.171 - 172).

Não obstante essas últimas considerações, no século XXI só podem ser considerados legítimos regimes políticos que adotem integralmente o princípio republicano e o democrático, os quais definem qual a finalidade e quem deve exercer o "poder político supremo" em qualquer organização política (COMPARATO, 2006, p. 615).

Em síntese, a legitimação democrática do poder político requer o atendimento de requisitos formais (aprovação dos cidadãos aos que detêm o poder, livremente demonstrada por meio da eleição de representantes e de outros mecanismos (inclusive diretos) de controle democrático do poder do Estado, e respeito aos procedimentos racionais de formação da vontade estatal legalmente estabelecidos) e materiais (proteção dos direitos humanos).

Assim sendo, quando se utiliza a expressão "poder político" nesta pesquisa, está se referindo à espécie do gênero "poder" exercido no âmbito do Estado, ou seja: trata-se da capacidade de o Estado, por meio de normas jurídicas e da força submetida ao direito,

\footnotetext{
${ }^{20}$ Cohen (1999, p. 185) afirma que a legitimidade política democrática pressupõe que a autorização para o exercício do poder estatal seja dada por decisões coletivas tomadas pelos membros da sociedade em situação de igualdade.

${ }^{21}$ Segundo Ferrajoli (2006, p. 813) “o Estado é um meio, legitimado unicamente pelo fim de garantir os direitos fundamentais do cidadão, e politicamente ilegítimo se não os garante, ou pior, se ele mesmo os viola".

${ }^{22}$ Essas idéias, de certa forma, já aparecem em John Locke e Jean-Jacques Rousseau, bem como na "Declaração dos Representantes dos Estados Unidos da América, reunidos em Congresso Geral, datada de 4 de julho de 1776", na "Declaração de Direitos (Bill of Rights) da Virgínia, votada em 12 de junho de 1776", e na "Declaração dos Direitos do Homem e do Cidadão, votada pela Assembléia Nacional Francesa, em 4 de agosto de 1789” (COMPARATO, 2006, p. 603 - 606).
} 
cumprir seu fim que é a realização dos direitos fundamentais de povo situado em um determinado território. Essa capacidade, dialeticamente, é determinada e participa da determinação da base econômica, enfrenta tendências inatas ao abuso e estar a serviço do poder econômico, às quais deve se contrapor o controle democrático, e precisa constantemente, se legitimar para se manter, o que depende do atendimento simultâneo de requisitos formais e materiais, tarefa diante da qual se apresentam grandes dificuldades.

Precisado o entendimento adotado para o conceito de poder político, passa-se à discussão do problema do controle do poder político no Estado Democrático de Direito.

\subsubsection{Controle do Poder Político no Estado Democrático de Direito.}

O Estado Democrático de Direito corresponde à última etapa do desenvolvimento histórico da democracia moderna, o qual se inicia com a luta empreendida pelo movimento liberal ${ }^{23}$ contra o Estado Absolutista e os privilégios feudais. ${ }^{24}$ Nessa forma de Estado não havia a preocupação com o controle democrático do poder, pois o príncipe soberano detinha o poder absoluto. Tal preocupação só começa a existir com o advento do Estado Liberal de Direito.

Mill (1983, p. 36 - 43) já apontava que a comunidade não deveria entregar a direção do Estado toda para os governantes, defendendo que a comunidade inteira deve atuar como controladora suprema da vida social, reservando-se aos cidadãos o direito de, "pelo menos acidentalmente", participar de forma real do governo. Para fundamentar essa tese, aponta que os "direitos e interesses de todos ou de cada um" só são garantidos e devidamente considerados se tiverem a possibilidade permanente de expressá-los e defendê-los. Além disso, assinala que "a prosperidade geral atinge maior elevação e difunde-se mais amplamente na proporção do volume e variedade das energias pessoais interessadas em promovê-la”. Por essas razões, afirma a superioridade do governo popular, o qual, além de tudo, é o mais propício para formar o caráter humano de tipo ativo e que

\footnotetext{
23 "O Liberalismo defendia a proteção dos direitos naturais, dentre os quais se destaca o de propriedade, e o 'primado do indivíduo sobre o Estado', que era visto como o "grande inimigo da liberdade individual". A teoria apresentou o significado prático da subordinação da atividade política à econômica. A doutrina assinalava a importância da insegurança e do risco da escassez como formas de motivar os indivíduos ao trabalho. Entretanto, após sua consolidação, percebeu-se que a segurança e a escassez não derivavam da natureza, mas sim dos arranjos sociais criados pelos homens, provocando desespero e um sentimento de impotência na classe operária. Tais idéias, em suas origens, cumpriram um papel transformador, porém, em meados do século XIX, as mudanças políticas e econômicas pretendidas pelos liberais estavam consolidadas, e o liberalismo passou a atuar como uma justificação do status-quo" (DEWEY, 1970, p. 17 - 20; 41; 63 64).

${ }^{24}$ Em um governo despótico, o povo é totalmente passivo, não participando das decisões que dizem respeito à coletividade (MILL, 1983, p. 35).
} 
"luta contra os males" ao invés de suportá-los, o que não se "dobra às circunstâncias", mas "se esforça por dobrá-las".

O Estado Liberal de Direito foi fruto da ascensão social da burguesia e das Revoluções Liberais Burguesas dos séculos XVII e XVIII, as quais, por sua vez, foram impulsionadas pelas novas estruturas econômicas que se organizaram a partir da Revolução Industrial. $^{25}$

Os liberais burgueses consideravam o Estado Absolutista como o grande inimigo da liberdade. Porém, entendiam que a liberdade absoluta era incompatível com a vida em sociedade e consideravam a organização estatal necessária para garantir a ordem. Assim, desenvolveu-se a teoria do Estado Liberal, o qual tem a liberdade como valor fundamental e como objetivo a sua proteção, procurando transformar o Estado de uma ameaça em seu defensor, mediante a construção de um arcabouço institucional que limitasse seu poder por meio da sua divisão, das instituições representativas e dos direitos expressos em Declarações e Constituições ${ }^{26}$ (FERREIRA FILHO, 1988, p. 1 - 2; p. 16 $18)$.

O Estado Liberal ${ }^{27}$ deveria assegurar o livre mercado e a proteção dos cidadãos contra abusos do poder político. Para tanto, suas funções deveriam se limitar ao mínimo necessário para a preservação da ordem, da segurança interna e externa e da propriedade, deixando-se todo o campo restante para a liberdade dos indivíduos. ${ }^{28}$

Tal modelo de Estado permitiu dois momentos de prosperidade e de crescimento econômico na Europa, antes e depois da Primeira Guerra Mundial. Entretanto, demonstrou ser incapaz de "evitar crises de desequilíbrios cíclicos" e provocou uma “crescente concentração de riqueza no topo da pirâmide social, em detrimento das bases, gerando perigosas tensões que puseram em risco a estabilidade do regime e as próprias

\footnotetext{
${ }^{25}$ Cf. BOBBIO, 1990, p. 22 e PINTO FERREIRA, 1995, p. 85.

${ }^{26}$ No Estado Liberal de Direito, a lei só poderia emanar do Poder Legislativo e encontrava limites nos direitos individuais e na supremacia da Constituição. Além disso, as próprias leis e o Estado se submetiam ao controle jurídico e os governantes passaram a ser responsabilizados por seus atos. Cf. FERREIRA FILHO, 1988, p. 25 - 33, DÍAZ 1973 p. 15, LAFER (Prefácio, in BOBBIO), p. 17 e BASTOS, 1988, p. 136 - 137. Diaz (1973, p. 29) aponta quatro características fundamentais do Estado de Direito: "a) Império da lei: lei como expressão da vontade geral. b) Divisão de poderes: legislativo, executivo e judiciário. c) Legalidade da Administração Pública: atuação segundo a lei e suficiente controle judicial. d) Direitos e liberdades fundamentais: garantia jurídico-formal e efetiva realização material".

${ }^{27}$ Assinala-se que não se pode confundir o Estado Liberal de Direito com o Estado Democrático, pois a participação política nas sociedades em que foi implantado era restrita às "classes possuidoras". Da mesma forma, um Estado Democrático não é necessariamente liberal, pelo contrário, pois foi a ampliação do sufrágio fator determinante para a crise do Estado Liberal (BOBBIO, 1990, p. 7 - 8). Cf. BASTOS, 1988, p. 201.

${ }^{28}$ Cf. BOBBIO, 1990, p. 18 - 20 e MACPHERSON, 1978, p. 39.
} 
instituições democráticas", do que resultou, inclusive a "emergência dos modelos leninista e fascista" (JAGUARIBE, 1992, p. 11).

Burdeaus (1975, p. 9 - 18) pondera que, ignorando-se as diferenças existentes entre os indivíduos e as classes sociais, a compreensão de liberdade como autonomia ("ausência de constrangimento, pelo sentimento de uma independência quer física quer espiritual") e de democracia como um meio de garanti-la, na prática, o Estado Liberal servia para assegurar a permanência do domínio da burguesia, pois "para a imensa massa dos seres humanos, a liberdade concebida como uma qualidade inerente à sua natureza é apenas uma prerrogativa estéril desde o momento em que eles não estão em condições de fruir efectivamente dela" 29 . Portanto, a democracia não pode se limitar ao "regime político destinado a garantir aos indivíduos o gozo das liberdades que possuem”, pois deve representar "uma organização do poder governamental com vista a assegurar-lhes o exercício das liberdades que ainda não têm"30.

A igualdade era outro valor do Estado Liberal. Porém, tratava-se de uma igualdade meramente jurídica entre cidadãos abstratamente considerados, contrastando com a desigualdade sócio-econômica (não havia garantia de direitos e liberdades de fato para não proprietários) e com a realidade política de dominação de classe (os cidadãos se dividiam em ativos e passivos, sendo os últimos afastados das decisões políticas em função da renda inferior à dos primeiros). ${ }^{31}$

Ressalta-se que, apesar de os direitos civis e políticos já estarem consagrados naquele momento, apresentavam-se frágeis para os seguimentos mais pobres da comunidade como conseqüência da desigualdade social e das dificuldades econômicas (MARSHAL, 1978, p. $87-88$ ).

Comparato (2006, p. 644) assevera que o sistema político vigente na época representou, pelo menos no início, uma completa inversão funcional. O mecanismo da representação popular, que deu origem à democracia formal,

\footnotetext{
${ }^{29}$ Diante disso, o autor (1975, p. 14) indaga: "que importa que o homem seja livre de pensar se a expressão da sua opinião o expõe a um ostracismo social, que seja livre de discutir as condições de seu trabalho se sua situação econômica o obriga a curvar-se à lei do empregador, que seja livre de organizar os seus ócios se a necessidade do pão quotidiano absorve todo o seu tempo, que seja livre de desenvolver a sua personalidade pela cultura e pela contemplação de um universo oferecido a todos se lhe falta materialmente o mínimo vital $\ldots ? "$

30 Deve-se distinguir a idéia de liberdade para o cidadão abstrato e para o homem concreto: "a liberdade do cidadão é um atributo de sua pessoa; incondicional e metafísica, adere-lhe onde quer que ele esteja. Ela não tem de ser criada, mas apenas reconhecida. O que ela exige é que a ordem social estabelecida lhe não traga entraves. O homem situado, pelo contrário, espera a libertação, ou seja, uma alteração das relações sociais que lhe permita usufruir de uma liberdade que ainda não tem" (BURDEAUS, 1975, p. 22)

31 Cf. COMPARATO, 2005, p. 34, DIAZ, 1973, p. 27, PINTO FERREIRA, 1995, p. 85 - 87; MACPHERSON, 1978, p. 49.
} 
constituiu, na realidade, um claro impedimento à soberania do povo. Ele serviu para encobrir, sob uma aparência democrática, a consolidação do sistema oligárquico, ou seja, o regime da soberania dos ricos.

Para evitar contestação a tal forma de organização política, a elite capitalista procurava (e procura) desestimular a participação política da população, chegando a considerar a política um "mal necessário",32, mediante a construção ideológica segundo a qual a liberdade, na sua concepção moderna, não significa participação ativa na vida pública, mas sim a não interferência do Estado nas atividades privadas; os cidadãos não deveriam se preocupar com os assuntos públicos, deixando-os por conta de seus representantes, a fim de melhor poderem se dedicar aos seus negócios privados (COMPARATO, 2006, p. 649) ${ }^{33}$.

$\mathrm{Na}$ verdade, desde a Grécia Antiga se questionava a aptidão do povo para exercer a soberania política. Afirmava-se que a falta de instrução dos pobres e o fato de terem que trabalhar para sobreviver (não lhes restando tempo para se dedicar à atividade política) os desqualificava para tal tarefa. Entretanto, a essas razões foi acrescentada outra na modernidade: "a miséria embrutecedora a que são condenadas populações inteiras dos países subdesenvolvidos, por força da expansão capitalista" (COMPARATO, 2006, p. 656 $-657)$.

A situação de exploração e miserabilidade em que viviam os não proprietários desencadeou lutas dos movimentos sociais, no século XIX e início do século XX, por direitos e melhores condições de vida. Dessas lutas, somadas ao processo de universalização do sufrágio, à demonstração das insuficiências e deficiências do liberalismo (por exemplo, pela Doutrina Social da Igreja Católica), às crises do Capitalismo que exigiam maior intervenção do Estado na economia e ao temor dos burgueses de que as Revoluções Socialistas pudessem se expandir, surge uma nova forma de organização política: o Estado Social, o qual assume diferentes e mais amplas funções,

\footnotetext{
32 Nesse sentido, o Comparato (2006, p. 649) acrescenta: “o ideal, mal e mal encoberto pelos líderes capitalistas, é substituir os políticos por um corpo de gerentes especializados, tal como se faz nas grandes empresas".

33 O citado autor $(2006$, p. 649 - 650) pondera que "na verdade, essa proclamada virtude de uma vida inteiramente dedicada a assuntos privados é a pior forma de fazer política. É a divisão do que deveria ser uma comunidade em duas esferas - a sociedade civil e o aparelho estatal -, com a aceitação incontestada da soberania oligárquica e da irresponsabilidade dos governantes. O povo ateniense foi freqüentemente censurado pela sua leviandade de se deixar iludir pelos demagogos. Mas as massas modernas nem se dão conta de como se deixam facilmente enganar pela propaganda ideológica e a publicidade comercial, maciçamente instrumentadas pelos meios de comunicação coletiva, a serviço dos interesses oligárquicos. $\mathrm{O}$ que em Atenas era tido como reles demagogia passou a ser apresentado como a garantia integral das liberdades democráticas.
} 
procurando corrigir o individualismo clássico liberal pela afirmação dos direitos sociais, e compatibilizar o Capitalismo com a realização do bem-estar de todos. ${ }^{34}$

No Estado Social, passou-se a exigir não somente a igualdade formal perante a lei, mas também a igualdade substancial ${ }^{35}$. O Estado deveria agir, pois os direitos deixaram de ser faculdades a serem protegidas, passando a ser necessidades a serem atendidas. Objetivava-se a libertação do indivíduo de todas as formas de opressão, não só política, mas também econômica e social, ou seja: da situação de exclusão e miséria, das condições desumanas de trabalho e da desigualdade social $^{36}$. Nesse contexto, a participação política não cumpre o papel de impedir o arbítrio e assegurar a autonomia, mas sim reformar estruturalmente a sociedade. Diante disso, a democracia se expande tanto no plano estatal (pelo aumento da pressão do povo sobre os governantes e a consequente ampliação do controle destes sobre as estruturas econômicas e sociais), como em outros campos de atividade (por exemplo, a participação dos trabalhadores na gestão das empresas). Assim, ocorre uma politização de toda a sociedade ${ }^{37}$, pois as massas perdem a esperança de atingir a felicidade por meio de seu esforço pessoal no livre mercado, visto que as melhorias obtidas nas suas condições de vida decorreram da política. ${ }^{38}$

Nesse contexto, segundo Bercovici (2000, p. 29), o "Estado deixa de ser apenas o poder soberano para, também, tornar-se o principal responsável pelo direito à vida, concretizado por meio dos direitos sociais". Com isso, "governar passou a não ser mais a gerência de fatos conjunturais, mas também, e sobretudo, o planejamento do futuro, com o estabelecimento de políticas de médio e longo prazo".

Bercovici (2000, p. 32 - 33) salienta que "em nenhum lugar do mundo, o Estado Social é uma realidade acabada, mas está em constante realização", sendo que, "a concretização do Estado Social está ligada à idéia de transformação global da sociedade". No caso brasileiro, pode-se afirmar que há um Estado Social no sentido de um Estado

\footnotetext{
${ }^{34}$ Cf. SILVA, 2001, p. 119.

${ }^{35}$ Bercovici (2000, p. 31) salienta que "o objetivo primordial do Estado Social, assim, torna-se a busca da igualdade, com a garantia da liberdade. O Estado não se limita mais a promover a igualdade formal, jurídica. A igualdade procurada é a igualdade material, não mais perante a lei, mas através da lei. A igualdade não limita a liberdade. O que o Estado busca garantir é a igualdade de oportunidades, o que implica na liberdade, justificando a intervenção estatal".

${ }^{36}$ Nesse momento histórico, os direitos sociais assumiram o objetivo não só de garantir condições de vida minimamente decentes para os pobres, mas também de modificar "o padrão total da desigualdade social" (MARSHAL, 1978, p. 88 - 89).

${ }^{37}$ Essa politização total da sociedade, entretanto, como assinala Burdeaus (1975, p. 58 - 59) apresenta o risco de comprometer as liberdades individuais.

${ }^{38}$ Cf. BURDEAUS, 1975, p. 40 - 57, FARIA, 1982, p. 110 - 114, PINTO FERREIRA, 1995, p. 92.
} 
intervencionista, mas não que exista um Estado social em sentido estrito ${ }^{39}$, ou seja, que garanta o bem-estar ${ }^{40}$, mediante um "amplo sistema de seguridade e assistência social", podendo-se considerar, no máximo, segundo a Constituição de 1988, que se trata de um Estado Social em construção.

Apesar disso, onde foi efetivamente implantado, o Estado Social possibilitou uma melhoria dos níveis de vida dos setores desfavorecidos da sociedade. Entretanto, nos anos oitenta, esse modelo entrou em crise, devido aos seguintes fatores: crescimento excessivo da burocracia, grandes déficits fiscais, diminuição da rentabilidade do capital perante os salários diretos e indiretos (benefícios sociais) e incapacidade de exercer a regulação, diante da internacionalização dos mercados e da transnacionalização da produção $^{41}$

A crítica ao Estado Social foi feita pelo movimento neoliberal ${ }^{42}$, que propôs um novo modelo por meio do qual o Estado atua como regulador da economia e promove serviços básicos, mas não exerce atividades empresariais e transfere para as organizações da sociedade muitos serviços públicos (JAGUARIBE, 1992, p. 12 - 13).

Comparato (2006, p. 607) relata que, nesse período, passou-se a sustentar que “os gastos públicos com saúde, educação, previdência e assistência social são um processo altamente irracional, sob o aspecto da coerência administrativa e da estabilidade fiscal". Entretanto, ele pondera que

em lugar de se dizer que o aumento dos gastos públicos com políticas sociais solapa o capitalismo, alardeou-se que tais despesas, pelos seus efeitos inflacionários, constituíam uma séria ameaça ao regime democrático. Essa

\footnotetext{
${ }^{39}$ Cf. SANTOS, 2000, p. 17. O autor (2000, p. 96) ressalta que em países semi-periféricos como Portugal e o Brasil, "não foi possível erradicar o clientelismo e o Estado não se comprometeu com o bem-estar das classes populares a ponto de se poder constituir num Estado-Providência"

${ }_{40}$ Embora tenham apresentado um grande crescimento econômico nas décadas de 60 e 70 do século XX, países latino-americanos, como México e Brasil, não alcançaram "nem a universalização da educação de base, nem a erradicação da miséria, nem, finalmente, a concessão de níveis razoáveis de vida para a maioria de suas populações" (JAGUARIBE, 1992, p. 14 - 15).

${ }^{41}$ Cf. JAGUARIBE, 1992, p. 12 e SANTOS, 2000, p. 248.

${ }^{42}$ Bobbio (1990, p. 87; 92 - 95) define neoliberalismo como "uma doutrina econômica conseqüente, da qual o liberalismo político é apenas um modo de realização, nem sempre necessário; ou, em outros termos, uma defesa intransigente da liberdade econômica, da qual a liberdade política é apenas um corolário". Os neoliberais muitas vezes apontam a ingovernabilidade da democracia, devido à sua incapacidade de dominar adequadamente os conflitos sociais, pois o número de demandas provenientes da sociedade é muito grande na democracia, ao mesmo tempo em que a dificuldade de dar respostas a ela é muito maior do que em regimes autocráticos, devido à lentidão do processo de deliberação (demanda fácil e resposta difícil). Disso resulta a defesa do reforço do Poder Executivo e da limitação da esfera das decisões tomadas por meio da regra da maioria, característica da democracia, chegando-se a propor, inclusive, a limitação constitucional do "poder econômico e fiscal do parlamento, de modo a impedir que a resposta política à demanda social acabe por produzir um excesso de despesa pública com respeito aos recursos do país".
} 
ameaça consistiria em que o Estado Social carece intrinsecamente de 'governabilidade': os governos já não contariam com os recursos financeiros indispensáveis para fazer atuar os serviços públicos básicos. Em suma, o atendimento dos direitos econômicos e sociais dos cidadãos conduziria o Estado à falência.

Hayek (1983, p. 313 - 314), por exemplo, afirma que os direitos assegurados pelo Estado de Bem-Estar Social ameaçariam a liberdade e a democracia, pois, "embora apresentadas como mera prestação de serviços, representam na verdade um exercício do poder coercitivo do governo e sua realização depende do fato de o governo outorgar a si mesmo direitos exclusivos em certos campos de atividade". ${ }^{3}$

Na mesma linha, Ferreira Filho (1988, p. 39 - 49; p. 58 - 64) afirma que o Estado Social, ao longo do século XX, mudando sua missão de simples manutenção da ordem e da liberdade individual para o fornecimento a todos de "condições de vida adequadas", teria transformado o Estado de Direito em Estado Legal ${ }^{44}$. Isso porque a lei teria se tornado mero "instrumento para a realização de objetivos politicamente definidos", identificando-se o direito com o comando Estatal, independentemente de seu conteúdo estar de acordo com a justiça e se submeter a um Direito superior, bastando que houvesse uma adequação a seu procedimento formal de elaboração. Isso tudo teria enfraquecido as limitações do poder, ocorrendo fenômenos como a fragilização dos direitos fundamentais, a não submissão da Constituição a limites jurídicos anteriores, a não adaptação da divisão do poder às novas funções do Estado, o voluntarismo jurídico e a desvinculação do Direito da justiça, culminando-se na própria negação do Estado de Direito. Como alternativa, o autor propõe uma "renovação das linhas clássicas do Estado de Direito", de maneira que a lei seja "necessariamente expressão da justiça", ressaltando que não defende a tese de um

\footnotetext{
${ }^{43}$ O referido autor (1983, p. 355 - 367) critica, por exemplo, o sistema público de aposentadorias do Estado de Bem-Estar Social, pois, no seu entendimento, os idosos deveriam receber somente "sustento e assistência mínimos", e não adequados. Faz o mesmo com relação ao sistema público de saúde e ao seguro desemprego, afirmando que a crise da previdência social enfrentada por muitos países se deve ao fato de que "um aparato montado para aliviar a pobreza foi transformado em um instrumento de redistribuição de renda, redistribuição supostamente baseada num inexistente princípio de justiça social, mas na realidade, determinada por decisões tomadas ao sabor das circunstâncias", isso porque a minoria que tem mais não deveria ter que distribuir parte de sua renda para a maioria que tem menos.

${ }^{44}$ Barros (2007, p. 5), partir de uma perspectiva distinta de Ferreira Filho, também critica o "Estado de mera Legalidade", afirmando que nele "a lei é editada e aplicada sem levar em conta o resultado, ou seja, sem considerar se daí resulta uma injusta opressão dos direitos. Impera o Legalismo, a forma mais sutil de autoritarismo, na qual o espírito autoritário se encarna na própria lei. O processo legislativo atende à conveniência política do poderoso do momento, quando não é ele mesmo quem edita a norma jurídica, "provisoriamente"'.
} 
"Estado Democrático de Direito", segundo a qual deveria ocorrer "a transição para o socialismo, por meio da democracia participativa".

Observa-se, portanto, que os defensores do liberalismo costumam apontar uma “antinomia entre Estado de Direito e Estado Social”, afirmando-se que este seria contrário às liberdades individuais. Entretanto, essa antinomia se revela falsa, pois o Estado Social seria "um passo a mais na democratização do Estado", pois "com a democracia social, amplia-se a esfera democrática para a regulação dos setores econômicos, com a ordem econômica e social colocada à disposição da vontade popular, democraticamente manifestada" (BERCOVICI, 2000, p. 29 - 30).

Entretanto, mesmo juristas com posição contrária ao neoliberalismo, como Silva (2001, p. 119 - 122), criticam as ambiguidades do Estado Social, como a utilização da palavra social por diferentes regimes políticos (democracia, fascismo e nazismo) e o uso de sua roupagem para esconder uma "ditadura do grande capital". O autor também salienta que, se Estado Liberal assegurava uma igualdade "puramente formal e abstrata", o Estado Social, que foi uma tentativa de corrigir isso, "não foi capaz de assegurar a justiça social nem a autêntica participação democrática do povo no processo político". Dessa linha de crítica ao Estado Social decorre a concepção de Estado Democrático de Direito, o qual almeja a realização de uma "Justiça material",4 mediante "um processo de efetiva incorporação de todo o povo nos mecanismos do controle das decisões, e de sua real participação nos rendimentos da produção".

A proposta do Estado Democrático de Direito é muito mais radical do que a do Estado Social e também do que a do Estado Socialista: não se limita à tentativa de garantir condições mínimas de bem-estar para todos e corrigir falhas da economia de mercado, nem aceita a utilização de métodos ${ }^{46}$ personalistas e autoritários ${ }^{47}$. O Estado Democrático de Direito propõe uma transformação estrutural da sociedade pela via democrática: seu fim é a libertação do ser humano de todas as formas de opressão, inclusive assegurando-se condições econômicas e sociais para o pleno exercício de todos os direitos humanos, e a

\footnotetext{
${ }^{45}$ Barros (2007, p. 6 - 7) assinala que o Estado Democrático de Direito tem como baliza os direitos humanos e deve ser efetivado com justiça, "mas não com qualquer justiça e, sim, com a única verdadeira justiça, que é a justiça social, pois justiça anti-social é uma contradição em termos: é uma negação em si mesma".

${ }_{46}$ Dewey (1970, p. 260) salienta que "se há uma conclusão que a experiência humana inegavelmente confirma é a de que fins democráticos requerem métodos democráticos para sua realização". E acrescenta: "a democracia somente pode ser servida pela lenta e quotidiana adoção e contagiosa difusão, em cada fase de nossa vida comum, de métodos que sejam idênticos aos fins a serem alcançados".

${ }^{47}$ Nesse sentido, Silva (2001, p. 116) afirma que o "Estado Democrático de Direito reúne os princípios do Estado Democrático e do Estado de Direito, não como simples reunião formal dos respectivos elementos, porque, em verdade, revela um conceito novo que os supera, na medida em que incorpora um conceito revolucionário de transformação do status quo".
} 
construção de uma sociedade materialmente justa, pluralista e solidária; o meio para se atingir esse fim é a verdadeira soberania popular, exercida não só por meio de representantes, mas também diretamente, com uma efetiva participação da população no processo político. $^{48}$

A concepção de Estado de Direito de Ferrajoli (2006, p. 790) apresenta semelhanças com a noção de Estado Democrático de Direito até aqui apresentada. Segundo o autor, o Estado de Direito não é "simplesmente um 'Estado Legal' ou 'regulado pelas leis"”, trata-se de um modelo de Estado que, no plano formal, é subordinado a leis gerais e abstratas que disciplinam o exercício de seu poder e cuja observância é submetida ao controle do Poder Judiciário independente, e, no plano substancial, incorpora na Constituição os direitos fundamentais dos cidadãos, o que gera deveres públicos correspondentes, ou seja, vedações à lesão aos direitos de liberdade e obrigações de satisfação dos direitos sociais, garantindo-se a tutela judicial para os cidadãos em caso de violação desses direitos. Portanto, o poder do Estado é limitado pela forma e pelo conteúdo dos direitos fundamentais, sendo inválidos os atos que os violarem e podendo ser seus autores responsabilizados.

As Constituições do século XX passaram a consagrar direitos sociais que correspondem a "deveres públicos de fazer" que vinculam o Estado. A partir de então, para que o Estado seja legítimo não basta "não piorar as condições de vida dos cidadãos", mas “deve ainda melhorá-las". Entretanto, os direitos dos cidadãos a prestações positivas do Estado não dispõem das mesmas garantias de defesa e possibilidades de tutelas judiciais que os direitos de liberdade. Tal dificuldade decorre do fato de as garantias sociais exigirem prestações positivas que apresentam custos econômicos, atividades de outros sujeitos que não os próprios interessados e a edição de normas por certas autoridades que não podem facilmente ser obrigadas a editá-las (FERRAJOLI, 2006, p. 792 - 797).

Ferrajoli $(2006$, p. 797 - 798) pondera, todavia, que da mesma forma que no Estado Liberal não se pode decidir sobre tudo, no Estado social "nem sobre tudo se pode não decidir", de maneira que nem mesmo a maioria pode deixar de tomar decisões sobre questões de sobrevivência, pois a democracia política (quem decide) se subordina à democracia social (sobre o que não se pode decidir e sobre o que não se pode não decidir). Portanto, “em um sentido não formal e político, mas substancial e social de 'democracia', o Estado de direito equivale à democracia, no sentido que reflete, além da vontade da

${ }^{48}$ Cf. Silva (2001, p. $\left.121-124\right)$ e Diaz (1973, p. 17; p. 39). 
maioria, os interesses e necessidades vitais de todos". Portanto, as garantias (liberais ou sociais) exprimem "os direitos fundamentais dos cidadãos contra os poderes do Estado" e, sobretudo, "os interesses dos fracos respectivamente aos dos fortes, a tutela das minorias marginalizadas ou dissociadas em relação a maiorias integradas, as razões de baixo relativamente às razões do alto".

A estipulação de todos esses direitos apresenta uma dimensão utópica, própria dos valores, ou seja, eles nunca são "realizáveis perfeitamente ou de vez por todas", do que decorre uma "latente e estrutural ilegitimidade jurídica do Estado de direito", por não conseguir cumprir integralmente suas promessas normativas, de maneira que sua legitimidade não pode ser reconhecida em princípio, mas somente após se verificar se está cumprindo seus deveres públicos. Diante disso, mais do que ampliar os direitos, é necessário "o desenvolvimento de garantias capazes de realizá-las" e que permitam que os não atendidos questionem permanentemente o Estado e sua legitimidade (FERRAJOLI, 2006, p. $799-817)$.

Tal função garantista do direito não se refere exclusivamente aos poderes públicos, mas também aos privados (econômico, familiar etc.), os quais também tendem ao abuso, geram desigualdades entre as pessoas e representam obstáculos à liberdade e à igualdade dos cidadãos quando não regulados e submetidos ao controle democrático (FERRAJOLI, 2006, p. 857 - 861).

Ferrajoli (2006, p. 867 - 872) salienta que, além das garantias jurídicas, a realização dos direitos fundamentais exige um substrato político, social e cultural, ou seja, o sentimento, a consciência, a luta e a permanente vigilância dos cidadãos por sua concretização, a constante participação e pressão populares. Somente a constante luta pelo direito, ou seja, "seu constante exercício e sua tenaz defesa contra todo possível obstáculo, ameaça ou violação" é capaz de garantir sua efetividade. Essa luta abrange não só a defesa contra sua violação, mas também a reivindicação de novos direitos e novas formas de tutela. Os direitos são conquistados historicamente mediante processos de lutas coletivas, não são dados gratuitamente. Mediante essas lutas são afirmadas as "necessidades vitais insatisfeitas", promovendo-se mudanças na esfera do direito e da realidade concreta. Pela democracia a luta pelos direitos se desenvolve em conflitos pacíficos, "e por meio destes as transformações sociais e institucionais". Sem a possibilidade desta luta, da manifestação direta da população, há sempre o risco da degeneração da democracia em autoritarismo. 
Para a realização de seus objetivos, o Estado Democrático de Direito se vale das políticas públicas. $^{49}$

Bucci (2001, p. 236) define políticas públicas como "programas de ação governamental visando coordenar os meios à disposição do Estado e as atividades privadas, para a realização de objetivos socialmente relevantes e politicamente determinados" $" 50$.

As diretrizes e os critérios das políticas públicas são fixados pelas normas programáticas e de direitos humanos positivados nas Constituições, pelas normas infraconstitucionais (especialmente nas leis orçamentárias) e pelo nível de desenvolvimento da sociedade. Devem ser implementadas por sucessivos governos a partir de um processo democrático de planejamento e execução, mediante formas de participação direta da população (audiências públicas, orçamento-participativo, conselhos administrativos paritários de agentes públicos e agentes civis etc. $)^{51}$, o que é fundamental para evitar que se submetam aos interesses da tecnocracia, a conveniências eleitorais de interesses pessoais dos que estão no poder e à pressão dos poderosos grupos econômicos. ${ }^{52}$

Bercovici (2006, p. 144) acrescenta que

o próprio fundamento das políticas públicas é a necessidade de concretização de direitos por meio de prestações positivas do Estado, sendo o desenvolvimento nacional a principal política pública, conformando e harmonizando todas as demais. O desenvolvimento econômico e social, com a eliminação das desigualdades, pode ser considerado como a síntese dos objetivos históricos nacionais.

O Estado deve atuar por meio do planejamento, o qual "coordena, racionaliza e dá uma unidade de fins à atuação do Estado, diferenciando-se de uma intervenção conjuntural ou casuística". Trata-se de "um ato de direção política, pois determina a

49 Barros (2007a, p. 3) define políticas públicas como "diretrizes de interesse público primário, que determinam programas de ação para os governantes e indicam linhas de conduta para os governados, com vistas a ordenar e coordenar a realização de fins econômicos, sociais e culturais relevantes para o Estado Democrático de Direito".

${ }^{50}$ Bucci (2001, p. 246) afirma que "as políticas são instrumentos de ação dos governos", de maneira que a função de governar - o uso do poder coativo do Estado a serviço da coesão social - é o núcleo da idéia de política pública, redirecionando o eixo de organização do governo da lei para as políticas. As políticas são uma evolução em relação à idéia de lei em sentido formal, assim como essa foi uma evolução em relação ao government by men (governo de homens), anterior ao constitucionalismo. E é por isso que se entende que o aspecto funcional inovador de qualquer modelo de estruturação do poder político caberá justamente às políticas públicas. Cf. BUCCI, 2001, p. 248.

${ }^{51}$ A definição de uma política como pública abrange tanto seus destinatários como seus autores, de maneira que "uma política é pública quando contempla os interesses públicos, isso é, da coletividade" e, ao mesmo tempo, seja expressada por "um processo público, no sentido de aberto à participação de todos os interessados, diretos e indiretos, para a manifestação clara e transparente das posições em jogo" (BUCCI, 2001, p. 258 - 259).

${ }^{52}$ Cf. BARROS, 2007c, p.6, 2007a, p. $1-2$. 
vontade estatal por meio de um conjunto de medidas coordenadas". Ele não é "neutro", pois está "comprometido axiologicamente, tanto pela ideologia constitucional como pela busca da transformação do status quo econômico e social". Portanto, "embora tenha conteúdo técnico, é um processo político, especialmente nas sociedades que buscam a transformação das estruturas econômicas e sociais" (Bercovici, 2006, p. 145 - 146).

Por isso tudo, "o planejamento exige um Estado forte, capaz de direção e coordenação", o qual se mostra incompatível com o modelo liberal de Administração e o Direito Administrativo ainda vigente, que busca a proteção dos direitos individuais e não a “implementação dos princípios e políticas consagrados na Constituição".

A obrigação de o Estado planejar o desenvolvimento econômico está expressa no artigo 174, caput, da Constituição Federal. Bercovici (2006, p. 153 - 155) salienta que “o modelo de planejamento previsto na Constituição de 1988 visa a instituição de um sistema de planejamento com grande participação do Poder Legislativo e vinculação do plano ao orçamento e aos fins enunciados no texto constitucional", com ampla transparência e efetivo controle sobre o gasto público ${ }^{53}$.

Os dois princípios basilares para a realização dos fins do Estado Democrático de Direito são o Republicano e o Democrático.

O princípio Republicano implica: uma radical "distinção entre o interesse próprio de cada um em particular e o bem comum de todos, com a exigência de que esse se sobreponha àquele"; o reconhecimento da igualdade de todos, de maneira que diferenças biológicas e culturais sejam legitimamente respeitadas, porém não deve existir qualquer forma de privilégio; respeito pelos direitos humanos; total publicidade e transparência dos atos oficiais; o impedimento à apropriação ou ao controle particular de bens e serviços que, pela sua natureza, são comuns a todos os integrantes do corpo social."54 Além disso, é preciso, permanentemente, combater as desigualdades sociais, aperfeiçoar eticamente a comunidade e otimizar a vida em sociedade sob a orientação de três objetivos

\footnotetext{
${ }^{53} \mathrm{O}$ autor (2006, p. 155) explica que "a atividade do planejamento está prevista na Constituição (art. 174) como submetida ao princípio da legalidade. É a condição do plano enquanto lei, debatida e aprovada pelos representantes do povo, que dá o caráter democrático ao planejamento, Além disso, os governantes devem atuar obedecendo à hierarquia de prioridades e recursos fixada no plano que, obviamente, pode ser adaptado às novas circunstâncias, servindo, assim, como orientação e coordenação efetiva da política governamental, evitando o desvio de poder e o privilégio de interesses particulares na Administração. Deste modo, o planejamento é uma possibilidade de controlar a atuação do Estado, pois deve definir a direção e o ritmo que irá tomar".

${ }^{54}$ Entre esses bens e serviços podem ser citados: o genoma humano, os recursos naturais não renováveis, o conhecimento científico e tecnológico, ligado à preservação da vida ou da saúde humana, reservas florestais ou terras agrícolas, os meios de comunicação de massa, e os serviços destinados a satisfazer as necessidades fundamentais de todos (COMPARATO, 2006, p. 626 - 635).
} 
fundamentais: "o crescimento econômico sustentável, a equalização das condições básicas de vida para todos e a participação efetiva do povo nas grandes decisões políticas" (COMPARARO, 2006, p. $617-622){ }^{55}$

O meio para a realização dos fins do Estado Democrático de Direito é a democracia (ou o exercício da soberania ${ }^{56}$ popular), porém não se trata daquela concepção característica do Estado Liberal.

Macpherson (1978, p. 81 - 91) aponta que, em meados do século XX, passou a prevalecer um modelo de democracia denominado de "democracia de equilíbrio", caracterizado pelo pluralismo e pelo elitismo ${ }^{57}$. De acordo com este modelo, a democracia se reduziria a um mecanismo de governos por meio de um sistema competitivo, no qual à população caberia exclusivamente votar, pois a resolução dos problemas políticos seria uma função da elite política. Todavia, esse modelo esvazia o conteúdo valorativo da democracia e, na verdade, não se revela democrático, pois, no "mercado político", o dinheiro define em grande medida o poder de compra (financiamento de partidos ou candidatos, organização de grupos de pressão, aquisição de espaços nos meios de comunicação de massa), o que desequilibra as forças em favor dos detentores das riquezas.

\footnotetext{
${ }^{55}$ Contrariando esses objetivos republicanos, temos um exemplo claro no sistema tributário e na distribuição dos recursos orçamentários do Brasil: no aspecto tributário, o país apresenta setenta por cento de tributos indiretos, os quais são regressivos, ou seja, proporcionalmente à sua renda e patrimônio, quanto mais pobre for o indivíduo mais ele pagará e, ao contrário, quanto mais rico, menos imposto pagará. No aspecto orçamentário, no período compreendido entre 2002 e 2006, as despesas com saúde corresponderam a menos de um quarto dos gastos com a dívida pública, e as referentes à educação a pouco mais do que dez por cento deste montante. Tomando-se somente o ano de 2006, observa-se que os recursos destinados ao programa Bolsa Família representaram cinco por cento dos juros pagos aos detentores de títulos da dívida pública, e o serviço dessa dívida, que compreende além do pagamento de juros a amortização do capital, totalizou cento e cinqüienta e oito bilhões de reais, o que equivale a quase quatro vezes o denominado déficit da previdência, $o$ qual em grande parte é falso. Assim sendo, observa-se como o Estado brasileiro favorece mais aos ricos do que os pobres, contrariando os objetivos de uma verdadeira república. Para que essa situação seja alterada é preciso atribuir efetivamente a soberania à população, retirando poder das oligarquias políticas e econômicas (COMPARATO, 2007, A3).

${ }^{56}$ Foi Jean Bodin $(1530$ - 1596) o grande teórico da soberania. Segundo esse autor, "todo poder inferior é subordinado a um superior, o qual, por sua vez, se subordina a outro poder superior. No ápice deve haver um poder que não tem sobre si nenhum outro - e esse poder supremo 'summa potestas', é o poder soberano". O autor define soberania como "poder absoluto e perpétuo que é próprio do Estado" (BOBBIO, 1998, p. 95 96). Segundo Comparato (2006, p. 63), trata-se do "poder supremo da sociedade".

${ }^{57}$ Burdeaus (1975, p. 34 - 39; 71 - 75) associa ao Estado Liberal uma espécie de democracia que denomina de governada, na qual cidadãos abstratos governam e os homens reais são governados, por meio de representantes independentes da totalidade da nação. Já ao Estado Social, o autor associa a "democracia governante", na qual se concebe que o povo pode governar sem representantes. A grande dificuldade deste último modelo consiste no fato de que as tarefas atribuídas ao Estado serem tão numerosas e complexas que o povo não as consegue realizar diretamente, e nem mesmo controlá-las. Além disso, por ser marcada por conflitos e contradições, corre-se o risco de a vida política se reduzir à "luta pelo Poder" e de os governos não serem capazes de atender às aspirações populares. Um terceiro modelo, denominado de "pluralista", também corre o risco de não alcançar seus objetivos de transformação da sociedade e garantia de direitos, devido, justamente, à diversidade das visões de sociedade que entram em conflito e podem paralisar a ação da coletividade, sendo marcada por incoerências.
} 
Essa desigualdade, a pouca responsabilidade do governo perante o eleitorado e o sentimento de que "não há escolha real" no ato de votar contribuem para a "apatia política", a qual é indispensável para manter a coesão de uma sociedade caracterizada pela desigualdade socioeconômica.

O reconhecimento das limitações dos modelos liberais e da necessidade de maior participação de todos nos processos decisórios (tanto no âmbito do Estado como no setor privado) leva ao desenvolvimento da idéia de democracia como participação, sobretudo a partir dos anos setenta ${ }^{58}$ (FARIA, 1982, p. 121 - 122).

De acordo com Santos (2000, p. 98; 270 - 271), a democratização exige a incorporação política autônoma das classes populares, ou seja, livre do clientelismo, do personalismo, da corrupção e da dominação privada do Estado por grupos sociais ou por seus agentes. Além disso, o conceito de política deve sofrer uma "ampliação radical”, a fim de maneira que a democratização e a emancipação atinjam todos os campos da vida social, como o econômico, mediante a "articulação entre a democracia representativa e a democracia participativa", pois o processo democrático não pode se limitar ao ato de votar.

Bonavides afirma a superioridade da democracia direta em relação à indireta, pelo fato de esta última não ter sido capaz de resolver o problema das desigualdades, da dependência e da opressão dos povos subdesenvolvidos, e de a primeira ser a única capaz de evitar a usurpação do voto e da consciência dos cidadãos, que frequentemente ocorrem no sistema representativo ${ }^{59}$. Sua crença na viabilidade da democracia direta no século XXI também se deve aos avanços tecnológicos. Defendendo que, enquanto ela não chegar, deve-se recorrer aos instrumentos da democracia semi-direta previstos na Constituição.

\footnotetext{
${ }^{58}$ Isso se daria, por exemplo, no processo de elaboração legislativa, em que a participação popular cumpriria o papel importante de se contrapor a influência exercida por setores mais poderosos e articulados da sociedade (FARIA, 1982, p. 122 - 123). Outra visão sobre a democracia que vale ser mencionada é a de Dahl. Segundo ele, constituem aspectos fundamentais da democratização o sistema político permitir "rivalidade ou competição entre um governo e seus oponentes" e "a contínua responsividade do governo às preferências dos cidadãos considerados como politicamente iguais". Para tanto, "todos os cidadãos plenos devem ter oportunidades plenas: 1. De formular suas preferências. 2. De expressar suas preferências a seus concidadãos e ao governo através da ação individual e da coletiva. 3. De ter suas preferências igualmente consideradas na conduta do governo, ou seja, consideradas sem discriminação decorrente do conteúdo ou da fonte da preferência". Portanto, para o autor, a democratização é "formada por pelo menos duas dimensões: contestação pública e direito de participação" (DAHL, 1997, P. 25 - 29). Como, para o referido autor (1997, p. 31), nenhum sistema do mundo é plenamente democrático, ele prefere chamar os regimes "relativamente (mas incompletamente) democratizados" de "poliarquias", ou seja, "regimes que foram substancialmente popularizados e liberalizados, isto é, fortemente inclusivos e amplamente abertos à contestação pública".

59 Nesse sentido, Bonavides (2004, p. 19 - 20) salienta que "sem democracia, todas as formas de status quo que alojam, conservam e perpetuam situações de privilégio, desigualdade e discriminação tendem à imutabilidade, eternizando as mais graves injustiças sociais ou fazendo do homem, para sempre, um ente rebaixado à ignomínia da menoridade política, da ausência e do silêncio, sem voz para protesto e sem arma para o combate; objeto e não sujeito da vontade que governa; súdito e não cidadão".
} 
Para tanto, aponta a necessidade da construção de uma cultura política democrática, mediante a capacitação política do povo e a existência de amplas possibilidades de participação (BONAVIDES, 2004, p. 17 - 32).

Nesse sentido, o citado autor (2004, p. 32) salienta que "não haverá a revolução ética que tanto se preconiza de último se não vier acompanhada de uma revolução constitucional: a da legitimidade, que só a democracia direta confere ao exercício dos poderes carecentes de regeneração". E acrescenta:

uma organização institucional que não coloque os Poderes públicos - Legislativo e Executivo - da União, dos Estados e dos Municípios debaixo do controle direto, imediato e diuturno da vontade popular, jamais a de levar a cabo, bemsucedida, a cruzada da anticorrupção administrativa de que tanto precisa o País. Unicamente a democracia direta tem forças para operar tal milagre.

Entretanto, a complexidade da sociedade e das decisões a serem tomadas inviabiliza a participação direta em grande escala. Além disso, para que o modelo participativo se realize, ainda que parcialmente, alguns requisitos devem ser atendidos: "instituições representativas em todos os níveis sociais" com igualdade e efetividade asseguradas na participação; sentimento de pertencer a uma comunidade e consciência da responsabilidade de cada cidadão por planejar, executar e desfrutar das políticas públicas ${ }^{60}$, bem como por preservar a democracia participativa; e, por fim, a "diminuição da desigualdade sócio-econômica”, pois ela desestimula a participação política. Nota-se, todavia, que há um círculo vicioso, pois a realização de tais requisitos "só é possível com maior participação democrática” (FARIA, 1982, p. 123; p. 155 - 157).

De maneira semelhante, Macpherson (1978, p. 97 - 101) afirma que, ao menos no âmbito nacional, não é viável a democracia completamente direta. Isso porque nem mesmo os avanços tecnológicos possibilitam que a população delibere diretamente sobre tudo. Primeiramente, porque sempre será necessário que alguém formule as questões sobre as quais se decidirá. Em segundo lugar, mesmo que certo número de cidadãos pudesse formular tais questões, elas apresentariam um grau de complexidade muito elevado, de difícil compreensão para o conjunto da população. Além de que, muitas vezes, as respostas não podem ser reduzidas a sim ou não. Por fim, seria comum a apresentação de "exigências inconsistentes", como, simultaneamente, reduzir impostos e aumentar gastos governamentais. Diante disso, o autor conclui que a representação não pode ser

\footnotetext{
${ }^{60}$ Nesse sentido, Comparato (2006, p. 636) afirma que "todos têm o direito e o dever de participar das decisões que dizem respeito ao bem comum".
} 
dispensada. Portanto, “devemos confiar, embora não devamos confiar exclusivamente, na democracia indireta. O problema é tornar responsáveis os políticos”.

A realização de um modelo participativo de democracia pressupõe a mudança de consciência do povo, que deve deixar de "ver e agir como essencialmente consumidor" e passar a se ver e agir como responsável pelo seu desenvolvimento e pelo desenvolvimento da sociedade, além de uma diminuição radical da desigualdade socioeconômica. Porém, como esses requisitos só podem ser atingidos mediante uma participação democrática muito maior do que a atual, forma-se um círculo vicioso. Por outro lado, a consciência sobre os custos do crescimento econômico desordenado para o meio ambiente e para a qualidade de vida, bem como dos prejuízos causados pela apatia política para a concentração de poder econômico e político, mostra-se como uma possível saída para essa situação (MACPHERSON, 1978, p. 102 - 105).

Não obstante a existência de todas essas dificuldades, Comparato (2006, p. 660) salienta que

se toda a ação política, como vimos, deve ter por finalidade o bem comum do povo, seria um grosseiro absurdo que o próprio povo fosse em permanência excluído de julgar a justiça ou injustiça das políticas postas em prática, bem como de fazer atuar a responsabilidade dos governantes que as realizaram, sobretudo quando estes devem sua posição de mando à eleição popular ${ }^{61}$.

E acrescenta:

os grandes adversários da soberania do povo são, sempre e em qualquer circunstância, os membros das chamadas elites dominantes, justamente os grandes responsáveis pelo estado de penúria, ausência de instrução, ou mesmo aberrante miserabilidade, em que se encontra uma grande parcela, senão a maioria do povo.

Portanto, sem a atribuição efetiva de soberania ao povo não há verdadeira democracia, mas uma democracia meramente eleitoral. ${ }^{62}$ No Estado Democrático de Direito, ninguém pode ser excluído do exercício do poder político. E essa participação deve ser efetiva, isto é, deve produzir efeitos reais sobre as decisões políticas; não pode ser

\footnotetext{
${ }^{61}$ No mesmo sentido, Lafer, em seu prefácio à obra de Bobbio (1998, p. 23 - 24), assinala que, para esse autor, a institucionalização do controle dos governados sobre os governantes é "um dos poucos remédios válidos contra o abuso do poder" e "os melhores intérpretes do interesse coletivo são os próprios interessados".

${ }^{62}$ A propósito, Barros (2007b, p. 1 - 3) afirma que neste caso haveria uma politicatura, a qual é a ditadura da classe política, e não existiria Estado Democrático de Direito, mas somente um Estado Eleitoral.
} 
meramente formal e superficial, ou servir apenas para legitimar as decisões tomadas por aqueles que detêm o poder de fato.

Mas como o povo exercerá a soberania política em sociedades altamente complexas, que exigem ações especializadas e nas quais o governo direto é inviável?

Exercerá por meio da concepção e organização da soberania política como poder de controle do povo sobre a ação dos governantes (COMPARATO, 2006, p. 653).

O sentido empregado para a expressão "poder de controle" é extraído do Direito Empresarial, pois foi neste ramo do conhecimento jurídico que apareceu a moderna noção de poder de controle. Percebeu-se que, em grandes empresas, os acionistas podem perder o seu controle efetivo, transformando-se em meros investidores, pois este controle passa a ser exercido pelos administradores ou até mesmo por alguém de fora da organização (COMPARATO, 2006, p. 650 - 651).

Uma sociedade anônima pode ser controlada por um agente externo, ${ }^{63}$ por exemplo, quando depende dele para fornecimento de matéria prima ou escoamento da produção, bem como na hipótese de contrair grande dívida com uma instituição financeira, a qual pode passar a tomar decisões referentes à reorganização da companhia (COMPARATO, 2005, p. 39 - 45). Na sociedade política, este fenômeno é observado quando as grandes potências mundiais (ou mesmo grandes conglomerados empresariais) exercem sua "dominação financeira, comercial ou tecnológica" sobre os países periféricos, bem como no controle exercido pelas classes dominantes sobre os políticos ou sobre os órgãos do Estado (COMPARATO, 2006, p. 653).

Já no caso do controle exercido pelos administradores da empresa e não pelos acionistas, pode-se fazer um paralelo ${ }^{64}$ com os burocratas na sociedade política, os quais, por deterem todo o conhecimento técnico e toda a informação, muitas vezes acabam efetivamente dirigindo o Governo (COMPARATO, 2006, p. 651).

${ }^{63}$ Comparato (2005, p. 48) distingue o controle interno do externo na sociedade anônima da seguinte maneira: No primeiro caso, o titular do controle atua no interior da sociedade ( $a b$ intus), lançando mão de mecanismos de poder próprios da estrutura societária, notadamente a deliberação em assembléia. No segundo, o controle pertence a uma ou mais pessoas, físicas ou jurídicas, que não compõe quaisquer órgãos da sociedade, mas que agem de fora ( $a b$ extra).

${ }^{64}$ Pode-se também estabelecer uma relação entre o não comparecimento dos acionistas minoritários nas Assembléias Gerais das grandes companhias e a não participação dos eleitores nas eleições democráticas, bem como seu não acompanhamento do trabalho dos eleitos. Por outro lado, existe uma diferença importante entre tais realidades: o caráter impessoal e anônimo do poder de decidir nas sociedades anônimas, devido às complexas redes de participação acionária, contrapõe-se ao caráter personalista das disputas políticas entre as lideranças dos partidos e à concentração pessoal de poder na pessoa do chefe de governo ou Estado (COMPARATO, 2005, p. X - XI). Existe ainda em comum o fato de que, tanto na sociedade anônima como na sociedade política, não basta que o controle seja exercido conforme a legalidade, é necessário também que o seja de forma legítima (COMPARATO, 2005, p. 555). 
Tais situações ocorridas no mundo empresarial levaram ao desenvolvimento da idéia de poder como controle. Na sua origem francesa, o termo significa examinar, verificar, fiscalizar. Já na concepção oriunda do idioma inglês está presente a "noção de poder de mando ou dominação", a qual implica a supervisão e a imposição de diretrizes. O uso da expressão "controle" nas empresas é no sentido forte de origem inglesa ${ }^{65}$ (COMPARATO, 2006, p. 651).

O controle não se confunde com a dominação direta, como aquela exercida pelo senhor sobre seus servos, mas consiste na "prerrogativa possuída pelo titular de um poder superior de impor suas decisões sobre o titular de um poder inferior" (COMPARATO, 2005 , p. X).

Assim sendo, observa-se que

o controle é o poder jurídico moderno, próprio das sociedades ou organizações complexas, nas quais se manifesta necessariamente uma hierarquização de funções. Ele é, também, o poder de fato, exercido, $a b$ extra sobre os administradores de uma pessoa jurídica privada ou sobre os que detêm oficialmente o poder político. (COMPARATO, 2005, p. X).

Na grande empresa, "o controlador decide, em última análise, estabelecendo as grandes diretrizes da ação administrativa e supervisionando a atuação dos administradores ou agentes executivos" (COMPARATO, 2006, p. 654).

Na sociedade política, o controle soberano do povo também se exerce pelo estabelecimento de grandes diretrizes e pela supervisão dos representantes eleitos, valendose dos seguintes meios: aprovação da Constituição e de suas modificações, pois é ela que determina a organização do poder na sociedade; fixação das diretrizes gerais do governo, com metas de médio e longo prazo a serem observadas pelos diferentes governantes; eleição periódica dos titulares das funções governamentais; destituição dos governantes eleitos (tanto membros do Poder Executivo como do Legislativo), independentemente do cometimento de delitos, a qualquer tempo, quando entender que não estão atendendo às suas expectativas, cumprindo a Constituição e as diretrizes gerais que fixou (COMPARATO, 2006, p. 654 - 655).

Outros institutos pelos quais se exerce a soberania popular são: referendo (de leis, emendas constitucionais e de acordos ou tratados internacionais), alguns devem ser obrigatórios (como o caso das emendas constitucionais) e outros facultativos, podendo o próprio povo convocá-los; poder de iniciativa popular de projetos de lei ou emendas à Constituição; plebiscito, cujo poder de convocação nunca pode ser atribuído ao chefe de

${ }^{65}$ Maior desenvolvimento sobre os sentidos da palavra controle pode ser encontrado em COMPARATO e SALOMÃO FILHO, 2005, p. 27 - 30. 
Estado ou de governo (a fim de se evitar desvios que marcaram tragicamente a história e levaram a práticas autoritárias como de Napoleão III e Hitler), mas somente ao povo ou a uma minoria parlamentar qualificada; aprovação de planos de desenvolvimento e diretrizes gerais a serem observadas na elaboração das leis orçamentárias; e o poder de agir em juízo em defesa dos bens públicos (COMPARATO, 2006, p. 665 - 670).

A especialização e o controle recíprocos dos órgãos do Estado são imprescindíveis para coibir o abuso do poder e a ineficiência e, portanto, para a democracia. A repartição horizontal de poderes é uma das instituições com esse objetivo. Consagrada no princípio da Separação de Poderes, tem como regras básicas a nãocumulatividade do poder de propor com o poder de decidir e a atribuição a órgãos distintos do poder de estatuir e do poder de vetar. A outra é a repartição vertical de competências, o denominado Federalismo (COMPARATO, 2006, p. 670 - 680).

Para completar a caracterização da concepção de controle democrático do poder utilizada nesta dissertação, pondera-se que o exercício do poder soberano, mesmo que democraticamente, encontra limites éticos. O primeiro e o mais fundamental é o "sistema geral de direitos humanos, consubstanciado em vários documentos e pactos internacionais, e reproduzido e ampliado nas Constituições e leis fundamentais de múltiplos Estados" ${ }^{\text {"6 }}$. O segundo é o dever de respeito pelo próprio titular da soberania política ao direito positivo, especialmente aos procedimentos por ele estabelecidos para sua modificação (COMPARATO, 2006, p. 665).

Diante dessas considerações, Comparato (2006, p. 665) define o regime democrático como

aquele em que a soberania pertence ao povo, no interior de um Estado, ou ao conjunto dos povos, no plano mundial, para a realização do bem comum de todos (regime republicano), submetendo-se sempre o exercício desse poder soberano às normas jurídicas que consubstanciam os grandes princípios éticos (verdade, justiça, amor, liberdade, igualdade, segurança e solidariedade).

Entretanto, o referido autor(2005, p. 38) ressalva que

a definição legal dos centros de poder, no direito atual, parece coincidir, raramente, com a realidade do poder. A declaração constitucional de que 'todo o poder emana do povo e em seu nome é exercido', por exemplo, tem se apresentado mais como enunciado de princípio, de valor programático, do que

\footnotetext{
${ }^{66}$ Os direitos fundamentais limitam inclusive a vontade da maioria democraticamente formulada que não pode contrariá-los (FERRAJOLI, 2006, p. 792).
} 
como disposição efetivamente vinculante na prática política, onde a noção de 'povo' se revela excessivamente abstrata.

É preciso reconhecer, todavia, que, como assinala a teoria da análise econômica da democracia, os homens agem de maneira racional, buscando fins egoístas mediante a definição dos objetivos e a escolha dos melhores meios de atingi-los. Tal comportamento, também se aplica à política, ou seja, os políticos buscam o poder não para executar políticas em que acreditam, mas para atingir fins particulares, ou seja, para obter "renda, prestígio e poder". Como para tanto precisam ser eleitos, os políticos avaliam as preferências dos cidadãos com o objetivo principal de "maximizar o apoio político" para serem eleitos ou reeleitos, e não de proporcionar o bem-estar da coletividade. Da mesma maneira, o cidadão age racionalmente ao votar: compara os benefícios recebidos do partido que está no poder com os que esperaria receber se outro estivesse governando e vota no partido (ou candidato) que proporcionará mais benefícios para si, e não para a coletividade $^{67}$ (DOWNS, 1999, p. $26-60$ ).

Diante dessa realidade, as instituições políticas devem cumprir o papel de fazer com que a perseguição de fins individuais e egoísticos leve à realização de objetivos coletivos. Porém, não se pode esperar que reformas institucionais sejam suficientes para resolver problemas como esses.

Controlar, democraticamente, o poder político não significa, portanto, a simples contenção do poder a fim de evitar abusos, característica do Estado Liberal que serviu aos interesses de manutenção do sistema capitalista, sem nenhuma preocupação com a democracia material, mas também não se refere à crença utópica de um governo direto em uma sociedade com o grau de complexidade da contemporânea. Trata-se do controle dos atos dos governantes dentro de um sistema representativo, porém no sentido forte de direcionamento do poder, de estabelecimento de metas e diretrizes mediante planos, orçamentos e políticas públicas, bem como da responsabilização daqueles a quem compete sua execução, com o objetivo perseguido pelo Estado Democrático de Direito de implantar plenamente os direitos humanos e fazer justiça material.

É sob essa perspectiva que se investigará em que medida o Parlamento é capaz de exercer eficazmente o controle do poder político.

${ }^{67}$ Esse modelo como pressupõe que todos os cidadãos tenham acesso gratuitamente às informações necessárias para sua tomada de decisão (DOWNS, 1999, p. 70). Entretanto, sabe-se que isso não ocorre, o que distorce o sistema. 
Dito isto, resta, para concluir a delimitação do problema desta pesquisa, uma breve discussão sobre o controle democrático do poder político frente ao poder econômico.

\subsubsection{O Controle Democrático do Poder Político frente à Economia.}

Como o Estado Democrático de Direito tem como fim a realização da justiça material e a plena concretização dos direitos humanos mediante uma transformação estrutural da sociedade, o controle democrático do poder político deve abranger as decisões da esfera econômica ${ }^{68}$.

Isso não era aceito no modelo do Estado Liberal, visto que os fundadores da Ciência Econômica, no início do século XVIII, defendiam a não interferência da política no âmbito da economia, pois esta seria regida por "leis naturais", cabendo ao Estado, exclusivamente, a garantia da ordem pública (COMPARATO, 2006, p. 583). De maneira semelhante, os teóricos neoliberais da segunda metade do século XX defenderam o estabelecimento de limites para a democracia a fim de garantir que a esfera econômica ficasse livre de controle político (PIERSON, 1993, p. 180 - 181).

A liberdade da esfera econômica frente ao controle político interessa somente à classe dominante e esvazia o conteúdo da democracia, protegendo os interesses dos proprietários de capital privado e excluindo a maioria dos processos decisórios e da apropriação das riquezas ${ }^{69}$. Primeiramente, porque o poder econômico concentrado e livre de controles direciona a ação do Estado em função de seus interesses, por meio de sua influência sobre os governantes eleitos, o que por si só já afronta a lógica da democracia, segundo a qual o Estado deve se submeter à soberania popular ${ }^{70}$. Em segundo lugar, o

${ }^{68}$ Dahl (1990, p. 73) afirma que, inclusive, a melhor ordem econômica contribuiria para a realização dos ideais democráticos, mediante "uma distribuição de recursos políticos favorável às metas de igualdade no voto, participação efetiva, entendimento esclarecido e controle final da agenda política por todos os adultos sujeitos às leis".

${ }^{69}$ Santos (2000, p. 122) assevera que "a separação entre o político e o económico permitiu, por um lado, a naturalização da exploração económica capitalista, e, por outro, a neutralização do potencial revolucionário da política liberal, dois processos que convergiram para a consolidação do modelo capitalista das relações sociais".

${ }^{70}$ Grau $(2008$, p. 59 - 65; 125 - 128; 136) afirma que o direito é um “instrumento de mudança social”, pois, embora seja um produto da estrutura econômica, nela interfere produzindo alterações, ou seja, há um direito pressuposto que condiciona a elaboração do direito posto, mas é modificado por este. Assim sendo, "o modo de produção capitalista, modo de produção essencialmente jurídico, reclama por um direito posto, construído sobre o seu direito pressuposto". Tal direito atua na constituição e na preservação do modo de produção capitalista, por meio das regras que garantem o funcionamento do mercado, o complementam, substituem diante de situações de riscos e compensam suas disfunções, a fim de evitar, por exemplo, reações da classe operária diante das mazelas por ela enfrentadas. Portanto, o Estado atua tanto na organização dos "processos que fluem segundo as regras de economia de mercado", como os influencia a fim de alcançar determinados objetivos sociais. Entretanto, mesmo quando intervém na economia, o Estado se revela "essencialmente 
mercado livre do controle político democrático é um fator multiplicador de injustiças, o que contraria o objetivo do Estado Democrático de Direito de fazer justiça material. Em terceiro lugar, a concretização dos direitos humanos (fim primordial do Estado), especialmente os econômicos e sociais, depende da maneira como são alocados os recursos materiais; assim sendo, de que vale a democracia no Estado se o controle democrático do poder político não abranger a esfera econômica ${ }^{71}$

Inclusive, segundo Bobbio, no prefácio de Lafer à sua obra (BOBBIO, 1998, p. 23), “o problema do desenvolvimento da democracia no mundo contemporâneo não é apenas quem vota, mas onde se vota e se delibera coletivamente, pois é no controle democrático do poder econômico que, segundo ele, se vencerá ou se perderá a batalha pela democracia socialista".

Entretanto, as alternativas ${ }^{72}$ socialista e social-democrata falharam, não só pela ineficiência, como também pela incapacidade de criar um modelo satisfatório de controle democrático da economia, já que promoveram a concentração do poder nas mãos dos burocratas e não do povo. Além disso, com a intensificação da globalização da

capitalista". Desta maneira, o capitalismo não requer o afastamento do Estado dos mercados, mas sua atuação reguladora a fim de assegurar sua preservação.

${ }^{71}$ Nesse sentido, ver as análises feitas por Pierson (1993, p. 181 - 182; p. 188) sobre as críticas dos socialistas e sociais democratas, e de Faria (1982, p. 147) sobre a crítica de Macpherson aos modelos de democracia liberal.

72 Menciona-se também o modelo do socialismo de mercado, o qual procurou combinar princípios de propriedade coletiva com a continuidade da alocação de recursos por meio do mercado. Propõe-se a eliminação das grandes corporações privadas, substituindo-as por cooperativas de trabalhadores dirigidas a partir de uma democracia interna. Entretanto, trata-se de uma forma limitada de democratização, pois há democracia dentro da empresa, mas não entre as empresas, onde permanece a competição de mercado. Além disso, ele promete melhorias para os que já estão empregados, mas não apresenta caminhos para incluir aqueles que estão desempregados. Por fim, há a promessa de controle democrático sobre decisões econômicas em uma pequena esfera, mas não sobre a economia como um todo, pois os governos continuam sendo representativos e muitas decisões nas grandes empresas dirigidas por trabalhadores continuam restritas a administradores profissionais (PIERSON, 1993, p. 185 - 189). Proposta semelhante é defendida por Dahl (1990, p. 74 - 88), o qual propõe uma ordem econômica que apresenta como metas: justiça na distribuição e eficiência na utilização dos escassos; estimular a responsabilidade e a honestidade pessoal; bem como permitir a expansão da liberdade para adquirir os recursos econômicos necessários para uma vida boa. Tais metas seriam incompatíveis com o socialismo burocrático, pois objetivam a dispersão do poder, e não sua concentração, o que não dispensa o controle centralizado de alguns aspectos importantes da economia. Numerosas decisões importantes deveriam ser descentralizadas entre empresas relativamente autônomas, que funcionariam dentro de limites estabelecidos por um sistema de mercados e normas democraticamente instituídas para orientar o caminho até os objetivos estabelecidos. Para operacionalizar tal ordem econômica, o autor propõe "um sistema de empresas econômicas coletivamente possuídas e democraticamente geridas por todas as pessoas que para elas trabalham", assegurando-se a todos os empregados a igualdade do direito de voto. $\mathrm{O}$ autor saliente que as empresas autogeridas apresentam vantagens tanto em relação às sociedades anônimas como em relação às empresas estatais. Nesse sistema, poderia haver diferenças salariais entre os empregados das empresas autogeridas, porém, tal diferença deve ser pequena e seu superávit deveria ser dividido igualmente entre todos. Alguns mecanismos corretivos da desigualdade entre as empresas poderiam ser adotados, como os de política fiscal. Por fim, o autor salienta que a igualdade da cidadania nas empresas "reduziria em muito as relações conflitivas dentro das firmas e, indiretamente, na sociedade e na política em geral". 
interdependência das economias nacionais, reduziu-se drasticamente a capacidade de intervenção do Estado por meio dos instrumentos de política econômica (PIERSON, 1993, p. $182-185)$.

As falhas dos modelos alternativos ao modelo liberal não afastam a necessidade de controle democrático sobre a economia, ainda mais diante das consequências para o meio ambiente, da situação de miséria em que vive grande parcela da humanidade e da radical desigualdade na distribuição das riquezas decorrentes dos atuais níveis de concentração e descontrole ${ }^{73}$ do poder econômico ${ }^{74}$.

Além disso, o mercado não se organiza em função das preferências do consumidor, mas sim dos detentores do poder econômico, ${ }^{75}$ revelando-se cada vez mais incapaz de promover sua auto-regulação, com sucessivas crises econômico-financeiras, o que reforça a necessidade de controle democrático sobre a economia ${ }^{76}$.

Diante disso, como assinala Gianotti (2009, p. 6), “o desafio não é encontrar novos mecanismos de mercado, mais sadios e consistentes, mas instituir órgãos reguladores do funcionamento dos vários mercados capazes de legitimar seu funcionamento, isto é, assegurar que funcionem em vista do bem-estar e do bem-ser da população".

\footnotetext{
${ }^{73}$ Rossi (2008, A2) aponta que "os mercados financeiros ganharam tal autonomia que, apesar de o Estado ter crescido muito ele tornou-se impotente, reduzindo-se a ação dos políticos a somente contar histórias". A propósito, Bello e Silva (2007, p. 9) salienta que "a subordinação da política ao mercado e a era da indeterminação expressam o predomínio da pequena política (mera disputa pelo poder sem haver confronto entre projetos hegemônicos distintos) e o simultâneo enfraquecimento da sociedade civil (enquanto campo de disputa por hegemonia) e da sociedade política (poder do aparato coercitivo do Estado, nesse caso frente aos capitais)".

${ }^{74}$ A seguinte análise de Comparato (2005, p. 553) é fundamental para a compreensão do fenômeno do poder econômico: "na concepção tradicional, o mercado é tecnicamente organizado em função do consumidor, cujas decisões fundamentam, em última análise, a correspondência entre ofertas e demandas, num regime de produção essencialmente concorrencial. A situação de monopólio é considerada excepcional e combatida como autêntica aberração. Hoje, reconhece-se que o mercado de bens, de serviços e de força-trabalho é formado pelas decisões do conjunto de empresas dotadas de poder econômico, ao qual se submetem todas as demais unidades, pequenas ou médias. As relações que se estabelecem entre esses setores, o nuclear e o periférico, são em tudo análogas ao relacionamento entre países desenvolvidos e subdesenvolvidos. O poder econômico, portanto, é a regra e não exceção. Ora, a finalidade última desse poder, do qual todos nós dependemos, não pode ser apenas nem prioritariamente, a produção e a partilha de lucros entre proprietários ou capitalistas; não deve ser, tampouco, assegurar ao empresário um nível de elevada retribuição econômica e social. O poder econômico é uma função social, a serviço da coletividade".

${ }^{75}$ Analogamente, ocorre essa situação com relação ao poder político: é ingenuidade acreditar, comparando-se os cidadãos com os consumidores, que são suas decisões e preferências que determinam os rumos do Estado. Diante do poder da mídia, da ideologia dominante, e de todos os recursos empregados nas milionárias campanhas eleitorais, bem como nas campanhas publicitárias oficiais, evidencia-se que as preferências dos eleitores são, em geral, dirigidas por aqueles que detêm o poder econômico e o poder político de fato; até mesmo as opiniões sobre prioridades administrativas e os rumos do país muitas vezes acabam sendo construídas artificialmente. Assim sendo, nem mesmo nos momentos eleitorais o povo é verdadeiramente livre quando não há democracia plena.

${ }^{76}$ Cf. COMPARATO, 2005, p 559 e FARIA, 1982, p. 146.
} 
Porém, trata-se de um impasse difícil de ser resolvido, tanto por sua complexidade como pelo fato apontado por Comparato (2006, p. 653) de que

o capitalismo é radicalmente contra toda e qualquer experiência de democracia autêntica, dentro ou fora da empresa, uma vez que ela implica atribuição do poder de controle, por igual, ao conjunto dos integrantes da empresa - capitalistas e trabalhadores -, ao conjunto dos consumidores no mercado, ou ao corpo de cidadãos que formam o povo soberano.

Como a atuação transformadora do Estado no domínio econômico implica um confronto com o regime capitalista de produção, não será fácil realizá-la plenamente enquanto os interesses políticos dominantes permanecerem "identificados com o status quo", ou seja, enquanto o poder político continuar preso aos grupos mais poderosos da classe dominante que querem conservar a situação vigente. Deve-se reconhecer, portanto, que não há neutralidade na atuação do Estado na esfera econômica, pois as alternativas disponíveis são, mutuamente, excludentes, o que gera conflitos entre classes e grupos sociais antagônicos (IANNI, 1989, p. 170; 178 - 179).

Apesar de todas essas dificuldades, conserva-se a crença no controle democrático sobre a economia ${ }^{77}$, pois o poder político apresenta como características distintivas: não se subordinar juridicamente a nenhuma outra forma de poder e ser exercido na "esfera global da sociedade política, que é a mais abrangente de todas", de maneira que se sobrepõe a todas as outras formas de poder (COMPARATO, 2006, p. 592).

Assim sendo, é necessário, segundo Comparato (2006, p. 583), intensificar "um movimento de progressiva defesa dos direitos humanos, e de combate ao abuso de poder, não só político, mas também econômico e religioso" que teve início ainda no final do século XVII.

Faz-se necessário, como assinalam Martin e Schumann (1997, p. 325), a "restauração do primado da política sobre a economia".

Salomão Filho (In: COMPARATO, 2005, p. 11 - 12; p. 14 - 18; p. 22) também defende o combate ao poder econômico, porque ele é incompatível com a justiça social e responsável pela concentração de renda. Para tanto, propõe: a diluição acionária, a qual, segundo ele, é vantajosa tanto para a empresa como para o mercado de capitais; a intervenção nas estruturas que concentram poder, especialmente devido ao seu potencial criador e distribuidor de conhecimento, a partir do que é capaz, inclusive, de criar gostos nos consumidores e estruturar a sociedade "em torno de dois grupos bastante distintos: os

\footnotetext{
${ }^{77}$ Um exemplo de combate ao abuso do poder econômico é a criação de normas que prevejam a sanção de perda do direito ao controle da companhia do seu titular que, independentemente de demonstração de desonestidade, não dirigir a empresa tendo em vista sua função social (COMPARATO, 2005, p. 561).
} 
consumistas e os excluídos"; ${ }^{78}$ e a criação de "determinantes estruturais" que estimulem os indivíduos a um comportamento cooperativo, e não estratégico, visando apenas ao próprio benefício.

\subsection{Instituição Jurídica Analisada: Parlamento.}

O Parlamento ${ }^{79}$ tem sua origem na Inglaterra $^{80}$ do século XIII, quando representantes das diferentes regiões passaram a ser convocados para colaborar com o rei. A partir do reinado de João Sem Terra, ganhou mais poder, pois parte de seus membros passou a ser eleita por seguimentos da população e só podiam ser criados tributos com sua aprovação $^{81}$. Sobreveio o absolutismo monárquico e o Parlamento perdeu a capacidade de impor suas decisões ao Monarca. Nos séculos XVII e XVIII, as Revoluções Liberais Burguesas atribuíram ao Parlamento o monopólio da produção normativa e condicionaram o direito de votar e ser votado para a representação parlamentar a determinados patamares de renda e propriedade ${ }^{82}$. Em fins do século XIX e início do século XX, a universalização

78 A propósito, Salomão Filho (In: COMPARATO, 2005, p. 21) pondera que o poder econômico concentrador de conhecimento e de informações, não só desequilibra as relações instantaneamente como ainda permite a perpetuação da relação de desequilíbrio, já que impede que a parte sem poder adquira informação ou conhecimento. Conseqüência direta é então o desequilíbrio das relações do ponto de vista econômico e então o desequilíbrio de distribuição de renda. A relação entre poder econômico concentrado e subdesenvolvimento é, nessa perspectiva, de implicação necessária.

79 Segundo Ferreira (1995, p. 359), Congresso e Parlamento são expressões equivalentes, “a primeira preferida pelas democracias americanas e a segunda pelos países da Europa”.

${ }^{80}$ Tanto na Inglaterra como nos Estados Unidos da América o Parlamento se estruturou de forma bicameral. No primeiro caso, o objetivo era o estabelecimento de uma Câmara representativa do povo e outra da elite, composta pela nobreza. No segundo, essa estrutura se deveu à forma federativa do Estado americano, procurando-se conciliar a unidade nacional com a autonomia das unidades federativas, mediante a criação de uma Câmara Baixa, composta segundo critérios populacionais, e de uma Câmara Alta, com representação igual entre os Estados, a qual também cumpriria a função de conter eventuais excessos de uma Assembléia com bases populares. Em muitos lugares, sobretudo onde foi adotado o sistema parlamentarista, o bicameralismo foi substituído pelo formato de câmara única. Mesmo onde foi conservada a existência de duas câmaras, a composição e a função das Câmaras Altas passaram por muitas modificações, ou o bicameralismo perdeu boa parte de seu sentido, pois as duas Casas tendem a apresentar uma convergência de fins, servindo quase que exclusivamente para uma revisar as decisões da outra. - Cf. LOEWENSTEIN, 1986, p. 247 - 248, BONAVIDES, 2004, p. 286 - 288, PALUDO, 1999, p. 26 - 33, GRIFFITH, RYLE, WHEELER-BOOTH, 1989, p. 3, BASTOS, 1995, p. 4 - 5 e Kelsen, (2009b, p. 45.

Hume $(1963$, p. 68 - 69) relata que na Inglaterra, "a parte de poder concedida a Casa dos Comuns é tão grande que ela comanda em absoluto todas as outras partes do governo", de maneira que a concordância do rei com a vontade do Parlamento se revela uma "mera formalidade". O autor salienta, ainda, que o Poder Executivo está sujeito ao Legislativo em qualquer governo, além de que seu exercício depende de grande despesa, mas coube à Casa dos Comuns o "direito exclusivo de conceder fundos". Por fim, aponta que a Casa dos Comuns não amplia o próprio poder porque o interesse do corpo legislativo é limitado pelo dos indivíduos, aos quais não interessa tal dilatação.

${ }^{81}$ A consolidação do Poder Legislativo esteve ligada, em alguns momentos, sobretudo nas suas origens, ao controle sobre a tributação (SALDANHA, 1981, p. 25 - 26).

82 Até 1829, os católicos não poderiam participar do Parlamento; em 1884 o sufrágio foi ampliado consideravelmente a todos os chefes de família; e somente em 1929, foi estendido às mulheres maiores de 20 anos (Paludo, 1999, p. $21-23$ ). 
do sufrágio mudou seu perfil, pois deixou de ser o lugar do consenso, da identidade ideológica e passou a ser o das fissuras, do dissenso, dos partidos, das diferentes ideologias e concepções a respeito do direito e do papel do Estado ${ }^{83}$. Ainda nas décadas de 1920 e 1930, as vias ideológicas extremistas pregaram a falência dos Parlamentos. Entretanto, procuraram, sem sucesso, uma instituição que pudesse substituir o sistema representativo liberal, como os modelos corporativista e soviético, os quais logo mostraram servir a interesses autoritários. Após a crise de transição do Estado Liberal para o Social, o Parlamento recuperou seu prestígio nos países de governo democrático, embora tenha sofrido mudanças profundas. ${ }^{84}$

Kelsen (2000b, p. 48) destaca que o Parlamento moderno nasceu, diferenciando-se de outras instituições semelhantes dos Estados antigos, com sua “declaração de independência" em relação ao povo, pois, naqueles Estados, os eleitos estavam vinculados aos seus eleitores por mandatos imperativos e eram responsáveis perante eles.

As mudanças ocorridas, tanto na sociedade como no Parlamento, não fizeram com que esta instituição perdesse sua característica de "órgão representativo, por excelência, da soberania popular” (BASTOS, 1995, p. 5). É inegável, todavia, que o Parlamento perdeu sua centralidade política para outros espaços decisórios, especialmente em matéria econômica, limitando-se, em muitos regimes democráticos, a "registrar decisões que foram tomadas alhures" (COTTA, 1995, p. 886 - 887). Ou, como assinala Morais (2004, p. 141), "por vezes, recuado para a posição fáctica de estruturas carimbantes dos impulsos do Executivo, para o estatuto de órgãos de mera fiscalização política dos governos, ou mesmo para anfiteatros de pura dramatização mediática da conflitualidade política". Entretanto, como na atualidade a democracia não pode prescindir do sistema representativo, ela "só viverá se o parlamentarismo se revelar um instrumento capaz de resolver as questões sociais de nosso tempo" (KELSEN, 2009b, p. 45 - 46).

\footnotetext{
83 Ferreira Filho (1968, p. 70 - 71) assinala que o sufrágio universal provocou a ruína do sistema representativo do tipo construído pela Revolução Francesa e fez surgir um "foco de tensão entre o poder econômico e o poder político" (os operários representavam a maioria dos eleitores), de maneira que o Parlamento se tornou um palco de luta entre diferentes interesses ("a mentalidade de luta de classes transporta-se para as pugnas parlamentares", ou seja, "os representantes dividem-se como reflexo de uma sociedade dividida").

${ }^{84}$ Cf. MELO, 1991, p. 138 - 146, CLÈVE, 1993, p. 43 - 49 e BONAVIDES, 2004, p. 284 - 285. Em termos doutrinários, as obras de Locke (1632 - 1704) e Montesquieu, destacando-se, do primeiro o "Ensaio sobre o Governo Civil" (1690) e, do segundo, o "Espírito das Leis" (1748) podem ser apontadas como os primeiros fundamentos do Parlamento. Após a Revolução Francesa, a doutrina sobre o Parlamento teve como primeiro expoente Mill, político inglês com grande influência sobre o pensamento ocidental do século XIX (PALUDO, 1999, p. 21 - 23; 34).
} 
Assim, como assinala Cotta (1995, p. 888), “o futuro das instituições parlamentares depende, portanto, em grande parte, da sua capacidade de adaptação, no que respeita a estruturas e modos de operar, ao papel de elemento de equilíbrio num sistema político aberto e pluralista".

Observa-se, a partir dessa breve exposição histórica, que, em suas origens, o Parlamento existia para defender os interesses dos nobres perante o rei e, após as Revoluções liberais, formular a vontade Estatal segundo os interesses da burguesia. Somente com a universalização do sufrágio a instituição ganhou uma configuração mais popular. Entretanto, como assinalado acima, está perdendo sua centralidade política e não se mostra capaz de desempenhar, satisfatoriamente, suas funções, o que requer adaptações na sua estrutura, no seu modo de operar, e até mesmo no seu papel institucional.

Dito isso, passa-se a apresentar ${ }^{85}$ as funções e a estrutura do Parlamento.

\subsubsection{Funções do Parlamento.}

Diversas funções são atribuídas ao Parlamento por diferentes doutrinadores do Direito do Estado ${ }^{86}$.

Canotilho (1993, p. 740 - 745) as classifica em seis categorias: eletiva e de criação (“eleição de determinados órgãos constitucionais ou de alguns membros destes"); legislativa (feitura de leis, ressaltando-se que, embora não detenha o monopólio da competência legislativa, ainda detém uma reserva de matérias sobre as quais somente ele pode legislar); controle (perguntas e interpelações para apurar determinados fatos, comissões de inquérito, recebimento de petições com reclamações de cidadãos, votação de moção de censura que pode levar à queda do governo); fiscalização (controle do cumprimento da Constituição e das finanças); autorizante (por exemplo, autorização para o

\footnotetext{
${ }^{85}$ Trata-se de simples apresentação, pois a discussão sobre os problemas enfrentados pelo Parlamento no exercício de sua função e como sua estrutura influencia isto será realizada no próximo capítulo.

${ }^{86}$ Por exemplo, Caggiano (2003, p. 149) apresenta as seguintes: representação dos destinatários do poder político, legislação, controle, investigação, eleitoral, jurisdicional, deliberativa, administrativa, de orientação política e de comunicação. Moraes (2005, p. 372) afirma que cada Poder possui uma função predominante (típica), porém não exclusiva, de maneira que também exerce funções atípicas. Segundo este autor, as funções típicas do Poder Legislativo são legislar e fiscalizar, enquanto as atípicas são julgar e administrar. Guimarães (2000, p. 11 - 14) aponta como principais funções dos Parlamentos: representação, legislação, controle do Executivo e legitimação. Segundo ela: a representação é a principal função e base das demais; legislação é a mais característica do Parlamento, ainda que boa parte dos poderes normativos esteja hoje concentrada no Poder Executivo; controle e a fiscalização são fundamentais para a consolidação democrática e para conter a expansão da burocracia para todas as esferas sociais e a da ação política, pois o Parlamento é quem deve exercer o papel de "lócus privilegiado para o confronto de interesses e como área de compromissos"; pela legitimação o "Poder Legislativo, ao se posicionar enquanto intermediário das manifestações de apoio e contestação da sociedade perante o Governo, interfere diretamente na outorga ou subtração da legitimidade política desse organismo político".
} 
Governo contrair ou ceder empréstimos); e representação (atos do Estado no âmbito internacional, como a aprovação de tratados).

Já Silva (2001, p. 522 - 523) apresenta cinco funções: legislativa (elaboração de leis segundo o processo legislativo estabelecido na Constituição); meramente deliberativas (atos concretos e autorizações mediante decretos legislativos e resoluções); fiscalização e controle (pedidos de informação, comissões parlamentares de inquérito, tomada de contas, controle externo com auxílio do Tribunal de Contas); julgamento de crimes de responsabilidade; e constituintes (elaboração de emendas à Constituição).

Provenza (2000, p. 50 - 53) afirma que Parlamento deve garantir a limitação do poder, cabendo-lhe, tipicamente, para tanto, "transferir legitimidade ao direito posto (edição da norma) e aferir permanentemente essa legitimidade nos atos de execução dos demais (fiscalização). Isso porque é o órgão vocacionado para tal (câmara de ressonância dos anseios da coletividade)".

Bastos (1995, p. 6) salienta que, embora tenha outras atribuições como as administrativas, investigatórias e de colaboração com o Executivo, "ao Legislativo cabe essencialmente, respondendo às aspirações do povo, realizar por meio de normas subconstitucionais as grandes metas e fins almejados pela Constituição, com os limites que esta mesma impõe ao Estado em benefício do cidadão".

Weber entende que o Parlamento tem a função de proteger as liberdades e é o lugar mais adequado para ocorrer o recrutamento, a seleção e a formação de líderes políticos, o que seria a única forma de controlar a administração burocrática, isso porque, como o poder da burocracia derivava de seus conhecimentos, o único meio de controlá-la seria ter acesso a eles também, o que pode ser feito mediante o trabalho nas comissões parlamentares (BEETHAN, 1979, p. 153 - 157; 184).

Griffith, Rile e Wheeler-Booth (1989, p. 6 - 8) afirmam que, ao menos na Inglaterra, o Parlamento não tem a função de governar. O que faz é servir como um fórum no qual representantes dos diferentes seguimentos da sociedade debatem publicamente os problemas sociais, conferir poderes ao Governo para implementar políticas que possam solucioná-los, bem como criticá-lo e censurá-lo quando não age de acordo com o que lhes parece ser o interesse público ou a melhor maneira de governar. Cabe-lhe, portanto, responsabilizar o Governo ${ }^{87}$. Além disso, autoriza os gastos públicos por meio da votação

\footnotetext{
${ }^{87}$ Nesse sentido, os autores (1989, p. 10) ressaltam que "the Government may govern, but Parliament is the forum for the public debate and criticism of those acts of government. Parliament is essentially a debating body".
} 
do orçamento e atua como garantidor das liberdades do povo, devendo, para tanto, assegurar a oportunidade de debate de todos os problemas sociais e de todas as visões sobre eles.

Cotta (1995, p. 886) reconhece o papel legislativo do Parlamento, sobretudo em algumas matérias que não comportam decisões no âmbito da negociação de interesses particulares ou setoriais, mas destaca suas funções de controle e "reguladora da competição política", pois o fato de abrigar diferentes tendências políticas, simultaneamente, permite mediar as disputas políticas, expressando as divergências continuamente dentro das vias institucionais.

Schwartz (1966, p. 73 - 74) aponta que, como o Congresso é o único órgão do Governo Federal norte-americano investido da competência legislativa, sua função primordial é legislar. Porém, “tão importante quanto legislar é fiscalizar atentamente a administração", e fornecer ao público as informações sobre as grandes questões de interesse nacional que nele são discutidas abertamente, pois é o "grande fórum em que se expressam as idéias dirigidas a cada cidadão". No desempenho deste último papel, sua atuação é mais importante como "modelador do que como receptáculo da opinião pública", pois o debate parlamentar permite a compreensão das questões sobre as quais delibera pelo público que pode se posicionar perante elas ${ }^{88}$.

Bonavides (2004, p. 285) resume as funções do Parlamento a legislar e controlar, ${ }^{89}$ ressaltando que aquela sofre restrições que parecem ser incontornáveis, mas esta apresenta amplas possibilidades de aperfeiçoamento e ampliação.

Bucci (2001, p. 243) afirma que ao Parlamento, juntamente com a direção política do governo, também compete a decisão sobre as políticas públicas.

Adotar-se-á o entendimento segundo o qual as funções do Parlamento são essencialmente duas: a legislativa e a de controle. Entende-se, em primeiro lugar, que sua atuação administrativa não constitui uma função, mas somente um meio para exercê-las. Da mesma maneira, representação e legitimação não são funções do Parlamento, mas,

\footnotetext{
${ }^{88}$ GRIFFITH, RYLE, WHEELER-BOOTH (1989, p. 522) concluem que "Parliament does at considerable lentth discuss a vast range of public and individual constituency matters and seeks constantly to reduce the area that Governments wish to keep secret. And to that extent, it holds Governmente to account, though imperfectly".

89 Nesse sentido, Loewentein (1986, p. 242) ressalta que o Parlamento exerce duas funções igualmente importantes: a legislativa e a de controle político. Para bem desempenhar essas funções, dispõe de três tipos de controle intra-órgão: a independência funcional, que consiste na sua capacidade de realizar suas atividades sem pressão exterior, seja de outros órgãos de poder ou das forças extra-constitucionais; a autonomia funcional, que consiste na proteção da minoria contra o domínio tirânico da maioria; sistema bicameral, o qual consiste na distribuição da função legislativa entre duas Casas Legislativas separadas.
} 
respectivamente, o fundamento e a consequência de seu exercício. Ou seja, o Parlamento legisla e controla o poder político porque representa o povo, e pelo exercício dessas funções, legitima, democraticamente, tal poder. Quanto à função legislativa, compreendese que ela abrange a elaboração de emendas à Constituição (pois também são normas produzidas pelo Parlamento, sendo apenas de espécie diferente). Por fim, entende-se que a função de controle abrange a orientação política do Estado (mediante a definição de objetivos e diretrizes, bem como a escolha de membros de outros órgãos), a formação de lideranças políticas e a responsabilização dos executores das políticas (o que inclui fiscalização, investigação e julgamento político de autoridades). Aliás, a própria função legislativa, de certa forma, pode ser compreendida como uma manifestação do controle do poder político exercido pelo Parlamento.

\subsubsection{Função Legislativa.}

A função legislativa é apontada como a mais típica do Parlamento, pois revela seu modo próprio de operar, ou seja, por meio de debates, votações e deliberações. Esse modo de operar deve permitir que as decisões políticas sejam tomadas a partir de amplas discussões e sob a influência de muitas e diversificadas informações oriundas das diversas correntes políticas que compõem o Parlamento (CAGGIANO, 2003, p. 151 - 152).

O exercício da função legislativa se dá de acordo com um conjunto de normas que definem o processo (ou procedimento) legislativo. Segundo Moraes (2005, p. 568), juridicamente, trata-se do "conjunto coordenado de disposições que disciplinam o procedimento a ser obedecido pelos órgãos competentes na produção de leis e atos normativos que derivam diretamente da própria constituição”. E, sociologicamente, consiste no "conjunto de fatores reais que impulsionam e direcionam os legisladores a exercitarem suas tarefas" $" 90$.

Pelos diferentes processos legislativos são produzidas as seguintes espécies normativas: emendas constitucionais ${ }^{91}$, leis complementares ${ }^{92}$, leis ordinárias ${ }^{93}$, medidas

\footnotetext{
${ }^{90}$ Canotilho (1993, p. 941) conceitua o procedimento legislativo como "um complexo de actos, qualitativa e funcionalmente heterogéneos e autónomos, praticados por sujeitos diversos e dirigidos à produção de uma lei do Parlamento". Silva (2001, p. 525 - 526) afirma que o processo legislativo consiste no "conjunto de atos realizados pelos órgãos legislativos visando à formação de leis constitucionais, complementares e ordinárias, resoluções e decretos legislativos". Os autores supracitados também apresentam diferentes fases para o processo legislativo. Cf. MORAES, 2005, p. 571 - 587, SILVA, 2001, p. 525 - 535, CANOTILHO, 1993, p. 942 - 947, BASTOS, 1995b, p. 75 - 76 e SCHWARTS (1966, p. 90 - 96).

${ }^{91}$ Emenda constitucional é uma espécie legislativa que: para ser aprovada, necessita do voto favorável de três quintos dos membros de cada uma das casas do Congresso, em dois turnos de votações separadas, sendo que, quando rejeitada ou prejudicada, não poderá ser reapresentada na mesma sessão legislativa; sua iniciativa é privativa de poucos legitimados; seu processo de aprovação encontra limitações materiais (normas
} 
provisórias ${ }^{94}$, leis delegadas ${ }^{95}$, decretos legislativos, resoluções ${ }^{96}$ e leis orçamentárias (são leis ordinárias, mas apresentam especificidades no seu procedimento de elaboração) ${ }^{97}$.

\subsubsection{Função de Controle.}

Os Estados democráticos constitucionais apresentam quatro formas de controle externo: o do Parlamento frente ao Governo; o do Governo frente ao Parlamento; o dos Tribunais frente ao Parlamento e ao Governo; e o do eleitorado frente aos demais detentores do poder, sendo que os Tribunais, em geral, estão excluídos do controle. Entretanto, o centro do processo de poder encontra-se no relacionamento entre o Governo e o Parlamento, pois o seu relacionamento é permanente, enquanto a participação do eleitorado não é contínua e a atuação dos Tribunais é limitada. Diante disso, sempre se buscou um equilíbrio entre esses dois Poderes, o que, todavia, jamais aconteceu e dificilmente acontecerá, pois, desde a primeira experiência histórica do Estado constitucional, sempre houve uma oscilação entre a superioridade de um ou de outro (LOEWENSTEIN, 1986, p. 253 - 254).

constitucionais que não podem ser emendadas) e circunstanciais (não se pode emendar a Constituição na vigência de intervenção federal, estado de defesa ou estado de sítio) (FERREIRA FILHO, 2003, p. 185 186).

92 Leis complementares visam dar maior estabilidade para normas que não se quis inserir no texto da Constituição, por meio da exigência de maioria absoluta para sua aprovação. Somente as matérias expressamente previstas na Constituição podem ser objeto dessa espécie legislativa (FERREIRA FILHO, 2003, p. $211-213$ ).

93 Lei ordinária é o ato legislativo típico, caracteriza-se por ser escrito, primário, de iniciativa geral ou reservada, de acordo com a matéria sobre a qual cuide, conforme estabelecido na Constituição. Apresentado o projeto de lei, ele pode ser emendado, sendo vedadas emendas que aumentem a despesa prevista em projetos decorrentes de iniciativa reservada e autorizadas nos demais casos (FERREIRA FILHO, 2003, p. 187 - 202).

${ }^{94}$ Medidas Provisórias são "atos normativos com força de lei editados pelo Presidente da República, em casos de relevância e urgência”. Em tese, só poderiam ser editadas se preenchidas as referidas condições, porém o Supremo Tribunal Federal tem tolerado Medidas que não as preenchem. Sofrem as mesmas limitações materiais que as leis delegadas e ainda outras, possuem um prazo máximo de vigência e limites para reedição, apresentando eficácia imediata após sua publicação. Como são provisórias, para permaneceram em vigor precisam ser convertidas em lei pelo Congresso Nacional (FERREIRA FILHO, 2003, p. $207-210$ ).

95 Lei delegada é um ato normativo elaborado e editado pelo Presidente da República, em razão de autorização do Poder Legislativo, e nos limites postos por este. Não podem ser objeto de lei delegada atos de competência exclusiva do Congresso Nacional, matérias reservadas à lei complementar e normas relativas à organização do Poder Judiciário e do Ministério Público, nacionalidade, direitos individuais, políticos e eleitorais, leis orçamentárias, criação e majoração de tributos, entre outras. $O$ ato de delegação se expressa por meio de resolução do Congresso Nacional, especificando o conteúdo da delegação e os termos para seu exercício, ou seja, indicará a matéria sobre a qual deverá versar a lei delegada e o prazo durante o qual será lícito ao Presidente editar normas sobre essa matéria. O Poder Legislativo pode revogar a delegação a qualquer tempo ou legislar sobre a matéria que delegou (FERREIRA FILHO, 2003, p. 203 - 207).

${ }^{96}$ Decretos legislativos e resoluções são normas individuais editadas pelo Congresso Nacional, que não requerem sanção presidencial. Os primeiros se referem às matérias previstas no artigo 49 da Constituição Federal e as últimas, por exclusão, às que não estão previstas no mencionado dispositivo nem se encontram no âmbito das leis (FERREIRA FILHO, 2003, p. 213 - 215).

${ }^{97}$ Cf. MORAES, 2005, p. 587 - 624. 
O controle exercido pelo Parlamento sobre o Executivo apresenta um caráter externo $^{98}$ (o órgão de controle não integra a estrutura controlada, razão pela qual tende a ser mais independente) e político ${ }^{99}$, abrangendo os atos dos dirigentes eleitos do Governo e também os da burocracia (RIBEIRO, 2002, p. 58 - 62).

Com o fenômeno da delegação legislativa e o declínio da função legislativa do Parlamento, o controle político passa a ser sua principal atribuição, apresentando cada vez maior relevância ${ }^{100}$.

Neste sentido, Bonavides (2004, p. 285) assevera que se o plenário das assembléias parlamentares já não é o recinto da oratória
brilhante dos tribunos que lá buscavam consenso para as idéias em vez de
compromisso para os interesses, como agora impõe a complexidade legislativa
contemporânea, as casas da representação nacional podem perfeitamente
funcionar com todo o prestígio e majestade de suas prerrogativas caso exerçam
sobre a lei, nascida em grande parte de fontes executivas e extraparlamentares
(grupos de pressão), um controle realmente eficaz, extensivo por igual à política
do governo, cujos atos fundamentais encontram ali um fórum de debates onde a
Nação venha a sentir-se presente, falando pelos seus legítimos representantes. Não se pode compreender o controle político exercido pelo Parlamento, dentro da perspectiva do Estado Democrático de Direito, simplesmente, como contenção do poder pelo poder. Muito menos se pode reduzir tão importante papel institucional à apuração de irregularidades e punição de atos de corrupção. O papel do Parlamento, submetido ao controle popular, tal como definido no primeiro item deste capítulo, é direcionar as ações do Estado para a concretização dos direitos humanos sociais e econômicos. Para tanto, estabelecendo um permanente canal de comunicação com o povo (tema do Capítulo 3), o Parlamento deve estabelecer a orientação política do Governo, mesmo dentro do sistema Presidencialista, mediante a edição de normas que fixem diretrizes e metas essenciais a serem atingidas, inclusive em matéria de política econômica, a partir dos direitos e das

\footnotetext{
${ }^{98}$ Cf. LOEWENSTEIN, 1986, p. 252 e Camargo e Kain, 1995.

${ }^{99}$ Ao lado do controle político sobre a Administração existe o jurídico promovido pelo Poder Judiciário, o social, exercido diretamente pela sociedade (por meio de representações, denúncias e ajuizamento de ações populares), e o exercido pelas entidades de fiscalização superior, no caso brasileiro, pelos Tribunais de Contas (RIBEIRO, 2002, p. $59-60$ ).

${ }^{100}$ Cf. Schwartz, 1966, p. 74. Na opinião de Ferreira Filho (2003, p. 159 - 160), o controle é mais eficaz nos sistemas parlamentaristas, nos quais por meio de "moções de desconfiança" aprovadas pelo Parlamento, um ministro ou até o Gabinete inteiro podem cair, do que no presidencialismo, em que é mais limitado. No mesmo sentido, há a posição de LOEWENSTEIN (1986, P. 253), para quem os controles entre órgãos se operam de maneira mais eficiente no parlamentarismo, onde há interdependência por integração, sendo também eficazes, porém em menor grau, no presidencialismo americano, e débil onde há governo de assembléia. Em sentido contrário, Medauar (1990, p. 113) aponta a opinião de Debbasch (Science Administrative, p. 634).
} 
linhas gerais previstos na Constituição (e estabelecidos pelo povo). Depois disso, competelhe a fiscalização do cumprimento de suas orientações, tornando transparentes as ações do Executivo e submetendo-as ao debate público, de maneira que se constitua um verdadeiro espaço público ${ }^{101}$ para definição democrática dos rumos do Estado. Na hipótese de não cumprimento de suas diretrizes e de não se atingirem injustificadamente as metas, o Parlamento deve dispor de mecanismos para aplicação de sanções e outras medidas corretivas $^{102}$.

O fundamento para esta primazia do Parlamento se encontra, primeiramente, no fato de ser o único órgão do Estado que representa a diversidade de idéias e interesses presentes na sociedade. Em segundo lugar, acompanhando o posicionamento de Schwarts (1966, p. 96 - 7), como "tôda autoridade exercida pelo Executivo deve provir de algum ato legislativo", pois a "teoria jurídica anglo-americana rejeita a concepção de poder autônomo ou inerente ao Executivo", se o Executivo não exercer as atividades que lhes foram delegadas de acordo com a vontade do Congresso, este pode modificar ou revogar a delegação.

Em termos de políticas sociais, o Parlamento dispõe (e como se verá, tem feito uso) de uma ampla competência legislativa. Todavia, a concretização desses direitos depende de dois fatores: a política econômica e a definição e aplicação do orçamento público. Quanto ao primeiro, como se verá no próximo capítulo, o Parlamento se encontra quase que totalmente excluído. No que se refere ao orçamento público ${ }^{103}$, trata-se do

\footnotetext{
${ }^{101}$ Por espaço público, em um Estado Democrático de Direito, Ribeiro (2002, p. 67) entende o espaço onde "se exerce a plena cidadania. Abrange desde o exercício dos direitos e garantias (individuais e sociais) até a preservação e utilização de Bens Públicos de uso comum, exclusivos ou dominiais, bem como o cumprimento dos deveres para a Sociedade e a Coletividade, representadas pelo Estado". E acrescenta: "a construção do Espaço Público pressupõe a existência de uma ética que valorize a solução coletiva e a construção da Sociedade com relações que se baseiam na cidadania e na igualdade. Pressupõe, também, a clara distinção de esferas de atuação pública e privada, onde a esfera pública trata da consecução do bem comum".

${ }^{102}$ Em sentido contrário a este posicionamento, ver Ferraz (1993, p. 238 - 247), que, apegada à rigidez do princípio da separação de poderes, restringe bastante o campo de atuação do controle parlamentar, limitandoo ao aspecto de contenção, e não admitindo a anulação de atos do Executivo pelo Legislativo, nem o redirecionamento da orientação política do primeiro pelo segundo.

${ }^{103}$ Schwartz (1966, p. 97 - 98) acentua a importância do controle exercido pelo Congresso norte-americano sobre as despesas do Executivo, as quais precisam ser autorizadas por ele. Entretanto, na maioria dos casos esse controle não é muito rigoroso, sendo "mais uma questão de formalidade do que de substância". Assim, é necessário um controle exercido por um pequeno número de parlamentares especializados. Nesse sentido, estabeleceu-se que cada comissão permanente deve exercer uma vigilância constante sobre a execução das leis pertinentes à sua área temática. Porém, sabe-se que essa fiscalização não resolve completamente o problema, diante do que já se chegou a propor a adoção do sistema parlamentar britânico Nesse sentido Camargo e Kain (1995, p. 215) ressaltam que a utilização de informações obtidas na análise das contas do governo podem ser utilizadas pelo "Congresso Nacional, pela administração pública e pelos grupos de interesse" não só para punições, mas principalmente para correções nas práticas administrativas.
} 
principal mecanismo de direcionamento das ações do governo de que o Parlamento dispõe, todavia, como se verá no capítulo seguinte, ele também sofre grandes limitações ${ }^{104}$.

Assim, os instrumentos de controle relacionados à fiscalização dos atos do Executivo pelo Parlamento constituem um mecanismo complementar à sua primeira forma de atuação que é a fixação das metas e diretrizes. Desta maneira, sem a definição da orientação política do Estado pelo Parlamento, sua atuação fiscalizadora perde grande parte de seu valor. Por outro lado, de nada adianta a clara definição das metas e diretrizes sem uma eficiente fiscalização ${ }^{105}$ e sem os mecanismos de correção e sanção no caso de seu descumprimento.

O estudo sobre os limites e as possibilidades da atuação do Parlamento no controle democrático do poder político será o objeto do próximo capítulo. Todavia, nas linhas que se seguem, far-se-ão algumas considerações sobre os instrumentos de fiscalização e sanção dos quais dispõe o Parlamento ${ }^{106}$.

O controle parlamentar por meio da fiscalização ${ }^{107}$ apresenta duas espécies: político-administrativo e financeiro-orçamentário. Pelo primeiro, o Legislativo pode questionar os atos do Executivo, acompanhando o seu funcionamento e suas ações, analisando a sua atuação e tomando as medidas que julgar necessárias, como a instauração de Comissões Parlamentares de Inquérito. Já o segundo controle consiste na "fiscalização contábil, financeira, orçamentária, operacional e patrimonial da União e das entidades da administração direta e indireta, quanto à legalidade, legitimidade, economicidade, aplicação de subvenções e renúncia de receitas"108 (MEDAUAR, 1990, p. 379 - 380) ${ }^{109}$.

\footnotetext{
${ }^{104}$ Camargo e Kain (1995, p. 217 - 221 afirmam que "instrumento mais poderoso para analisar e controlar a utilização dos recursos públicos é a apreciação do orçamento público da União". Entretanto, ele não é utilizado de maneira satisfatória pelo Parlamento, nem na fase de elaboração nem na de fiscalização da execução orçamentária.

105 Por exemplo, Temer (2001, p. 132) afirma que a Constituição Federal confere o mesmo grau de importância para à função legislativa e à fiscalizadora, sendo a última uma decorrência do fato de os parlamentares representarem a população, a qual tem o direito de fiscalizar as ações dos Poderes do Estado. Ao terem acesso aos atos praticados pelo Executivo, os parlamentares podem apresentar críticas, elogios e tomarem medidas como, por exemplo, convocação de autoridades para prestarem esclarecimentos e ajuizarem ações populares contra atos que prejudiquem o patrimônio público.

${ }^{106}$ Camargo e Kain (1995, p. 211 - 212) salientam que o principal problema desses instrumentos de controle é o fato de serem acionados quando um problema já existe e não de forma preventiva.

107 A atividade de fiscalização do Poder Legislativo sobre a Administração Pública recebe diferentes denominações da doutrina: "controle político", "controle legislativo" e "controle parlamentar". Medauar (1990, p. 111 - 112) prefere a denominação "controle parlamentar", ou "controle do Poder Legislativo". A autora ainda limita o conceito às atividades de fiscalização exercidas exclusivamente pelas Casas Legislativas, excluindo-se as realizadas por outros entes teoricamente considerados ligados ao Legislativo, mas que conservam independência institucional e ausência de subordinação hierárquica, como os Tribunais de Contas e os "Ombudsmen".

${ }^{108}$ Cotta $(1995,886)$ aponta os instrumentos mediante os quais o Parlamento exerce o controle político, como a negação da confiança, nos regimes parlamentaristas, e a ameaça de impedir a aprovação de projetos do
} 
Na fiscalização dos gastos públicos, o Parlamento não deve analisar somente a legalidade, mas também “deve considerar tanto a eficiência, eficácia e economicidade do seu uso, quanto critérios de ordem pública, como oportunidade e ética" (CAMARGO E KAIN, 1995, p. 208 - 209).

Medauar apresenta uma comparação entre os instrumentos de controle parlamentar na França, na Inglaterra, nos Estados Unidos e no Brasil.

$\mathrm{Na}$ França, existem os seguintes instrumentos de controle parlamentar: questões, que podem ser orais ou escritas, por meio das quais os parlamentares buscam esclarecimentos sobre a atuação do governo e da administração e têm como objetivo, mais do que propiciar o conhecimento de fatos, pois muitas vezes já são conhecidos, levá-los ao conhecimento da opinião pública; comunicação de documentos que o governo deve fazer ao Parlamento, sobretudo de matérias financeiras e econômicas; autorizações e aprovações diversas para atos ou medidas do Executivo, a serem ou já adotados, podendo, inclusive, revogá-los ou impedir sua eficácia; comissões de inquérito, formadas com a finalidade de investigar fatos determinados e submeter suas conclusões ao plenário e de controle, destinadas a examinar a gestão dos serviços públicos e de empresas estatais; delegações parlamentares, as quais acompanham questões relevantes para o Parlamento e o informam sobre elas; controle da aplicação das leis por meio de estudo das comissões permanentes sobre a atuação do governo na aplicação das leis referentes a matérias de sua competência, apresentação das conclusões em plenário e aplicação de medidas como questões, carta ao ministro competente e publicação das conclusões e propostas. Apesar de dispor de todos esses meios, aponta-se que o Legislativo francês não consegue desempenhar sua função de controle a contento, pois todos eles são pouco utilizados e pouco eficazes, nem dispõe dos meios práticos e jurídicos necessários para tal tarefa (MEDAUAR, 1990, p. 115 - 118).

O controle parlamentar inglês ${ }^{110}$, que segundo os autores Braibant, Questiaux e Wiener, citados por Medauar (1990, p. 118 - 121), é mais eficiente do que o francês,

Executivo ou não aprovar créditos orçamentários no presidencialismo. Entretanto, ressalta que o instrumento mais comum consiste em levar à opinião pública informações sobre o Governo que obtém mediante pedidos de informações e inquéritos. O autor destaca ainda que "um momento importante da função de controle dá-se com a repetição anual da discussão do orçamento", pois "submete à vigilância parlamentar a realidade global do programa anual do Governo e oferece ocasião para um debate geral acerca das finalidades da ação do Executivo".

${ }^{109}$ Cf. CAGGIANO, 2003, p. $159-161$.

110 A propósito do Parlamento inglês, Griffith, Ryle e Wheeler-Booth $(1989$, p. 15 - 17; 34) apontam, primeiramente, que existem diferentes instrumentos para obtenção das informações relevantes para as discussões, como as questões que exigem respostas escritas, questões orais e a atuação das comissões especializadas que analisam detalhadamente os orçamentos e as despesas do Governo, bem como suas ações e os resultados de suas políticas. Sem tais informações seguras, não há possibilidade de ocorrer um debate 
utiliza os seguintes instrumentos: questões escritas, para casos mais minuciosos, e orais, que são feitas durante as sessões do Parlamento e nelas mesmas respondidas pelo Primeiro Ministro (períodos das sessões denominados de "question time"); comissões de inquérito (“Tribunais of iquire”), constituídas por pessoas designadas, mas não vinculadas ao Parlamento, têm forte poder de investigação, e ao final de seu trabalho, produzem um relatório que submetem ao plenário; comissões especializadas ("select committees"), visam à verificação de atividades de determinado serviço e têm poder de convocar testemunhas e de requererem apresentação de documentos; controle da legislação delegada, o qual permite que o Parlamento vigie os regulamentos editados pelo Executivo para o cumprimento das leis.

No entendimento dos mesmos autores citados acima, os poderes de controle do Parlamento norte-americano ${ }^{111}$ sobre a Administração são maiores ainda que os do inglês e se baseiam nos seguintes instrumentos: aprovação do Senado de nomeações do Presidente da República para funções públicas federais, porém, nesse procedimento, embora exista a possibilidade de não aprovação, isso se dá em uma proporção mínima na prática; aprovação de tratados internacionais e da nomeação de embaixadores; comissões permanentes ("Standing Comittes"), as quais são dotadas de poder de investigação e de convocação de funcionários da Administração para darem explicações sobre projetos de lei em tramitação ou sobre atividades de seus órgãos; comissões de inquérito ("Investigating Committes"), as quais têm a atribuição de controlar a Administração por meio de investigações quando ocorre algum fato que justifique tal procedimento, tendo poderes de convocação de testemunhas e de vista de documentos; poder de "bolsa", que consiste na possibilidade de o Congresso limitar créditos orçamentários de determinados setores da Administração (MEDAUAR, 1990, p. 121 - 123).

No Brasil, os principais meios de controle da Administração pelo Parlamento são os seguintes: pedidos escritos de informação, configurando-se crime de responsabilidade a recusa ou não atendimento no prazo estabelecido, bem como a

efetivo. Os debates parlamentares influenciam a maneira como o Governo conduz a administração, bem como a opinião do eleitorado sobre o Governo, pois eles ao mesmo tempo refletem e formam a opinião pública. Além disso, como se trata de um sistema parlamentarista, os Ministros são responsáveis por suas decisões e ações, bem como por aquelas tomadas por seus subordinados.

${ }^{111}$ A respeito do Congresso norte-americano, Schwarts (1966, p. 34 - 35) salienta que, nos Estados Unidos, "a inexistência do princípio da responsabilidade ministerial torna o Executivo livre do controle legislativo direto. Por outro lado, a falta de uma disciplina partidária rigorosa permite que o Congresso se mantenha relativamente livre do domínio do Executivo", de maneira que, apesar do desequilíbrio entre os Poderes em favor do Executivo, "a separação dos poderes, entre o Legislativo e o Executivo, nos Estados Unidos, continua a ser relativamente vigorosa, segundo os padrões ingleses". 
prestação de informações falsas; a convocação para comparecimento de Ministros ou Secretários para prestarem informações pessoalmente sobre assuntos pré-determinados, também se configurando crime de responsabilidade o não comparecimento; a fiscalização de atos da Administração Direta e Indireta; as Comissões Parlamentares de Inquérito; aprovações e autorizações do Executivo, como aprovação de tratados, acordos e atos internacionais, alienação e concessão de terras públicas e outros; também compete ao Senado a aprovação da nomeação pelo Presidente da República de magistrados, como os Ministros do Supremo Tribunal Federal, Presidentes e Diretores do Banco Central, Ministros do Tribunal de Contas e autorizar operações externas de natureza financeira, de interesse da União, dos Estados, do Distrito Federal e dos Municípios, dentre outras atribuições, verificando-se, todavia, que, na prática, dificilmente alguma nomeação é recusada; fiscalização financeira e orçamentária, com o auxílio do Tribunal de Contas (MEDAUAR, 1990, p. 123 - 129). Menciona-se, ainda o poder do Congresso Nacional de sustar atos regulamentares do Executivo, o qual, segundo Ferraz (1993, p. 330 - 331), "constitui figura aberrante, que não se ajusta às lindes do controle político para o qual o Poder Legislativo é naturalmente vocacionado".

No exercício da fiscalização da Administração (e mesmo no trabalho legislativo), o acesso às informações necessárias para o desempenho dessa tarefa é imprescindível, daí a importância dos poderes de investigação ${ }^{112}$ do Parlamento. ${ }^{113}$

Todavia, Carajeloscov (2007, p. 78) ressalva que “os Parlamentos não devem ser transformados em órgãos de investigação exclusivamente: não podem ter suas atividades direcionadas apenas às apurações, mesmo em se tratando de assuntos que estejam sob sua alçada de fiscalização ou produção legislativa", de maneira que os membros do Parlamento devem participar das atividades do plenário, das comissões temáticas, do gabinete e do contato com os representados.

O controle parlamentar, no sentido de fiscalização de irregularidades, tem nas Comissões Parlamentares de Inquérito ${ }^{114}$ seu instrumento mais poderoso. Elas são dotadas de poderes de investigação próprios das autoridades judiciais, tendo seu campo de ação limitado a fatos específicos relacionados ao Poder Público e pelo princípio federativo.

\footnotetext{
${ }^{112}$ Carajeloscov (2007, p. 60) afirma que o "poder de investigar é também decorrência do poder de fiscalizar e controlar".

${ }^{113}$ Schwarts (1966, p. 99) afirma que um dos instrumentos mais importantes do Congresso norte-americano são os seus poderes de investigação, pois somente mediante seu exercício, o Legislativo pode obter as informações necessárias e suficientes tanto para o trabalho legislativo como para a fiscalização do cumprimento das leis.

${ }^{114}$ Cf. CARAJELOSCOV, 2007, p. 68, FERRAZ (1993, p. 273).
} 
Respeitados esses limites, podem: determinar a oitiva de testemunhas; ouvir investigados ou indiciados; determinar buscas e apreensões; realizar perícias e exames; quebrar sigilos bancário, fiscal e de dados, mediante solicitação ao órgão jurisdicional competente. Mas não poderão: decretar prisões, salvo em flagrante delito; determinar a aplicação de medidas cautelares; ou proibir ou restringir a assistência jurídica aos investigados. Eventuais abusos e ilegalidades cometidos pelas Comissões Parlamentares de Inquérito deverão ser controlados pelo Judiciário, mais especificamente pelo Supremo Tribunal Federal (MORAES, 2005, P. $380-389$ ).

Carajeloscov (2007, p. 68) define as comissões parlamentares de inquérito como

órgãos não permanentes do Parlamento, com prazo certo de duração, criados por decisão deste para inquirirem, mediante poderes excepcionais, sobre fato certo de interesse público relevante, com vista ao exercício de uma atividade de fiscalização e controle ou inovação legislativa, ínsita a esse mesmo parlamento.

As Comissões Parlamentares de Inquérito são uma "franquia democrática assegurada à minoria", ${ }^{115}$ pois, nos regimes democráticos, a fiscalização do governo é exercida predominantemente pelas "minorias parlamentares oposicionistas" (CARAJELOSCOV, 2007, p. 76 - 78).

Salienta-se, nesse sentido, que o direito de oposição é imprescindível para a existência de verdadeira democracia, estando presente em vários instrumentos previstos na Constituição Federal ${ }^{116}$ (CARAJELOSCOV, 2007, p. 81)

Apesar de dispor de todos esses instrumentos, as conclusões de uma Comissão Parlamentar de Inquérito resultam somente no encaminhamento de ofícios para as Mesas Diretoras das Casas Legislativas e para o Executivo, recomendando correções (e eventualmente o ajuizamento de alguma ação) e para o Ministério Público, que poderá propor a ação civil e/ou a ação penal competente, quanto entender ser o caso (CAGGIANO, 2003, p. 162). Além disso, as investigações promovidas por uma Comissão Parlamentar de Inquérito podem provocar a edição de normas pertinentes ao assunto investigado (CARAJELOSCOV, 2007, p. 65).

Além de fiscalizar, o Parlamento pode punir infrações político-administrativas. Para tanto, dispõe dos institutos da cassação do mandato de seus próprios membros e do

\footnotetext{
115 Inclusive, a Constituição Federal brasileira, em seu art. 58, $\S 3^{\circ}$, exige o requerimento de somente um terço dos membros de uma ou de ambas as Casas Legislativas para que seja instalada.

${ }^{116}$ Como, por exemplo, a possibilidade de ajuizamento de Ação Direta de Inconstitucionalidade por partido político com representação no Congresso Nacional e a exigência de quórum qualificado para emenda à Constituição.
} 
"impeachment"117 do Chefe do Poder Executivo e de outras autoridades (CAGGIANO, 2003, p. 157).

Observa-se, todavia, que o exercício da função de controle pelo Parlamento, ainda que no sentido de mera fiscalização da Administração Pública, encontra-se diante de um grande paradoxo, pois, por um lado, apresenta alta relevância e, por outro, enfrenta grande dificuldade operacional e seus resultados são escassos ou até inexistentes. Alguns fatores apontados para explicar essas dificuldades são: a própria crise geral da instituição parlamentar diante do crescimento das funções do Estado; a complexidade e o tecnicismo das Administrações modernas; a grande quantidade de atos administrativos a fiscalizar; ausência de sanções a serem aplicadas pelo Legislativo no exercício de seu controle, já que não pode anular ou modificar atos administrativos, ou condenar a Administração ou administradores ao pagamento de indenizações, restando-lhe dar publicidade aos fatos e às suas críticas; a hegemonia do Executivo entre os três Poderes, enquanto dominante da máquina governamental e a conseqüente inexistência de interesse político de o Parlamento realizar um controle concreto e eficaz, não obstante muitas vezes existam os instrumentos legais para isso, para não desagradar o Executivo ${ }^{118}$ (MEDAUAR, 1990, p. 114 - 115), visto que muitos parlamentares dependem dele para se reelegerem.

\subsubsection{Organização do Parlamento.}

Depois de se analisar a função do Parlamento, neste tópico será feita uma breve apresentação sobre a maneira como ele se organiza.

\footnotetext{
${ }^{117}$ Instituto de origem inglesa, o "impeachment" foi desenvolvido especialmente do século XIII à primeira metade do século XVII, sob o fundamento de que "o governante não é o senhor do poder que exerce, mas apenas um delegado ou representante do povo, ou da comunidade, à qual têm que prestar contas". Ele consiste no "processo pelo qual o Legislativo sanciona a conduta da autoridade pública, destituindo-a do cargo e impondo-lhe pena de caráter político". O "impeachment" se encontra previsto na Constituição americana, e nas Constituições brasileiras desde a de 1824. Quanto à sua natureza jurídica, a maioria da doutrina brasileira entende que é política, mas há os que defendem que possui natureza penal e outros que é mista. No que se refere ao seu procedimento, a Constituição Federal (artigos 85 e 52, incisos I e II) prescreve que pode ser movido contra o Presidente e o Vice-Presidente da República, os Ministros de Estado e os comandantes da Marinha, do Exército e da Aeronáutica, Ministros do Supremo Tribunal Federal, O Procurador-Geral da República e o Advogado-Geral da União, no plano federal, e contra as autoridades equivalentes nos estados e municípios. Quem realiza o julgamento na esfera federal é o Senado, sob a presidência do Presidente do Supremo Tribunal Federal, exigindo-se o voto favorável de dois terços de seus membros para a condenação, cuja pena consiste em perda do mandato e na inabilitação, por oito anos, para o exercício de qualquer função pública. Existindo crime comum além do de responsabilidade, a autoridade responderá por ele perante o Supremo Tribunal Federal. Antes do julgamento pelo Senado, é necessária a licença da Câmara dos Deputados para se iniciar o processo, exigindo-se o voto favorável de dois terços de seus membros (FERREIRA FILHO, 2003, p. 161 - 165). Cf. Ferraz (1993, p. 281).

${ }^{118}$ Cf. FERRAZ, 1993, p. 230.
} 
O Parlamento pode ser constituído por somente uma estrutura deliberativa ou por duas. No segundo caso, é denominado de bicameral, pois duas Câmaras distintas aprovam separadamente cada projeto de lei, limitando-se e controlando-se mutuamente ${ }^{119}$ (LOEWENSTEIN, 1986, p. 245).

O Poder Legislativo nacional brasileiro é bicameral, em decorrência da forma federal do Estado ${ }^{120}$. O Congresso Nacional é composto por duas Casas (Câmara dos Deputados e o Senado Federal ${ }^{121}$ ), que realizam sessões separadamente e, em casos excepcionais, de forma conjunta (FERREIRA FILHO, 2003, p. 168 - 169). ${ }^{122}$ Já nos âmbitos municipal e estadual, o Legislativo é constituído por uma única Câmara (MORAES, 2005, p. 373).

As Casas Legislativas são regidas pelas normas constitucionais e por seus regimentos internos por elas mesmas elaborados ${ }^{123}$ e apresentam os seguintes órgãos: mesas diretoras, ${ }^{124}$ colégio de líderes, comissões permanentes, comissões temporárias, comissões parlamentares de inquérito, comissões representativas, polícia e serviços administrativos (SILVA, 2001, p. 513 - 519).

As comissões permanentes são órgãos que se dedicam a matérias específicas, correspondendo, muitas vezes, aos diferentes ramos da Administração. Bonavides (2004, p. 289 - 290) acentua que "o futuro do parlamento como instituição em grande parte se

119 Alguns autores defendem o sistema bicameral argumentando que a existência de duas Câmaras: é indispensável nos Estados Federais para assegurar a autonomia regional; constitui uma garantia contra eventuais abusos de uma única Câmara; possibilita o reexame e maior maturidade na deliberação sobre as matérias propostas, evitando-se os riscos de votações sem a devida reflexão; como a Câmara dos Deputados é mais numerosa do que o Senado e seus membros têm mandato mais curto, existe o risco de se cederem às paixões populares com o objetivo de se garantir a reeleição, o que pode ser compensado pela existência de uma segunda Câmara. Já a favor do sistema de uma só Câmara aponta-se que se baseia na "necessidade da unidade da representação" e é capaz de evitar a concentração de poder, possuindo mecanismos para que não ocorram abusos na atuação parlamentar. Além disso, salienta-se que no bicameralismo: existem "riscos de dispersão" nas relações entre o Parlamento e o Governo e de conflitos entre as duas Câmaras; e o processo legislativo se torna mais lento (PALUDO, 1999, p. 37 - 40).

${ }^{120}$ Existem também sistemas bicamerais de origem aristocrática, como o inglês, no qual uma das Câmaras representa a nobreza (TEMER, 2001, p. 125).

${ }^{121}$ A Câmara dos Deputados apresenta uma primazia sobre o Senado quanto à iniciativa legislativa, pois os projetos de iniciativa dos cidadãos, do Supremo Tribunal Federal, do Superior Tribunal de Justiça e do Presidente da República são apresentados perante ela (a Casa onde se inicia a tramitação do projeto tem a palavra final quanto a modificações introduzidas), embora não exista predominância substancial de uma sobre a outra (SILVA, 2001, p. $512-513$ ).

122 São realizadas Sessões conjuntas nos seguintes casos: inauguração da sessão legislativa; elaboração do regimento comum e regulação da criação dos serviços comuns às duas Casas; para receber compromisso do Presidente e do Vice-Presidente da República; conhecer do veto e sobre ele deliberar; discutir e votar o orçamento.

${ }^{123}$ Cf. FERREIRA FILHO (169 - 170). Schwartz (1966, p. 82) afirma que regulamentar “a sua própria constituição e seus assuntos internos" é uma prerrogativa fundamental do Congresso.

${ }^{124}$ As Mesas do Congresso Nacional, do Senado e da Câmara dos Deputados são seus órgãos de direção administrativa (MORAES, 2005, p. 373). Cf. TEMER, 2001, p. 127. 
acha na dependência da esfera de ação e trabalho das comissões, sobretudo de seus padrões de aperfeiçoamento, tecnicidade e elevação qualitativa" ${ }^{125}$.

No mesmo sentido, Schwarts $(1966$, p. 86 - 88) salienta que "grande parte do importante trabalho do Congresso americano é feita através de comissões”. Isso porque, diante do grande volume de tarefas que lhe foram atribuídas e da urgência requerida para a tomada de decisões, o único meio de realizar seu trabalho é pela confiança na responsabilidade do estudo detalhado dos assuntos e projetos a grupos de parlamentares que compõem comissões permanentes especializadas em determinada área. Todos os projetos passam pelas comissões, antes de serem remetidos ao plenário, as quais os “analisam e selecionam”, sendo dificilmente aprovados sem sua manifestação favorável.

As comissões permanentes podem, ainda, cumprir um papel relevante no controle do Executivo, na medida em que tem competência para receber reclamações de qualquer pessoa e tomar providências (FERRAZ, 1993, p. 260 - 261).

Além da livre organização por seus regimentos internos (submetidos somente à Constituição Federal) e da prerrogativa de serem dirigidos por seus pares, a independência institucional do Parlamento é, juridicamente, garantida por um conjunto de normas constitucionais que estatui o regime jurídico dos parlamentares, denominado de "Estatuto dos Congressistas". Nele estão previstos prerrogativas, direitos, deveres, proibições, impedimentos e incompatibilidades. Dentre as prerrogativas estão as imunidades materiais e formais e o foro por prerrogativa de função. As imunidades e o foro por prerrogativa de função existem para garantir a liberdade do exercício do mandato, sobretudo quanto às opiniões e votos, bem como para proteger os parlamentares contra abusos e pressões dos demais Poderes. Dentre seus direitos está o subsídio, o qual atende a um princípio democrático, pois sem ele somente os ricos poderiam exercer mandatos, ficando excluídos todos os que precisam trabalhar para sobreviver ${ }^{126}$. As proibições e os impedimentos objetivam evitar que o parlamentar se comprometa com interesses distintos de sua função e

\footnotetext{
${ }^{125}$ Nesse sentido, o referido autor (2004, p. 286) pondera: "há assim uma instância crítica em relação a atos políticos dúbios do Executivo, podendo o trabalho daquelas Comissões ter reflexos corretivos imediatos na política do governo, temeroso diante da opinião pública e das repercussões negativas sobre a própria sucessão presidencial". E conclui: "o parlamento livre é, por conseguinte, a instituição que não só controla os governos como confere legitimidade aos sistemas políticos. Aí está todo o seu futuro."

${ }^{126}$ Moraes $(2005$, p. 367 - 369) salienta que as garantias são condições para o próprio exercício independente das funções estatais e a separação de poderes, objetivando a defesa do regime democrático e dos direitos fundamentais, sendo "invioláveis e impostergáveis, sob pena de ocorrer desequilíbrio entre eles e desestabilização do governo". Elas existem para que os parlamentares possam exercer bem suas funções e não ferem o princípio da igualdade de direitos, pois "o que se veda são as diferenciações arbitrárias, as discriminações absurdas, mostrando-nos que o tratamento desigual dos casos desiguais, à medida que se desigualam, é exigência do próprio conceito de Justiça". Portanto as garantias e as imunidades são legítimas perante o próprio princípio da igualdade.
} 
que obtenha benefícios especiais e vantagens indevidas. As incompatibilidades (funcionais, negociais, políticas e profissionais) visam evitar conflitos de interesses. Compõem ainda esse Estatuto as hipóteses de extinção e cassação do mandato do parlamentar. Pode-se perder o mandato nos casos de: violação de algumas das proibições acima referidas; procedimento incompatível com o decoro parlamentar; suspensão ou perda dos direitos políticos; impugnação do mandato eletivo decretada pela Justiça Eleitoral; e condenação criminal em sentença transitada em julgado. ${ }^{127}$

\subsection{Contexto da Análise do Problema: Globalização Capitalista.}

Da mesma maneira que a concepção de controle do poder político adotada nesta pesquisa é muito diferente da predominante nos tempos em que surgiu o Parlamento, o contexto atual, cujo fenômeno central é a globalização capitalista, é bastante diverso da referida época. Assim, analisar se o Parlamento é capaz de exercer eficazmente o controle do poder político, hoje, difere radicalmente de uma apreciação acerca desse problema nos séculos XVII, XVIII, XIX, e mesmo até no início do último quarto do século XX.

Em um sentido bastante amplo, a globalização pode ser compreendida como um processo contínuo que caracteriza a história da humanidade desde as primeiras migrações do Homo sapiens, passando "pelas conquistas dos antigos romanos, a expansão do Cristianismo e do Islã, as grandes navegações da era moderna, a difusão dos ideais da Revolução Francesa, o neocolonialismo do Século das Luzes, ganhando impulso depois da Segunda Guerra Mundial” (LEWANDOWSKI 2004, p. 50).

Nos séculos XV e XVI, com a denominada "revolução copernicana" e a percepção de que a humanidade habitava em um globo, a integração mundial passou a progredir constantemente e sem retrocessos, impulsionada, sobretudo, por interesses comerciais (LEWANDOWSKI, 2004, p. 50).

Após a Revolução Industrial, Marx e Engels (2005, p. 41 - 45), no "Manifesto do Partido Comunista", já observavam que a grande indústria criou e a burguesia passou a explorar o mercado mundial, o qual "acelerou enormemente o desenvolvimento do comércio, da navegação, dos meios de comunicação", provocando, por sua vez, a expansão da indústria. Imprimiu-se, com isso, "um caráter cosmopolita à produção e ao consumo em todos os países", ou seja, a indústria perdeu sua base nacional e surgiram novas demandas

${ }^{127}$ Cf. SILVA (2001, p. 535 - 541), FERREIRA FILHO (2003, p. 175 - 179) e MORAES (2005, p. 415 416). 
a serem satisfeitas por produtos estrangeiros, o que provocou um intercâmbio internacional tanto da produção material como da intelectual. A partir desse fenômeno, do ponto de vista social, a burguesia teria suplantado "todas as classes legadas pela Idade Média" e, na perspectiva política, teria conquistado a "soberania política exclusiva do Estado representativo moderno." Porém, os autores já advertiam que "a sociedade burguesa moderna, que conjurou gigantescos meios de produção e de troca, assemelha-se ao feiticeiro que já não pode controlar os poderes infernais que invocou".

Todavia, foi nos anos setenta e oitenta ${ }^{128}$ do século XX que teve início a globalização contemporânea. Ocorreu, no campo tecnológico, um processo de intensas transformações (especialmente com a revolução da microeletrônica e com a expansão da informática), que diminuíram os custos e aumentaram a agilidade nas comunicações (dando maior liberdade e mobilidade aos agentes produtivos e às instituições financeiras) e, no plano político, o fim da Guerra Fria (FARIA, 2003, p. 7 - 8).

Observa-se, então, segundo Faria (2002, p. 52), o fenômeno da globalização ${ }^{129}$ em sentido estrito, ou seja, uma

integração sistêmica da economia em nível supra nacional, deflagrada pela crescente diferenciação estrutural e funcional dos sistemas produtivos e pela subseqüente ampliação das redes empresariais, comerciais e financeiras em

\footnotetext{
${ }^{128}$ Santos (2000, p. 87) assinala que, já nos anos sessenta, inicia-se um período da história do capitalismo denominado como "capitalismo desorganizado", o qual apresenta as seguintes características: "o crescimento explosivo do mercado mundial, propulsionado por um novo agente criado à sua medida -, torna possível contornar, se não mesmo neutralizar, a capacidade de regulação nacional da economia; os mecanismos corporativos de regulação dos conflitos entre capital e trabalho, estabelecidos a nível nacional no período anterior, enfraquecem e a relação salarial torna-se mais precária, assumindo formas que, na aparência pelo menos, representam um certo regresso ao período do capitalismo liberal; a flexibilização e a automatização dos processos produtivos, combinados com o embaratecimento dos transportes, permitem a industrialização dependente do terceiro mundo e destroem a configuração espacial do aparelho produtivo nos países centrais com a descaracterização das regiões, a emergência de novos dinamismos locais, a ruralização da indústria, a desindustrialização, a subcontratação internacional etc., etc.; a expansão extensiva do mercado corre paralela à sua expansão intensiva com a crescente diferenciação dos produtos de consumo, um certo abandono da grande produção em massa com o objetivo de promover a particularização dos gastos e o aumentos das escolhas; finalmente, a mercadorização e a digitalização da informação abrem perspectivas quase infinitas à reprodução alargada do capital".

${ }^{129}$ Lewandowski (2004, p. 51) afirma que se rata de uma nova etapa na evolução do capitalismo, tornada possível pelo extraordinário avanço tecnológico registrado nos campos da comunicação e da informática. Essa fase caracteriza-se basicamente pela descentralização da produção, que se distribui por diversos países e regiões, ao sabor das conveniências e interesses das empresas multinacionais. Cuida-se, em verdade, de uma nova divisão internacional do trabalho, em que os insumos e a mão-de-obra, notadamente a especializada, circulam com desenvoltura entre os diferentes centros de produção, graças à crescente integração dos mercados. Ianni (1999, p. 252) assinala que "a globalização do capitalismo, como modo de produção e processo civilizatório, propicia o desenvolvimento de relações, processos e estruturas de dominação política e apropriação econômica de alcance mundial". Além disso, o desenvolvimento das tecnologias da eletrônica e da informática intensifica e apressa mudanças, integrações e tensões entre os atores sociais nas diversas partes do mundo. Por fim, ocorre uma "nova configuração histórico-social de vida, trabalho e cultura, desenhando ma totalidade geohistórica de alcance global, compreendendo indivíduos e coletividades, povos, nações e nacionalidades, culturas e civilizações".
} 
escala mundial, atuando de modo cada vez mais independente de controles políticos e jurídicos nacionais.

Além dos fatores já mencionados, foram fundamentais para a globalização o estabelecimento de um padrão monetário uniforme, ${ }^{130}$ e o fim do controle sobre o movimento de capitais, a liberação das taxas de juros e a liberalização dos mercados de ações, inicialmente nos Estados Unidos e na Inglaterra, depois por todo o mundo. Assistiase, nos anos oitenta do século XX, à transformação da globalização financeira "no carro chefe das transformações capitalistas", e à universalização da "revolução neoliberal, promovendo por todos os lados a desregulação e a abertura das economias nacionais, permitindo que a globalização financeira alcance uma dimensão territorial sem precedentes, mesmo quando não inclua a maior parte dos estados nacionais" (FIORI, 1997, p. 91).

A adoção das idéias neoliberais pelos Estados da periferia do capitalismo deuse, inicialmente, como condições indispensáveis impostas pelas instituições financeiras internacionais para a renegociação das dívidas externas e para seu retorno ao sistema financeiro internacional, sendo, posteriormente, incorporadas pelos intelectuais e pelas coalizões políticas eleitas para governar tais Estados. Entretanto, a adoção das idéias neoliberais ${ }^{131}$ não atingiu os objetivos esperados, de maneira que o receituário do "Consenso de Washington" se encontra totalmente ultrapassado em virtude de seu fracasso nas esferas econômica e social. ${ }^{132}$

O atual período de globalização apresenta algumas características distintivas de outras experiências históricas de integração econômica mundial. A primeira delas são as profundas mudanças nas escalas de tempo e espaço decorrentes das novas tecnologias de informação e comunicação, o que possibilitou uma intensidade nunca antes vista de relações entre Estados. Outra novidade é a maneira como a "globalização hegemônica" tem destruído as promessas de progresso, bem como o desejo de luta por elas,

\footnotetext{
${ }^{130}$ Esse processo, que se iniciou no Mercantilismo, passou pelo estabelecimento do padrão ouro, o qual vigorou até a Primeira Guerra Mundial, e culminou no estabelecimento em Bretton Woods, no ano de mil novecentos e quarenta e quatro do padrão dólar e do regime de câmbio fixo. A partir de mil novecentos e setenta foi abandona a paridade entre o dólar e o ouro e, na atualidade, o sistema de Bretton Woods se revela obsoleto (LEWANDOWSKI, 2004, p. 52 - 59).

${ }^{131}$ A propósito da incorporação das idéias neoliberais nos Estados da América Latina, é preciso salientar que os desequilíbrios orçamentários aqui ocorridos não decorreram de excesso de gastos com políticas sociais na década de 80 e nas anteriores, pois quase não existiam, nem de pressões democráticas, pois tais Estados estavam saindo de períodos autoritários (FIORI, 1997, p. 122). Além disso, destaca-se que a implantação da política econômica neoliberal conseguiu reduzir a inflação em "todos os países desenvolvidos e em alguns em desenvolvimento, mas a um pesado preço: a riqueza concentrou-se nas mãos de poucos e os índices de desemprego aumentaram vertiginosamente. E, o que é pior, a economia não voltou a crescer" (LEWANDOWSKI, 2004, p. 63).

${ }^{132}$ Cf. FIORI, 1997, p. 121 - 122 e LEWANDOWSKI 2004, p. 66 - 69.
} 
deslegitimando projetos alternativos de futuro orientados pela idéia de emancipação social. Além disso, há uma forma inédita de globalização das finanças, viabilizada pelas políticas liberais de desregulação dos mercados. ${ }^{133}$

A transnacionalização dos mercados vem acompanhada (e antecedida) por mudanças jurídicas e institucionais, que objetivam a garantia do funcionamento da economia globalizada, e pela pressão de organizações e corporações econômicas transnacionais, que procuram condicionar ou controlar as decisões dos governos sobre a economia a fim de defender seus interesses expansionistas ${ }^{134}$.

Essas considerações demonstram que "as relações entre o poder político e o poder do dinheiro constituem-se no núcleo gerador da energia que move a globalização". Ou seja, "foram políticas as decisões dos estados nacionais que aplainaram o caminho da

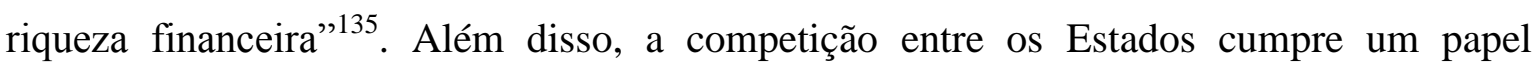
decisivo "nos processos simultâneos de centralização do poder e do capital” (FIORI, 1997, p. 92).

Capitalismo e Estado nasceram juntos, e aliança entre poder político e poder econômico, apesar de ser marcada por instabilidades, é "indispensável e frutífera para os donos do dinheiro tanto quanto para os donos do poder político" (FIORI, 1997, p. 135).

Diante disso, Grau (2008, p. 271) pondera que

essa globalização financeira não pode ser tomada como conseqüência inevitável do progresso científico e tecnológico. A globalização financeira que aí está é fruto de uma política de globalização ancorada na ideologia neoliberal, conduzida, conscientemente desenvolvida pelas instâncias que comandam o mundo (EUA, FMI, Banco Mundial, OMC, OCDE, G-7, etc.) que hoje determinam a produção da ideologia.

Portanto, como assevera Fiori (1997, p. 140), o enquadramento dos países periféricos no processo de globalização não é "obra automática" desse fenômeno, mas

${ }^{133}$ Cf. SANTOS (2002, p. 17) e FIORI (1997, p. $\left.89-90\right)$.

134 Cf. FARIA, 2002, p. 15e DUVERGER, 1975, p. 138 - 148. Duverger aponta que a ação de tais oligarquias econômicas se vale de diferentes métodos, como: financiamento de campanhas eleitorais; grupos profissionais de pressão; desenvolvimento de tecnoestruturas privadas para facilitar o entendimento entre os técnicos da Administração Pública e os do setor privado, os quais compartilham da mesma formação, da mesma linguagem e dos mesmos interesses (aumentar seu prestígio, renda e poder); corrupção de políticos e funcionários que exercem funções estratégicas; conluio entre a municipalidade e empresas prestadoras de serviços e construtoras. Quanto à influência das oligarquias econômicas não eleitas sobre os governos Elster (2007, p. A25) pondera que "numa economia de mercado há restrições às ações do governo, porém não se pode fazer generalizações quanto ao seu alcance, pois variam em cada país e contextos políticos".

${ }^{135}$ Observa-se, por isso, a preocupação dos países desenvolvidos e do poder econômico em assegurar que os burocratas dos Bancos Centrais estejam alinhados com o pensamento econômico hegemônico. Assim, os Bancos Centrais “deixam de ser instrumentos de sues estados mas mantêm-se como 'garantidores' das parcelas de riqueza privada dentro de duas jurisdições bancárias” (FIORI, 1997, p. 139 - 140; 143). 
fruto de decisões políticas que "adotaram estratégias de estabilização e liberalização econômica apoiadas na globalização financeira e abrindo mão, conscientemente, do controle de suas políticas monetária e fiscal e colocando seus objetivos macroeconômicos acima de qualquer outro objetivo nacional". Entretanto, "feita esta opção, segue-se uma lenta e progressiva erosão da soberania interna das autoridades destes países”.

A erosão da soberania ${ }^{136}$ dos Estados, em virtude da globalização, se revela na drástica redução de sua capacidade de atuação em matéria econômica ${ }^{137}$ (juros, câmbio, política fiscal, distribuição de renda, concretização de direitos sociais, oferta de moeda e de emprego ${ }^{138}$ (FARIA, 2003, p. 7 - 8).

No campo da política fiscal, o "turismo fiscal incontrolado" provoca a perda do controle sobre o valor da tributação pelos governos democraticamente eleitos, em favor dos negociantes de produtos e capitais, os quais "estabelecem qual a contribuição que desejam dar para o atendimento de encargos estatais”. Além da perda de receitas, a "economia sem fronteiras" acarreta o aumento das despesas do Estado com subvenções para os grandes conglomerados empresariais ${ }^{139}$. Com isso, os Estados acabam contribuindo com a concentração de renda, ao invés de distribuí-a ${ }^{140}$ (MARTIN e SCHUMANN, 1997, p. $279-280 ; 286)$.

\footnotetext{
${ }^{136}$ A propósito desse assunto, Santos (2000, p. 88 - 89) afirma que o Estado nacional "parece ter perdido em parte a capacidade e em parte a vontade política para continuar a regular as esferas da produção (privatizações, desregulação da economia) e da reprodução social (retraç̧ão das política sociais, crise do Estado-Providência)". Entretanto, "a fraqueza externa do Estado" é compensada pelo aumento de seu autoritarismo, por meio do despotismo da burocracia manifestado em inúmeras pequenas escalas decisórias, ao que se combina na ineficiência do Estado.

${ }^{137}$ Nesse sentido, Faria (2002, p. 324) salienta que graças à desverticalização da produção, à mobilidade espacial e às estruturas flexíveis das instituições financeiras e dos conglomerados empresariais, o que levou o Estado-nação a perder parte do controle sobre as flutuações monetárias e sobre os fluxos de capitais, o poder econômico gradativamente se sobrepôs ao poder político, bem como propiciou o aparecimento de novas formas de ordem baseadas em negociações contínuas, no consentimento tácito, nas autorizações difusas, no prevalecimento dos interesses do ator mais forte no âmbito da cadeia produtiva etc.

${ }_{138}$ Diante disso, Faria (2002, p. 23) salienta que, embora conservando formalmente sua soberania, muitos Estados se mostram incapazes de "estabelecer e realizar seus objetivos exclusivamente por si e para si próprios".

139 A propósito deste assunto Martin e Schumann (1997, p. 285 - 286) afirmam que "os planejadores neoliberais do Instituto de Economia Mundial de Kiel passaram a utilizar uma metáfora tirada do reino da biologia para definir o novo papel do Estado. Este ficaria somente com a função de "hospedeiro" para a economia transnacional, conforme consta de um estudo da entidade. Isso significa, inversamente, que as empresas mundialmente entrelaçadas vão adquirindo características cada vez mais parasitárias. Suas mercadorias utilizam o transporte ferroviário subsidiado, os empregados mandam os filhos para as escolas públicas e os executivos se aproveitam da boa urbanização dos bairros ricos. Só contribuem, porém, com impostos sobre salários, e dos salários pagos saem os impostos sobre o consumo de seus empregados e operários. Como os rendimentos do trabalho tendem a cair, despenca a arrecadação do Estado, que se torna vítima de uma crise financeira estrutural".

${ }^{140}$ Além da política social, em nome da concorrência pela geração de empregos e pela instalação de empresas, "a política do meio ambiente também é sacrificada" (MARTIN e SCHUMANN, 1997, p. 292).
} 
Os Estados também perdem a capacidade de regular eficazmente o valor de sua moeda $^{141}$ em relação às demais e as taxas de juros. Isso ocorre porque a ausência de regulamentação dos mercados financeiros internacionais e as tecnologias que permitem a rápida transferência de capitais de um país para outro asseguram a livre circulação dos capitais em busca da melhor remuneração. Esse capital especulativo, desvinculado da economia real (produção), "é aplicado em bolsas de valores ou de mercadorias e futuros por investidores interessados em obter o maior lucro no menor espaço de tempo" (LEWANDOWSKI, 2004, p. 70 - 71).

Além disso, como assinala Eros Grau (2008, p. 274 -275), justamente "no momento em que o Estado se atribui a responsabilidade pela performance das economias nacionais", ocorre uma "deterioração da capacidade estatal de por o direito (= direito posto)", pois "os mercados financeiros globalizados passam a ser regulados por outros sujeitos que não o Estado".

Isso se explica, em primeiro lugar, porque, no mercado globalizado, os preços de muitos bens e serviços são determinados internacionalmente, os fluxos de capitais não são controláveis pelos Estados e as decisões dos atores internacionais influenciam diretamente os nacionais sem que nada possa ser feito para evitá-las (FARIA, 2003, p. 9 10).

Em segundo lugar, nota-se que as decisões tomadas no campo da economia se dão no que se denomina de tempo real (instantaneamente), enquanto as decisões estatais se processam no tempo diferido (FARIA, 2003, p. 10).

Ressalta-se, ainda, que enquanto a globalização apresenta um caráter internacional, a regulação jurídica estatal é restrita à circunscrição de seu território (GRAU, 2008, p. 276).

Tais considerações deixam claro que a globalização apresenta grande impacto sobre a questão da soberania. Nesse sentido Lewandowski (2004, p. 254) salienta que de fato, pela primeira vez desde que se consolidou como summa potestas no
plano interno e internacional, em especial a partir da Paz de Westphalia, o
Estado não consegue mais controlar de forma satisfatória a repercussão
doméstica das variáveis econômica geradas externamente. Em outras palavras, o

\footnotetext{
${ }^{141}$ Einchengreen (2000, p. 25; 184 - 185) recorda que, no início do século XX, a universalização do sufrágio universal masculino, o fortalecimento dos sindicatos e dos partidos trabalhistas parlamentares trouxeram a formulação de políticas monetárias e fiscais para a "arena político-partidária". Entretanto, "o permanente desenvolvimento dos mercados financeiros, alavancados pelos progressos nas telecomunicações e nas tecnologias de processamento da informação, prejudicou os esforços para conter os fluxos financeiros internacionais".
} 
poder de autodeterminação das comunidades políticas organizadas em Estados passou a ser cerceado pelo poder dos agentes econômicos transnacionais, com o que ficou abalada a própria legitimidade dos governantes ${ }^{142}$.

Todavia, Lewandowski (2004, p. 300) conclui:

Com os olhos voltados para o processo de globalização e o de regionalização, que constituem fenômenos que se integram e complementam, muitos vaticinam o fim ou a revitalização da soberania e, até mesmo, o desaparecimento do Estado. Nada indica, todavia, que isso irá acontecer num futuro próximo. Embora os Estados possam ter eventualmente a autonomia cerceada em alguns aspectos, a sua soberania, ao menos no que ela tem de essencial, não se vê afetada. Na realidade, jamais um Estado, por mais poderoso que fosse, logrou subtrair-se integralmente aos condicionamentos de natureza jurídica ou de ordem fática. A idéia de soberania sem limites, aliás, nunca existiu, muito menos tem lugar nos dias atuais, sobretudo porque as transformações históricas pelas quais os Estados passaram fizeram com que ela acabasse ficando mais flexível do que a noção legada pela tradição.

A globalização, além de provocar forte impacto na soberania do Estado, atinge o universo da política como um todo.

Em primeiro lugar, observa-se uma diferença radical entre o tempo da economia e o da política. Na economia, a velocidade dos fluxos de capitais e das decisões reduz as possibilidades de reflexão sobre o futuro, de maneira que tudo se passa em um “presente contínuo". Já a atividade política, por exigir debates, eleições, deliberações e complexas negociações, passa-se em médio e longo prazos, nunca em tempo real. Assim sendo, quanto mais avança a predominância do tempo real sobre o tempo diferido na economia globalizada, menor se torna a capacidade de controle da política sobre a economia. Além disso, "a reflexão sobre o futuro propiciada pela política e os processos de filtragem de expectativas, aprendizagem cívica e legitimação institucional a ela inerentes são substituídos pelo cálculo objetivo das oportunidades no presente" (FARIA, 2003, p. $11)$.

Outra consequência dos processos sociais em tempo real e da comunicação virtual é o aumento da dependência da política em relação à grande mídia para o estabelecimento do diálogo entre representantes e representados. Porém, como os meios de

${ }^{142}$ O autor (2004, p. 255) acrescenta que "a obsolescência do sistema de Bretton Woods, a inoperância das organizações multilaterais de comércio e a imposição de programas neoliberais de governo aos países pobres acabaram agravando a impotência dos Estados para controlar os impactos locais das decisões dos agentes externos". 
comunicação são controlados por grandes conglomerados econômicos, as informações também são controladas por elites não representativas que direcionam o debate político, formando a opinião pública segundo a ideologia que lhes interessa. Priva-se o público do acesso ao real confronto de idéias, reduzindo-se sua consciência sobre os conflitos que caracterizam a sociedade à preocupação com problemas pessoais. A argumentação lógica é substituída por imagens, desestimulando-se a crítica e reduzindo-se a capacidade de discernimento e julgamento dos cidadãos. Consequentemente, “eles, que já haviam perdido o poder substantivo de dar sentido e limites à economia por meio de procedimentos democráticos, perdem agora a efetiva capacidade de dar sentido à realidade política" ${ }^{\text {"143 }}$ (FARIA, 2003, p. 13 - 14).

Observa-se, também, que embora a internet e a expansão das telecomunicações tenham propiciado maior integração do mundo do ponto de vista econômico, nos aspectos político e social o que se deu foi uma maior fragmentação. Isso se deve à progressiva substituição da proximidade física pela interação virtual o que conduz a isolamentos sociais. Como a política e a representação exigem relações diretas entre sujeitos, diálogo e contato, o relacionamento virtual e o isolamento social enfraquecem a política e a democracia. A participação política e o interesse pelos assuntos públicos diminuem, e o tempo real reduz a capacidade de atuação de partidos e líderes políticos na organização e na canalização das demandas da sociedade, já que sua ação é lenta devido às necessidades de negociação e articulação ${ }^{144}$ (FARIA, 2003, p. 12).

A globalização também provoca um desequilíbrio entre os Poderes, pois as decisões referentes à regulamentação do mercado estão cada vez mais concentradas no Poder Executivo ${ }^{145}$, em virtude da necessidade de se dar respostas rápidas aos investidores, sem que o Legislativo ou o Judiciário sejam consultados, porque os processos decisórios no âmbito desses dois Poderes são demasiadamente lentos por natureza (FARIA, 2003, p. 11). Consequentemente, decisões que atingem amplos setores da economia são tomadas de maneira difusa, sem a consideração global dos interesses, típica da democracia mediante

\footnotetext{
${ }^{143}$ Trabalhando com o predomínio do sensacional sobre o essencial, informações imprecisas e em grande quantidade, de maneira a dificultar a reflexão crítica, a oligarquia econômica também procura desenvolver uma cultura comum que favorece o consenso social apoiado na idéia de um sistema globalmente inevitável, o que desestimula o debate, o questionamento à ordem estabelecida e a imaginação de outras formas de organização social (DUVERGER, 1975, p. 151 - 153; p. 157 - 164).

${ }^{144}$ Cf. FARIA, 2002, p. 29 - 30. O autor ainda pondera que "se representar significa uma relação entre sujeitos, por meio de um diálogo e de um mandato, quanto mais intensa for essa vinculação eletrônica e quanto maior o isolamento social por ela produzido, maior será a fragmentação das identidades coletivas e mais intensa tenderá a ser a velocidade de empobrecimento qualitativo dos mecanismos de participação e representação políticos".

${ }^{145}$ Cf. LAMOUNIER, 1996, p. $54-55$.
} 
negociações (sem transparência e não submetidas ao controle dos representantes eleitos no Parlamento) entre o governo e as corporações (FARIA, 2002, p.25 - 27).

Coloca-se em questão o próprio sentido, o alcance e a efetividade da democracia representativa e da representação parlamentar, pois a transformação das corporações empresariais conectadas globalmente em centros de poder provoca a perda da centralidade do sistema político na organização da sociedade, sendo substituído pelo mercado como fator determinante, já que a economia pauta a agenda e as decisões políticas e jurídicas $^{146}$ (FARIA, 2002, p. 28; p. 35).

Dá-se, também, a redução das obrigações públicas “ao conceito geral de mercadoria", provocando

um esvaziamento dos valores públicos e um "rebaixamento" qualitativo da cidadania, acompanhado da perda de referências éticas e morais e da destruição de laços de referência. Isto, porque, quem está desempregado, em princípio, fica sem acesso ao mercado consumidor. E por esse motivo, não é capaz de ser dono de si, juntamente com os outros, em tudo mais na vida política, social e cultural (FARIA, 2003, p. 9).

Dessa maneira, embora os procedimentos democráticos permaneçam com eleições periódicas, voto livre e alternância de poder, são

esvaziados de sentido e conteúdo, já não são mais um processo compartilhado de afirmação da vontade coletiva e de participação efetiva na constituição do poder. Quando muito, limitam-se a ratificar acordos feitos em outras arenas, inter ou transnacionais, inter ou supragovernamentais, assumindo assim a forma de ritos banalizados e empobrecidos, de jogos de cena determinados pela conjugação entre pesquisa de mercado e técnicas de marketing e de "vídeo política" e espetáculos midiáticos para o imaginário das massas, convertendo o cidadão em mero telespectador, um homo videns banalizado - e, com isso, levando à substituição de seus esforços de reflexão e crítica pela dinâmica passiva dos reflexos (FARIA, 2003, p. 14).

Esse contexto leva a diversos questionamentos apresentados por Faria (2002, p. 31):

como, por exemplo, podem os eleitos num pleito democrático cumprir seus compromissos com os eleitores, uma vez que os mecanismos de controle do movimento dos capitais reais e financeiros no espaço territorial e os instrumentos de implementação e execução de políticas públicas à sua disposição têm sido

\footnotetext{
146 Além disso, a "redução forçada dos orçamentos públicos rebaixa os políticos à condição de meros administradores da penúria. Diante do poder maior do avanço econômico, eles não podem mais arcar com a responsabilidade pela miséria, e isso compromete a estrutura do Estado democrático" (MARTIN e SCHUMANN, 1997, p. 288).
} 
enfraquecidos em seu poder de enforcement pela globalização econômica? A quem e de quem cobrar responsabilidade? Como exercer a accontability? Que mecanismos, enfim, podem assegurar o controle sobre os governantes e sua responsabilidade na nova ordem internacional?

Em outro trecho, o autor (2002, p. 219 - 222) continua:

como preservar o "conteúdo essencial" do ato de votar? Qual o sentido prático em votar e ser votado, uma vez que a representação baseada na regra da maioria já não mais se converte necessariamente em poder substantivo? Por que militar em partidos, disputar eleições e atuar no Parlamento, se o alcance do controle da esfera pública sobre a economia foi drasticamente reduzido pela revogação dos monopólios estatais, pelos programas de privatização e pelas delegações de competência do setor público à iniciativa privada? Pode a regra da maioria resistir ao movimento de transnacionalização das fontes do direito? Posto em outros termos, de que modo restabelecer a subordinação do econômico ao político, ou seja, a submissão dos capitais e decisões dos conglomerados empresariais e financeiros aos interesses da sociedade, expressos pela regra da maioria? De que maneira recompor o papel diretivo do Estado, assegurando-se a participação da cidadania na formulação, implementação e execução da política macroeconômica? Como impedir que os processos de "desconstitucionalização" e "deslegalização" abram caminho para o enfraquecimento dos direitos fundamentais? Em suma: poder-se-ía continuar no 'participacionismo' uma conditio sine qua non da legitimidade democrática, tema tão recorrente na agenda política dos anos 60 e 70, se, a partir da década de 80, a razão instrumental e o saber técnico subjacente às "organizações complexas", exponenciadas pelo fenômeno da globalização açambarcaram as decisões econômicas fundamentais? ${ }^{147}$

Além desses problemas de ordem política, a globalização provocou um grande crescimento da concentração de poder econômico (principalmente nas áreas da tecnologia e da capacidade de investimento) e renda. ${ }^{148}$

147 A essas questões, os teóricos do "direito reflexivo" mencionados por Faria (2002, p. 222 - 226) respondem que não implicam a negação da democracia e da política, mas indicam a necessidade de sua reconceituação e revisão a partir da realidade que se apresenta, o que se daria a partir da "democracia organizacional", a qual não tem seu centro na cidadania, mas sim no espaço da produção e a partir deste atinge os demais, e se baseia na "reflexão", na "responsabilidade social" e na "consciência global". No entanto, o autor aponta sérias limitações nessa teoria, como a tentativa de "converter em relações de fato o que são meras suposições, expressões de valor e desejo". O supracitado autor (2002, p. 285) acrescenta que o direito reflexivo "converte a política em mero instrumento de controle, administração e neutralização do entrechoque de opiniões e valores. E, por fim, priva de sentido o controle democrático do processo legislativo".

${ }^{148}$ Cf. Fiori (1997, p. $87-88 ; 142$ ). 
Nesse sentido, Lewandowski (2004, P. 93) ressalta que a globalização "acarretou uma distribuição de custos e benefícios marcadamente assimétrica, acentuando a diferença entre países ricos e pobres no tocante a renda, consumo e poder ${ }^{149}$. Em outras palavras, enriqueceu os que já são ricos, empobrecendo ainda mais os pobres"150.

De forma semelhante, Ianni (1989, p. 187) afirma o seguinte:

Quando o capital financeiro, aglutinando principalmente o industrial e o bancário, adquire a importância que já alcançou na economia brasileira, torna-se inevitável o agravamento das desigualdades regionais ou desníveis setoriais. É que no mercado nacional, apoiado em grau crescente nas técnicas específicas de operação do capital financeiro, facilita a drenagem de recursos de um setor para outro, de uma zona para outra, sempre no sentido de acelerar a acumulação.

A globalização econômica também apresenta significativos impactos ambientais negativos decorrentes dos hábitos de consumo e do grande aumento da produção de bens materiais. Além disso, devido às maiores restrições ambientais estabelecidas por muitos países desenvolvidos, diversas indústrias transferem a parte mais poluente de sua produção para países subdesenvolvidos nos quais as regras ambientais são menos exigentes (LEWANDOWSKI, 2004, p. 98 - 100).

Ocorre também uma transmissão global da produção dos meios de comunicação de massa e da indústria cultural, a qual é controlada por grandes conglomerados econômicos, e apresentam grande padronização, o que representa "uma ameaça à diversidade cultural e ao pluralismo de opiniões e crenças, cuja preservação constitui

\footnotetext{
${ }^{149}$ Em seguida o autor (2004, p. 95) acrescenta: A pobreza, em verdade, aumentou no planeta desde o término da Segunda Guerra Mundial. E, apesar da aceleração que sofreu o processo de integração econômica desde o fim da Guerra Fria, especialmente a partir da década de 90, grande parte das pessoas na América Latina, no Oriente Médio e na Ásia Central ficou mais pobre. Já a expectativa de vida e os rendimentos dos africanos não registraram qualquer incremento desde então. Na verdade, a globalização econômica vem aumentando a miséria no mundo. Santos $(2002$, p. 30) salienta que "a globalização neoliberal corresponde a um novo regime de acumulação do capital, um regime mais intensamente globalizado que os anteriores, que visa, por um lado, dessocializar o capital, libertando-o dos vínculos sociais e políticos que no passado garantiram alguma distribuição social e, por outro lado, submeter a sociedade no seu todo à lei do valor, no pressuposto de que toda atividade social é mais bem organizada quando organizada sob a forma de mercado. A consequiência principal desta dupla transformação é a distribuição extremamente desigual dos custos e das oportunidades produzidas pela globalização neoliberal no interior do sistema mundial, residindo aí a razão do aumento exponencial das desigualdades sociais entre países ricos e países pobres e entre ricos e pobres no interior do mesmo país".

${ }^{150}$ Martin e Schumann (1997, p. 319) asseveram que "do ponto de vista econômico, a integração dos mercados é altamente eficaz. Mas, na distribuição da riqueza assim gerada, a máquina econômica global, livre de controles estatais, não funciona nada bem e o número de perdedores excede de longe o de vencedores".
} 
condição de sobrevivência da própria democracia""151 (LEWANDOWSKI, 2004, p. 106 108).

Além disso, assinala-se que até a década de sessenta do século XX, era possível supor a existência de "coletividades e organizações de classe dos trabalhadores caracteristicamente grandes, conscientes e bem organizadas", as quais se valiam do voto como instrumento de reforma social e implantação das políticas sociais do Estado de bemestar social. Porém, a partir de meados da década de setenta, observa-se uma "rápida decomposição ou desestruturação das coletividades", de maneira que a sociedade se revela muito mais plural e diversificada, e os conflitos também não se processam como conflitos de classe, mas sim como conflitos entre uma "pluralidade de grupos e categorias relativamente pequenos, que mudam rapidamente de tamanho, influência e coerência interna, sem um eixo dominante de conflito amplamente reconhecido". Assim, a perda de apoio político do Estado de bem-estar não pode ser explicada somente pelas crises fiscais e econômicas, nem pela ascensão de elites neoconservadoras, mas também pelo referido processo de desintegração social que fortalece o individualismo e enfraquece os vínculos de solidariedade, processo no qual o que cada um busca é "aproveitar-se" do Estado de bem-estar (OFFE, 1995, p. 306 - 308).

Em contraposição à globalização neoliberal hegemônica, começa a surgir uma "globalização alternativa, organizada da base para o topo das sociedades", de caráter emancipatório, a qual é

constituída pelas redes e alianças transfronteiriças entre movimentos, lutas e organizações locais ou nacionais que nos diferentes cantos do globo se mobilizam para lutar contra a exclusão social, a precarização do trabalho, o declínio das políticas públicas, a destruição do meio ambiente e da biodiversidade, o desemprego, as violações dos direitos humanos, as pandemias, os ódios interétnicos produzidos direta ou indiretamente pela globalização neoliberal (SANTOS, 2002, p. 13).

\footnotetext{
151 Observa-se, ainda, que a "publicidade comercial transmitida pela mídia eletrônica levou a uma uniformização dos hábitos de consumo que acabou moldando o próprio modo de vida das pessoas" (LEWANDOWSKI, 2004, p. 105). Isso porque, explica o autor (2004, p. 105), "as empresas que atuam no mercado globalizado agem no sentido de homogeneizar a demanda, para forçar o consumo de produtos e serviços padronizados", objetivando os ganhos decorrentes do aumento da escala de produção. Além disso, conclui o autor (2004, p. 105 - 106): "ao contrário do que ensina a teoria econômica clássica, a oferta de bens num mundo globalizado não é condicionada pela sua procura por parte dos consumidores, mas é determinada pelos interesses das grandes corporações e dos investidores internacionais". E completa (2004, p. 106): "as empresas multinacionais, portanto, não adaptam os seus produtos e serviços aos gostos dos consumidores. Ao contrário, impõem-lhes padrões tecnológicos e estéticos que melhor atendam aos seus próprios objetivos comerciais, motivo pelo qual podem ser encontrados, em todo o mundo, os mesmos automóveis, televisores, refrigeradores, computadores etc".
} 
Esta alternativa exige, por um lado, não obstante as dificuldades existentes, que o Estado regule o mercado $^{152}$ (SANTOS, 2001, p. 94 - 95) e, por outro, a cooperação internacional, em torno da qual já existem alguns sinais positivos (MARTIN e SCHUMANN, 1997, p. 294 - 295).

Martin e Schumann (1997, p. 320) assinalam que "dentro de uma solitária caminhada nacional, não há escapatória para a armadilha do mercado global”. Por isso, exige-se uma cooperação global, não no sentido de se retornar aos tempos em que não havia a integração comercial à qual se assiste hoje, mas para direcioná-la para "caminhos social e democraticamente compatíveis, transformando a globalização da injustiça num processo de mútuas compensações por todo o planeta".

Faz-se necessário, também, "reinventar a política" e a "ressignificação da democracia e da cidadania". Porém, em um mundo no qual muitos centros de poder concorrem com o Estado, esta tarefa não pode ser desempenhada com base nos "esquemas cognitivos com que aprendemos a interpretar a política", tais como as dicotomias Estado e sociedade, público e privado e nacional e internacional (FARIA, 2003, p. 14).

Resumidamente, em sentido amplo, a globalização é um fenômeno que acompanha a humanidade ao longo de toda sua história. Porém, em sentido estrito, trata-se de um processo de integração sistêmica da economia no âmbito mundial, iniciado nos anos setenta e oitenta do século XX, sob o impulso dos avanços tecnológicos, especialmente no campo da informática, da uniformização do padrão monetário e do avanço das políticas neoliberais, principalmente a liberalização do fluxo de mercadorias e capitais. A globalização não se viabilizou independentemente do Estado, mas como fruto de uma política para ela voltada. Como consequências fundamentais, a globalização capitalista apresenta: uma drástica redução da capacidade de intervenção do Estado em matéria econômica, concentração de poder econômico e renda, destruição ambiental e coloca em questão o próprio sentido e o alcance da democracia representativa. Trata-se, ainda, de um contexto histórico em que os conflitos se manifestam de maneira plural e diversificada, não se processando como conflitos de classe, e no qual se enfraquecem os vínculos de solidariedade e se fortalece o individualismo.

\footnotetext{
${ }^{152}$ Sobre esse assunto, Martin e Schumann (1997, p. 293) afirmam que em todos os níveis manifesta-se um erro sistêmico da integração global: enquanto o fluxo de mercadorias e capitais tornou-se disponível em escala mundial, a regulamentação e o controle continuaram sendo uma atribuição nacional". Assim, "a economia devora a política". Entretanto, "o Estado e seu governo continuam sendo a única instância junto à qual os cidadãos e eleitores podem reivindicar justiça e reformas".
} 
O contexto da globalização impõe, como se discutiu, drásticos limites para a atuação do Parlamento no controle democrático do poder político com o objetivo de promover a concretização dos direitos econômicos e sociais, basicamente, porque sua atuação é restrita aos limites territoriais, enquanto as decisões econômicas são tomadas no âmbito global. São, na verdade, limites não somente do Parlamento, mas do Estado Nacional como um todo. Ressalta-se que esse fato não é uma consequência inevitável do progresso científico e tecnológico, mas fruto de decisões políticas orientadas pela ideologia neoliberal. Todavia, tomadas essas decisões em diferentes partes do mundo, não há como voltar atrás, muito menos por meio de ações isoladas do Estado.

Assim, o Estado e, portanto, o Parlamento, têm um papel importante a cumprir na regulação econômica e no combate aos efeitos perversos da globalização capitalista. Porém, essa atuação encontra limites que não podem ser superados por quaisquer reformas institucionais ou mudanças políticas internas, dependendo de decisões no plano internacional. Nesse sentido, as possibilidades que se abram, não são para o Parlamento, mas para a cooperação global, não por um regresso ao passado, não por menos globalização, mas sim por mais globalização: por uma globalização que não se limite à livre circulação de capitais e mercadorias, mas que abranja a equalização das condições de vida em patamares dignos para toda a humanidade. Isso, todavia, dependerá da atuação das organizações internacionais, governamentais ou não-governamentais.

Diante disso, a discussão que será feita no próximo capítulo sobre os limites e as possibilidades de atuação do Parlamento no controle democrático do poder político fica restrita a aspectos internos da instituição em estudo e ao seu relacionamento com os outros poderes do Estado, pois os limites dados pela globalização econômica não podem ser transpostos por meio de reformas institucionais no âmbito nacional.

\subsection{Conclusões do Capítulo.}

As discussões realizadas ao longo deste Capítulo podem ser sintetizadas nas seguintes conclusões:

1. O poder político consiste na capacidade de o Estado, por meio de normas jurídicas e da força submetida ao direito, cumprir seu fim que é a realização do bem comum de um povo situado em um determinado território. Essa capacidade, dialeticamente, é determinada e participa da determinação da base econômica; enfrenta tendências inatas ao abuso e ao fato de estar a serviço do poder econômico, às quais deve se contrapor o controle democrático; e precisa, constantemente, se legitimar para se 
manter, o que depende do atendimento simultâneo de requisitos formais e materiais, tarefa diante da qual se apresentam grandes dificuldades.

2. Controlar, democraticamente, o poder político, não significa a simples contenção do poder a fim de evitar abusos, característica do Estado Liberal que serviu aos interesses de manutenção do sistema capitalista, sem nenhuma preocupação com a democracia material, também não se refere à crença utópica de um governo direto em uma sociedade com o grau de complexidade da contemporânea. Trata-se do controle dos atos dos governantes dentro de um sistema representativo, porém no sentido forte de direcionamento do poder, de estabelecimento de metas e diretrizes mediante planos, orçamentos e políticas públicas, bem como da responsabilização daqueles a quem compete a sua execução, com o objetivo perseguido pelo Estado Democrático de Direito de implantar, plenamente, os direitos humanos e fazer justiça material.

3. As funções do Parlamento são essencialmente duas: a legislativa e a de controle. Entende-se, em primeiro lugar, que sua atuação administrativa não constitui uma função, mas somente um meio para exercê-las. Da mesma maneira, representação e legitimação não são funções do Parlamento, mas, respectivamente, o fundamento e a consequência de seu exercício. Ou seja, o Parlamento legisla e controla o poder político porque representa o povo, e pelo exercício dessas funções, legitima, democraticamente, tal poder. Quanto à função legislativa, compreende-se que ela abrange a elaboração de emendas à Constituição (pois também são normas produzidas pelo Parlamento, sendo apenas de espécie diferente). Por fim, entende-se que a função de controle abrange a orientação política do Estado (mediante a definição de objetivos e diretrizes, bem como a escolha de membros de outros órgãos), a formação de lideranças políticas e a responsabilização dos executores das políticas (o que inclui fiscalização, investigação e julgamento político de autoridades). Aliás, a própria função legislativa, de certa forma, pode ser compreendida como uma manifestação do controle do poder político exercido pelo Parlamento.

4. Não se pode compreender, dentro da perspectiva de um Estado Democrático de Direito, o controle político exercido pelo Parlamento simplesmente como contenção do poder pelo poder. Muito menos se pode reduzir tão importante papel institucional à apuração de irregularidades e punição de atos de corrupção. O papel do Parlamento, submetido ao controle popular, tal como definido no primeiro item deste capítulo, é direcionar as ações do Estado para a concretização dos direitos humanos sociais e econômicos. Para tanto, estabelecendo um permanente canal de comunicação com o povo, 
o Parlamento deve estabelecer a orientação política do Governo, mesmo dentro do sistema Presidencialista, mediante a edição de normas que fixem diretrizes e metas essenciais a serem atingidas, inclusive em matéria de política econômica, a partir dos direitos e das linhas gerais previstos na Constituição. Depois disso, compete-lhe a fiscalização do cumprimento de suas orientações, tornando transparentes as ações do Executivo e submetendo-as ao debate público, de maneira que se constitua um verdadeiro espaço público para a definição democrática dos rumos do Estado. $\mathrm{Na}$ hipótese de não cumprimento de suas diretrizes e de não se atingirem, injustificadamente, as metas, o Parlamento deve dispor de mecanismos para aplicação de sanções e de outras medidas corretivas. Salienta-se que, em termos de políticas sociais, o Parlamento dispõe (e faz uso) de uma ampla competência legislativa. Todavia, a concretização desses direitos depende de dois fatores: a política econômica e a definição e aplicação do orçamento público. Quanto ao primeiro, o Parlamento se encontra quase que totalmente excluído. No que se refere ao orçamento público, trata-se do principal mecanismo de direcionamento das ações do governo de que o Parlamento dispõe, todavia, ele também sofre grandes limitações. Assim, os instrumentos de controle relacionados à fiscalização dos atos do Executivo pelo Parlamento constituem um mecanismo complementar à sua primeira forma de atuação que é a fixação das metas e diretrizes. Desta maneira, sem a definição da orientação política do Estado pelo Parlamento, sua atuação fiscalizadora perde grande parte de seu valor. Por outro lado, de nada adianta a clara definição das metas e diretrizes sem uma eficiente fiscalização e sem os mecanismos de correção e de sanção no caso de seu descumprimento. Em termos estruturais, a viabilização dessas funções depende, sobretudo, do fortalecimento das Comissões Permanentes.

5. Em sentido amplo, a globalização é um fenômeno que acompanha a humanidade ao longo de toda sua história. Porém, em sentido estrito, trata-se de um processo de integração sistêmica da economia no âmbito mundial, iniciado nos anos setenta e oitenta do século XX sob o impulso dos avanços tecnológicos, especialmente no campo da informática, da uniformização do padrão monetário e do avanço das políticas neoliberais, principalmente a liberalização do fluxo de mercadorias e capitais. A globalização não se viabilizou independentemente do Estado, mas como fruto de uma política para ela voltada. Como consequências fundamentais, a globalização capitalista apresenta: uma drástica redução da capacidade de intervenção do Estado em matéria econômica; concentração de poder econômico e renda; destruição ambiental; e coloca em questão o próprio sentido e o alcance da democracia representativa. Trata-se, ainda, de um 
contexto histórico em que os conflitos se manifestam de maneira plural e diversificada, não se processando como conflitos de classe, e no qual se enfraquecem os vínculos de solidariedade e se fortalece o individualismo.

6. O contexto da globalização impõe drásticos limites para a atuação do Parlamento no controle democrático do poder político com o objetivo de promover a concretização dos direitos econômicos e sociais, basicamente, porque sua atuação é restrita aos limites territoriais, enquanto as decisões econômicas são tomadas no âmbito global. São, na verdade, limites não somente do Parlamento, mas do Estado Nacional como um todo. Ressalta-se que esse fato não é uma consequência inevitável do progresso científico e tecnológico, mas fruto de decisões políticas orientadas pela ideologia neoliberal. Todavia, tomadas essas decisões em diferentes partes do mundo, não há como voltar atrás, muito menos por meio de ações isoladas do Estado. Assim, o Estado, como também o Parlamento têm um papel importante a cumprir na regulação econômica e no combate aos efeitos perversos da globalização capitalista. Porém, essa atuação encontra limites que não podem ser superados por quaisquer reformas institucionais ou mudanças políticas internas, dependendo de decisões no plano internacional. Nesse sentido, as possibilidades que se abrem, não são para o Parlamento, mas para a cooperação global, não por um regresso ao passado, não por menos globalização, mas sim por mais globalização: por uma globalização que não se limite à livre circulação de capitais e mercadorias, mas que abranja a equalização das condições de vida em patamares dignos para toda a humanidade. Isso, todavia, dependerá da atuação das organizações internacionais, governamentais ou nãogovernamentais.

Partindo-se desses pressupostos que delimitam o campo temático desta pesquisa, no próximo capítulo, discorrer-se-á sobre os limites e as possibilidades da atuação do Parlamento no controle democrático do poder político, no contexto da globalização capitalista, e com o objetivo de cumprir sua missão institucional na concretização dos direitos humanos econômicos e sociais.

\section{CAPÍTULO 2 - LIMITES E POSSIBILIDADES DA ATUAÇÃO DO PARLAMENTO NO CONTROLE DEMOCRÁTICO DO PODER POLÍTICO.}


A propósito da questão central desta pesquisa, foram levantadas três hipóteses de resposta na Introdução: (1) o Parlamento não é capaz de realizar a contento o controle democrático do poder político, pois seu papel institucional foi esvaziado, de maneira que a concretização dos direitos humanos econômicos e sociais compete aos Poderes Executivo e Judiciário, ou ao mercado e às instituições da sociedade civil; (2) o Parlamento pode realizar plenamente tal tarefa, ocupando ainda o centro da vida política, tal como na época de suas origens, porém, agora, a partir da compreensão da idéia de controle como direcionamento e não como contenção; (3) o Parlamento tem um papel fundamental no controle do poder político para a concretização dos direitos econômicos e sociais, porém sua atuação tem limites e apresenta vários pontos de estrangulamento, de maneira que é preciso definir com clareza as possibilidades de sua atuação a fim de que sejam, adequadamente, desenvolvidas, por meio da revisão de seu desenho institucional.

No presente Capítulo, demonstrar-se-á que a terceira hipótese é a correta.

Para tanto, inicialmente, serão feitas algumas considerações gerais sobre a separação de poderes, pois se trata do fundamento teórico-institucional no qual se processa a atuação do Parlamento. Em seguida, será analisada cada uma das limitações que se apresentam: (1) a própria dinâmica de funcionamento e de controle do poder dentro do Parlamento; (2) a transferência de poder normativo do Legislativo para o Executivo; (3) a tecnificação e a falsa despolitização das decisões políticas; (4) o controle político do Executivo sobre o Parlamento (5) a definição do orçamento público; e (6) a judicialização da política e politização da justiça.

\subsection{Considerações Gerais sobre a Separação de Poderes.}

A separação de poderes pode ser vertical (territorial) ou horizontal (funcional). No primeiro caso, o Estado se divide em diferentes unidades, com variados graus de autonomia, tendo a forma federal o maior deles. No segundo tipo, há uma "diferenciação funcional" do poder do Estado em diferentes órgãos que estabelecem uma relação de controle mútuo (CANOTILHO, 1993, p. 687). Neste trabalho, cuida-se da última espécie, tradicionalmente denominada de "separação de poderes".

A raiz histórica da teoria da separação de poderes se encontra na teoria da constituição mista (combinação na direção do Estado dos poderes do rei, da aristocracia e da burguesia). Entretanto, a distinção entre as funções estatais e sua atribuição a órgãos diferentes, a fim de proteger a liberdade individual, tem sua origem na Inglaterra do século 
XVII, durante a luta contra o absolutismo. Só então a exigência da separação de poderes se concretizou de forma definitiva na Constituição inglesa (PIÇARRA, 1989, p. 17 - 18; 44 $45)$.

A sistematização da teoria ocorreu no século seguinte, dentro do contexto do nascimento do Estado Liberal ${ }^{153}$, quando predominava uma concepção negativa do Estado. Inicialmente, apresentava o objetivo exclusivo de proteção das liberdades individuais e da economia de mercado mediante a limitação do poder do Estado pelo próprio poder. Posteriormente, passou também atender ao propósito de melhorar sua eficiência. ${ }^{154}$

A separação de poderes, ao impedir a atuação "pronta e eficiente" do Estado ${ }^{155}$, também servia ao interesse da burguesia em se proteger de seu novo inimigo (a nascente classe dos assalariados), que poderia fazer de um Estado ativo um instrumento para melhoria de suas condições de vida em detrimento dos interesses da classe dominante. Nessa perspectiva, separação de poderes seria "um sistema concebido menos para impedir as usurpações do Executivo do que para obstar as reivindicações das massas populares" (LEAL, 1997, p. 27 - 31).

$\mathrm{O}$ antecedente teórico mais remoto dessa teoria se encontra em Aristóteles, que considerava injusta e perigosa a atribuição de poderes exclusivamente a um indivíduo. Porém, não se pode dizer que aí está sua origem, pois a preocupação do autor se resumia em diferenciar as formas de atividades dos órgãos, não abrangendo o estabelecimento de uma repartição de funções, nem a questão de seu exercício por órgãos distintos ${ }^{156}$. Maquiavel, em "O Príncipe”, apontou que, no começo do século XVI, já existiam três poderes distintos na França. Locke, no século XVII, foi o primeiro a afirmar a importância da separação de poderes, mas também não desenvolveu uma teoria completa. Foi Montesquieu, na obra "O Espírito das Leis", de 1748, quem desenvolveu a fórmula moderna da teoria da separação de poderes, baseada na experiência histórica da Inglaterra. Sua teoria, utilizada pela maioria das constituições contemporâneas, foi associada ao

${ }^{153}$ Cf. LEAL (1997, p. 19 - 22) e SALDANHA (1987, p. 83 - 86).

${ }^{154}$ Cf. BOBBIO, 2000, p. 128 - 131, CLÈVE, 1993, p. 31 - 33, DALLARI, 2001, p. 215 e LOEWENSTEIN, 1986, p. 232. De acordo com Saldanha (1981, p.27), a separação de poderes é um problema eminentemente liberal, visto que "seria um corretivo ao poder absoluto, e portanto ao tipo de estado que o liberalismo combateu e que precisou ser combatido para que se chegasse ao constitucionalismo e ao Estado-de-Direito" (SALDANHA, 1981, p. 27).

${ }^{155}$ Saldanha (1981, p. 29) afirma que a estruturação liberal dos poderes do Estado objetiva manter "a ação governamental dentro do mínimo necessário, impedindo-a de asfixiar as liberdades".

${ }^{156}$ Nesse sentido, Saldanha (1987, p. 91) salienta que "a questão dos poderes, tal como seria concebida e debatida no Ocidente contemporâneo, não foi propiciada pelo ordenamento político da polis", nem pelo pensamento de Aristóteles. 
Estado Democrático e deu origem à construção doutrinária conhecida como "sistema de freios e contrapesos". 157

Locke $^{158}$ (2003, p. 106) afirmava que

poderia ser tentação excessiva para a fraqueza humana a possibilidade de tomar conta do poder, de modo que os mesmos que têm a missão de elaborar as leis tenham nas mãos o poder de executá-las, isentando-se de obediência às leis que fazem, e com a possibilidade de amoldar a lei, não só na sua elaboração como na sua execução, a favor de si mesmos, tornando-se uma classe de interesse distinto dos demais, divergente da finalidade da sociedade e do governo; nas comunidades bem organizadas, nas quais o bem de todos é levado na devida conta, o poder legislativo é posto nas mãos de várias pessoas que, reunidas, têm o poder de elaborar as leis; feito isso e novamente separadas, ficam também sujeitas às leis que fizeram, o que representa uma obrigação nova e imediata para que as leis tenham em vista o bem geral.

Diante disso, o citado autor (2003, p. 106 - 108) propôs a separação entre os Poderes Legislativo (responsável pela edição das leis) e Executivo (responsável pela execução das leis), indicando, ainda, a existência do Poder Federativo (ao qual caberia cuidar das relações com outros Estados), que, embora seja distinto do Executivo, deveria ficar nas mãos do mesmo órgão ou da mesma pessoa.

Montesquieu (2001, p. 173) afirma que "há, em cada Estado, três espécies de poderes: o poder legislativo, o poder executivo das coisas que dependem dos direitos das gentes, e o poder executivo das que dependem do direito civil"159.

Em seguida, o autor (2001, p. 173) adverte:

quando se reúne na mesma pessoa, ou no mesmo corpo de magistratura, o poder legislativo e o poder executivo, não existe liberdade; porque pode-se temer que o

${ }^{157}$ Cf. DALLARI, 2001, p. 216 - 219, LOEWENSTEIN, 1986, p. 54 - 55 e MALBERG, 1948, p. 741 - 743.

158 A doutrina de Locke (2003, p. $24-35 ; 70-72 ; 92$ - 105) tem como fundamento a igualdade entre todos os homens. Ele também afirma o valor da liberdade do homem sob o governo (liberdade civil), a qual consiste na existência de regras permanentes, comuns a todos e criadas pelo poder legislativo estabelecido pela própria sociedade e por ela autorizado para estabelecer as normas. A sociedade surge quando os homens se associam mediante seu livre consentimento, com o objetivo de preservar a propriedade, constituindo um "corpo político sob um governo supremo". Como o "desfrute da propriedade em paz e segurança" é assegurado por meio das leis, o autor considera o Legislativo eleito pela comunidade como o "o poder supremo da comunidade", de maneira que nenhuma norma é válida sem sua sanção. Embora tenha essa proeminência, o Legislativo é limitado pelo "bem geral da sociedade" e pelo direito de propriedade. Além disso, não tem o direito de "governar por meio de decretos extemporâneos e arbitrários", e não pode "transferir o poder recebido de elaborar leis a quem quer que seja".

${ }^{159} \mathrm{O}$ autor (2001, p. 174) assim define cada uma das funções: "Pelo primeiro, o príncipe, ou o magistrado, elabora leis para um certo tempo ou para sempre, e corrige ou revoga as existentes. Pelo segundo, faz a paz ou a guerra, envia ou recebe embaixadas, instaura a segurança, impede invasões. Pelo terceiro, pune os crimes, ou julga as pendências entre particulares. Chamaremos a este último o poder de julgar e ao outro simplesmente o poder executivo do Estado". Ele (2001, p. 178) defende ser mais conveniente que o poder executivo esteja concentrado nas mãos de um só, devido à exigência de ações rápidas, enquanto que o legislativo deve estar nas mãos de muitos. 
próprio monarca, ou o próprio senado, faça leis tirânicas para executá-las tiranicamente. Também não existe liberdade, se o poder de julgar não estiver separado do poder legislativo e do poder executivo. Se estivesse ligado ao poder legislativo, o poder sobre a vida e a liberdade dos cidadãos seria arbitrário: pois o juiz seria o legislador. Se estivesse unida ao poder executivo, o juiz poderia ter a força de um opressor. Tudo estaria perdido se o mesmo homem, ou o mesmo corpo de principais, ou de nobres, ou do povo, exercesse esses três poderes: o de fazer leis, o de executar as resoluções públicas, e o de julgar os crimes ou as pendências entre os particulares ${ }^{160}$.

Montesquieu (2001, p. 181) pondera que "esses três poderes deveriam formar um repouso ou uma inação. Como, porém, pelo movimento necessário das coisas, são obrigados a caminhar, serão forçados a caminhar de comum acordo".

Como se pode observar claramente, a teoria não afirma existirem poderes distintos no Estado, pois o poder de dominação estatal é único, mas sim órgãos diferentes que expressam esse poder e, entre os quais, estão distribuídas diferentes competências. ${ }^{161}$ Trata-se, portanto, mais precisamente, de uma teoria de separação de funções ${ }^{162}$ (MALBERG, 1948, p. $744-747,759,761$ - 763, 766).

O objetivo de Montesquieu, em sua obra, era "recomendar a divisão do poder como remédio contra o absolutismo e como garantia da liberdade" 163 (FERREIRA FILHO, 1968, p. 51) mediante a "contenção do poder pelo próprio poder"164 (BASTOS, 1988, p. 433).

Nesse sentido, Madson (2001, p. 273 - 274) já afirmava a necessidade de se atribuir "meios constitucionais e motivações pessoais" para os que administram cada ramo

\footnotetext{
${ }^{160}$ Madson (1979, p. 1240, Afirma que “a acumulação dos poderes Legislativo, Executivo e Judiciário nas mãos de um só indivíduo, ou de uma só corporação, seja por efeito de conquista ou eleição, constitui tirania". Ver também: Piçarra (1989, p. 52). Inclusive, em sua primeira versão, a doutrina foi aplicada "como arma ideológica de luta contra os abusos e arbitrariedades do Longo Parlamento" na Inglaterra, retirando-lhe as competências jurisdicionais que deveriam caber a outros órgãos constitucionais (PIÇARRA, 1989, p. 49).

${ }^{161}$ Cf. CLÈVE, 1993, p. 27.

162 Nesse sentido, Kelsen (2001, p. 365) assinala que a expressão três poderes do Estado se refere às suas funções, as quais na verdade são duas, a legislativa e a executiva, pois tanto o Poder Executivo como o Judiciário executam as normas gerais, diferenciando-se somente pela maneira como se dá esse processo de execução.

${ }^{163}$ Cf. LEAL (1997, p. 24). Segundo Kelsen (2001, p. 402), o significado histórico fundamental do princípio da separação de poderes é atuar contra a concentração de poderes (KELSEN, 2001, p. 402).

${ }^{164}$ Ferreira Filho $(1986$, p. 91; 94) explica a teoria da separação de poderes de Montesquieu da seguinte maneira: "o poder do Estado, para que não se torne abusivo, tem de ser dividido e distribuído de tal sorte que a independência recíproca e especialização numa das funções básicas dos que contam com frações da soberania, impeça que qualquer um possa oprimir a quem quer que seja. O poder, portanto, se divide em podêres que são, em última análise, órgãos independentes e relativamente especializados do Estado". Essa divisão corresponderia a um ideal de busca de estabilidade política, mediante um desenho institucional que possibilitasse um equilíbrio entre as três forças sociais da época de Montesquieu (monarca, nobreza e povo), as quais deveriam ter possibilidade de participação no governo.
} 
do governo resistirem a interferências dos outros, de maneira que "a ambição deve ser utilizada para neutralizar a ambição" em um sistema de "freios e contrapesos". Porém, diante da impossibilidade de atribuir "a cada um dos ramos do governo uma capacidade igual de autodefesa", no "governo republicano predomina necessariamente a autoridade legislativa" ${ }^{\prime 65}$.

A positivação do princípio da separação de poderes ocorre, primeiramente, nas Constituições das ex-colônias inglesas da América, concretizando-se, em definitivo, na Constituição dos Estados Unidos de $1787^{166}$, e tornando-se dogma constitucional com a Revolução Francesa (SILVA, 2001, p. 113).

Diante do exposto até aqui, as características do princípio da separação ${ }^{167}$ de poderes podem ser resumidas nas seguintes: as funções estatais são distribuídas entre diferentes titulares que conservam interdependências e dependências entre si, objetivando o controle mútuo e a coibição de abusos; os diferentes órgãos separados, embora não exerçam cada função exclusivamente, devem exercer aquela que lhe é específica de forma preponderante; a separação também deve ocorrer no plano pessoal, ou seja, uma mesma pessoa não pode ter sob seu poder diferentes órgãos de soberania ${ }^{168}$; opera-se um sistema de freios e balanços recíprocos entre os órgãos, exigindo-se, para muitos atos, a aprovação ou manifestação de mais de um deles ${ }^{169}$; e, por fim, o princípio deve ser compreendido sob

\footnotetext{
${ }^{165}$ Ferreira Filho (1968, p. 97) afirma que na teoria clássica da separação de poderes há uma supremacia do Legislativo em virtude da função que desempenha, pois faz as leis a serem aplicadas pelos outros. Porém, tanto na obra de Locke como na de Montesquieu, não há relação de subordinação entre os poderes. Cf. SALDANHA (1987, p. 87).

${ }^{166}$ A interpretação americana da separação dos poderes não se revela uma teoria abstrata, mas, ao contrário, reduz-se a "fórmulas práticas de equilíbrio dos órgãos supremos do Estado com o objectivo concreto de impedir a concentração e o exercício despótico do poder". Trata-se do sistema de "freios e contrapesos checks and balances". Ou seja, "em vez de confiarem cada função a seu órgão especializado, os autores da Constituição americana fraccionaram as funções, e estabeleceram a colaboração forçada de vários órgãos no exercício de cada uma" (CAETANO, 1963, p. 157). Grau (2008, p. 226) pondera que, enquanto para Montesquieu a separação de poderes é "um mecanismo voltado imediatamente à promoção da liberdade do indivíduo", para os federalistas norte-americanos, trata-se de um meio para a "otimização do desempenho das funções do Estado".
}

168 Órgãos de soberania são aqueles: (1) cujo status e competência são imediata e fundamentalmente “constituídos" pela constituição; (2) que dispõe de um poder de auto-organização interna; (3) que não estão subordinados a quaisquer outros; (4) que estabelecem relações de interdependência e de controlo em relação a outros órgãos igualmente ordenados na e pela constituição (CANOTILHO, 1993, p. 696).

${ }^{169}$ Piçarra (1989, p. 13) explica que o princípio da separação de poderes "pressupõe uma distinção material das funções estaduais, devendo o desempenho de cada uma delas caber a um órgão ou grupo de órgãos específico, independentemente dos demais; que esta distinção material das funções estaduais e a separação orgânico-pessoal nela fundada se pautam não só por precauções de ordem jurídico-dogmática mas também, ou sobretudo, por preocupações garantísticas: pretende-se que nenhum desses órgãos chegue a controlar, por si só, a totalidade do poder do Estado; que a entrega de cada uma das fracções em que o poder político seja dividido a diversos órgãos há-de fazer com que cada um constitua perante o outro um freio e simultaneamente um contrapeso, prevenindo-se assim a concentração e o abuso do poder, a favor da liberdade individual. Ressalva-se, contudo, que, porque uma separação orgânico-funcional rígida não é viável 
uma perspectiva histórica, pois não se trata de "um dogma de valor intertemporal”, nem de um esquema constitucional rígido (CANOTILHO, 1993, p. 687 - 690).

Os denominados Poderes são independentes porque os membros de um não dependem da confiança ou da autorização dos de outro para sua investidura, para o exercício de suas funções e para a organização de seus respectivos serviços, respeitadas as disposições constitucionais e legais. Além disso, são harmônicos, porque deve haver cortesia no relacionamento entre seus membros, respeito às suas prerrogativas e interferências mútuas, já que nem a divisão de funções, nem a independência entre os poderes podem ser absolutas ${ }^{170}$ para que se opere o sistema de freios e contrapesos (SILVA, 2001, p. $114-115$ ).

Assim sendo, o princípio da separação de poderes apresenta dois fundamentos: a especialização funcional e a independência dos órgãos que exercem as funções. Portanto, não basta a simples especialização de tarefas de acordo com suas características; é preciso que cada uma delas seja atribuída a órgãos distintos ${ }^{171}$ (SILVA, 2001, p. 112 - 113).

Todavia, a distinção entre as funções exercidas pelos órgãos não é absoluta, pois, na realidade, muitos atos do Estado envolvem tanto a criação como a aplicação do direito e, em muitas ocasiões, um órgão cumpre ambas as funções em conjunto, ${ }^{172}$ o que em nada contradiz com a doutrina de Montesquieu ${ }^{173}$ (KELSEN, 2001, p. 366).

na prática, a independência entre os vários órgãos não pode ser absoluta, antes devendo existir entre eles mecanismos de coordenação e interdependência - o que, em última análise, reforçará a fiscalização e o controle recíprocos".

${ }^{170}$ Canotilho (1993, p. 953 - 955) assinala que a separação e interdependência entre os órgãos de soberania constituem um mecanismo de defesa da Constituição, por meio da responsabilização e controle mútuos.

${ }^{171}$ Provenza (2000, p. 34 - 36) define a separação de poderes como "um poder político estruturado de forma repartida de ordem a prevenir abusos bem como possibilitar uma organização funcional eficaz”. E afirma que seu fim essencial é a garantia da liberdade, por meio da "quebra do poder unipessoal e sua necessária inibição, contenção"

${ }^{172}$ Por exemplo, o Chefe do Poder Executivo também participa do processo legislativo por meio da iniciativa para projetos de lei e pelo veto. Da mesma maneira, o Judiciário tem uma participação por meio da formação de precedentes judiciais e do controle de constitucionalidade. Assim sendo, não há efetiva separação, mas distribuição de poderes em que um dos órgãos tem um papel preponderante nessa função (KELSEN, 2001, p. $388-390)$.

${ }^{173}$ Madson (1979, p. 124 - 126) destaca que nem mesmo na doutrina de Montesquieu a separação de poderes se apresentava de forma rígida. Primeiramente, porque foi inspirada na Constituição Inglesa, na qual os três poderes não são "inteiramente distintos e separados", de maneira que o quis dizer foi que, "quando dois poderes, em toda a sua plenitude, se acham concentrados numa só mão, todos os princípios de um governo livre ficam subvertidos". Ele ressalta, ainda, que nas Constituições dos Estados norte-americanos anteriores à formação da federação também não havia integral distinção e separação entre os poderes. Malberg (1948, p. 777 - 778) assinala que, em nenhum momento, "entro em el pensamiento de Montesquieu que los órganos legislativo y ejecutivo hubieran de quedar constituídos uno frente a outro, em uma postura de completa independência, que impiedisse toda relación entre ellos. Muy al contrario, la teoría de Montesquieu implica indudablemente la necessidade de estabelecer entre estas dos autoridads ciertas relaciones de dependência". Grau (2008, p. 229 - 230) afirma que Montesquieu não defende a "impenetrabilidade" entre os poderes, nem sua "efetiva separação, mas sim uma distinção entre eles, que, não obstante, devem atuar em clima de equilíbrio”. Cf. CUÉLLAR, 2001, p. 24 - 25 e ROCHA, 2004, p. 77 - 78. 
Como já assinalado, a separação de poderes foi concebida num momento histórico determinado ${ }^{174}$, em que o Estado apresentava atribuições mínimas e a grande preocupação era a limitação de seu poder ${ }^{175}$. Porém, nas primeiras décadas do século XX, o contexto socioeconômico passou a exigir um Estado mais forte e atuante (Estado de Bem-Estar Social), com novas atribuições. Nesse Estado intervencionista, passou a haver uma primazia do Poder Executivo, inclusive no campo da produção normativa, pois o Legislativo não estava preparado para atender a uma demanda legislativa mais numerosa e técnica, devido à carência de condições técnicas e à lentidão de seu processo decisório. Com isso, houve uma transformação do Estado legislativo em Estado administrativo, e substituiu-se a técnica da separação pela da limitação dos poderes ${ }^{176}$, a qual admite a preponderância de um dos órgãos de poder (dentro de determinados limites) ${ }^{177}$, sendo fundamental a idéia de controle e de físcalização entre eles, e não as competências a cada um atribuídas. ${ }^{178}$

Além disso, embora a separação entre Parlamento e Governo não tenha perdido sentido, o dualismo prevalecente é estabelecido entre maioria e oposição ${ }^{179}$, pois o mesmo partido ou grupo de partidos compõem o governo e constituem a maioria parlamentar de sustentação de um lado, e, de outro, há o partido ou grupo de partidos que não fazem parte do governo e integram o bloco parlamentar de oposição. Diante disso, coloca-se a questão de controle e equilíbrio de poderes entre esses dois polos, pois a condução das ações políticas fica a cargo fundamentalmente do bloco governista, e o controle é exercido

\footnotetext{
${ }^{174}$ Nesse sentido Loewenstein (1986, p. 56) afirma que el principio de la separación de las funciones estatales según sus diversos elementos substanciales y su distribuición entre diferentes detentadores, ni es esencial para el ejercicio del poder político, ni presenta uma verdad evidente y válida todo tiempo. El descubrimiento o invención de la teoria de la separación de instituiciones estuvo determinado por el tiempo e las circunstancias como respuesta ideológica del liberalismo político contra el absolutismo monárquico de la monarquía em el siglo XVII y XVII.

${ }^{175}$ Leal $(1997$, p. 17 - 19; 34) afirma que as instituições políticas possuem uma natureza instrumental, ou seja, existem para servirem à realização de um objetivo, o qual as condiciona. E isto ocorre com a divisão de poderes, como instituição política, apresenta uma natureza instrumental que só pode ser compreendida "dentro do quadro da revolução burguesa", sendo hoje uma "construção doutrinária superada".

${ }^{176}$ No Parlamentarismo, ocorre uma colaboração entre o Executivo e o Legislativo e no Presidencialismo uma independência orgânica e harmonia (SILVA, 2001, p. 113). Loewenstein ( 1986, p. 50) salienta que há menos independência e maior interdependência no caso do parlamentarismo, em que o governo está incorporado à assembléia.

${ }^{177}$ A esse respeito, Loewenstein (1986, p. 61) assevera que "la legislación y la ejecución de las leyes non son funciones separadas o separables, sino sensivelmente diferentes técnicas del liderazgo político. Y perntence a la biologia del proceso del poder que el liderazgo político este em manos del gobierno, um grupo reducido, eficaz e com la capacidad para la acción, em lugar de ser ejercido por uma asamblea com multiples miembros, lenta e incapaz frecuentemente de formar uma voluntad política unida".

${ }^{178}$ Cf. BAPTISTA, p. 17 - 18, CLÈVE, 1993, p. 20, DALLARI, 2001, p. 220 - 221, LOEWENSTEIN, 1986, p. 67, MALBERG, 1948, p. 854.

${ }_{179}$ Piçarra (1989, p. 243 - 245) não concorda com a tese de que o verdadeiro dualismo que ocorre no Estado contemporâneo não é entre Executivo e Legislativo, mas entre governo (maioria) e oposição (minoria), porque esta não constitui um órgão próprio e aquele domina o centro do poder estatal.
} 
primordialmente pela oposição. Para tanto, consagram-se os direitos à oposição democrática e os mecanismos necessários para efetivar a responsabilidade política do governo (CANOTILHO, 1993, p. 693 - 694).

Buscando-se preservar formalmente a separação de poderes, por se tratar de dogma ligado à idéia de democracia, e criar mecanismos que permitam aumentar a eficiência do Estado, recorre-se a institutos como a delegação de poderes e a transferências de competências do Legislativo para o Executivo nas próprias Constituições ${ }^{180}$. Com isso, o Parlamento conserva sua organização tradicional, mas sofre uma drástica redução em sua “participação na formação da vontade do Estado" (DALLARI, 2001, P. 220).

Porém, "tais soluções são artificiais, pois mantêm uma organização sem manterem o funcionamento que determinou sua criação", o que não resolve os problemas apresentados. Diante disso, "é necessário que se reconheça que o dogma da rígida separação formal está superado, reorganizando-se completamente o Estado, de modo a conciliar a necessidade de eficiência com os princípios democráticos" $" 181$ (DALLARI, 2001, p. 222).

Ademais, a teoria da separação de poderes nunca conseguiu assegurar a "liberdade dos indivíduos ou o caráter democrático do Estado", pois a liberdade era garantida somente para um pequeno grupo dentro da sociedade injusta criada pelo liberalismo. Além disso, em muitos regimes em que vigora formalmente a separação de poderes, existem Executivos antidemocráticos que, sem quebrar as regras constitucionais, comandam, informalmente, Legislativos sem representatividade que agem sob as determinações do outro Poder. Por outro lado, em muitos regimes parlamentaristas, aos quais não se aplica o princípio da separação de poderes, há mais respeito à liberdade e à democracia do que nos Estados em que há a separação (DALLARI, 2001, P. 220).

Analisando esses fatos, Loewenstein (1986, p. 62) propõe uma nova divisão tripartida: "la decisión política conformadora o fundamental (policy determination); la ejecución de la decisión (policy execution) y el control político (policy control)".

Decisões políticas fundamentais são aquelas decisivas e determinantes da conformação da comunidade, abrangendo aspectos políticos, econômicos, sociais e até

${ }^{180}$ Cf. MORAES FILHO (2003, p. $\left.166-176\right)$.

${ }^{181}$ Nesse sentido, Moraes (2005, p. 370) afirma que o "Direito Constitucional contemporâneo, apesar de permanecer na tradicional linha da idéia de Tripartição de Poderes, já entende que esta fórmula, se interpretada com rigidez, tornou-se inadequada para um Estado que assumiu a missão de assegurar a todo o seu povo o bem-estar, devendo, pois, separar as funções estatais, dentro de um mecanismo de controle recíprocos, denominado "freios e contrapesos" (checks and balances)". Piçarra (1989, p. 258) conclui que "no Estado de Direito do século XX a ideia de controlo, fiscalização e também coordenação recíprocos tornou-se o centro de gravidade do princípio da separação de poderes". 
morais. Mesmo neste contexto de aceleradas transformações sociais, as decisões efetivamente fundamentais são raras, porém é difícil distinguir entre o que é e o que não é fundamental, sendo um indício desse fato o interesse público em torno de uma determinada decisão. As decisões políticas fundamentais são influenciadas por detentores invisíveis do poder, mas sua formulação e realização cabem aos detentores legítimos do poder, mais especificamente ao Parlamento (LOEWENSTEIN, 1986, p. 63 - 64).

A execução das decisões políticas fundamentais pode ocorrer em qualquer campo da atividade estatal, inclusive no campo legislativo, no qual muitas normas emanadas são específicas e apresentam caráter técnico e utilitário, pois a legislação deixou de ser uma categoria independente e separada da execução. A administração envolve a execução das decisões políticas e a aplicação aos casos concretos das disposições técnicas e utilitárias emanadas por meio de leis, por meio de estruturas físicas e da burocracia governamental. A função jurisdicional também consiste na aplicação da decisão política fundamental ao caso concreto, de maneira que "no realiza uma función independiente em el processo de poder" (LOEWENSTEIN, 1986, p. 66 - 67).

Conclui-se que, embora o Estado tenha passado por muitas transformações, permanece a necessidade de controlar seu poder, não só para limitá-lo contra o arbítrio, mas também para direcioná-lo para a concretização dos direitos econômicos e sociais. Entretanto, os mecanismos a serem utilizados não podem ser formulados a partir dos modelos de Estado e de sociedade dos séculos XVIII e XIX ${ }^{182}$. Assim sendo, o princípio da separação de poderes rigidamente interpretado se encontra superado, porém a idéia de racionalização do poder que o inspirou continua viva. Portanto, o Executivo deve ser dotado dos meios necessários para atender às demandas sociais, mas, deve desempenhar essa tarefa orientado por diretrizes fixadas pelo Parlamento (por sua vez submetido ao controle popular), e os mecanismos necessários para seu controle devem ser aprimorados a fim de torná-los mais eficazes ${ }^{183}$.

\footnotetext{
${ }^{182}$ No mesmo sentido Dallari (2001, p. 130) pondera que para avançar na reestruturação das funções e órgãos estatais, é preciso que o homem do presente se desapegue das concepções do século XVII, "quanto à organização e aos objetivos do Estado Democrático", pois somente a partir desta postura se poderá pensar uma nova engenharia institucional que resolva os problemas de hoje.

${ }^{183}$ Nesse sentido, Clève $(1993$, p. 41 - 41) afirma que se "o princípio rígido e dogmaticamente interpretado da separação dos poderes não funciona, é preciso lembrar que ele, enquanto idéia racionalizadora do aparato estatal ou enquanto técnica de racionalização do poder para a garantia das liberdades, não pode ser esquecido, nem se encontra superado". De maneira semelhante, Piçarra (1989. p. 26) pondera que "na sua dimensão orgânico-funcional, o princípio da separação dos poderes deve continuar a ser encarado como princípio de moderação, racionalização e limitação do poder político-estadual no interesse da liberdade. Tal constitui seguramente o seu núcleo imutável. Deixou, no entanto, de pressupor necessariamente (ou, sobretudo, de se
} 
Salienta-se, por fim, que o atual contexto parece indicar que o sistema parlamentarista $^{184}$ de governo pode melhor contribuir para a atuação eficaz do Parlamento no controle do poder político, tal como compreendido nesta pesquisa, do que o presidencialista $^{185}$, por apresentar melhores possibilidades de responsabilização dos dirigentes do Poder Executivo e maior flexibilidade política ${ }^{186}$. Entretanto, as formas tradicionais de governo vêm sendo abandonadas diante da nova realidade social; portanto, “o presidencialismo e parlamentarismo já não são as opções necessárias para a formação de um governo" (DALLARI, 2001, p. 249 - 250)

\subsection{Limites para o Cumprimento da Missão Institucional do Parlamento decorrentes de sua Dinâmica de Funcionamento.}

Como se fixou no Capítulo anterior, o Parlamento tem por missão direcionar as ações do Estado para a concretização dos direitos humanos sociais e econômicos. Para tanto, precisa ser capaz de: estabelecer a orientação política do Governo, mediante a edição de normas que fixem diretrizes e metas essenciais a serem atingidas, inclusive em matéria

confundir com) uma classificação material das funções estaduais, aspirando a uma validade científica universal e intemporal".

${ }^{184}$ O Parlamentarismo apresenta três características básicas: distinção entre chefe de Governo e chefe de Estado, cabendo a este a função de representação e vínculo moral do Estado, e àquele o exercício do Poder Executivo após escolha pelo Parlamento, de maneira que muitos o consideram um delegado do Parlamento, e conseqüentemente, não há separação entre Legislativo e Executivo; chefia de Governo com responsabilidade política, pois o Primeiro Ministro e seu Gabinete podem ser demitidos caso percam a maioria parlamentar ou recebam voto de desconfiança, de maneira que seus mandatos têm prazo indeterminado; e a possibilidade de dissolução do Parlamento e convocação de novas eleições pelo chefe de Estado, mediante solicitação do chefe de Governo (DALLARI, 2001, p. 234 - 236). A favor do Parlamentarismo argumenta-se que "é mais racional e menos personalista, porque atribui responsabilidade política ao chefe do executivo e transfere ao Parlamento, onde estão representadas todas as grandes tendências do povo, a competência para fixar a política do Estado, ou, pelo menos, para decidir sobre a validade da política fixada". Contra esse sistema aponta-se sua fragilidade e instabilidade, as quais são incompatíveis com o que se exige do Estado contemporâneo (DALLARI, 2001, p. 237 - 238).

${ }^{185}$ No presidencialismo, adotado no Brasil, o Presidente da República exerce todo o Poder Executivo, acumulando as funções de Chefe de Estado, Chefe de Governo e Chefe da Administração Pública, cumprindo um mandato por tempo determinado, de maneira que não depende da confiança do Legislativo, e tem o poder de veto. Os membros do Legislativo são eleitos por período fixo e o órgão não está sujeito à dissolução, de maneira que a divisão de poderes é mais rígida, havendo maior independência e autonomia, embora devam ser harmônicos (SILVA, 2001, p. 508). A favor do Presidencialismo argumenta-se que as decisões são tomadas e postas em prática com rapidez, em virtude da unidade de comando e do fortalecimento do Executivo. Contrariamente, argumenta-se que esse regime, em que o Presidente é eleito por prazo certo e sem responsabilidade política, constitui "uma ditadura a prazo fixo", ressaltando-se que quando o Executivo é mais forte do que o Legislativo aquele obtém tudo o que quer deste e, quando se dá o inverso, o Executivo não consegue agir com eficácia, acarretando-se a ineficiência do Estado (DALLARI, 2001, p. 244 - 245).

${ }^{186}$ Uma discussão aprofundada sobre as características e as vantagens e desvantagens do Presidencialismo e do Parlamentarismo pode ser encontrada em Linz (1994). Esse autor entende que o Parlamentarismo é uma opção melhor, por permitir uma responsabilização mais eficaz do Chefe do Poder Executivo, evitar o personalismo e assegurar maior estabilidade política. Ver também Bastos (1988, p. 174 -175). Diferente é a posição de Abranches $(1988$, p. 32). O autor salienta que a "tradição político-institucional responde à específica dinâmica social do País", caracterizada pela heterogeneidade, diferenças e contradições sociais, as quais "contribuem para firmar esta combinação entre proporcionalidade e presidencialismo de coalizão", não havendo evidências convincentes de que o parlamentarismo, a representação majoritária ou o bipartidarismo poderiam garantir maior estabilidade institucional. 
de política econômica; fiscalizar o cumprimento de suas orientações, tornando transparentes as ações do Executivo e submetendo-as ao debate público; e, na hipótese de não cumprimento de suas diretrizes e ou de não se atingirem injustificadamente as metas, aplicar sanções e outras medidas corretivas.

Porém, na própria dinâmica de funcionamento do Parlamento já aparecem limites ao cumprimento desta missão institucional, os quais giram em torno de cinco questões básicas: ausência de domínio sobre informações e conhecimentos técnicos; dificuldade de formação de consensos; tempo do processo legislativo; centralização do processo decisório; característica patrimonialista do Estado brasileiro ${ }^{187}$.

O primeiro problema será analisado na quarta parte deste capítulo, quando se cuidará da tecnificação e da (falsa) despolitização da política, os demais serão discutidos a seguir.

A característica fundamental do funcionamento do Parlamento é a realização de discussões públicas ${ }^{188}$, as quais consistem no "intercâmbio de opiniões com o objetivo de convencer o opositor de algo verdadeiro ou correto, por meio de argumentos racionais", e não na simples negociação ou barganha. Para que a discussão se processasse adequadamente, pressuponha-se a existência de "predisposição para se deixar convencer", “desvinculação de ligações partidárias” e "isenção de interesses egoísticos". ${ }^{189}$

Tais pressupostos estavam presentes nos primeiros tempos do Parlamento, quando era o local da busca do consenso, pois todos os seus membros pertenciam à elite burguesa eleita pelo sufrágio censitário ${ }^{190}$. Todavia, esse Parlamento desempenhava somente os papeis de limitar o poder político, a fim de garantir a esfera privada de liberdade (sobretudo econômica) e de conservar o status quo.

Hoje, espera-se que o Parlamento exerça um papel transformador, direcionando a ação do Estado para a concretização dos direitos econômicos e sociais. Esse Parlamento,

\footnotetext{
${ }^{187}$ A propósito, Ferreira Filho (1968, p. 110 - 111) afirma que a reforma do Legislativo tem que enfrentar dois desafios: o domínio sobre a informação e os conhecimentos técnicos, e a aceleração do processo legislativo para se atender a velocidade de deliberação exigida pela época.

${ }^{188}$ Schmitt (1996, p. 33 - 34) afirma que a justificativa do Parlamento decorre da consideração de que o povo deveria tomar diretamente as decisões que afetam a coletividade. Porém, como por motivos práticos isso não é possível nos grandes Estados, elege-se uma comissão de pessoas confiáveis para tomar essas decisões: o Parlamento. Da mesma maneira, o governo é uma comissão do Parlamento. Porém, o essencial do Parlamento não é ser uma comissão eleita pelo povo para tomar decisões em seu nome, mas no seu modo de trabalhar baseado "num conflito de opostos e de opiniões, que resulta na vontade correta do Estado. O essencial do Parlamento é, portanto, a discussão pública de argumentos e contra-argumentos, os debates e conversações públicas e a parlamentação, que no entanto ainda não é democracia".

${ }^{189}$ Cf. Schmitt (1996, p. $\left.5-7\right)$.

190 Schmitt (1996, p. 10) ressalta que "a crença no sistema parlamentar, num government by discussion, pertence ao mundo intelectual do liberalismo. Não pertence à democracia".
} 
composto por meio do sufrágio universal, tornou-se o lugar do dissenso e da expressão política dos conflitos sociais, inicialmente conflitos de classes e, atualmente muito mais difusos.

Nesse contexto, a tomada de decisões mediante discussões públicas, entendidas como "intercâmbio de opiniões com o objetivo de convencer o opositor de algo verdadeiro ou correto, por meio de argumentos racionais", é extremamente dificultada pelo próprio grau de divergência e conflituosidade social dos membros do Parlamento.

Tal situação é agravada pelo fato de a argumentação ter sido substituída por "negociações entre partidos", “contabilização calculista dos interesses e das chances de poder" e "manipulação das massas"191. Portanto, "não se trata mais de convencer o opositor de uma verdade ou de uma atitude correta, mas sim de conquistar a maioria, para exercer o poder por meio dela" (SCHMITT, 1996, p. 8).

Isso compromete a capacidade de o Parlamento produzir normas que direcionem a ação do Estado para a concretização dos direitos econômicos e sociais.

Numa linha de crítica não democrática, Schmitt (1996, p. 9) afirma que já na década de 1920, o Parlamento funcionava "só sofrivelmente como um instrumento útil e até imprescindível de técnica social e política”. E a explicação para isso, segundo o autor (1996, p. 15 - 16), encontrava-se nas "condições da moderna democracia de massas", a qual, com o intuito de "concretizar uma identidade de governantes e governados", busca eliminar a independência dos representantes em relação aos eleitores, enquanto que o Parlamento liberal exige uma discussão entre membros independentes.

Além disso, Schmitt (1996, p. 47 - 48) salienta que a publicidade e a discussão, princípios sobre os quais se estruturava o sistema parlamentar, deveriam ser os instrumentos mediante os quais se chegaria à verdade e à justiça e se garantiria a vitória do direito sobre a força. Porém, "as grandes decisões que determinam hoje os destinos das pessoas não são mais (se é que foram um dia) o resultado de um balanceamento de opiniões, num discurso e contradiscurso público, e não são o resultado de debates parlamentares". As condições concretas levaram o trabalho parlamentar a se concentrar nas comissões e transformaram o plenário (e a publicidade das discussões) em simples fachada. Assim, "aquilo que os representantes dos grandes interesses capitalistas decidem em comitês fechados é talvez mais importante do que quaisquer decisões políticas para o

\footnotetext{
${ }^{191}$ Nesse sentido, Schmitt (1996, p. 6) salienta que "em algumas nações o sistema parlamentar conseguiu transformar todas as questões públicas em objeto de cobiça e de compromisso dos partidos e dos agregados, e a política, longe de ser a ocupação de uma elite, passou a ser a desprezível negociata de uma desprezível classe de gente".
} 
dia-a-dia e o destino de milhões de pessoas". Consequentemente, o Parlamento, que surgiu para controlar os líderes absolutos mediante a publicidade do processo deliberativo, não consegue mais realizar seu papel. Como "a publicidade e a discussão passaram a ser só uma formalidade vazia e inócua, então o Parlamento, do modo como se desenvolveu no século XIX, também perdeu, desde então, o seu fundamento e o seu sentido" (SCHMITT, 1996, p. $47-48)$.

Mais recentemente, em uma linha semelhante à do referido autor, Caggiano (2003, p. 147 - 148) aponta que a incapacidade de o Parlamento dar as respostas exigidas nos momentos de crises econômicas e políticas agudas decorre de diversos fatores, como a universalização do sufrágio e a doutrina marxista, as quais fizeram com que chegassem aos Parlamentos representantes com ideologias muito diferentes, o que dificulta o consenso e torna lento o trabalho parlamentar ${ }^{192}$.

De fato, com a universalização do sufrágio, o Parlamento se tornou o local do dissenso e do conflito entre interesses antagônicos. Entretanto, essas divergências simplesmente expressam, politicamente, os conflitos sociais, o que é uma característica indissociável do Parlamento em uma sociedade verdadeiramente democrática e pluralista. Portanto, a universalização do sufrágio nada mais fez do que politizar os conflitos socioeconômicos, pois, antes disso, somente os interesses da classe dominante estavam politicamente representados. Assim sendo, não se pode imaginar como caminho para a revitalização do Parlamento a criação de mecanismos para redução da representação política das divergências e divisões da sociedade.

Resta, somente, combater os interesses egoísticos dos representantes mediante mecanismos que, simultaneamente, os desestimulem e incentivem comportamentos voltados para os interesses coletivos, ${ }^{193}$ bem como instrumentos que permitam um melhor processamento das divergências.

Esse alto grau de divergências causado pela diversidade de correntes parlamentares torna ainda mais lento o processo legislativo, o qual, desde suas origens já não apresentava a rapidez da esfera econômica e do Executivo, pois se trata de um tempo

\footnotetext{
${ }^{192}$ A propósito, Ferreira Filho autor (1968, p. 100) salienta que "de fato, à medida que o Estado se imiscuía no domínio econômico e no domínio social, para proteger os economicamente fracos, os Parlamentos se viram cada vez mais impossibilitados de desempenhar as tarefas que dele eram esperadas". E acrescenta: "de certo modo, o Parlamento se tornou o terreno onde as massas procuravam conquistar as benesses que economia lhes recusava". Ocorrera uma cisão entre poder político e poder econômico, pois os grupos que queriam mudar o sistema econômico vigente ampliavam sua presença no Parlamento.

${ }^{193}$ Assunto que será discutido no Capítulo 3.
} 
inerente às deliberações baseadas em discussões e debates, ${ }^{194}$ fator que contribuiu decisivamente para a transferência de poder normativo para o Executivo (assunto da próxima seção).

A criação de comissões parlamentares especializadas em determinados setores da ação estatal, o que, inclusive, já acontece, é um caminho para enfrentar essa situação. Todavia, para que se tenha êxito, o parlamentar deve pertencer a uma ou a duas comissões no máximo e nela permanecer por um longo período, pois em caso contrário não haverá especialização. Mesmo assim, os parlamentares necessitam da ajuda de especialistas, os quais nem sempre se mostram neutros diante das matérias analisadas (FERREIRA FILHO, 1968, p. $111-112$ ).

Porém, apesar da existência dessas comissões, o que algumas pesquisas demonstraram ocorrer, na verdade, é a centralização do processo decisório, pois há um alto grau de delegação de poderes dos parlamentares para os líderes partidários no Congresso Nacional brasileiro (FIGUEIREDO, 2003a, p. 65).

O Regimento Interno da Câmara limita o fortalecimento e a modernização do Legislativo, pois mantém a direção do processo legislativo nas mãos do colégio de líderes, convergindo exclusivamente para o plenário e prejudicando o trabalho das Comissões (mesma forma de funcionamento vigente durante o regime militar). $\mathrm{O}$ poder do colégio de líderes se encontra nos fatos de que os lideres: juntamente com o Presidente da Mesa Diretora definem a pauta de proposições a serem apreciadas; manifestam-se em nome de toda a bancada que lideram, os líderes controlam requerimentos de votações nominais, destaques para a votação em separado e tramitação urgente das matérias, o que retira os projetos do "âmbito de influência das comissões e restringe a apresentação de emendas no plenário"; e indicação e substituição dos membros das Comissões. Dessa forma, ocorre uma "preponderância de um pequeno grupo de parlamentares cujas decisões acabam por se sobrepor às dos demais", o que implica "a desvalorização da própria atividade parlamentar". 195

Estudos empíricos demonstraram, todavia, que há diferenças significativas quanto ao trabalho das Comissões Permanentes na Câmara dos Deputados e no Senado.

\footnotetext{
${ }^{194}$ Cf. Caggiano (2003, p. $147-148$ ).

${ }^{195}$ O colégio de líderes é comporto pelo presidente da Câmara e líderes da maioria, da minoria, dos partidos e dos blocos parlamentares, sendo-lhe conferida pelo regimento interno o estatuto de órgão auxiliar da Mesa Diretora da Casa nas principais tarefas relativas à organização dos trabalhos legislativos. Em especial, cabe a esse colegiado, juntamente com o presidente da Mesa, a elaboração da agenda com a previsão das proposições a serem apreciadas no mês subseqüente, em conformidade com a qual o presidente designa a ordem do dia (FIGUEIREDO; LIMONGI, 2001, p. 46 - 48 e FIGUEIREDO, VALENTE 1999, p. 52 - 53).
} 
Enquanto naquela têm um papel pouco relevante, pois os projetos costumam ser aprovados pelo Plenário sem seu parecer, devido a pedidos de urgência de lideranças, neste, os projetos passam por elas e são aprovados, em sua maioria, por decisão terminativa, ou seja, sem a necessidade de serem submetidos à votação pelo Plenário (FIGUEIREDO; LIMONGI, 2001, p. 60).

O formato decisório centralizado no colégio de líderes e o esvaziamento das Comissões (que deveriam exercer o papel de instância especializada de apreciação legislativa pela qual todas as proposituras deveriam passar antes de serem apreciadas pelo Plenário) favorecem a determinação do conteúdo, do tempo e do ritmo dos trabalhos no Congresso Nacional pelo Poder Executivo, como se verá melhor adiante (FIGUEIREDO; LIMONGI, 2001, p. 55 - 56).

Outra característica do Parlamento demonstrada por estudos empíricos é que se trata de uma instituição elitista, porque há um grupo restrito de parlamentares que, efetivamente, impõe as decisões a todos os demais membros. Essa elite parlamentar pode ser definida como "um grupo seleto de parlamentares cujos membros se destacam dos demais participantes do Congresso Nacional em função das posições que ocupam, dos interesses que representam e/ou da reputação alcançada" (GUIMARÃES, 2000, p. 1 2). ${ }^{196}$

Portanto, embora ideológica e formalmente se presuma que exista uma igualdade entre os membros do Parlamento, na prática, constata-se que uma elite participa efetivamente das negociações e da tomada de decisões, enquanto a grande massa de parlamentares se apresenta como liderados (GUIMARÃES, 2000, p. 15).

Isso demonstra a necessidade de reformas institucionais profundas a fim de democratizar e descentralizar o processo legislativo, pois não se pode atribuir a missão institucional de exercer o controle democrático do poder político a uma instituição que, em seu próprio processo decisório não, é plenamente democrática. Além disso, é necessário ampliar o papel das Comissões Permanentes para que o Congresso atenda mais prontamente às demandas da sociedade.

Observa-se, também, que, embora a oposição seja fundamental para o controle do poder político, existem importantes dificuldades para o desempenho de seu papel.

A oposição consiste na "força legítima produzida por um ou mais partidos para atuar no âmbito do parlamento contra outra força parlamentar que, tendo por base também

\footnotetext{
${ }^{196}$ A pesquisa citada abrange o período compreendido entre 1988 e 1994.
} 
o apoio de um partido ou de vários partidos, mantém no poder um determinado governo". Nos sistemas democráticos, ela constitui "a forma legítima de contestar o poder estabelecido - sem pretender removê-lo em suas bases - e formular um programa alternativo de governo, valendo-se para tanto da organização partidária como instrumento de luta política" (BONAVIDES, 2004, p. 291). Diante disso, o referido autor (2004, p. 291) conclui que a oposição ${ }^{197}$ é “a peça-chave do parlamento democrático contemporâneo". Desta maneira, "a ausência de oposição ou seu quebrantamento configura um estado de enfermidade do organismo representativo ou pelo menos uma tendência incipiente ao afrouxamento da legitimidade democrática com a perda de alternativas", pois o Parlamento é "a instância mais alta e qualificada para exprimir as dissidências de opinião" (BONAVIDES, 2004, p. 292).

Bonavides (2004, p. 294) ainda destaca que "a mudança é parte essencial dos sistemas representativos de feição democrática e só há mudança com formas alternativas de poder, ou seja, com a possibilidade de a Oposição de hoje se converter amanhã em Governo e vice-versa ${ }^{198,}$.

Além disso, a oposição cumpre o papel de dar publicidade ${ }^{199}$ às alternativas políticas que tem em relação à maneira como o Governo está sendo conduzido, discutindo as políticas e decisões administrativas que são tomadas (GRIFFITH, RYLE, WHEELERBOOTH, 1989, p. 10).

Para tanto, os debates parlamentares devem repercutir nos jornais, nos rádios, na televisão (GRIFFITH, RYLE, WHEELER-BOOTH, 1989, p. 518) e nas conversas da população nos mais diferentes espaços públicos e privados.

Existem vários mecanismos institucionais para proteção da minoria oposicionista, como, por exemplo: garantia de participação da minoria em todos os debates legislativos; composição proporcional das comissões parlamentares; direito de ter incluídas suas proposituras na ordem do dia; exigência de maiorias qualificadas ou até de consenso para a aprovação de decisões políticas mais relevantes ${ }^{200}$. Além disso, existem muitos

\footnotetext{
${ }^{197}$ Loewenstein $(1986$, p. 242) aponta que a distribuição do poder entre maioria e minoria, a fim de que esta não se submeta ao domínio tirânico daquela, é uma importante espécie de controle intra-órgão no Parlamento.

${ }^{198}$ A função da oposição é se opor ao Governo para convencer o eleitorado a substituir os governantes que se encontram no poder pelo partido de oposição, a fim de que possa implementar as políticas que acredita serem as melhores para a nação. A atuação da oposição não pode ser somente crítica, mas também construtiva, apresentando suas propostas políticas alternativas (GRIFFITH, RYLE, WHEELER-BOOTH, 1989, p. 338).

${ }^{199}$ Nesse sentido, Griffith, Ryle e Wheeler-Booth (1989, p. 517) afirmam que "the succes of a democracy is to be judged by the extend to which it can ensure that the Government is publicly accountble".

${ }^{200}$ Nesse sentido, ver Loewenstein $(1986$, p. $243-245)$.
} 
mecanismos de controle ${ }^{201}$, no sentido de fiscalização, que podem ser usados pela oposição, como pedido de informações, convocação de ministros e criação de comissões parlamentares de inquérito.

Todavia, observa-se que esses mecanismos têm surtido poucos resultados diante das dificuldades de se responsabilizar os culpados por infrações político-administrativas e de se impor correções de rumos a partir dos fatos apurados.

Por fim, há um elemento histórico-cultural do Estado brasileiro que limita drasticamente as possibilidades de o Parlamento exercer o controle democrático do poder político: o patrimonialismo. Predomina no Brasil, desde os tempos da colonização, a confusão entre o público e o privado. A cultura do favorecimento dos amigos, da formação de clientelas políticas e a naturalização da corrupção continuam a impedir que o Estado brasileiro, e em especial o Parlamento, constituam verdadeira esfera pública, ou seja, um espaço de mediação dos interesses coletivos em que todos os interessados sejam igualmente considerados. Essa indiferenciação entre o público e o privado no desenvolvimento das atividades parlamentares tem como resultado o desinteresse em se promover o controle democrático do poder com o objetivo de se concretizar os direitos econômicos e sociais. Isso porque controle, transparência, responsabilização e criação de direitos não interessam à cultura patrimonialista, que prefere a opacidade, a irresponsabilidade política e a o clientelismo.

No próximo capítulo serão discutidos alguns mecanismos institucionais que contribuem para coibir as práticas patrimonialistas, mão somente com mudanças nas instituições não se muda uma cultura com raiz de mais de quinhentos anos.

\subsection{Transferência de Poder Normativo do Parlamento para o Executivo.}

Diversos fatores já analisados no capítulo anterior provocaram o crescimento das demandas da sociedade civil em relação ao Estado, o qual deixou de ser mero garantidor da ordem e árbitro das relações sociais e assumiu novos papéis, como a prestação de serviços públicos a fim de assegurar direitos sociais. Além disso, a tendência oligopolista da economia capitalista (empresas transnacionais, formação de blocos econômicos, aumento da concentração do poder econômico prejudicando a livre concorrência etc.) diminuiu a capacidade de auto-regulação do mercado, exigindo-se

${ }^{201}$ Cotta (1995, p. 886) afirma que, normalmente, o Parlamento se divide entre uma maioria ligada ao Governo e a minoria da oposição. Na função legislativa, a primeira tem um papel preponderante. Já na função de controle, é a segunda que se destaca. Por isso, deve haver um "razoável equilíbrio" entre maioria e oposição, pois isto constitui "a base de uma dialética política viva". 
controles estatais sobre as atividades produtivas mediante a edição de normas, criação de empresas estatais e outras medidas indutoras de política econômica. ${ }^{202}$ A crise do Estado Social e a proposta neoliberal ${ }^{203}$ de se estabelecer um Estado mínimo e forte, mediante a redução dos serviços sociais prestados diretamente e sua atuação na economia apenas como agente regulador, em nada alterou a exigência de uma atuação estatal célere e pronta, nem a quantidade nem a qualidade da demanda legislativa. Tal situação favoreceu o fortalecimento do Poder Executivo, pois coube a ele, por suas próprias características, a prestação dos serviços e a intervenção no domínio econômico, bem como a liderança política.

Como o Estado age sob o princípio da legalidade, seus novos papéis levaram a uma ampliação considerável do número de leis e de outros instrumentos normativos, como atos e contratos administrativos. Além de aumentar em quantidade, as leis mudaram em qualidade ${ }^{204}$, pois deixaram de apenas declarar regras éticas pré-existentes com a finalidade de manter a ordem, para tornarem-se instrumentos para consecução das políticas econômicas e sociais, que visam muito mais à transformação da realidade social do que sua conservação. Exige-se, portanto, uma legislação numerosa, técnica, flexível e altamente adaptável. Entretanto, o Parlamento se mostrou incapaz de editar leis na quantidade e da qualidade que lhe são demandadas, havendo uma tendência de transferência de boa parte da função legislativa para o Poder Executivo, por ser mais ágil e dotado de corpo burocrático melhor preparado. ${ }^{205}$

Essa dificuldade de o Parlamento atender a atual demanda normativa decorre de duas razões principais: ausência de preparo técnico por não ser composto por especialistas;

${ }^{202}$ Cf. BOBBIO, 2000, p. 136 - 141, CLÈVE, 1993, p. 34 - 40, FRISCHEISEN, 2000, p. 99, FARIA, 1988, p. $41-42$.

${ }^{203}$ O Neoliberalismo apresentou duras críticas ao modelo de Estado Social, por entender que era demasiadamente grande e, por conseqüência, ineficiente e maligno, retomando a idéia de que o Estado deve ser limitado, reduzindo suas funções e sua intervenção na economia (ROSE; MILLER, 1992, p. 198 - 201).

${ }^{204}$ Trata-se de um direito que deixa de ser meramente formal e se materializa, ou seja, apresenta um grande número de intervenções de controle legal sobre áreas classicamente auto reguladas, como a economia, em virtude do aparecimento do fenômeno do poder econômico e da necessidade de proteção social. Esse direito material se apresenta como um instrumento para implantação de políticas de governo que devem atingir resultados sociais. Diante disso, enquanto o direito formal encontra sua legitimação na delimitação de esferas reservadas à autonomia privada, o material vai encontrá-la nos resultados sociais obtidos com a regulação. Em síntese, trata-se de um direito que tem como função a implantação dos objetivos do Estado Social, legitima-se pelos resultados que proporciona, e em sua estrutura tende a ser particularístico, orientado para determinados propósitos, e requer a assistência das ciências sociais (TEUBNER, P. 14 - 19).

${ }^{205}$ Cf. CLÈVE, 1993, p. 49 - 50, FERREIRA FILHO, 2003, p. 156. 
e a impossibilidade de o processo legislativo ser célere, em virtude de sua solenidade, dos numerosos espaços para procrastinações e à sua estrutura colegiada e numerosa. ${ }^{206}$

O método de trabalho do Parlamento não permitia que desempenhasse as funções que se esperava dele, pois estava organizado como um "centro de discussão", no qual opiniões deveriam ser conciliadas, o que, diante das divergências internas, gerava discussões prolongadas que obstruíam a deliberação e impediam que decisões fossem tomadas com a rapidez exigida pela atuação do Estado na esfera econômica, a qual exige ainda uma flexibilidade impossível de ser obtida pela forma de trabalho do Parlamento (FERREIRA FILHO, 1968, p. 101).

Em um posicionamento firmado no contexto do regime autoritário e marcado por traços antidemocráticos, Ferreira Filho (1968, p. 12) afirmou que, além de não conseguir desempenhar sua função legislativa com a celeridade necessária, os Parlamentos não conseguiriam fazê-lo de modo satisfatório mesmo lentamente, devido, além dos fatores já mencionados, ao fato de que "o modo de escôlha de seus membros torna-os pouco freqüentados pela ponderação e pela cultura, mas extremamente sensíveis à demagogia e à advocacia em causa própria".

Observou-se, então, uma tendência à paralisia decisória dos Parlamentos, em virtude da qual passaram a "paulatinamente abdicar de sua hegemonia e de sua preeminência", sobretudo a partir de 1920, passando a delegar poderes legislativos para o Executivo $^{207}$ (FERREIRA FILHO, 1968, p. 99 - 102). De acordo com Rocha (2004, p. 188), o "Estado contemporâneo não funciona sem mecanismos de transferência de função legislativa para o Executivo ${ }^{208,}$.

Grau (2008, p. 231) diferencia a atuação normativa do Parlamento e do Executivo, explicando que aquele produz normas incidentes sobre "situações não momentâneas, isto é, estáveis”, enquanto que "as situações que reclamam uma atuação do

206 Cf. CLÈVE, 1993, p. 51, CUÉLlAR, 2001, p. 114, FERREIRA FILHO, 2003, p. 157, 182, FRISCHEISEN, 2000, p. 99 - 100, CAGGIANO (2003, p. 153) e CAETANO (1963, p. 165). LOCKE (2003, p. 116 - 117) já chamava a atenção para o fato de o Parlamento ser "numeroso e lento para acompanhar a rapidez que a execução requer", bem como a impossibilidade de prever nas leis todos os problemas com o qual o governo constantemente se depara, e o risco da rigidez das leis, de maneira que "existe certa flexibilidade no poder executivo para levar a efeito muitas ações que as leis não prescrevem ditadas pela discrição".

${ }^{207}$ Esse fato também ocorreu nos Estados Unidos e na Inglaterra (SCHWARTZ, 1966, p. 34).

${ }^{208} \mathrm{O}$ poder normativo do Executivo, no caso brasileiro, dá-se por meio da iniciativa de propositura de projetos ou pela atuação direta, por exemplo, com as Medidas Provisórias (CLÈVE, 1993, p. 93), as quais são controladas pelo Parlamento em seus aspectos jurídico (pressupostos de edição) e político (conveniência), podendo aprová-las ou não (CLÈVE, 1993, p. 176), além da atuação normativa das agências reguladoras. Entretanto, na prática, esse controle não se mostra eficiente. 
Executivo, no exercício de uma capacidade normativa de conjuntura, são nitidamente de natureza momentânea”.

Essa capacidade normativa de conjuntura será exercida, sobretudo, com relação à atividade de intermediação financeira, a qual, devido a seu caráter técnico e à exigência de celeridade, mostra-se incompatível com o tempo do processo legislativo (GRAU, 2008, P. 233).

Portanto, como assevera Grau (2008, p. 232), o direito - tal como divisou Von Ihering, em sua teoria organicista - necessita, como todo organismo vivo, estar em constante mutação, impondo-se a superação do descompasso existente entre o ritmo de evolução das realidades sociais e a velocidade de transformação da ordem jurídica. Nesse clima, a instabilidade de determinadas situações e estados econômicos, sujeitos a permanentes flutuações - flutuações que definem seu caráter conjuntural -, impõe sejam extremamente flexíveis e dinâmicos os instrumentos normativos de que deve lançar mão o Estado para dar correção a desvios ocorridos no desenrolar do processo econômico e no curso das políticas públicas que esteja a implementar.

Em virtude desses fatos, o Parlamento, que classicamente era considerado o "poder dos poderes" por ser o que "de mais perto representaria o soberano" e o detentor do monopólio da atividade legislativa (FERREIRA FILHO, 2003, p. 154 - 155), perdeu essa posição, reduzindo sua importância no cenário político (PALUDO, 1999, p. 135). O Executivo assumiu o primado entre os poderes, fenômeno que se acentuou com o surgimento das agências reguladoras $^{209}$, as quais, com sua independência hierárquica e autonomia financeira, assumiram poderes normativos, fiscalizatórios e sancionatórios, passando a constituir "lócus privilegiado não apenas da ação especializada tecnocrática, mas também da própria mediação política, em detrimento do Poder Legislativo" (TOJAL, 2002, p. 5).

\footnotetext{
${ }^{209}$ As agências reguladoras foram concebidas para suprir a deficiência técnica do Legislativo. Caracterizadas por serem técnicas, especializadas e, em tese, imparciais, por serem dotadas de independência política, poderiam, agir com mais rapidez e eficácia do que o Legislativo na normatização de sua área de atuação. A legitimação de sua atuação normativa, apesar de não serem órgãos de representação democrática, decorreria: de sua finalidade (busca de eficiência); de sua forma de atuação; de sua instituição por lei aprovada pelo Parlamento; e das próprias atividades que desempenham. Além disso, poderiam representar uma alternativa à representação político-eleitoral diante de sua crise, decorrente da incapacidade de responder à "crescente complexidade social", porque permitem a participação direta da sociedade por meio da manifestação dos indivíduos, diretamente interessados ou não, sobre o conteúdo de seus diplomas normativos (CUÉLLAR, 2001, p. $131-135)$.
} 
Esse desequilíbrio entre os Poderes, ${ }^{210}$ com a concentração de poderes normativos no Executivo, representa uma ameaça para a democracia ${ }^{211}$. Exemplo disso é o fato de que a quantidade de medidas provisórias editadas pelo Executivo demonstra que ele tem "substituído o Congresso não somente na tomada de decisões políticas fundamentais, mas no próprio estabelecimento da agenda política do País” (ROCHA, 2004, p. 72).

Rocha (2004, p. 69 - 70) explica que o crescimento da burocracia responsável pela regulação financeira ocorreu como "uma reação contra as tendências antidemocráticas das forças do mercado". Entretanto, a própria burocracia começou a "representar uma ameaça contra a liberdade e a democracia”. Desta maneira, a regulação financeira apresenta um grande paradoxo: "ela só nos torna mais livres mediante o alto preço da delegação, para uma tecnocracia altamente especializada, do poder de criar as regras jurídicas que sustentam as instituições sem as quais não podemos viver”.

Como a necessidade de regulação dos serviços públicos e do mercado financeiro, por meio da capacidade normativa de conjuntura dos órgãos do Poder Executivo, é indispensável, o que se precisa discutir é "como regular de forma a conciliar efetividade e democracia" (ROCHA, 2004, p. 69).

O pensamento jurídico-político dominante, invocando o princípio da separação de poderes, resiste em aceitar a constitucionalidade das normas editadas por órgãos do Poder Executivo, como o Conselho Monetário Nacional e o Banco Central do Brasil ${ }^{212}$. Todavia, o poder normativo desses órgãos se revela efetivo, pois "os agentes econômicos e os órgãos estatais respeitam e acatam essas normas"213. Outra linha doutrinária assume a premissa realista, segundo a qual "a complexidade técnica das atribuições da burocracia exige que lhe seja conferido um poder normativo de conjuntura", e tenta "reformular categorias e esquemas interpretativos" (ROCHA, 2004, p. 11 - 13).

\footnotetext{
${ }^{210}$ Cf. SCHWARTZ, 1966, p. 27.

${ }^{211}$ Ferreira Filho pondera que, se por um lado a outorga de poderes normativos para Executivo ameaça a democracia por dar margem a arbitrariedades, recusar realizar essa transferência "pode destruí-la", devido à ineficiência decorrente (FERREIRA FILHO, 1968, p. 14).

212 A atuação dos órgãos reguladores financeiros e de serviços públicos é tão abrangente, que eles desempenhem as três funções clássicas do Estado, pois "praticam atos administrativos, criam direito, incumbem-se de sua interpretação e aplicação" (julgam), e "não somente implementam, como formulam políticas públicas" (ROCHA, 2004, p. 64).

${ }^{213}$ Rocha $(2004$, p. $27 ; 31)$ assinala que a primeira linha, que pode ser definida como liberal, "é desafiada a todo momento pela profusão de normas jurídicas sem as quais o mercado se desestruturaria e o Estado não teria como interferir no domínio econômico também para perseguir outras finalidades que não a mera preservação do sistema econômico". Tais normas, constituídas por resoluções, circulares, comunicados e portarias, versam, por exemplo, sobre contratos privados (como consórcios e financiamentos), política monetária, expansão e contração do crédito, circulação de capital estrangeiro etc., as quais interferem decisivamente na vida das pessoas.
} 
Rocha (2004, p. 68) defende que, diante do fato de a indispensável competência normativa dos órgãos reguladores do mercado financeiro brasileiro gerar um déficit democrático ${ }^{214}$ da formulação de políticas públicas, “o controle judicial é necessário para garantir a legitimidade democrática do processo administrativo". Isso porque, "como o cidadão comum não dispõe nem do conhecimento técnico nem dos meios materiais necessários para acompanhar o processo de tomada de decisões, o controle judicial deveria funcionar como um mecanismo de controle democrático da regulação financeira”.

Entretanto, para que seja possível realizar esse controle, em primeiro lugar, é preciso reconhecer que a função regulamentar do Executivo é uma prática legítima e constitucional $^{215}$ (GRAU, 2008, p. 254).

Rocha (2004, p. 108) afirma que a "capacidade normativa de conjuntura" da burocracia reguladora deve se submeter a três tipos de restrição:

(i) ela não pode estabelecer as regras de sua própria produção, ou seja, o CMN e o BCB não têm competência para definir sua própria competência; (ii) ela deve estar fundamentada numa lei em sentido formal; (iii) sua legitimidade não é garantida somente pela efetividade das normas editadas, ou seja, pela capacidade dos reguladores financeiros de preservarem, de um lado, o regime monetário que garante a reprodução do regime de acumulação, e, de outro, a coesão social - ela somente será legítima se for exercida mediante um procedimento que garanta essa gênese democrática.

A essas restrições apontadas por Rocha, acrescenta-se a necessidade da submissão material dessas normas à Constituição ${ }^{216}$.

Rocha (2004, p. 195) propõe como forma de enfrentar o "déficit democrático da regulação financeira" o controle judicial da burocracia.

Entende-se que o controle judicial é um mecanismo importante, como se discutirá posteriormente. Porém, o Parlamento, como órgão representativo por excelência, também deve cumprir seu papel no controle da função normativa do Executivo.

\footnotetext{
${ }^{214}$ Rocha (2004, p. 190) afirma que recuperar o realismo é o primeiro passo para que o direito público enfrente o "déficit democrático da regulação financeira".

${ }^{215} \mathrm{O}$ poder normativo do Executivo é formalmente justificado por sua previsão na Constituição e nas leis aprovadas pelo Parlamento. Sob o aspecto material, aponta-se uma exigência fática, pois a flexibilidade regulamentar é mais eficiente do que a rigidez legal na normatização da tecnologia em constante processo de evolução (CLÈVE, 1993, p. 219 - 221). Grau (2008, p. 243 - 244) assinala que "o exercício da função regulamentar, pelo Executivo, não decorre de uma delegação de função legislativa", mas na própria atribuição de poder normativo do Executivo. Isso porque "o Legislativo não é titular de monopólio senão da função legislativa, parcela da função normativa, e não de toda esta".

216 Nesse sentido, Grau (2008, p. 232) afirma que todos os atos regulatórios decorrentes da capacidade normativa de conjuntura devem ser coerentes com o disposto na Constituição e nas leis.
} 
Diante da falta de conhecimentos técnicos de seus membros, os Parlamentos procuram se cercar de especialistas e os lobbies procuram levar informações a eles. Todavia, os assessores nem sempre são capazes de suprir todas as necessidades de informações e, muitas vezes, não colaboram, mas realizam a análise das questões técnicas no lugar dos parlamentares, o que não resolve o problema do déficit de representatividade, pois, embora sejam subordinados a representantes do povo, também não são eleitos diretamente. Além disso, as informações levadas pelos lobbies são carregadas de interesses particulares. $^{217}$

Procurou-se, também, manter a participação do Parlamento na produção legislativa, sem comprometer a prontidão exigida do governo, por meio de leis quadros, ou seja, normas gerais que fixam princípios e objetivos a serem atingidos, delegando-se ao Executivo a competência para a elaboração de normas específicas sobre a matéria ${ }^{218}$ (CLÈVE, 1993, p. 131 - 132).

A produção de leis fixando diretrizes ${ }^{219}$, de fato, é um caminho, porém a delegação da função legislativa deve ser acompanhada por uma rigorosa supervisão do Parlamento sobre as atividades que delegou, por ser constituído pelos representantes eleitos pelo povo, sob pena de colocar o administrador numa situação de "quase completa irresponsabilidade" (SCHWARTZ, 1966, p. 74 - 75).

Além disso, se "legislador democraticamente legitimado deste Estado não quiser deixar à administração e aos tribunais a tomada de medidas de fundamental alcance sócio-político ou de amplas repercussões a este nível, não se pode limitar à edição de normas gerais e abstractas", devendo, também, editar normas que influenciem diretamente a organização social, política e econômica (PIÇARRA, 1989, p. 256).

\footnotetext{
${ }^{217}$ Cf. CLÈVE, 1993, p. 51 e CUÉLLAR, 2001, p. 130 - 131.

${ }^{218}$ Ferreira Filho $(1968$, p. 240 - 242) propõe que as leis destinadas a servir de instrumentos para políticas públicas, especialmente em matéria econômica, deveriam ser elaboradas pelo Executivo depois de autorizado pelo Parlamento que fixaria algumas diretrizes. Poderia, ainda, um terço dos parlamentares requerer sua apreciação, podendo ser rejeitado pelo voto da maioria absoluta de seus membros. Deveria ainda haver ampla publicidade sobre os objetivos do estabelecimento de novas regras. Propõe, ainda, a possibilidade de o governo, em casos de urgência, estabelecer normas sem a autorização prévia do Parlamento, porém ficariam sujeitas à sua ratificação, sob pena de perderem sua vigência se não ratificadas em determinado prazo. Com esse desenho institucional, competiria ao Parlamento, sobretudo, o exercício do controle político, fiscalizando tanto os detalhes e as irregularidades administrativas como a definição da política global do governo.

${ }^{219}$ Quanto às políticas públicas, por exemplo, Bucci $(2001$, p. 259 - 260) afirma que sua configuração geral, "as diretrizes, os objetivos, são opções políticas que cabem aos representantes do povo e, portanto, ao Poder Legislativo, que as organiza sob a forma de leis, para execução pelo Poder Executivo, segundo a clássica tripartição de funções estatais em legislativa, executiva e judiciária. Entretanto, a realização concreta das políticas demonstra que o próprio caráter diretivo do plano ou programa implica a permanência de uma parcela da atividade "formadora" do direito nas mãos do governo, Poder Executivo, perdendo-se a nitidez da separação entre os dois centros de atribuições".
} 
Conclui-se, que a transferência de funções normativas do Parlamento para o Executivo, sobretudo em matéria econômica, é inevitável, diante das próprias características do processo legislativo. Além disso, representa uma necessidade para a concretização dos direitos econômicos e sociais, pois isto exige a regulação da economia. Todavia, essa função do Executivo só pode ser realizada dentro dos parâmetros constitucionais e legais fixados pelo Parlamento, sendo que, em caso de não serem respeitados, a burocracia deve se submeter ao controle tanto do Judiciário como do Parlamento, cabendo a este último a responsabilização política e a correção de rumos.

\subsection{Tecnificação e Falsa Despolitização das Decisões Políticas.}

O Parlamento sofre grande limitação ema sua atuação no controle democrático do poder político com objetivo de contribuir com a concretização dos direitos econômicos e sociais em virtude da tecnificação e da falsa despolitização das decisões políticas. Esse problema se manifesta de maneira mais acentuada no governo da economia ${ }^{220}$, área que costuma ficar circunscrita aos técnicos dos órgãos governamentais que procuram isolar suas decisões da influência política, invocando a neutralidade técnica ou a inviabilidade de outros caminhos.

Nota-se que "a hipertrofia do Poder Executivo e a fragilidade do sistema de representação política fazem com que a gestão econômica assuma um caráter nãodemocrático". Isso porque, as "equipes econômicas - constituídas de acadêmicos em geral recrutados fora da carreira burocrática e do sistema partidário - tomam decisões de forma autônoma e frequientemente impermeável às pressões dos políticos ou de grupos organizados na sociedade",221 (LOUREIRO, 1997, p. 172).

\footnotetext{
${ }^{220}$ Loureiro (1997, p. 145) assinala que em toda a América Latina alguns traços comuns na gestão da economia, como: a "hipertrofia do Poder Executivo, em detrimento do Legislativo, na condução das políticas reguladoras e desenvolvimentistas"; "a forte autonomia das burocracias estatais"; a hegemonia das políticas deflacionistas baseadas no "Consenso de Washington", com uma "americanização" das elites tecnocráticas. O autor (1997, p. 171) observa que nas democracias menos consolidadas a influência dos tecnocratas economistas no governo é muito maior do que nas democracias estáveis, atuando como verdadeiros dirigentes políticos, e não como assessores destes.

221 Mesmo com a democratização, a formulação da política econômica continuou concentrada em um "pequeno grupo de especialistas" que não consultam o Parlamento, os partidos ou grupos organizados, sob o argumento da gravidade das crises econômicas e da necessidade de "medidas governamentais fortes e rápidas" (LOUREIRO, 1997, p. 172). Santos (1997a, p. 363 - 364) afirma que o governante, para empreender as reformas estruturais, deve manter o processo de decisão o mais aberto possível, passando pelo aval do Congresso Nacional, e, portanto, tornando-o visível às mais fortes e diversificadas pressões dos grupos sociais, às interferências do Judiciário, dos governadores de estado, sem falar nas custosas negociações com partidos e líderes da oposição, quando não com a própria base governista. Ou, alternativamente, o governante pode, a fim de garantir maior rapidez nas reformas, afastá-las do debate
} 
Todavia, como se discutiu no primeiro capítulo, o controle democrático também deve abranger o poder econômico, pois se isso não se realizar, não há qualquer perspectiva de concretização dos ideais do Estado Democrático de Direito. Para tanto, as decisões políticas do governo, em matéria econômica, devem se submeter ao debate público e à deliberação democrática ${ }^{222}$.

Ainda que se reconheça que a operação direta e permanente da política econômica inevitavelmente seja realizada pelos tecnocratas, no mínimo eles devem se submeter às diretrizes gerais e às metas estabelecidas pelo Parlamento, bem como serem responsabilizados perante o órgão representativo do povo por suas ações.

No entanto, tal tarefa não é simples. A seguir, passa-se a discutir as dificuldades em realizá-la.

A administração burocrática ${ }^{223}$ pode ser considerada superior às demais formas de administração, tanto por sua capacidade de aumentar a eficiência governamental, como pela forma de sua composição, já que seus quadros são selecionados segundo o critério da competência profissional, o que atende às exigências democráticas de impessoalidade e igualdade $^{224}$. Porém, como se verá, a burocratização envolve riscos para a democracia ${ }^{225}$ (FARIA, 1988, p. $49-51$ ).

A superioridade técnica da burocracia não a exime de estar subordinada aos órgãos políticos, pois não é democraticamente legitimada. Isso não que dizer que os

público mediante a restrição de sua formulação à burocracia, da mesma maneira que ocorre com as políticas monetária e cambial. Todavia, essa opção afronta os princípios democráticos.

${ }^{222}$ Analisando a experiência brasileira, Loureiro (1997, p. 117) afirma que "a exclusão das áreas monetárias e cambial do espaço de negociações e do controle efetivo do Legislativo e do Judiciário revela a fragilidade das instituições democráticas no país". Por exemplo, as negociações em torno da implementação do Plano Real se deram em torno dos grupos politicamente mais poderosos, ficando de fora os demais, como sindicatos trabalhistas. Essa prática costuma ser justificada com o velho argumento autoritário segundo o qual "a democracia pode vir a comprometer a boa gestão econômica", decorrente de uma crença equivocada (ou mal intencionada) na "oposição entre democracia e eficiência".

${ }^{223}$ Weber caracteriza a burocracia como uma forma de administração legal porque sua autoridade e legitimidade derivam da aplicação correta dos procedimentos estabelecidos nas leis. Além disso, ele a caracteriza como racional, porque deve agir buscando a adequação entre meios e fins, ou seja, por meio da definição clara dos fins almejados e do cálculo dos meios mais adequados para atingi-los, bem como do uso de regras explicitamente formuladas aplicadas num campo determinado, utilizando-se de conhecimentos especializados de maneira sistematizada dentro de um todo coerente. Esses elementos faziam com que a burocracia apresentasse uma superioridade técnica (BEETHAN, 1979, p. 104 - 111).

${ }^{224}$ A administração burocrática tem por princípio a criação de mecanismos para o recrutamento dos mais qualificados para trabalharem na Administração Pública e pela impessoalidade formalista (tratamento de todos igualmente e de acordo com regras previamente estabelecidas) (WEBER, 1964, p. 179 - 180).

${ }^{225} \mathrm{O}$ poder da burocracia perante o povo ou os políticos decorre, em primeiro lugar, da superioridade de seus conhecimentos técnicos especializados. Além disso, ela procura ampliar essa superioridade ocultando seus conhecimentos e suas ações, de maneira que a administração burocrática procura excluir o público (WEBER 1999, p. 225). 
técnicos não sejam importantes, mas não pode ser entregue a eles a possibilidade de tomar decisões políticas que definem os rumos do Estado. 226

Não obstante seu caráter impessoal e sua atuação como um instrumento administrativo eficiente do ponto de vista técnico, a burocracia (ou tecnocracia) constitui um grupo separado dentro do Estado com interesses próprios (especialmente em manter e ampliar seu poder a partir da crença de sua superioridade técnica), apresenta uma tendência inerente a ultrapassar os limites administrativos e invadir a esfera política e reflete a estrutura de classes da sociedade, sendo fortemente influenciada pelas classes das quais deriva e com que se alia (BEETHAN, 1979, p. 97 - 10; 113).

Deveria caber à burocracia somente os problemas administrativos, enquanto que aos políticos caberia a decisão sobre problemas fundamentais e em que há maior margem de escolha, porém “o crescimento da moderna organização econômica punha em risco até mesmo os mecanismos de representação e as instituições forjadas pelo liberalismo, já que a explosão do conhecimento científico e tecnológico impele o homem à especialização" (FARIA, 1988, p. 52).

Além disso, para ter seus interesses atendidos, a burocracia procura manter o Parlamento na ignorância, evitando que tenha acesso a informações e conhecimentos especiais. $^{227}$ Ao obter êxito no seu intento, os burocratas transformam os Parlamentos em espaços de representação "daqueles que são dominados pelos meios da burocracia", servindo somente para manifestar um "mínimo de aprovação" à dominação ${ }^{228}$ (WEBER, 1999, p. 226; 560).

Nesse sentido, Faria (1988, p. 55) salienta que

\footnotetext{
${ }^{226}$ Nessa linha, Weber assinala: "para que o império da lei seja efetivo, os políticos devem estabelecer um controle legislativo sobre a burocracia, apesar das tendências que os funcionários têm de ocultar o tratamento que dão aos assuntos no trabalho e apesar do fato de que, em comparação com a especialização e o conhecimento organizacional dos funcionários os políticos são amadores e ignorantes. O controle parlamentar da administração pode tornar-se efetivo apenas quando o direito de inquérito parlamentar e a possibilidade de interrogatório perante comissões de inquérito existem" (BENDIX, 1986, p. 349). Cf. Piçarra, 1989, p. 241 e Bonavides, 2004, p. 348.

${ }^{227}$ Nesse sentido, Beethan $(1979$, p. 117 - 118) comenta que "la administración tenía decidido interés em mantener mal informado el Parlamento y en conseguir oponerse eficazmente a los intentos de sus delegaciones", de maneira que "el secreto inherente al funcionamiento burocrático estaba em conflicto inmediato com la clarividência necessária a la actividade parlamentaria".

${ }^{228}$ Por esse motivo, Weber assinala que manter a burocracia sujeita ao controle político consiste em "uno de los problemas más importantes de la política moderna" (BEETHAN, 1979, p. 147). Faria (1988, p. 52) assinala que "com a finalidade de evitar eventuais conseqüências antidemocráticas da crescente racionalização formal e os riscos inerentes a uma dominação exclusivamente burocrática, Weber procurou contrapor o tecnocrata tanto ao empresário capitalista - aquele que, no âmbito de seu círculo de interesses, seria superior em conhecimento ou saber à burocracia - quanto ao político por vocação - aquele em condições de impor sua vontade em contraposição aos partidos, às organizações econômicas, às entidades de classe e demais agrupamentos políticos, todos condenados aos males da própria burocratização”.
} 
o conhecimento técnico e organizacional dos burocratas constitui um sinal imprescindível de seu caráter e, por extensão, de sua alta potencialidade de poder. Ao tratar de assuntos públicos baseados na superioridade decorrente do saber gerencial, eles tendem tanto a uma reserva confidencial quanto a uma maior flexibilidade no manuseio dos instrumentos de política econômica. Isto não apenas os leva a ampliar gradativamente os limites de sua jurisdição administrativa, como ainda diminui a possibilidade de que suas atividades sejam controladas externamente por meio de instituições, instrumentos e prática de ação política - enfim, uma tendência lógica quando, no âmbito de organizações privadas e públicas, estão em jogo múltiplos interesses do poder.

Diante disso, a vitória nas eleições ou em votações no Parlamento podem não ter efeito algum se não houver um controle efetivo sobre a implementação da política sobre a qual se deliberou, de maneira que se "não se consegue tal controle, a burocracia usurpa o processo de decisão política de acordo com sua tendência fundamental de transformar todos os problemas políticos em problemas administrativos" (BENDIX, 1986, p. 338).

Isso porque, como as escolhas políticas dos representantes eleitos são feitas a partir de escolhas técnicas dos burocratas, e estes nem sempre colocam à disposição daqueles todas as informações relevantes, buscando certa autonomia para ampliarem seu poder, ocorre um "déficit de responsabilização" da burocracia ${ }^{229}$ (MELLO, 2001, p. 59).

Essas considerações permitem concluir que a tecnocracia (governo dos especialistas) se opõe à democracia, na qual o protagonista tem que ser o povo e não o técnico. Daí surge um grande paradoxo: busca-se a expansão da democracia por meio da ampla participação dos cidadãos comuns na tomada de decisões referentes à coletividade, sem que eles tenham capacidade para resolver questões complexas das modernas sociedades industriais, as quais são necessárias para o atendimento de suas demandas (BOBBIO, 1983, p. $60-61$ ).

\footnotetext{
${ }^{229}$ Mello (2001, p. 61 - 64) ainda explica que o poder dos burocratas com independência pode ser percebido com clareza no caso das agências reguladoras, para as quais muito poder foi delegado. Essa delegação objetiva imunizar a regulação de determinados setores em relação à influência política, tendo em vista a ampliação da credibilidade do governo junto ao setor privado, no que se refere a cumprimento de contratos, manutenção das regras do jogo e de não expropriação da renda dos investidores por decisões administrativas, e busca sua legitimidade nas suas próprias finalidades, apesar (e até por) de inibir a manifestação da vontade democrática por meio dos representantes eleitos. Diante disso, o autor pondera que a delegação é necessária para atender às exigências de funcionamento do Estado e às demandas da sociedade, porém ela implica "crescente déficit democrático e insuficiente responsabilização dos seus dirigentes". Desta maneira, "em última instância, o desenho institucional nas democracias contemporâneas que atribui a responsabilização a um sistema de cheks and balances entre os poderes revela-se pouco capaz de gerar resultados satisfatórios e alta legitimidade".
} 
A ineficiência do controle do Parlamento sobre a burocracia decorre, principalmente, da dificuldade de acesso à informação ${ }^{230}$ e ao conhecimento técnico, pois há uma grande assimetria em favor dos burocratas ${ }^{231}$.

Os técnicos defendem que os problemas de regulação devem ser retirados da influência das disputas políticas e resolvidos segundo parâmetros científicos que permitem chegar à verdade, de maneira que estabelecem uma forma diferente de legitimação do governo $^{232}$ (ROSE; MILLER, 1992, p. 188).

Assim, os problemas são despolitizados por dois mecanismos: pela sua recolocação como problemas privados a serem resolvidos pelos indivíduos e pelo mercado; ou pela sua transformação em problemas técnicos a serem resolvidos pela aplicação de conhecimentos racionais e profissionais especializados da burocracia estatal (ROSE; MILLER, 1992, p. 197).

Porém, "do ponto de vista normativo, não se pode admitir que, em nome de uma pretensa eficiência estatal, a gestão econômica se processe fora do jogo competitivo, transparente e aberto a todas as forças políticas organizadas”. Evidentemente, certas questões econômicas, como a desvalorização da moeda, devem, em princípio, ser tratadas sigilosamente a fim de proteger interesses públicos e evitar benefícios privados, mas devem ser decididas dentro de regras democráticas e submetidas ao controle social por meio dos Poderes Legislativo e Judiciário, ou de outros meios (LOUREIRO, 1997, p. 177).

Isso porque, as decisões tomadas por técnicos sobre matérias econômicas, afastadas dos espaços decisórios democráticos e pretensamente legitimadas pela eficiência de seus resultados, na verdade, procuram esconder atrás de uma aparente neutralidade, o

\footnotetext{
${ }^{230}$ Ribeiro (2002, p. 57) afirma que toda espécie de controle, especialmente o administrativo, tem na informação um aspecto fundamental, pois o controle, no limite, consiste em "comparar as informações coletadas com modelos construídos que indicariam os objetivos desejados ou desejáveis".

${ }^{231}$ Nesse sentido, Rocha (2004, p. 68 - 69) exemplifica que "a especialização técnica e o caráter sigiloso de certos procedimentos próprios do mercado financeiro colaboram para agravar o problema do déficit democrático. Ao desempenhar suas funções, os burocratas geralmente justificam sua ação referindo-se ao interesse público, a ele associando razões técnicas de alta complexidade. Conseqüentemente, somente os iniciados em economia monetária e finanças e os protagonistas do mercado financeiro conseguem acompanhar e exercer algum tipo de controle sobre as decisões tomadas com o grau necessário de conhecimento". Cf. MELLO, 2001, p. 61 e BORSANI, 2004, 119 - 121.

${ }^{232}$ No Brasil, entre mil novecentos e noventa e cinco e dois mil e dois, procurou-se implantar a denominada “Administração Gerencial”, a qual tem como foco a eficiência e os resultados, colocando em segundo plano os procedimentos, enfoque da "Administração Burocrática". Para tanto, foram criados órgãos independentes, as "Agências", aos quais se atribui a virtude de serem formados segundos "critérios técnicos, não políticos", de maneira que poderiam atuar de forma neutra e "livres da ingerência política na sua condução", o que, todavia, não corresponde à verdade, pois as Agências não são verdadeiramente independentes. Além disso, com a referida Reforma, o cidadão passa a ser compreendido como cliente ou consumidor e ocorreu um "desmonte da estrutura do Estado, o sucateamento do Poder Público e o abandono de qualquer possibilidade de implementação de uma política deliberada de desenvolvimento nacional” (Bercovici, 2006, p. 150 - 153).
} 
fato de serem um "instrumento do status quo"233 (FARIA, 1982, p. 115 - 116; p. 154 $155)$.

Ou seja, esse tipo de racionalização e tecnificação das decisões políticas "cria condições para que a dominação burguesa se torne imune às críticas. Afinal, opor-se a uma determinada ordem racional é, por definição, um ato irracional - e, como tal, condenável” (FARIA, 1988, p. $76-77$ )

Por meio da neutralização dos controles políticos democráticos e a da "ampliação da zona cinzenta entre o administrativo e o político", "a burocracia retira do processo político-parlamentar a efetiva capacidade de decidir" ${ }^{234}$ (FARIA, 1988, p. 55 $56)$.

Como os novos papeis do Estado se concentram no Poder Executivo ${ }^{235}$, cresce a atuação da burocracia na negociação com os diferentes grupos e classes sociais e, consequentemente, dá-se o "esvaziamento político dos órgãos legislativos”. Ou seja, ocorre

\begin{abstract}
o progressivo enfraquecimento e a crescente inadequação dos mecanismos de ação, representação e fiscalização historicamente associados à democracia liberal diante do fortalecimento dos anéis burocráticos que, com o tempo, transformamse em loci institucionais na determinação dos rumos da administração, na alocação de valores, na distribuição dos excedentes etc (FARIA, 1988, p. 45) .
\end{abstract}

Esse cenário transforma a separação de poderes em mera forma com a finalidade de "geração de lealdade, organização do consenso e redução de instabilidades",

\footnotetext{
${ }^{233}$ Assim, as ações denominadas de racionais (formuladas por especialistas e justificadas tecnicamente) são muitas vezes utilizadas para justificar decisões de regimes autoritários ou decorrentes das "pressões dos setores sociais articulados sobre os 'anéis burocráticos ("anéis burocráticos" são círculos de informação do Executivo que, substituindo como loci decisórios os órgãos legislativos dos regimes democráticos e minimizando a ação política inerente às instituições representativas, convertem-se em mecanismos destinados a permitir uma articulação mais funcional e menos formal entre os múltiplos setores tanto do Estado como da própria sociedade) (FARIA, 1988, p. 72 - 73).

${ }^{234}$ Nesse sentido, Bonavides $(2004$, p. 346 - 347) afirma que a ascensão dos técnicos guarda íntima correspondência com o declínio do prestígio dos Parlamentos, pois os tecnocratas, sob uma aparente neutralidade técnica e científica tentam trazer para si a responsabilidade da tomada de decisões políticas, procurando restringir as atribuições do Parlamento.Isso porque, "o tecnocrata é o burocrata falsamente politizado, à testa do poder. Não combate com a palavra, mas com o cálculo ou a estatística. Tendo a frieza lógica do matemático, não lhe apraz a crítica, o debate, o tumulto da tribuna, mas a submissão, o silêncio, a anuência. O desenvolvimento do País afigura-se-lhe uma operação aritmética, jamais um problema de implicações humanas e sociais".

${ }^{235}$ Faria $(1988$, p. 72$)$ afirma que a valorização da racionalidade material promovida pelo Estado intervencionista "esvazia as mediações parlamentares tradicionais e retira dos órgãos legislativos o monopólio da produção jurídica". E acrescenta que há uma "tendência do Executivo de ignorar a práxis partidária, dirigindo-se diretamente à opinião pública, com o objetivo de organizar o consentimento e criar padrões mínimos de legitimidade mediante campanhas de divulgação de seus valores, valendo-se da informação como meio de doutrinação e embotamento crítico".
} 
enquanto as decisões políticas são de fato tomadas a partir da negociação de interesses travada entre as classes dominantes e os seguimentos tecnocráticos sem que os mecanismos forjados para impedir a concentração e desempenhar o controle do poder consigam operar a contento. Diante disso, “o Estado intervencionista acaba sendo operado como um instrumento de criação e reprodução das condições favoráveis à manutenção e à expansão do modo capitalista de produção" ${ }^{, 236}$ (FARIA, 1988, p. 57).

Diante desses fatos, o primeiro passo para ampliar as possibilidades de atuação do Parlamento no controle democrático da tecnocracia é reconhecer que as decisões por ela tomadas são falsamente despolitizadas, ou seja, permanecem políticas, mas são levadas para arenas decisórias imunes ao controle democrático ${ }^{237}$.

É preciso reconhecer que as decisões técnicas são "expressões de pontos de vista de atores políticos como quaisquer outros", devendo ser rejeitada a sua neutralidade. Assim, "o conhecimento técnico-científico deve almejar o desenvolvimento da qualidade das decisões políticas e não tentar substituí-las” (LOUREIRO, 1997, p. 177).

Portanto, as decisões dos tecnocratas, inclusive em matéria econômica, devem ser tratadas como políticas e submetidas aos mecanismos de controle democrático.

Além disso, diante da pluralidade de soluções exigidas pelos problemas administrativos, o conhecimento dos diferentes atores sociais passa a ser fundamental para a gestão, não podendo o processo decisório ficar restrito à burocracia (SANTOS, 2002, p. 48).

Assim sendo, o Parlamento deve continuar a atuar na contenção da ameaça tecnocrática e desenvolver mecanismos amplos de fiscalização e controle da atividade executiva, os quais não podem ficar limitados às comissões de inquérito, pedidos de informações e convocações de autoridades para prestar informações às comissões permanentes. Entretanto, a grande dificuldade para exercer este papel reside na informação da qual dispõe para atuar, e que se revela insuficiente. Esse acesso às informações é

\footnotetext{
236 Verificam-se "desequilíbrios no modelo ocidental/liberal de Administração Pública”, pois com a fragmentação da Administração, esta passa a ser fortemente influenciada pela instância econômica, ao mesmo tempo em que ganha autonomia e deixa de se subordinar ao poder político, ocorrendo, ainda, uma perda do poder hierárquico das instâncias superiores devido ao fortalecimento das inferiores. Além disso, fica comprometida a separação entre instâncias diferentes, como a econômica e a administrativa (estatização da economia e controle do poder econômico sobre a Administração), a administrativa e a política (politização da Administração e tencnificação da política), bem como entre os diferentes níveis hierárquicos da Administração Pública (SUORDEM, 1995, p. 75 - 82).

${ }^{237}$ Nesse sentido, Faria (1988, p. 57 - 58) afirma que "tecnificação" da política "não elimina a práxis política - apenas a desloca para novas formas e instâncias de intermediação de interesses que, exigindo do Estado a expansão de seus quadros burocráticos e de suas funções regulatórias, envolve grupos organizados mediante a institucionalização de sistemas de representação baseados em negociações diretas, ao nível dos setores sociais mais organizados, e no controle coercitivo, ao nível dos setores sociais menos ágeis e influentes.
} 
especialmente precário nas matérias econômicas e financeiras. Ao não ter domínio sobre essas informações, o Legislativo será "um poder com vocação para museu", ou seja, “estará marginalizado da correnteza social, inteiramente isolado, frouxo de ação e perspectiva, carente de atualidade e influência. Como um poder deposto, terá serventia apenas para legitimar, formalizar e registrar em figura de lei os atos do poder. Tal acontece nas ditaduras $^{238, "}$ (BONAVIDES, 2004, p. 348 - 349).

Por isso, o desafio que se coloca é como garantir o acesso do Parlamento a todos os conhecimentos e a todas as informações técnicas de que necessita para efetuar seu controle democrático, bem como tornar o debate sobre as questões tidas como eminentemente técnicas permeável ao debate público, porque sozinho não será capaz de controlar a tecnocracia.

\subsection{Controle Político do Executivo sobre o Parlamento.}

Nesta dissertação, defende-se que o Legislativo, mesmo no Presidencialismo brasileiro, por ser o Poder mais representativo da diversidade dos interesses, das idéias e dos próprios conflitos presentes na sociedade, bem como, pelo fato de ser o mais permeável ao controle popular, deve exercer o controle do poder político mediante: o estabelecimento de diretrizes gerais e metas a serem cumpridas pelo Executivo na concretização dos direitos econômicos e sociais; a fiscalização do cumprimento das orientações que estabeleceu; e a responsabilização das autoridades no caso de serem injustificadamente desobedecidas.

Entretanto, pesquisas demonstram que o Governo é quem exerce o controle político sobre o Parlamento. É verdade que em algumas situações há resistências, porém, como se discutirá no próximo capítulo, essa resistência, na maioria das vezes, é fruto da defesa de interesses privados ou eleitorais, e não da intenção de se dar um direcionamento diferente daquele indicado pelo Governo na busca da concretização dos direitos econômicos e sociais.

Algumas avaliações sobre a atuação do Congresso Nacional costumam apontar, contraditoriamente, que constitui um obstáculo institucional ao efetivo exercício do

\footnotetext{
${ }^{238}$ Weber comenta que "la situación de um Parlamento cuyo rol estaba limitado a rechazar propuestas financeiras o legislativas del gobierno o a presentar peticiones en favor de los gobernados correspondía a um constitucionalismo aparente e no permitía participar positivamente em las tareas de gobierno", sendo diferente a situação quando "el gobierno tenía que ser directamente elegido por los miembros de aquél o precisaba el apoyo de una mayoría para mantenerse em funciones, ya que de ello se seguía la responsabilidad del gobierno ante el Parlamento em cuanto a la dirección y aprobación de los asuntos políticos. Entonces podía decirse que existía um verdadero gobierno parlamentario" (BEETHAN, 1979, p. 97 - 101).
} 
governo e, por outro lado, que simplesmente chancela as iniciativas do Executivo, sem reflexão mais profunda, numa atitude meramente formal. Quanto ao primeiro aspecto, aponta-se que: a Constituição Federal de 1988 tornou o Brasil ingovernável, pois o quadro institucional forjado por ela e pela legislação eleitoral, semelhantes ao sistema criado $\mathrm{m}$ 1946, baseado no presidencialismo e no multipartidarismo, acarretaria um sistema político "em que um presidente impotente e fraco se contraporia a um Legislativo povoado por uma miríade de partidos carentes de disciplina”; a separação dos poderes, característica do sistema presidencialista, incentivaria um comportamento irresponsável dos parlamentares, pois lhes seria mais interessante do ponto de vista político-eleitoral a não cooperação com o Executivo. 239

No entanto, existem importantes diferenças em relação ao sistema de $1946^{240}$, pois os poderes legislativos do Presidente foram bastante ampliados e há uma forte concentração de poderes nas mãos dos líderes partidários, de maneira que os trabalhos legislativos se estruturam a partir dos partidos e não dos parlamentares. Além disso, estudos empíricos de Figueiredo e Limongi (1998, p. 81 - 83; 2003, p.62), realizados entre a promulgação da Constituição de 1988 e os mandatos do governo de Fernando Henrique Cardoso, revelaram alto grau de disciplina partidária e de colaboração do Legislativo com o Executivo, que não foi nem conflituoso (impedindo a ação do governo e a implementação de sua agenda), nem subserviente (simplesmente fazendo toda a vontade do Executivo).

A Constituição Federal de 1988 fortaleceu o Congresso Nacional, recuperando poderes que perdera no decorrer do regime autoritário militar ${ }^{241}$, porém manteve muitos

${ }^{239}$ Cf. FIGUEIREDO e LIMONGI, 2003, p. 62, 1998, p. $81-83$.

${ }^{240}$ Abranches (1992, p. 163 - 165; 177 - 178) assinala que a Constituição Federal de 1946 apresentava "uma mescla de representação proporcional, com eleições disputadas em distritos com áreas gigantescas e listas partidárias abertas", o que foi "fatal para candidatos e partidos". Isso porque, "em primeiro lugar, o tamanho dos distritos eleitorais, coincidentes com as divisas dos estados, diluía qualquer elo representativo que pudesse surgir entre os representantes eleitos e seus constituintes". Além disso, o sistema de lista aberta de votação fez com que os partidos buscassem o maior número de candidaturas, compondo uma lista "de nomes conhecidos quase que exclusivamente pelos interesses locais ou corporativistas que eles pretendem representar". Por fim, a possibilidade de coligações entre partidos para as eleições proporcionais sem qualquer compatibilidade ideológica ou programática também contribuiu para a perda de identidade dos partidos. Muitos dos pontos da Constituição de 1946 foram repetidos pela Constituição de 1988, como a não exigência de fidelidade partidária e de cláusula de exclusão do Congresso de partidos sem peso eleitoral, e a possibilidade de coligações para as eleições proporcionais e a contribuindo-se com a fragilidade e a falta de clareza na diferenciação programática dos partidos políticos.

${ }^{241}$ O Poder Legislativo foi fortalecido pela Constituição, entre outros fatores, pelos seguintes: capacidade de influenciar a formulação das políticas públicas por meio de sua participação na elaboração do Orçamento do Estado, pois os projetos das leis orçamentárias enviados pelo Executivo para apreciação do Legislativo são mais abrangentes e detalhados do que o eram durante o período militar; cresceram as possibilidades de apresentação de emendas ao Orçamento pelos parlamentares, e a fiscalização de sua execução é mais rigorosa, sobretudo por meio do Tribunal de Contas; necessidade de maioria absoluta, e não mais de dois 
dos poderes de que foi dotado o Executivo ao longo do mesmo período. Consequentemente, os poderes legislativos de que dispõe o Presidente da República permitem que o Executivo comande o processo legislativo, impedindo o fortalecimento do Parlamento e acarretando a "atrofia do próprio Legislativo e a predominância do Executivo, principal legislador de jure e de fato" (FIGUEIREDO; LIMONGI, 2001, p. 41 $-42)$.

Entretanto, quatro fatores determinam o domínio do Governo sobre o Parlamento no Presidencialismo brasileiro: seu efetivo controle sobre o orçamento (assunto da próxima parte deste capítulo); as medidas provisórias; seu poder de agenda; e a "patronagem".

Quanto às medidas provisórias, salienta-se, inicialmente, que a competência conferida ao Presidente da República para adotá-las em muito se assemelha ao poder que lhe era conferido para editar decretos-lei ${ }^{242}$ durante o regime militar, pois, embora apresentem diferenças importantes, a sua previsão revela certa continuidade ${ }^{243}$ (LIMONGI; FIQUEIREDO, 2001, p. 44).

O processo de tramitação das Medidas Provisórias se divide em duas fases: a de admissibilidade e a de conteúdo. "No primeiro momento, o Congresso deliberaria sobre a constitucionalidade da matéria enviada pelo Presidente, isto é, sua adequação aos critérios constitucionais de relevância e urgência”. No segundo momento, seria apreciado seu mérito. Porém, na prática, o Congresso deixou exclusivamente ao Executivo a prerrogativa

terços, para a derrubada do veto presidencial, o qual também não mais pode incidir sobre palavras isoladas; capacidade de o Congresso Nacional "sustar os atos normativos do Poder Executivo que exorbitem do poder regulamentar ou dos limites de delegação legislativa" (Constituição Federal, artigo 49, inciso V); modernização institucional dotando as Comissões Permanentes, em casos pré-determinados, de poder para aprovar projetos de lei em caráter definitivo, evitando-se a centralização dos trabalhos no plenário e objetivando tornar o processo legislativo mais rápido e eficiente.

${ }^{242}$ Os decretos-leis apresentavam as seguintes características: podiam ser editados em casos de "urgência ou relevante interesse público"; entravam em vigor na data de sua publicação, tendo o Congresso Nacional o prazo de sessenta dias para apreciá-lo, ao final do qual seriam considerados aprovados no caso de não serem votados; não se admitiam emendas e a sua rejeição não invalidava os efeitos que produzisse durante a sua vigência

${ }^{243}$ Já as Medidas Provisórias, apresentam as seguintes: podem ser editadas pelo Presidente da República nas hipóteses previstas no artigo 62 da Constituição Federal, têm força de lei e devem ser apreciadas pelo Congresso Nacional no prazo de trinta dias; a não manifestação do Congresso Nacional no prazo estipulado implica a perda de efeitos da medida e o trancamento da pauta da Casa Legislativa em que se encontrar até que seja votada; o Congresso pode emendar as Medidas adotadas pelo Presidente; quando rejeitadas, cabe ao Congresso regulamentar as relações decorrentes de sua aplicação antes da rejeição ou declarar nulo seus efeitos desde sua edição. A favor da existência das Medidas Provisórias se argumentou que se identificam com a modernidade e com a eficiência governamentais, pois para o Estado desempenhar suas funções é necessário um processo decisório "ágil e rápido, livre de obstáculos", de maneira que o governo não fique paralisado a espera de uma decisão do Parlamento. Contrariamente, argumenta-se que essa atuação normativa do Executivo sem a concorrência do Legislativo atenta contra o princípio da separação de poderes. Portanto, elas deveriam servir para que o Executivo legislasse em situações de urgência, mas sem fazer uso abusivo desse recurso (LIMONGI e FIQUEIREDO, 2001, p. 125 - 131). 
de analisar a urgência e a relevância das matérias que seriam objetos de Medidas Provisórias, e cada vez mais, o Presidente da República passou a fazer uso dessa prerrogativa $^{244}$ (LIMONGI; FIQUEIREDO, 2001, p. 127 - 141).

As Medidas Provisórias costumam tratar, principalmente, de questões econômicas, constituindo o "modo por excelência da regulamentação econômica do governo", sendo, boa parte delas, relacionada com os planos de estabilização econômica (FIGUEIREDO; LIMONGI, 2001, p. 145 - 147) o que revela o ineficiente controle do Parlamento sobre a ação do Estado na economia.

Entretanto, os parlamentares têm um interesse especial na maneira como as Medidas Provisórias são utilizadas: muitas delas são extremamente impopulares, já que almejam ganhos generalizados e incertos para o futuro, mas implicam perdas certas no presente, de maneira que lhes interessa não aparecerem como seus autores imediatos. Diante disso, o Congresso não se colocou como empecilho para a adoção de certas políticas pelos Governos, porém, como consequência, viu reduzida sua capacidade de influenciar as políticas públicas ${ }^{245}$ (FIGUEIREDO; LIMONGI, 2001, p. 155).

Além disso, a delegação de poderes do Legislativo para o Executivo, especialmente por meio das Medidas Provisórias, pode ser explicada pelos interesses da "maioria em perseguir políticas particularistas e de curto prazo, deixando as políticas gerais e de longo prazo a cargo do primeiro" (FIGUEIREDO; LIMONGI; VALENTE, 1999, p. 55), quando deveria acontecer o contrário.

Há mais um aspecto a ser ponderado quando ao alto grau de aprovação das Medidas Provisórias: ao analisá-las, o Congresso não opta entre uma situação vigente e outra que seria produzida caso a Medida fosse aprovada, como se dá com os projetos de lei, mas sim, entre uma situação anterior e outra que já está vigorando e produzindo efeitos; assim, é mais difícil para os parlamentares rejeitarem uma Medida Provisória do que um Projeto de Lei apresentado pelo Presidente da República (LIMONGI; FIGUEIREDO, 1998, p.88 - 89).

\footnotetext{
${ }^{244}$ Esse fato é comprovado pela pesquisa de Figueiredo e Limongi (2001, p. 144), a qual aponta que os Governos do período compreendido entre 1988 e 1995 usaram Medidas Provisórias com muita frequiência, "tanto para assuntos de relevância e urgência, quanto para tocar o dia-a-dia do governo e da administração do Estado". Diante disso, a "reação do Congresso ao uso desse instrumento foi, em geral, dócil. Raramente questionou a admissibilidade das MPs emitidas, ou seja, não contestou o juízo do Executivo quanto à sua relevância e urgência, aprovando a grande maioria delas". Cf. FIGUEIREDO e LIMONGI, 2001, p. 144 155.

${ }^{245}$ Freitas (2009, A10) afirma que a "as medidas provisórias que jorram da Presidência da República, em outro exemplo, só são possíveis, no seu amalandrado desrespeito à Constituição, porque logo ao se instalar, o governo comprou o Legislativo, pagando com cargos públicos do Executivo”.
} 
Entretanto, destaca-se que as medidas provisórias servem muito mais para o Executivo ditar a agenda, quando tem maioria no Congresso, do que para impor medidas legislativas quando sua base de apoio é minoritária. Um fato que ilustra essa tese é que o Governo Collor, que dispunha de minoria no Congresso, utilizou menos medidas provisórias do que os Governos de Itamar Franco e Fernando Henrique Cardoso nos seus dois mandatos. $^{246}$

Passa-se, então, à discussão sobre o poder de agenda ${ }^{247}$ do Executivo.

Os fatos demonstram que, no Brasil, os Presidentes vêm obtendo alto grau de sucesso nas suas agendas legislativas. Alguns autores argumentam que isso só ocorre porque os Presidentes realizam barganhas individuais com os parlamentares caso a caso. Figueiredo e Limongi (2003a, p. 305) ponderam que esse argumento não se sustenta diante das evidências, pois as votações por eles analisadas demonstram que os partidos são disciplinados e apoiam a agenda eleitoral do Presidente, participando de um governo de coalizão.

M. Santos (1997, p. 355), todavia, pondera que

\begin{abstract}
é certo que, conforme Figueiredo e Limongi, o Executivo termina por predominar durante o processo legislativo de formulação das políticas, sendo raros os projetos de lei de iniciativa do Congresso que tratam de questões fundamentais e são aprovados com rapidez. Não é menos certo, contudo, que o Executivo não é soberano absoluto, sendo freqüentemente obrigado a submeterse a penosos processos de negociação com os partidos e líderes parlamentares da oposição, quando não com sua própria base de sustentação parlamentar ${ }^{248}$.
\end{abstract}

Esse sucesso do Executivo na aprovação de sua agenda é explicado, em parte, pelos poderes de que foi dotado pela Constituição Federal para definir a agenda de votação do Congresso. Esses poderes são: a iniciativa privativa para certas matérias; a prerrogativa do pedido de urgência para votação de suas proposituras; e as medidas provisórias. Contribui, também, a centralização da organização legislativa no colégio de líderes (FIGUEIREDO e LIMONGI, 2003a, p. 305 - 307, 1998, p.86).

\footnotetext{
${ }^{246}$ Cf. FIGUEIREDO e LIMONGI, 2003a, cit., p. 62.

${ }^{247} \mathrm{O}$ poder de agenda consiste na capacidade de determinar o que será votado, quando isso ocorrerá e em que ordem, e é capaz de influenciar o resultado final das votações (BORSANI, 2004, p. 110).

${ }^{248}$ A diferença dos resultados das pesquisas desenvolvidas pelos citados autores, segundo M. Santos (1997, p. 360) se deve à diferença dos métodos utilizados, pois essa utilizou estudos de casos de políticas de grande importância para a agenda governamental e com o método indutivo, enquanto Figueiredo e Limongi trabalharam com dados agregados e o método hipotético-dedutivo. Por meio do primeiro método foi possível "desvendar as relações conflituosas entre os dois poderes" apesar da alta aprovação e da maior rapidez na tramitação dos projetos de iniciativa do Executivo.
} 
A prerrogativa conferida ao Presidente da República de solicitar a urgência para a tramitação dos projetos de lei de sua iniciativa confere ao Executivo a capacidade de ditar a pauta do Legislativo ${ }^{249}$ (FIGUEIREDO; LIMONGI, 2001, p. 44).

O instrumento do pedido de urgência precisa ser questionado, pois seu uso pelo Executivo não se limita aos casos em que realmente há urgência, ou seja, em que o tempo de tramitação normal dos projetos pode acarretar prejuízos, mas também (e principalmente) para ditar a pauta do Parlamento, fazendo com que perca consideravelmente sua autonomia decisória na condução do processo legislativo.

O Presidente da República tem iniciativa privativa para iniciar o processo legislativo sobre diversas matérias, como orçamentárias e tributárias (FIGUEIREDO; LIMONGI, 2001, p. 44 - 45), ${ }^{250}$ todas de grande relevância para a definição das políticas públicas, especialmente na área econômica.

Porém, os poderes legislativos e de agenda do Executivo não garantem ao Presidente a capacidade de governar contra a vontade da maioria no Legislativo, constituindo-se um instrumento de barganha entre o governo e sua maioria parlamentar, e de proteção da maioria que apoia o governo contra as motivações individuais dos parlamentares na perseguição de interesses imediatos e particularistas (FIGUEIREDO e LIMONGI, 2003a, p. 64,81). Assim sendo, é necessário o apoio político dos parlamentares e, especialmente, dos partidos, para que o controle da agenda legislativa se transforme em controle da produção legislativa (aprovação das matérias colocadas em pauta).

Portanto, não obstante a combinação entre multipartidarismo e presidencialismo, bem como o personalismo decorrente do voto proporcional em lista aberta, há um controle do Executivo e dos partidos sobre o processo legislativo e o comportamento dos deputados devido a uma combinação entre patronagem e poder de agenda do Executivo. Ou seja, além do poder parlamentar, os parlamentares desejam ter acesso "aos cargos governamentais que alocam recursos públicos e regulam as atividades

\footnotetext{
${ }^{249}$ Durante o regime militar, a não manifestação do Congresso no prazo estipulado implicava a aprovação do projeto. Sob a Carta de 1988 ocorre que se "a Câmara dos Deputados e o Senado Federal não se manifestarem, sucessivamente, em até quarenta e cinco dias sobre a proposição, será esta incluída na ordem do dia, sobrestando-se a deliberação quanto aos demais assuntos, para que se ultime a votação" (Constituição Federal, artigo 64, Parágrafo Segundo). Não há uma continuidade absoluta em relação ao que era previsto na Constituição anterior, mas, de qualquer forma, "não há como obstruir a tramitação das matérias consideradas importantes pelo presidente, que tem assim a capacidade de ditar unilateralmente a agenda de trabalhos legislativos" (FIGUEIREDO; LIMONGI, 2001, p. 44, 67 - 68).

${ }^{250}$ Outras matérias cuja competência privativa é do Poder Executivo são as seguintes: criações de cargos e funções nas empresas públicas e na administração pública e autárquica; remuneração e provimento de cargos de servidores públicos; criação, estruturação e provimento de cargos e serviços públicos; criação, estruturação e atribuições de ministérios e órgãos da administração pública. E fixação e modificação de efetivos das Forças Armadas.
} 
dos agentes econômicos e sociais", pois são fundamentais para garantir votos, do que decorre a importância de se obter tais espaços no Executivo, os quais são barganhados com apoio nas votações no Parlamento. Portanto, a decisão de um parlamentar apoiar o governo não depende somente de sua concordância com o programa apresentado, mas do acesso a cargos públicos (patronagem) ${ }^{251}$. Entretanto, com o passar do tempo do governo, a influência da patronagem atual diminui, passando a ter maior peso a potencial, ou seja, a expectativa de ocupação de espaços no governo futuro. Além disso, a negociação de espaços políticos com parlamentares de oposição para garantir maiorias pode gerar descontentamentos na própria base do governo. Assim, a patronagem supre a falta de coerência ideológica decorrente do voto personalizado, porém não é suficiente, sendo completada com o já discutido poder de agenda (SANTOS, F. 1997, p. 469 - 473).

O controle da agenda (e da produção) legislativa pelo Chefe do Poder Executivo é facilitado quando ele comanda um partido disciplinado que detém a maioria das cadeiras do Parlamento. No entanto, como esse fato é raro na história, ele tem que recorrer à formação de governos de coalizão ${ }^{252}$. Alguns autores afirmam que esse tipo de

${ }^{251}$ Madson (1979, p. 130) observa que a efetiva separação de poderes, ainda que não integral, requer que cada um dos poderes tenha "vontade própria", o que se é possível se os membros de um poder tiverem a mínima ou nenhuma influência na nomeação dos membros de outros, o que requer que somente o povo seja o responsável pela nomeação para as "supremas magistraturas" nos três poderes, sendo necessária alguma flexibilização com relação ao Judiciário. Villa (2009, A3) afirma que a "desmoralização da atividade parlamentar chegou a tal ponto que o político comunica por meio da imprensa quais os cargos que deseja para apoiar o governo: a partilha da máquina pública é realizada abertamente". Em seguida, ressalta que "na verdade, a ampla maioria do Congresso Nacional não deseja nenhuma mudança de fundo. Querem e vivem do saque organizado do Estado, que, no Brasil, recebeu a curiosa denominação de presidencialismo de coalizão. Como se a aliança estabelecida entre o Executivo federal e sua base no Congresso tivesse algum princípio político".

${ }^{252}$ Abranches $(1988$, p. 20 - 21) afirma que a freqüência de coalizões ao longo da história republicana brasileira "reflete a fragmentação partidário-eleitoral, por sua vez ancorada nas diferenciações sócioculturais". E acrescenta: "é nas sociedades mais divididas e mais conflitivas que a governabilidade e a estabilidade institucional requerem a formação de alianças e maior capacidade de negociação". Os problemas institucionais enfrentados pelo Brasil até o processo de redemocratização que culminou n Assembléia Constituinte de 1987 e 1988, segundo o autor, não decorre do sistema de representação e da fragmentação partidária, mas da "incapacidade de nossas elites em compatibilizar nosso formato institucional com o perfil heterogêneo, plural, diferenciado e desigual de nossa ordem social", pois "as regras de representação e o sistema partidário expressam essa pluralidade; não a podem regular, simplificando-a ou homogeneizando aquilo que é estruturalmente heterogêneo". A formação das coalizões de governo se inicia com a aliança eleitoral, quando ocorrem negociações em torno de diretrizes programáticas, "usualmente amplas e pouco específicas" e de diretrizes para formação do governo em caso de vitória eleitoral; em seguida ocorre a constituição do governo, quando há uma grande disputa por "cargos e compromissos relativos a um programa mínimo de governo, ainda bastante genérico"; e, por fim, há a "transformação da aliança em coalizão efetivamente governante", quando surge o problema da "agenda real de políticas, positiva e substantiva e das condições de sua implementação" (ABRANCHES, 1988, p. 27 - 28). Segundo Abranches (1988, p. 29 - 30), "o maior risco ao desempenho da coalizão está no quadro institucional do Estado para decidir, negociar e implementar políticas", pois diante do potencial de conflitos decorrente da heterogeneidade dos partidos que formam a aliança eleitoral e de sustentação do governo, as questões mais controvertidas são deixadas para serem resolvidas em um momento posterior, sobrecarregando-se a "pauta de decisões" e colocando em risco 
governo não é viável no sistema presidencialista, porém os estudos de Figueiredo e Limongi (1998, p.89 - 90, 100 - 101) revelam o contrário, ou seja, que é possível um governo de coalizão dentro de um sistema presidencialista multipartidário ${ }^{253}$.

Em pesquisa de Figueiredo e Limongi (2001, p. 52), no período compreendido entre 1989 e 1998, demonstrou-se que "os partidos se comportam como atores coletivos e que o conflito na Câmara se estrutura em linhas partidárias". E acrescentam: "os partidos são coesos, e as bancadas votam de acordo coma indicação dos líderes de seus partidos". 254

Isso é possível porque, apesar de os partidos políticos brasileiros serem incapazes de "estruturar e canalizar as preferências do eleitorado e de constituir raízes sólidas e profundas na sociedade civil", bem como existirem muitos incentivos da legislação eleitoral ao individualismo, os regimentos internos das Casas Legislativas consagram um sistema decisório centralizado em que o que importa são os partidos, o que favorece a disciplina partidária (LIMONGI; FIGUEIREDO, 1998, p. 91).

Portanto, a avaliação da forma de funcionamento do sistema político não pode se restringir à análise do sistema partidário e das regras eleitorais, devendo-se considerar os poderes normativos conferidos ao Presidente da República e a maneira como se estruturam os trabalhos legislativos. Nesse sentido, observa-se a existência de uma relação de interdependência entre a preponderância legislativa do Executivo, o padrão
centralizado de trabalhos legislativos e a disciplina partidária. O Executivo
domina o processo legislativo porque tem o poder de agenda e esta agenda é
processada e votada por um Poder Legislativo organizado de forma altamente
centralizada em torno de regras que distribuem direitos parlamentares de acordo

a estabilidade da coalizão. Por isso, "governos de coalizão requerem procedimentos mais ou menos institucionalizados para solucionar disputas interpartidárias internas à coalizão".

${ }^{253}$ Por exemplo, a maioria dos projetos apresentados pelos presidentes no período analisado por Figueiredo e Limongi (Governos Collor, Itamar Franco e os dois mandatos de Fernando Henrique Cardoso) só foi aprovada porque contou com o apoio dos partidos da coalizão que participava dos governos. O que demonstra que "o processo de construção de coalizões no sistema presidencialista brasileiro não difere grandemente da maneira como os primeiros-ministros agem sob sistemas parlamentaristas" (FIGUEIREDO; LIMONGI, 2003a, p. 74 - 75). Fernando Henrique Cardoso, por exemplo, obteve alto grau de sucesso aprovação de sua agenda legislativa, embora fosse extensa, complexa e em muitos aspectos impopular, pois envolvia emendas constitucionais e tinha a estabilidade monetária como prioridade máxima, enquanto a questão da desigualdade social não era contemplada, do que resultava uma dissociação entre a agenda do governo e a agenda pública. Isso foi possível porque se constituiu um "governo de coalizão de centro direita", por meio da ampliação da base de apoio parlamentar com a participação dos partidos da aliança eleitoral e outros incorporados após as eleições (dentro do espectro ideológico de centro direita) na composição do governo, os quais ocupavam ministérios e geriam importantes parcelas do orçamento da União (FIGUEIREDO; LIMONGI; VALENTE, 1999, p. 50).

${ }^{254}$ Para o conhecimento de dados estatísticos e históricos, bem como de mais detalhes que demonstram a tese descrita no parágrafo, ver as p. 102 - 123 da obra citada. Cf. FIGUEIREDO e LIMONGI, 2003a, cit., p. 78 79. 
com princípios partidários. No interior deste quadro institucional, o presidente conta com os meios para induzir os parlamentares à cooperação. Da mesma forma, parlamentares não encontram arcabouço institucional próprio para perseguir interesses particularistas. Ao contrário, a melhor estratégia para a obtenção de recursos visando retornos eleitorais é votar disciplinadamente (LIMONGI; FIGUEIREDO, 1998, p. $84-85)^{255}$

Isso demonstra que o presidencialismo e o sistema multipartidário não são empecilhos para o desempenho do governo. Assim, mudanças nas regras eleitorais e de sistema de governo, diminuição do número de partidos políticos e ampliação dos poderes dos líderes partidários não são necessários para se assegurar a governabilidade ${ }^{256}$. Pelo contrário, trarão prejuízos para a democracia, pois poderão bloquear a entrada de demandas sociais no sistema político e a limitar ainda mais a participação do Congresso na definição da agenda do governo e sua capacidade de atuar como um contrapeso de poder e instrumento de controle das ações do Executivo. ${ }^{257}$

Na formação do governo de coalizão, o Presidente procura formar sua maioria parlamentar mediante a distribuição de Ministérios e de outros benefícios políticos para os partidos, como influência sobre a Administração, cargos, nomeações de parentes de parlamentares, direção de departamentos, empresas públicas e autarquias, prestígio e controle sobre recursos do orçamento, esperando, em troca, os votos de que necessita para a aprovação de sua agenda. Os que se comprometem a apoiá-lo e não o fazem são punidos com a perda dos benefícios concedidos.

Como o Poder Legislativo apresenta pequena autonomia na formulação das políticas públicas, aumenta a importância da participação na coalizão de governo para os parlamentares, pois só assim conseguem atender às necessidades imediatas de seus redutos eleitorais e garantir seus votos nas próximas eleições. Portanto, o controle dos cargos pelo Chefe do Poder Executivo lhe "fornece mecanismos que permitem a cobrança de disciplina, pois parlamentares podem incorrer em custos a seus interesses imediatos" (com o posicionamento impopular em uma votação, por exemplo), “em função dos ganhos que

\footnotetext{
${ }^{255}$ Cf. FIGUEIREDO, LIMONGI, e VALENTE, 1999, p. 60.

${ }^{256}$ Governabilidade pode ser entendida, em sentido restrito, como "a capacidade de fazer valer a agenda legislativa do Executivo". Ela já é favorecida por um modelo institucional construído pelos constituintes e parlamentares caracterizado pela "forte concentração de poder nas mãos do Presidente da República e dos líderes partidários no Congresso" (FIGUEIREDO; LIMONGI; VALENTE, 1999, p. 49).

${ }^{257}$ Cf. FIGUEIREDO e LIMONGI, 2003b, p. 306 e 2003a, p. 82 e FIGUEIREDO, LIMONGI, e VALENTE, 1999, cit., p. 61.
} 
podem auferir como membros da coalizão de governo" (LIMONGI; FIGUEIREDO, 1998, p.101-102).

Pode haver instabilidade nos governos de coalizão quando parlamentares que já receberam seus benefícios (como a nomeação de um correligionário para um posto importante em seu curral eleitoral) ameaçam não votar segundo a diretriz do governo, caso não recebam mais benefícios. No entanto, essas ameaças só intimidam o Executivo se houver uma possibilidade real de lhe acarretar dano, o que não se dá quando se trata de uma atitude isolada ou de um pequeno grupo incapaz de lhe infringir uma derrota em determinada votação estratégica. Portanto, os parlamentares têm força para barganha com o Executivo somente quando se organizam em grupos articulados, o que é possível por meio dos partidos políticos. Assim sendo, as barganhas entre o Executivo e o Legislativo no âmbito Federal se dão em torno dos partidos, pois agir de maneira indisciplinada isoladamente representa alto risco para os parlamentares (LIMONGI; FIGUEIREDO, 1998, p. 97 - 99).

Além disso, a possibilidade de a rejeição, ou a protelação, da aprovação de um projeto de iniciativa do Executivo levar à sua paralisação pode acarretar prejuízos eleitorais para os próprios parlamentares, o que gera uma pressão política para que sejam aprovados (FIGUEIREDO; LIMONGI, 2001, p. 52).

Figueiredo e Limongi (2001, p. 72) concluem que

\begin{abstract}
o Poder Legislativo não se constitui num obstáculo à ação governamental do Executivo. Essa possibilidade foi e vem sendo removida pelos próprios parlamentares. Por certo, isso não quer dizer que o Poder Legislativo não apresente problemas, ou que venha desempenhando a contento suas funções. Ao contrário, é escassa a sua contribuição efetiva para o processo governativo.
\end{abstract}

A preponderância do Executivo sobre o Legislativo fica clara quando se constata que este Poder costuma demorar três vezes mais para aprovar projetos por ele mesmo apresentados do que os do Executivo ${ }^{258}$ (FIGUEIREDO; LIMONGI, 2001, p. 42).

O modelo institucional que centraliza o processo decisório por meio da concentração de poderes nas mãos do Presidente da República e dos líderes partidários "restringe os direitos dos parlamentares, funcionando como um freio no processamento de

\footnotetext{
${ }^{258}$ Isso se explica (além do poder de agenda do Executivo) pelo grande número de projetos apresentados individualmente por parlamentares, o que demanda um prévio e demorado processo de seleção antes de serem votados. Já os projetos oriundos do Executivo e do Judiciário já chegam ao Congresso selecionados, preparados e muitas vezes negociados. Quando chegam ao plenário, é pequeno o número de projetos rejeitados, porém, entre esses, é maior o número de projetos de iniciativa de parlamentares (FIGUEIREDO; LIMONGI, 2001, p. 42). Números precisos e tabelas referentes ao período de 1989 a 1994 podem ser encontrados na obra citada. No mesmo sentido, ver Amorim Neto e Santos (2002, p. 92).
} 
demandas que, por meio do sistema de representação vigente, são de fato canalizadas para o interior do Congresso Nacional". Esse padrão decisório consolidado no governo do Presidente Fernando Henrique Cardoso apresenta efeitos negativos para o Congresso, pois reduz sua influência direta na formulação de políticas públicas, sobretudo na área econômica. Com isso,

\begin{abstract}
o Congresso deixou de ser o lócus decisório e de debates, dando lugar a negociações entre líderes governistas e ministros e técnicos da alta burocracia governamental. Com isto, perdeu capacidade deliberativa, estreitando o espaço de debate público, reduzindo a visibilidade das decisões políticas e o acesso dos cidadãos a informações sobre políticas públicas. Em consequiência, verifica-se uma diminuição na capacidade do Congresso, enquanto contrapeso institucional e mecanismo de controle das ações do Estado, com efeitos sobre a própria possibilidade de controle vertical por parte dos cidadãos (FIGUEIREDO,
\end{abstract} LIMONGI e VALENTE, 1999, p. 51 - 52).

Nesse sentido, F. Santos (1997, p. 486) salienta que o aumento das prerrogativas do Executivo no processo legislativo (poder de agenda) "não define a intensidade das preferências, a verdadeira responsável pela paralisia decisória. Apenas retira do Legislativo a capacidade de contribuir de forma efetiva para a montagem e solução da agenda política brasileira".

Aliás, como bem sintetiza Lamounier (2007, p. A3), a situação vigente do Executivo perante o Legislativo no Brasil é a seguinte: "para quebrar a espinha do Poder Legislativo, ele conta com as medidas provisórias; para desvitalizá-lo, com o Orçamento autorizativo; para humilhá-lo, com aquele "milhozinho" distribuído por meio das emendas parlamentares individuais"

Apesar disso, durante o governo de Fernando Henrique Cardoso, o Congresso atuou na formulação de políticas sociais, garantindo e ampliando direitos de cidadania, como meio ambiente, consumidor e acesso à justiça. Além disso, embora não tenha exercido eficazmente seu papel de fiscalização, "estabeleceu e aperfeiçoou um sistema de

\footnotetext{
${ }^{259}$ Nessa linha, Maia (2006, p. A3) aponta que a busca exacerbada pelo controle da agenda legislativa pode desencadear um quadro que define como de "contraconstitucionalidade" (conceito cunhado por Natálio Botana, significa uma "tendência do Poder Executivo querer ter a hegemonia sobre o Legislativo"). Isso acontece quando: antigos adversários são cooptados; partidos políticos são constantemente debilitados; tentase impor "o exercício da democracia baseado em maiorias dominantes e não em maiorias limitadas", por meio da atração de partidos que procuram "proteção e recompensas", pelo Poder Executivo hegemônico, constituindo-se uma maioria que não atua dentro das margens do pluralismo político, mas tende a dividir os partidos, incorporando no seio de seu movimento parcelas dos mesmos para se transformar em maioria dominante; não se reconhece o adversário em sua diversidade, riqueza e capacidade para exercer alternativamente o poder.
} 
normas e procedimentos regulamentando a ação civil pública e a defesa de direitos coletivos que possibilita o aumento do controle descentralizado de grupos e movimentos sociais e dos cidadãos sobre as ações do Estado" ${ }^{\text {260 }}$ (FIGUEIREDO; LIMONGI; VALENTE, 1999, p. 52).

O problema maior, portanto, encontra-se na precariedade do controle parlamentar sobre o governo da economia.

Nesse sentido, pesquisa empírica realizada por Amorim Neto e Santos (2002, p. 108) constatou-se que

a legislação própria do Congresso não implica a mudança do status quo em termos de política econômica, tributária e de distribuição de renda; vale dizer, a agenda do Legislativo não tem a característica de um programa amplo de políticas públicas, mas, sim, a de intervenção em questões tópicas pertinentes à vida cotidiana do cidadão comum.

Diante da redução da capacidade legislativa do Parlamento, seus membros buscaram desenvolver outras atividades além da legislativa ${ }^{261}$, em especial o clientelismo, o qual se manifesta de maneira mais forte entre os que têm acesso mais fácil aos recursos estatais e, de maneira mais fraca, entre os que não integram o círculo de poder e se dedicam à oposição ${ }^{262}$ (AMORIM NETO e SANTOS, 2002, p. 110).

Ressalta-se, todavia, que apesar de o controle do Parlamento sobre o Executivo ser deficiente, porque raramente o Governo não possui o apoio da maioria parlamentar e,

\footnotetext{
${ }^{260}$ Pesquisa empírica demonstra que a área predominante nas leis de iniciativa de parlamentares é a social, ao que se segue, em patamares bastante inferiores, os temas econômicos e políticos. Constatou-se, ainda, que a produção legislativa apresenta abrangência majoritariamente nacional e não paroquial. Tais leis não são voltadas para uma localidade especifica (redutos eleitorais), mas beneficia os cidadãos genericamente. Portanto, "o esperado paroquialismo dos políticos brasileiros não se manifesta em sua produção de leis" (AMORIM NETO e SANTOS, 2002, p. 104), mas sim por meio das emendas orçamentárias individuais. Parlamentares operam sua política paroquial por meio de decretos legislativos destinados a aprovar a exploração de serviços de televisão e radiodifusão mediante concessões que precisam ser renovadas periodicamente (AMORIM NETO e SANTOS, 2002, p. 119 - 128).

${ }^{261}$ Além disso, Amorim Neto e Santos ( 2002, p. 136) salientam que a "escassa participação na formulação de políticas" torna o Congresso pouco atrativos para os políticos que se destacam, os quais procuram disputa eleições para o Executivo.

262 Amorim Neto e Santos (2002, p. 92) ressaltam que "em decorrência disso, o subconjunto de políticos socializados sob a influência da patronagem e de fracas instituições legislativas tendeu, sob o novo regime democrático, a resistir ao fortalecimento do Legislativo por temer o aumento da pressão por maior accountability e perda de espaço para a prática do clientelismo". E acrescentam (2002, p. 136): "Tal ironia aponta claramente o caráter "encarcerado" da dinâmica do Legislativo brasileiro. Este não aumenta sua capacidade de intervenção nas políticas nacionais por conta de incentivos de carreira que têm deputados e senadores, tornando-se o Executivo o principal locus de formulação da agenda legislativa do país. Ao mesmo tempo, os incentivos de carreira não se alteram no sentido de aumentar a atração exercida pelo Congresso junto a políticos mais experientes, exatamente como decorrência da baixa influência destes no processo decisório. Incentivos de carreira e amesquinhamento institucional interagem, criando obstáculos para a superação da relativamente baixa participação dos congressistas na redação das leis de nosso país".
} 
quando isso acontece, ele dispõe de mecanismos para obtê-la, há minorias que se articulam e formam um bloco de oposição, ao qual cabe a formulação de alternativas políticas e a provocação da ação fiscalizadora do Parlamento, destacando-se, para a operação desse controle, o princípio do pluralismo político, inscrito entre os fundamentos da República, na Constituição de 1988, e a liberdade de imprensa. Além disso, ocorre a fiscalização dos atos do Governo pela própria maioria, tendo em vista o temor de seus membros não se reelegerem se houver irregularidades e eles nada fizerem (CLÈVE, 1993, p. 145 - 146).

Como o Parlamento é um canal de acesso das demandas dos diferentes setores da sociedade ao sistema político, desempenha um papel importante na formulação das políticas públicas sociais, por meio da aprovação da legislação social que garante e expande direitos universais dos cidadãos e pode atuar para diminuir a dissociação entre a agenda pública e a agenda do governo (FIGUEIREDO; LIMONGI, 2003a, p. 82 - 83). Reformas devem ocorrer para fortalecer essas possibilidades e não para facilitar a governabilidade que, como se demonstrou, tem todas as condições institucionais para existir.

Conclui-se que o Parlamento se submete politicamente ao Poder Executivo em virtude da "patronagem" e do poder de agenda deste último, abdicando de sua função legislativa, sobretudo em matéria econômica, e de sua missão institucional de exercer o controle do poder político. Esse comportamento pode ser explicado pela já mencionada cultura patrimonialista e por ser eleitoralmente interessante para os parlamentares. Assim, a realização do controle democrático do poder político pelo Parlamento só é possível se essa instituição se submeter ao controle democrático da população, tanto sob o ponto de vista da legitimidade do exercício dessa função, como no da eficiência, pois, em caso contrário, predominam os interesses egoísticos a motivarem sua omissão.

\subsection{O Parlamento e a Definição do Orçamento Público.}

Na raiz do surgimento do Parlamento se encontram as funções de autorizar o rei a cobrar tributos e a realizar gastos públicos, o que se denomina de "poder financeiro". Se, naquela época, já se atribuía tanto destaque às referidas funções, com o intuito de proteger o direito de propriedade dos cidadãos, atualmente, decidir sobre cobrança de tributos e realização de gastos públicos tem uma importância maior ainda, porém com uma finalidade diversa: a tributação e o orçamento são os principais instrumentos do Estado para a concretização dos direitos econômicos e sociais. 
Assim sendo, a discussão sobre a capacidade de o Parlamento controlar democraticamente o poder político, com o intuito de direcionar as ações do Estado para a concretização dos direitos econômicos e sociais, tem como ponto fundamental a questão do orçamento público ${ }^{263}$.

A propósito, Weber (1999, p. 560) afirma que o meio de poder fundamental do Parlamento é o controle sobre o orçamento e a tributação.

O poder financeiro do Parlamento é exercido, em primeiro lugar, por meio da exigência de sua autorização para a cobrança de tributos e para a realização de gastos públicos. Em segundo lugar, pela tomada das contas dos que usam o patrimônio público em geral. Para a realização da última tarefa, no Brasil, o Congresso Nacional conta com o auxílio do Tribunal de Contas da União, o qual realiza auditorias financeiras e orçamentárias, bem como "julga as contas dos administradores e responsáveis por bens e valores públicos”. Ressalva-se que, apesar de ser vinculado ao Legislativo, o Tribunal de Contas e seus membros ${ }^{264}$ gozam de garantias e de independência e sofrem impedimentos semelhantes aos do Judiciário (FERREIRA FILHO, 2003. p. 158 - 159).

Além disso, dentro dos limites fixados pela Constituição, o Parlamento pode elaborar emendas ao orçamento, redirecionando recursos financeiros e políticas públicas. Entretanto, há uma preponderância do Executivo na questão orçamentária, pois é ele que detém os dados e os técnicos necessários para sua elaboração e execução, ficando a atuação parlamentar mais restrita ao controle e à fiscalização financeira (CAGGIANO, 2003, p. $154-155)$.

Diante disso, Weber (1999, p. 560 - 561) já destacava que "enquanto um Parlamento somente puder apoiar os reclamos da população diante da administração negando os recursos orçamentários e recusando-se a aprovar os projetos de lei ou apresentando requerimentos irrelevantes, ficará excluído da participação positiva na direção política", de maneira que lhe restará exercer uma "política negativa"265, ou seja, enfrentará “os dirigentes da administração como um poder inimigo, recebendo deles um

\footnotetext{
${ }^{263}$ Pinheiro (2007, p. 156) aponta que "os orçamentos são voltados à realização das necessidades públicas, como instrumento de intervenção estatal no domínio econômico e social"

${ }^{264}$ São nove os membros do Tribunal de Contas da União, sendo um terço escolhido pelo Presidente da República, depois de aprovada a indicação pelo Senado Federal, e dois terços pelo Congresso Nacional. Exige-se que seus membros sejam brasileiros, com mais de trinta e cinco e menos de sessenta e cinco anos de idade, de idoneidade moral e notórios conhecimentos jurídicos, econômicos, financeiros, de administração pública ou contábeis, com pelo menos dez anos de experiência em uma dessas áreas (FERREIRA FILHO, 2003. p. 158 - 159). Cf. MORAES, 2005, p. 390 - 393.

${ }^{265}$ Em um Parlamento "impotente, limitado a uma política negativa" há um domínio exclusivo dos "instintos corporativos" (WEBER, 1999, p. 562).
} 
mínimo indispensável de informações e sendo considerado um simples estorvo". Diferente é a situação quando os "dirigentes da administração tenham que ser recrutados diretamente" entre os membros do Parlamento, ou necessitam da "confiança explícita da maioria parlamentar" para manter seus cargos, de maneira que sejam "obrigado a prestar contas de forma exaustiva e sob o controle do Parlamento ou de uma de suas comissões (responsabilidade parlamentar dos dirigentes) e a realizar a administração conforme as diretivas aprovadas pelo Parlamento (controle parlamentar da administração)”. Nessas condições, o Parlamento exerce uma "política positiva"266.

No caso brasileiro, o descrédito com a participação do Parlamento na definição do orçamento público leva Maia (2006, A2) a afirmar que "a votação da Lei do Orçamento - coluna vertebral do Legislativo - passou a ser uma espécie de 'videogame' para parlamentares, além de ocupação do noticiário. Tanto faz aprová-lo ou não, uma vez que é possível a criação de despesa por medida provisória" ${ }^{267}$. Além disso, "há uma década as contas dos presidentes e os vetos presidenciais não são votados. Ou seja, inexiste a função fiscalizadora do Legislativo, e as leis - com vetos - não se completam. Sem sua vértebra institucional básica, a democracia está amputada. E o 'Estado' funciona com dois Poderes e um terceiro, de expectadores usurpados, mas que se dizem felizes". Diante disso, o autor afirma que temos um "parlamento desossado: "Barebones", ou seja, "instituição esvaziada, que se demitiu de suas responsabilidades intransferíveis".

De maneira semelhante, Romano (2006, p. A3) salienta que, como há excessiva concentração de poderes na União, os municípios são financeiramente enfraquecidos, dependendo de deputados e senadores para receberem recursos federais, pois eles trocam seu apoio ao governo pela liberação de verbas para os Municípios. Prevalece, assim, um sistema de barganhas ditando os rumos da política nacional: parlamentares trocam seu apoio ao governo por verbas; e prefeitos trocam seu apoio nas eleições para os deputados que intercedem pela liberação das verbas. Por isso, são necessárias mudanças no relacionamento entre municípios e a União, no arranjo federativo de distribuição de receitas tributárias e no processo de liberação de recursos do orçamento federal para por fim a esse sistema de barganhas. Enquanto isso não acontecer, parlamentares "serão

\footnotetext{
266 Um "Parlamento que trabalhe é um Parlamento que, colaborando, continuamente controla a administração" (WEBER, 1999, p. 564).

267 Atualmente, domina o entendimento segundo o qual a não aprovação do Prçamento implica somente a autorização para o Executivo efetuar gastos à razão de um doze avos ao mês do orçamento enviado (LIMONGI; FIQUEIREDO, 2001, p. 45), além de que, mesmo após aprovado, trata-se de uma lei meramente autorizativa, não ficando o Executivo obrigado ao seu cumprimento, com exceção da aplicação dos percentuais mínimos em saúde e educação constitucionalmente estabelecidos.
} 
levados ou assumirão alegremente o papel de meros estafetas que repassam impostos às cidades, mas exigem tarifas" 268 .

Uma idéia importante para enfrentar essa limitação do Parlamento no exercício de seu poder financeiro é o reconhecimento que as leis orçamentárias têm caráter impositivo e, não meramente autorizativo.

Nesse sentido, Pinheiro (2007, p. 68) afirma que

o Estado deve prever medidas financeiras para executar a intervenção econômica e social contemplada em tais diplomas (PPA, LDO, LOA), bem como pode ser demandado a executar medidas ou a corrigir desvios com fundamento em normas contidas nas leis orçamentárias, variando a intensidade dessa eficácia positiva conforme o nível de detalhamento das ações administrativas contempladas ${ }^{269}$.

Assim sendo, as leis orçamentárias devem ser caracterizadas como "ato impositivo e não como mera autorização", pois o Administrador é obrigado a executá-las, a não ser que a inexecução se deva à impossibilidade fática (ausência de recursos) ou jurídica (incompatibilidade com o restante do orçamento), ocasião em que não se poderá impor a execução do Orçamento à Administração nem mesmo por decisão judicial (PINHEIRO, 2007, p. 112; 119; 157)

Todavia, como ressalta Pinheiro (2007, p.150),

a inexecução de determinada ação administrativa não habilita a Administração Pública a utilizar tais recursos financeiros em outra destinação, sem que antes haja autorização do Poder Legislativo, nos termos do art. 167, VI, da Constituição Federal de 1988, combinado com o artigo $8^{\circ}$, parágrafo único, da LRF, sob pena de desvio de finalidade da execução orçamentária.

A discricionariedade administrativa pode ser limitada pelas leis orçamentárias, dentro de um exercício financeiro, mediante o detalhamento das despesas a serem realizadas em virtude do "papel constitucional" a elas atribuído. Ou seja, "quando a LOA

\footnotetext{
${ }^{268}$ Santos (2002, p. 542, 546), a propósito do orçamento participativo, salienta que, "todavia, segundo alguns pensam, dada a técnica orçamentária tradicionalmente adotada no Brasil, o corpo legislativo nunca deliberou realmente sobre o orçamento de forma substancial, e o Executivo sempre teve uma ampla margem de manobra na execução do orçamento. Contudo, o sistema em vigor permitiu ao corpo Legislativo influenciar essa execução através dos métodos tradicionais, populistas e clientelistas. Os legisladores tinham seus feudos eleitorais nas diferentes regiões, e os votos que extraíam deles estavam diretamente vinculados às obras que conseguiam incluir no orçamento. Ora, este era precisamente o sistema clientelista a que o OP pretendeu pôr um ponto final, residindo aí, em grande medida, a hostilidade ou a distância com que os legisladores não ligados ao PT encararam o orçamento participativo". Em seguida, o autor ressalva que "a consolidação do OP só faz sentido político se romper com o velho sistema clientelista-patrimonialista".

${ }^{269}$ A propósito, Pinheiro (2007, p. 79) ressalta que "por força do artigo 167, I, da Constituição Federal de 1988, apenas as medidas previstas na LOA são passíveis de imposição à Administração Pública, dependendo do conteúdo delimitado por este ato administrativo".
} 
define com densidade normativa suficiente uma determinada ação administrativa, não cabe juízo discricionário da Administração Pública sobre sua conveniência e oportunidade, devendo executá-la” (PINHEIRO, 2007, p. 104 - 106).

Pode-se, então, concluir que as leis orçamentárias não "apenas autorizam a Administração Pública a executar os programas de governo", pois "não há liberdade no tocante ao juízo de realizar, ou não, as ações administrativas", o que abre a possibilidade para se exigir administrativa ou judicialmente a realização de uma ação estatal prevista nessas leis orçamentárias quando for fática e juridicamente possível, sem que ocorra interferência indevida do Judiciário na esfera da Administração ${ }^{270}$ (PINHEIRO, 2007, p. $151 ; 162)$.

Além disso, "o caráter impositivo da LOA constitui fundamento jurídico para a cominação de sanções aos agentes públicos que incorrerem em omissão ilícita, inclusive crime de responsabilidade por ofensa à lei orçamentária” (PINHEIRO, 2007, p. 180).

O reconhecimento do caráter impositivo do Orçamento Público é um passo importante, porém não suficiente para se reforçar o controle do Parlamento sobre o direcionamento dos recursos públicos. Isso porque, como se verá na apresentação das conclusões de outro estudo realizado por Figueiredo e Limongi, o Poder Executivo ${ }^{271}$ dispõe de instrumentos capazes de "estabelecer e manter suas prioridades de políticas públicas" no Orçamento e dispõe de uma "ampla margem de liberdade na fase de execução orçamentária" o que facilita a implantação de seus programas governamentais. Isso não quer dizer que o Congresso não tenha influência nas escolhas orçamentárias, porém a capacidade de controle do Executivo sobre o processo orçamentário permite que ele induza a cooperação dos parlamentares, os quais precisam atuar, partidariamente, para influir na distribuição dos recursos orçamentários e atingir seus objetivos eleitorais (FIGUEIREDO e LIMONGI, 2008, p. 13 - 14).

Os autores (2008, p. 21) apontam que há uma convergência de agendas entre o Executivo e o Legislativo, de maneira que tanto os parlamentares governistas como os da

\footnotetext{
${ }^{270}$ Portanto "é dever atribuído à Administração Pública a realização da programação contida nestas leis orçamentárias, não podendo efetuar outra que julgue mais oportuna ou conveniente ou simplesmente se omitir na realização dos créditos suplementares. A discricionariedade na alocação dos recursos públicos ocorrerá dentro dos limites deixados pelas leis orçamentárias e não se estende ao ponto de cumprir, ou não, o programado (PINHEIRO, 2007, p. 153).

271 A análise dos referidos autores abrange seis anos do Governo de Fernando Henrique Cardoso (1996 2001). Os autores (2008, p. 12) apontam as limitações na análise restrita às instituições básicas do Estado, como a forma de governo e o sistema eleitoral, para explicar a dinâmica do processo político, destacando a necessidade de estudo dos "mecanismos microinstitucionais", como as normas que regem a tramitação das leis orçamentárias, para compreendê-lo adequadamente.
} 
oposição apresentam suas emendas para os programas prioritários do governo, porém a execução das emendas beneficia os parlamentares governistas.

Ressalva-se, todavia, que esse direcionamento das emendas para os programas prioritários do governo ocorre com o intuito de ampliar as chances de serem executadas.

Os autores (2008, p. 22) salientam que "apenas as emendas individuais apresentam traços normalmente atribuídos à participação do Congresso no processo orçamentário: dispersão de recursos e participação no nível local”. Porém, como os valores destinados por meio de emendas individuais representam uma parcela pequena dos recursos orçamentários destinados a investimentos, e como geralmente se inserem nas políticas definidas pelo governo, de maneira que se limitam a especificar o local onde serão aplicadas, não se pode afirmar que gerem "distorções no gasto público global". Assim, o Legislativo funcionaria como "um canal de informação sobre demandas e/ou necessidades sociais".

A interferência do Legislativo na formulação do Orçamento Público é bastante limitada. Primeiramente, a Constituição Federal atribui exclusivamente ao Executivo a iniciativa para leis orçamentárias (Plano Plurianual, Lei de Diretrizes Orçamentárias, Orçamento Anual e leis para abertura de créditos não previstos no Orçamento aprovado). Em segundo lugar, em seu artigo 166, ela autoriza o Congresso a emendar o orçamento, porém emendas que criam despesas precisam indicar os recursos necessários para cobrilas, mediante a anulação de outras despesas, sendo vedadas anulações de dotações referentes a pessoal e encargos, serviço da dívida e transferências tributárias obrigatórias pela Constituição, e as despesas correntes pela Lei n. ${ }^{\circ}$ 4.320/64. Assim sendo, o Congresso interfere quase que exclusivamente nas despesas referentes a investimentos. Em terceiro lugar, a não aprovação do orçamento não acarreta nenhuma consequência, o que diminui o poder de barganha do Congresso. Além disso, a lei orçamentária é autorizativa e não vinculativa, de maneira que o Executivo não é obrigado a efetuar todos os gastos nela previstos. Por fim, a Lei 4.320/64 autoriza o remanejamento de despesas entre diferentes rubricas, dentro dos limites estabelecidos pela Lei Orçamentária Anual (FIGUEIREDO e LIMONGI, 2008, p. 31 - 33).

As restrições à interferência do Legislativo e do próprio Executivo na definição do orçamento não se limitam apenas a aspectos legais, mas também a decisões prévias, como as despesas que envolvem a manutenção da operação da máquina pública e os programas continuados, bem como os gastos compulsórios estabelecidos legal ou constitucionalmente (FIGUEIREDO e LIMONGI, 2008, p. 33). 
Além disso, a margem de interferência no Orçamento é limitada pela política macroeconômica do Governo e pelo fato de grande parte de seus recursos se destinarem a amortização e aos juros da dívida pública (FIGUEIREDO e LIMONGI, 2008, p. 35 - 39).

Regras internas do Congresso Nacional, como a Resolução n..$^{\circ}$ 2/95, que disciplina a tramitação das leis orçamentárias e o funcionamento da Comissão Mista de Planos, Orçamento e Fiscalização, limitam os interesses individuais dos parlamentares e estimulam sua atuação em bloco. Por exemplo, as emendas coletivas têm precedência e envolvem maior volume de recursos do que as individuais (FIGUEIREDO e LIMONGI, 2008, p. 48 - 49).

A Resolução n. ${ }^{\circ}$ 2/95- $\mathrm{CN}^{272}$ restringiu a capacidade de o Congresso alterar, significativamente, a proposta enviada pelo Executivo, pois vedou a criação de programas e sub-programas, de maneira que os parlamentares podem somente escolher as localidades em que serão aplicados os recursos dos programas definidos pelo Executivo, ou seja, "não se contempla a possibilidade de o Congresso definir prioridades e políticas próprias via a proposição de novos programas" (FIGUEIREDO e LIMONGI, 2008, p. 55).

Como mencionado, a atuação do Congresso se limita quase que exclusivamente às despesas de investimento, entretanto, "uma parcela considerável da política do governo, talvez a mais importante do ponto de vista de seu impacto social e mesmo político, é definida nas despesas de custeio" (FIGUEIREDO e LIMONGI, 2008, p. 71), como as referentes à manutenção de programas de saúde, educação e promoção social, como o "Bolsa Família".

Figueiredo e Limongi (2008, p. 75 - 76) apontam que, embora o Legislativo possa alterar quase integralmente a proposta de investimento enviada pelo Executivo, não o faz, sendo "praticamente preservada", de maneira que "as ações do Executivo e do Legislativo na área de investimentos parecem andar por trilhos paralelos". Isso porque "se quiserem ver suas emendas executadas, os parlamentares, tanto da base do governo quanto da oposição, precisam direcionar suas emendas para programas cuja prioridade é definida pelo governo".

As despesas com custeio de políticas sociais que limitam os investimentos do Estado decorrem de legislação ordinária que determina sua implementação, a qual pode ser alterada pelo Congresso Nacional no sentido de sua diminuição a fim de que existam mais recursos disponíveis para investimento. Entretanto, o Legislativo tem atuado no sentido de

\footnotetext{
${ }^{272}$ Após várias pequenas alterações foi revogada e substituída pela Resolução n. ${ }^{\circ}$ 1/2001-CN, a qual manteve ou até ampliou as referidas restrições.
} 
manutenção dos gastos sociais, o que revela uma opção política desse poder combinada com setores do Governo (FIGUEIREDO e LIMONGI, 2008, p. 86 - 92).

Figueiredo e Limongi (2008, p. 100) ressaltam que "o grau de liberdade das escolhas dos parlamentares é exíguo, impedindo que esses usem o orçamento para articular e veicular propostas políticas alternativas", de maneira que as emendas de parlamentares oposicionistas e situacionistas não apresentam grande diferença de agenda.

Os autores (2008, p. 101) também asseveram que a "apreciação congressual do orçamento é altamente centralizada e segue linhas partidárias".

Em seu estudo, os autores (2008. 102 - 104) revelam que, na execução das emendas, "o governo favorece os parlamentares de sua base em quase todas as unidades orçamentárias", entretanto parte das emendas dos parlamentares oposicionistas é executada e parte dos governistas não é.

Quanto à afirmação de que as emendas parlamentares individuais provocam dispersão de recursos e ineficiência, os autores (2001, p. 111) questionam se "existe algum critério alocativo capaz de gerar uma alocação superior à efetuada pelos parlamentares" e "por que burocratas e planejadores fariam uma alocação mais justa e eficiente", ressaltando que "os parlamentares, pelo menos, podem ser, e de fato o são, punidos pelos eleitores" 273 .

Devido às restrições de valor e à margem de mudança das emendas individuais ${ }^{274}$, ocorre que "as emendas institucionais e coletivas são muito mais importantes". Emendas institucionais são aquelas apresentadas pelos relatores e as coletivas são as das Comissões e bancadas estatuais ${ }^{275}$. Assim, o "aumento da influência do Legislativo na alocação de recursos se deu por meio de emendas que dependem de atores institucionais (relatores) e de processos decisórios coletivos (bancadas e comissões)" (FIGUEIREDO e LIMONGI, 2008, p. 113 - 116).

É por meio das emendas das comissões que o "Congresso acaba desempenhando um papel suplementar e auxiliar na definição da distribuição de recursos por ministérios" (FIGUEIREDO e LIMONGI, 2008, p. 119).

\footnotetext{
${ }^{273}$ Portanto, "não há razão para supor que a alocação feita por burocratas ou pelo Executivo seja mais eficiente ou justa do que a feita pelos parlamentares. A alocação feita por burocratas ou de forma centralizada também sofre de disfunções ou e anomalias conhecidas" (FIGUEIREDO e LIMONGI 2008, p. 130).

${ }^{274}$ Todos os parlamentares têm os mesmos direitos na apresentação de emendas individuais tanto no que se refere ao procedimento quanto ao montante de recursos disponíveis (FIGUEIREDO e LIMONGI, 2008, p. 112).

${ }^{275}$ Conjunto dos deputados federais de determinado estado da Federação.
} 
A pesquisa de Figueiredo e Limongi (2008, p. 124 - 126) permite concluir que, somente nas emendas individuais, o Congresso se manifesta de maneira localista, porém tais emendas apresentam um baixo impacto no perfil geral do orçamento.

Figueiredo e Limongi (2008, p. 137) salientam que a execução das emendas individuais "é ditada pelos objetivos de política econômica do Executivo", ou seja, seu volume depende do volume de recursos disponíveis, e dos critérios políticos, pois têm prioridade as emendas dos parlamentares que apoiam o governo.

A pesquisa demonstra, ainda, que a probabilidade de o deputado votar a favor da agenda do governo depende de sua filiação partidária, sendo que os partidos que apoiam o Governo têm mais emendas executadas. Entretanto, a pesquisa mostra que a filiação partidária "explica tanto a votação em plenário quanto a execução das emendas", de maneira que a troca de apoio à agenda do governo por execução de emendas não se daria mediante barganhas individuais, mas sim por negociações partidárias na formação do Governo de coalizão (FIGUEIREDO e LIMONGI, 2008, p. 139 - 148).

Mesmo porque, a formação da agenda do Governo seria fruto de uma barganha entre o partido do Presidente e os demais partidos que integram a coalizão de Governo e passam a formular sua agenda (portanto, os parlamentares da base não somente votariam a favor da agenda do governo, como também participariam da sua formulação) e ocupar pastas ministeriais e postos fundamentais de controle da Comissão Mista de Orçamento do Congresso Nacional, quais sejam, a presidência, a relatoria geral e as relatorias setoriais (FIGUEIREDO e LIMONGI, 2008, p. 153 - 161).

Esse estudo demonstra que o problema não está no excesso de interferência do Parlamento na definição do Orçamento Público, mas na sua falta. A participação do Parlamento não deveria ficar restrita a uma pequena parcela dos recursos disponíveis para investimentos, deveria abranger todas as linhas gerais do Orçamento. Observa-se, todavia, que, antes disso, seria necessária uma maior participação do Parlamento na definição das diretrizes da política econômica, pois se trata de um grande fator limitador da própria formulação das leis orçamentárias pelo Executivo.

Quanto ao fato de os parlamentares participarem da formulação da agenda do governo, é preciso ponderar que essa participação se restringe a uma pequena elite. Além de que, como a chance de execução das emendas dos parlamentares situacionistas ser muito maior do que a dos oposicionistas (e a execução de emendas tem um grande peso eleitoral), acaba-se induzindo a ampliação do apoio ao governo independentemente da concordância com a política que desenvolve. Além disso, o fato de existir uma lógica 
partidária no posicionamento dos parlamentares como governistas ou oposicionistas, tanto nas votações como na execução das emendas, também se explica pelo alto índice de migração partidária em direção aos partidos da base do governo, a que se costumava assistir no início de cada legislatura, antes que fosse firmado o novo entendimento segundo o qual parlamentares que mudam de partido podem perder seus mandatos.

\subsection{Judicialização da Política e Politização da Justiça.}

As limitações enfrentadas pelo Parlamento no cumprimento de seu papel institucional, sobre as quais se discutiu até agora, podem indicar a hipótese segundo a qual deve caber ao Judiciário a missão de concretizar os direitos econômicos e sociais, do que decorre o denominado fenômeno da judicialização da política e politização da justiça. Com uma discussão sobre essa hipótese se encerrará este capítulo.

Partidos políticos e sindicatos, instituições ligadas ao circuito Governo/ Parlamento, foram forjados para canalizar os conflitos sociais por meio da formulação de políticas e defesa de interesses de longo prazo e que afetam toda a sociedade.

No entanto, o contexto atual indica um esvaziamento do circuito Governo/ Parlamento, o enfraquecimento da democracia representativa e a perda de representatividade dos partidos políticos, surgindo novos atores sociais que se organizam para lutar por questões pontuais, específicas e de curtíssimo prazo, tais como as associações de moradores, os movimentos ligados a direitos reprodutivos e liberdades sexuais, organizações não governamentais ambientalistas e movimentos sociais que lutam por direitos específicos, como o acesso à universidade, à moradia e à terra (CAMPILONGO, 1998, p. 32 - 34).

Em muitas ocasiões, esses "novos atores", especialmente os que representam os "setores mais fragilizados da sociedade", não enxergam no circuito Governo/Parlamento, mas sim no Judiciário, o seu interlocutor político, ou seja, a instituição na qual buscarão a “afirmação de seus direitos" (CAMPILONGO, 1998, p. 33 - 34).

Por exemplo, diante do não atendimento do direito à educação, um partido político procuraria discutir e mobilizar a sociedade por uma ampla reforma a ser debatida no Parlamento e no Governo. Já uma associação de moradores se mobilizaria e, eventualmente, ajuizaria uma ação junto ao Judiciário ou representaria no Ministério Público para que ele o fizesse, reivindicando a construção de uma creche no bairro. 
A atual valorização do Poder Judiciário, que envolve, entre outros riscos, a transformação do cidadão em cliente dependente do Estado e a privatização da cidadania, pode ser explicada como uma

resposta à desqualificação da política e ao derruimento do homem democrático, nas novas condições acarretadas pela decadência do Welfare State, fazendo com que esse Poder e suas instituições passem a ser percebidos como a salvaguarda confiável das expectativas por igualdade e a se comportar de modo substitutivo ao Estado, aos partidos, à família, à religião, que não mais seriam capazes de continuar cumprindo as suas funções de solidarização social (VIANNA, 1999, p. $24-25)$.

No caso brasileiro, alguns fatores que contribuíram para essa perda de confiança da população menos favorecida nos partidos e nos seus representantes são as sucessivas reformas para privatizar serviços públicos e desconstitucionalizar direitos que ocorreram após o processo de redemocratização do país, levando os atingidos por essas medidas a buscar o Judiciário (FARIA, 2003, p. 1).

Portanto, e apesar de seus riscos, abre-se a possibilidade de se construir uma cidadania à margem (ou paralela) ao circuito Governo/Parlamento, com o Poder Judiciário se transformando em uma arena muito importante para a luta pela expansão da cidadania. $^{276}$

Observa-se que a conflituosidade coletiva da democracia contemporânea deságua no Poder Judiciário por enxergar nele uma alternativa ao sistema político que não vem desempenhando satisfatoriamente a sua função, o que acarreta a judicialização da política e o protagonismo dos tribunais. ${ }^{277}$

Esse fenômeno se manifesta, sobretudo, com relação ao problema da efetivação dos direitos sociais e à construção da igualdade. Discute-se a possibilidade de serem efetivados por meio de demandas judiciais, situação que se coloca na delicada fronteira entre o sistema político e o jurídico. Essa discussão, que tem sua origem na inclusão dos direitos sociais no rol dos direitos fundamentais das Constituições, apresenta três pontos polêmicos: as fronteiras entre o político e o jurídico diante da "judicialização da política"278; a legitimidade dos tribunais para atuarem nesse campo; e os limites para a

\footnotetext{
${ }^{276}$ Sobre a pressão dos movimentos sociais sobre o Judiciário ver LOPES, 1998, p. 80 - 81.

${ }^{277}$ Sobre o protagonismo dos tribunais, ver: SANTOS, et. ali., 1996, p. 13.

${ }^{278}$ Favetti (2003, p. 34) define a judicialização da política como o "fenômeno no qual há uma transferência do conflito político de sua arena própria (arena política) para uma arena jurídica". E acrescenta: "este
} 
operacionalização e efetivação de decisões judiciais referentes a essas matérias (FRISCHEISEN, 2004, p. 74 - 77).

A função política desempenhada pelo Judiciário, historicamente, consistia no controle e na legitimação (justamente pela existência do controle) dos outros órgãos do Estado. Porém, com a incorporação dos direitos sociais pelas Constituições, o Judiciário assumiu outra função política, qual seja: a efetivação de direitos sociais (LOPES, 1989, p. $136-138)$.

Nesse sentido, Campilongo (1998. p. 47) pondera que, "sem abandonar a tradicional função de adjudicação da conflituosidade inter-individual, o magistrado atua, no Estado social, como um garantidor da estabilidade e da dinâmica institucionais. Os direitos sociais agregam ao Estado de Direito um considerável aumento de complexidade". Assim sendo, no campo dos direitos sociais, o Judiciário tem o desafio de "conferir eficácia aos programas de ação do Estado, isto é, às políticas públicas”.

Frischeisen (2004, p. 78 - 79) compreende essa judicialização da política como um "desdobramento do Estado Democrático de Direito", pois nesse Estado, os Poderes Judiciário, Executivo e Legislativo se submetem às regras constitucionais, de maneira que, se direitos sociais são desrespeitados por ação ou omissão estatal, estes podem ser demandado perante o Judiciário, ao qual se conferiu a função de garanti-los.

Tais demandas, que eram veiculadas tão somente por via política, por exemplo, por meio das eleições e da atividade do Poder Legislativo, passaram a ser pleiteadas no âmbito do Poder Judiciário, o qual se tornou "verdadeira válvula de escape para o autoritarismo legislativo do Executivo Federal", a fim de coibir o desrespeito às normas constitucionais, especialmente às que garantem direitos sociais. Essa atuação, no entendimento de Frischeisen (2000, p. 101 - 103), não tem o intuito de substituir o Executivo e o Legislativo pelo Judiciário ou pelo Ministério Público, mas simplesmente de assegurar o cumprimento e a adequada interpretação da Constituição Federal e das leis, em sintonia com as demandas dos diversos setores da sociedade.

Assim sendo, a referida autora (2004, p. 83) aponta que a busca pelo Judiciário para a afirmação de direitos representa uma manifestação da autonomia dos sujeitos, os quais, muitas vezes, não conseguem se fazer ouvir pelos mecanismos representativos.

Nesse mesmo sentido, defendendo que os Tribunais são legítimos e capazes de garantir a efetividade de direitos sociais, há, por exemplo, a posição de Comparato (1997), 
que afirma que o Judiciário tem competência para julgar questões políticas, controlar a constitucionalidade de políticas públicas, especialmente quanto à efetivação de direitos sociais.

Entretanto, a atuação dos tribunais na esfera política sofre duas ordens de limitações: uma diz respeito à sua legitimidade, e outra à sua capacidade. Além das limitações, existem alguns riscos a serem considerados: tensão com os outros poderes; indiferenciação funcional; e ameaças à própria democracia.

Nesse sentido, é esclarecedora a lição de Santos (1996, p. 20):

a questão da legitimidade só se põe em regimes democráticos e diz respeito à formação da vontade da maioria por via da representação política obtida eleitoralmente. Como, na esmagadora maioria dos casos, os magistrados não são eleitos, questiona-se o conteúdo democrático do intervencionismo judiciário sempre que este interfere com o poder legislativo ou com o poder executivo. A questão da capacidade diz respeito aos recursos que os tribunais dispõem para levarem a cabo eficazmente a política judiciária. ${ }^{279}$

Um primeira observação crítica a ser feita quanto à super-valorização do Judiciário e de suas atribuições é que ele não é composto por representantes do povo, mas sim por funcionários não eleitos, os quais se sujeitam às leis e não aos eleitores, de maneira que "não participaria propriamente do poder soberano do Estado". Além disso, ressalta-se que é "um órgão do Estado, e não um órgão acima do Estado, embora possa às vezes parecer acima dos outros poderes"(LOPES, 1989, p. 124).

Diante disso, a burocracia estatal, as forças de mercado e a mídia questionam:

no âmbito da democracia, como pode almejar o direito à última palavra uma instituição que controla de modo quase total o acesso aos seus quadros e em cujo âmbito os valores da independência e da autonomia se sobrepõem a outros com os quais deveria compor, como os da eficiência, transparência e equilíbrio das finanças públicas? (FARIA, 2003, p. 1 - 2).

No entanto, ressalta-se que

se a esfera de atuação dos tribunais cresceu a ponto de levá-los a assumir funções políticas, bloqueando iniciativas do Executivo ou justapondo-se ao Legislativo, é porque a Constituição de 1988 de alguma forma o permitiu, na medida em que consagrou um extenso elenco de direitos, aumentou as garantias para proteção dos direitos fundamentais e instituiu um federalismo fiscal, por meio da

\footnotetext{
${ }^{279}$ Os referidos recursos abrangem o pessoal e de estrutura e, o problema da ausência de meios próprios para os tribunais fazerem valer suas decisões.
} 
transferência de recursos da União para estados e municípios (FARIA, 2003, p. 17).

Por outro lado, também não se pode deixar de alertar para o risco de se transformar o Judiciário em "agência de controle da vontade do soberano, permitindo-lhe invocar o justo contra a lei"280 (VIANNA, 1999, p. 21).

Como se pode observar, o problema da legitimidade política do Judiciário se relaciona à precariedade do controle democrático ao qual ele se submete.

Nesse sentido, Lopes (1998a, p.76) ensina que

a independência do Judiciário tem que ser dos outros poderes e dos interesses mais poderosos da sociedade. Sua autonomia tem que ser para aplicar a lei, e fazer valer os direitos dos cidadãos conquistados na Constituição e nas leis, e para manter a paz e a seguranças entre os iguais. Deste ponto de vista, o Judiciário tem também de ser autônomo em relação à voz das ruas, no sentido de que não pode julgar levado pela emoção.

Entretanto, continua o autor (1998a, p.76) "não pode ser independente, no sentido de irresponsável, ou não prestar contas à sociedade, aos cidadãos no que diz respeito à máquina judicial”.

Vale destacar que, ao contrário do que ocorre no Brasil, onde a "independência e a autonomia estão mais próximas do sistema do antigo regime de patrimonialismo dos cargos, de exclusivismo corporativo até, do que de democracia propriamente dita", na Europa e nos Estados Unidos, existe um efetivo controle externo, naquela por meio de órgãos de controle administrativo e por tribunais constitucionais eleitos pelo Parlamento e com mandato fixo, e nestes diretamente pelo Poder Legislativo. ${ }^{281}$

Conclui-se, preliminarmente, que, amparado em normas Constitucionais referentes a direitos sociais previstos e mecanismos judiciais para garanti-los, o Judiciário tem legitimidade para julgar questões políticas e determinar o cumprimento desses direitos.

\footnotetext{
${ }^{280}$ Freitas (2009, A10) ressalta que "as apropriações do poder legislativo, feitas pelo TSE e pelo STF, foram revestidas pelas afirmações de magistrados de ambos, e por vários comentaristas, com este aplauso: ' $O$ Judiciário agiu para suprir a omissão do Congresso'. Os dois tribunais nada supriram, nem poderiam fazê-lo: conferiram-se um poder que a Constituição não lhes dá". Portanto, "suprir omissão do Congresso" é exercer poderes que exigem a representatividade conferida pelo voto popular, o que nem um só integrante do TSE ou do STF tem. Além disso, se esse dois tribunais podem suprir o Congresso, o Congresso também há de poder supri-los, decidindo processos que vagam por anos e anos nas altitudes inebriantes do Judiciário. Por fim, o autor (2009, A10) conclui que "os avanços do Judiciário (representados pelo STF e pelo TSE) sobre os poderes do Legislativo só são possíveis porque a degradação do Congresso e de sua função o impede de reagir".

281 Para maiores detalhes sobre este ponto ver LOPES, José Reinaldo de Lima. Crise da Norma Jurídica e Reforma do Judiciário. In: FARIA, José Eduardo (org.). Direitos Humanos, Direitos Sociais e Justiça. São Paulo: Malheiros, $1998^{a}$, p. $77-80$.
} 
Porém, isso não significa que possa assumir funções que cabem a outros sistemas sociais diferenciados ou ficar imune ao controle democrático no desempenho de suas atribuições.

Encerrada a discussão sobre a legitimidade da atuação política dos tribunais passa-se à da sua capacidade.

A proteção dos direitos sociais, por exemplo, não consiste em impedir a intervenção de outrem numa situação consolidada, mas ao contrário, requerem a criação de uma situação. Assim, pode-se indagar como garantir judicialmente o direito à educação se não há vaga na escola, tempo livre para o aluno estudar e material gratuito ou de baixo custo (LOPES, 1998b, p. 126 - 127).

Embora em determinadas circunstâncias possam ser exigidos juridicamente, os direitos sociais dependem da atuação do Executivo e do Legislativo, em regra, para terem eficácia, por terem o "caráter de generalidade e publicidade” (LOPES, 1998b, p. 129).

Assim, nota-se que, em termos de efetivação dos direitos sociais, a atuação do Judiciário apresenta três limitações importantes em relação aos demais Poderes. Primeiramente, só atua mediante provocação, não pode atuar por iniciativa própria em relação a quaisquer matérias. Em segundo lugar, pode determinar que, em virtude de inconstitucionalidade ou ilegalidade, alguma norma não seja aplicada ou alguma política não seja implementada, como por exemplo, foi provocado a agir diante de inúmeros planos econômicos, porém ele não pode apresentar uma política alternativa, nem colocar outra norma no lugar da que julgou ilegal ou inconstitucional (LOPES, 1998b, p. 134 - 135). Por fim, o Judiciário não dispõe de meios próprios para implementar suas decisões, sobretudo em matéria de políticas públicas (FARIA, 2003, p. 9).

Além disso, a efetivação de direitos sociais muitas vezes depende de variáveis internacionais, tais como a situação da economia global, financiamentos internacionais, transferência de tecnologia, etc (CASTRO, 2006, p. 57). Assim, em virtude de a jurisdição dos Tribunais se restringir ao território nacional, não há como, por exemplo, um tribunal brasileiro determinar que um organismo financeiro internacional disponibilize uma linha de crédito para financiar a construção de casas populares ou algo parecido.

Outra limitação se refere à escassez de recursos orçamentários para o cumprimento de ordens judiciais, ou sua aplicação em outras áreas que não as sociais. Diante do problema da insuficiência de determinado serviço público indaga-se: não havendo meios para atender a todos, a melhor solução é atender àquele que foi beneficiado por uma decisão judicial, ou atender primeiramente àquele que mais precisar e, em seguida, respeitar a ordem cronológica de inscrições ou solicitações do serviço? (LOPES, 
1998b, p. 131) E ainda: a quem caberá dizer quem é o mais necessitado? Ao juiz? Ao político eleito? Ao técnico, que nem sempre é tão técnico nem tão neutro? ${ }^{282}$

Ocorre, ainda, o conflito entre a chamada "eficiência administrativa e econômica”, que os últimos governos brasileiros vêm buscando, a qual, muitas vezes, implica cortes de gastos sociais, com a necessidade de ampliação dos gastos públicos a fim de se assegurar os direitos sociais (CASTRO, 2002, p. 191).

Diante disso, poderia o Poder Judiciário ser acionado para determinar que o Governo Federal diminuísse seu superávit primário a fim de ampliar os investimentos, por exemplo, na compra de medicamentos?

Frischeisen (2004, p. 86 - 87) mesmo reconhece que a implantação de direitos sociais implica questões que "são resolvidas na esfera política", como a definição de que região da cidade ou grupo será beneficiado em primeiro lugar com alguma obra ou algum serviço público. Mas em seguida pondera que o descumprimento de normas constitucionais e legais sempre poderá ser submetido à apreciação do Judiciário, devendo-se, portanto, analisar-se em cada caso a exigibilidade de implementação de direitos sociais por via judicial.

Essas considerações demonstram que não se pode esperar que basta ajuizar uma ação e esperar que os tribunais, invocando a Constituição, vão fazer, por meio de sentenças, todo o elenco de direitos sociais saltarem dos textos normativos para a realidade, transformando-se em casas populares, escolas, postos de saúde etc., simplesmente porque eles não dispõem de meios materiais para fazê-lo. O que não significa que, diante de omissões da Administração Pública, nada possa ser feito em termos jurisdicionais.

Além das limitações materiais, os tribunais apresentam limitações organizacionais e materiais para atuarem no campo político.

O Poder Judiciário atua como um prestador de serviços, atendendo às demandas que lhe são apresentadas pelos cidadãos, e como um poder político. No desempenho de sua primeira função, assim como os demais serviços públicos brasileiros, ele tem se revelado ineficiente (LOPES, 1998a, p. 3).

\footnotetext{
${ }^{282}$ É interessante o debate sobre ser positivo ou não o Estado ser obrigado por decisão judicial a fornecer certos medicamentos. Sobre esse assunto, ver as posições opostas de BARATA, Luiz Roberto Barradas. Regulamentar é o Melhor Caminho. Folha de São Paulo, São Paulo, 17 mar. 2007. Primeiro Caderno, p. A3 e (Não) e SEMER, Marcelo. Garantindo o Exercício de Direitos. Folha de São Paulo, São Paulo, 17 mar. 2007. Primeiro Caderno, p. A 3 (Sim).
} 
Além disso, o Judiciário foi concebido e tem sua estrutura constituída para resolver conflitos inter-individuais surgidos após a violação do direito positivo, mas agora é chamado a lidar com conflitos coletivos, a responder à situação de miséria do povo, desencadeados, principalmente, por movimentos sociais que representam essa população marginalizada, sem dispor de instrumentos processuais e sem estar preparado para tanto. Assim, apesar de ocorrer uma "explosão de litigiosidade, ou justamente por causa dela, eles jamais conseguem conduzir os processos a uma solução definitiva e coerente com outras ações idênticas, dentro de prazos de tempo minimamente razoáveis" (FARIA, 2003, p. $4-8)$.

Parte das dificuldades enfrentadas pelo Judiciário pode ser explicada pela insuficiência de recursos financeiros. Porém, ainda existem problemas que afetam a sua estrutura, pois é centralizada, concentrada e de difícil acesso aos cidadãos, tanto para ajuizarem suas demandas como para efetivamente participarem e influenciarem os serviços judiciais (LOPES, 1998a, p. $72-75$.

Faria (1998, p. 95) aponta que o Judiciário brasileiro se encontra perante o dilema da necessidade de superação da enorme distância existente entre os direitos sociais positivados e a realidade social brasileira, sendo que para tanto "a atividade judicial extravasa os estreitos limites do universo legal, afetando os sistemas social, político e econômico na sua totalidade".

Embora reconheça a necessidade de atuação do Judiciário na efetivação dos direitos humanos sociais, o referido autor é muito crítico a respeito de seu desempenho, apontando uma série de dificuldades a seguir abordadas.

Em primeiro lugar, Faria (1998, p. 99) destaca a hesitação do juiz diante da necessidade de escolher entre o preenchimento de sentidos e conteúdos de normas programáticas que expressam direitos sociais, ou considerá-las como não-vinculantes, apesar de serem "um dos núcleos centrais do próprio texto constitucional". Nesse sentido, com referência à diferença entre os direitos positivados e a realidade, comenta:

trata-se do fosso revelado pela crônica incapacidade dos tribunais de aplicar normas de caráter social ou de alargar seu enunciado por via de uma interpretação praeter legem, com a finalidade de fazer valer os direitos mais elementares dos cidadãos situados abaixo da linha de pobreza. 
Dessa ineficiência resulta uma crise de legitimidade do Judiciário perante a população, pois ele não consegue cumprir os papeis que se espera que ele cumpra (FARIA, 1998, p. 101).

Como aspecto positivo, o autor (1998, p. 102) destaca a atuação dos seguimentos mais jovens da magistratura na primeira instância, os quais vêm promovendo "mudanças de caráter processual, permitindo a tais movimentos (sociais) e grupos (de assessoria jurídica popular) politizar os argumentos jurídicos, provocar decisões baseadas em critérios de racionalidade material e bloquear sentenças ditadas exclusivamente com base em critérios lógico-formais".

Entretanto, predomina na magistratura a hesitação ao lidar com demandas envolvendo direitos sociais, pois os magistrados foram formados e treinados numa concepção normativista e formalista, em que deveriam lidar com conflitos inter-individuais e respeitar rigidamente o dogma da independência entre os Poderes. Além disso, não dispõem dos conhecimentos técnicos e da experiência necessários para enfrentarem as novas formas de conflitos que lhes são apresentados e para manejarem os novos institutos jurídicos. Consequentemente, o Judiciário vem se omitindo de cumprir o papel que teria, no entendimento de Faria (1998, p. 108 - 111), a obrigação constitucional de desempenhar, qual seja, a garantia dos direitos humanos sociais previstos na Constituição Federal. Diante disso, o autor aponta a necessidade de mudanças organizacionais e culturais no Judiciário.

No que se refere à cultura jurídica, destaca-se também que a brasileira é utilitarista, no sentido de que se "imagina que todas as questões se resolvem através de um sistema de trocas de benefícios comensuráveis", e individualista, ou seja, a consideração de que o "direito do indivíduo está acima do direito da comunidade, mesmo porque a comunidade propriamente dita deixou de existir, sendo substituída pelo mercado". Diante disso, Lopes (1998a, p.82) conclui:

\footnotetext{
se as demandas mudam de sentido, deixando de ser pedido de proteção da propriedade para ser pedido de acesso à propriedade, a cultura jurídica tradicional tem dificuldades crescentes para aplicar aos casos as soluções tradicionais, ou seja, a condenação a uma devolução daquilo que foi ilicitamente retirado do poder alheio.
}

Outro ponto a ser salientado é a posição social dos magistrados, os quais pertencem à classe dominante, seja por sua origem ou por sua adesão à ordem estabelecida, ocorrendo situações de crise quando algum juiz adere a uma racionalidade jurídica alternativa (LOPES, 1998a, p. 85). 
Observa-se, assim, que além das dificuldades de meios materiais para dar efetividade aos direitos sociais, existem limites decorrentes da organização do Judiciário, de normas processuais, do excesso de demandas, da própria cultura jurídica e da posição social dos magistrados.

Ressalta-se que reformas podem ser empreendidas e limites apontados podem ser superados, no entanto, embora cumpra um papel importante no que se refere à garantia dos direitos, pelas razões já expostas e pelas que ainda serão apresentadas, ver-se-á que não se pode esperar dos tribunais a solução para o esvaziamento do circuito Governo/Parlamento no enfrentamento de problemas tipicamente políticos como a concretização de direitos sociais.

A maior dificuldade de se resolver pela via judicial demandas coletivas das classes populares por políticas públicas decorre do fato de colocarem "em questão o processo global de apropriação das riquezas e dos benefícios sociais de modo geral" (LOPES, 1998b, p. 138 - 139).

A expansão da cidadania e a garantia dos direitos sociais dependem da definição de "quem deve ficar mais rico e quem deve ficar mais pobre" na sociedade brasileira, sendo que os conservadores, aplicando a justiça comutativa definiriam que tudo deveria continuar como está. Mas a justiça comutativa só pode ser aplicada "dentro da moldura maior da justiça distributiva"; portanto, é preciso fazer justiça social para que a cidadania seja expandida e os direitos humanos sociais garantidos (LOPES, 1998b, p. 140 $-141)^{283}$

No entanto, remanesce a questão de quem deve pagar a conta da expansão da cidadania e da realização dos direitos humanos sociais. A resposta de que deve ser o Estado não é esclarecedora, pois seus recursos são provenientes dos tributos pagos pela sociedade. Assim sendo, se o Estado for "incapaz de cobrar impostos que operem transferências de renda que efetivamente permitam a constituição de políticas públicas, está garantindo apenas a concentração de renda". A corrupção na esfera pública, nesse contexto, se manifesta como um "desvio de finalidade do Estado social e democrático". Portanto, é necessário impedir a corrupção e garantir que os tributos sejam cobrados dos mais ricos e os recursos com eles arrecadados transferidos para os mais pobres por meio de políticas públicas e serviços públicos (LOPES, 1998b, p.141).

${ }^{283}$ Cf. SANTOS, 1996, p. 25. 
O Judiciário não deve, pois, deixar de dar sua contribuição para a realização da democracia e da justiça distributiva, não podendo restringir sua atuação à proteção da propriedade privada. No entanto, também, se evidencia que ele "transforma-se em arena de uma luta que o transcende". Ou seja, suas decisões têm grande importância política para explicitar esses conflitos existentes na sociedade brasileira, porém, sem soluções gerais e estruturais, conforme o seguinte paradoxo apontado por Lopes (1998b, p.142 - 143):

ou legitimando uma tirania do Legislativo e do Executivo, cercados por anéis burocráticos e interesses privatísticos, impondo às classes populares a conta do desenvolvimento nacional, ou legitimando uma ditadura do Judiciário, que em nome da defesa das liberdades burguesas auxilia a reprodução das distorções sociais existentes, ou, em nome de uma atuação transformadora sem meios para agir globalmente, corre o risco de ser entendido como sinalizando o voluntarismo irracional.

Complementando, Lopes (2004, p. 159) afirma que diante do confronto entre direitos adquiridos e políticas de reforma ou de justiça social, "se cada sujeito de direitos não pode ter seus direitos sacrificados em nome do benefício coletivo, a dinâmica social conduzirá à consolidação de injustiças”, e indica como exemplo histórico mais importante a oposição dos juristas, até o final do processo abolicionista, à abolição sem a respectiva indenização.

Um ponto a ser destacado é que existem algumas espécies de conflitos, como os referentes ao direito à moradia, que precisam ser atacados de maneira global, discutindose, por exemplo, toda a lógica de ocupação do solo urbano, não sendo eficaz uma atuação individual ou abrangendo pequenos grupos (LOPES, 1989, p. 133).

No entanto, algumas decisões judiciais em matéria de direitos sociais, ainda que visem à proteção desses direitos, podem apresentar consequências negativas.

É o caso da idéia de proteção da "parte mais fraca". Interessante exemplo é o favorecimento de inquilinos nas relações de locação, o qual acaba, indiretamente, com a pequena propriedade urbana familiar (como a de aposentados que têm um pequeno imóvel para alugar a fim de complementar sua renda e não têm condições de suportar a inadimplência e derrotas judiciais), levando a sua concentração para as mãos do capital industrial-financeiro (que pode suportar a inadimplência e derrotas judiciais), de maneira que "a aparente proteção do inquilino fez-se de fato a favor da lógica da acumulação e do lucro". Portanto, "quando não se inserem os conflitos individuais na totalidade em que se acham, os resultados da análise e do julgamento podem ser bem imprevisíveis" (LOPES, 1989, p. $138-139)$. 
Outro aspecto negativo dessa judicialização dos conflitos coletivos é que ela pode levar à despolitização dos conflitos, de maneira que percam a "sua capacidade de demonstrar a relação daquele caso particular com o todo da organização social, política e econômica. Funcionariam, pois, como mecanismos de trivialização/individualização dos conflitos, impedindo justamente seus desdobramentos num quadro mais amplo”. Assim, “quando o Judiciário toma conhecimento de demandas potencialmente públicas ou politizáveis ele procede objetivamente à integração do conflito à órbita jurídica e retira-lhe o caráter político", de maneira que acaba por cumprir a função de "desarmar os conflitos", e isso faz com que sejam ordenados e banalizados (LOPES, 1989, p. 138 - 140.

Observa-se, aqui, com toda nitidez, a dimensão política do problema discutido que se encontra na raiz da expectativa que se cria quanto ao papel dos tribunais.

Ou seja, as dificuldades enfrentadas pelo Judiciário em atender às inúmeras demandas sociais brasileiras, na verdade, revelam a situação de crise em que se encontra o Estado enquanto "ordenador das condições de vida política, ou seja, enquanto garantidor das condições de sociabilidade. O que está em discussão é quem deve ficar mais rico e quem deve ficar mais pobre" (LOPES, 1998a, p. 85).

Assim, não seria suficiente um aumento dos meios disponíveis para o Judiciário continuar a fazer o que sempre fez, mas seria necessária uma reforma mais profunda para que pudesse atender a uma clientela maior e diferente, assim como diferentes casos a serem julgados a partir de uma perspectiva muitas vezes oposta à cultura jurídica tradicional acima explicitada (LOPES, 1998a, p. 87).

O Judiciário se encontra, portanto, diante de uma escolha política fundamental a ser feita em um contexto em que os direitos sociais foram constitucionalizados, criando-se uma expectativa nos marginalizados de "incorporação à cidadania", com os movimentos populares se organizando, e os não possuidores batendo nas portas dos tribunais para pedir "sua parte na riqueza social": defender o direito adquirido à riqueza apropriada por indivíduos ou grupos com base nas "normas e práticas vigentes", ou fazer justiça distributiva atendendo às demandas dos não possuidores (LOPES, 1998a, p. 88).

No entanto, é preciso indagar: mesmo com essa reforma profunda, o Judiciário seria capaz de atender a tal demanda? São os tribunais a arena mais adequada para o processamento deste tipo de conflito?

Ora, a conflituosidade social é de difícil tratamento jurídico, pois o sistema jurídico trabalha com uma lógica decisória diferente da do sistema político. Exemplo disso se encontra na obrigatoriedade de o Judiciário decidir, enquanto que na política e na 
economia há uma possibilidade de controle de agenda, ou seja, pode-se adiar a decisão ou decidir parcialmente.

Além disso, as normas jurídicas produzidas por meio das disputas no Parlamento e no Governo funcionam como amortecedores da conflituosidade. Entretanto, como os conflitos em estado bruto e não amortecidos chegam com cada vez mais frequência e complexidade ao sistema jurídico, os tribunais acabam decidindo com critérios da política, da ciência e da economia.

A dificuldade é agravada pelo fato de o Judiciário ser obrigado a trabalhar com problemas que não podem ser solucionados pelo direito processual disponível, confundindo-se, muitas vezes, as funções judiciária e administrativa e atuando com um viés mais político do que jurídico.

Ressalta-se, também, que o sistema jurídico não pode desempenhar a função nem operar com o código do sistema político, pois ambos os sistemas apresentam códigos e funções diferentes. ${ }^{284}$

Avaliando o fenômeno da politização do direito, Campilongo (2002, p. 176) apresenta a seguinte ponderação:

a politização do direito, paradoxalmente, está associada tanto à perversão das garantias jurídicas dos cidadãos - os totalitarismos sempre "politizaram" o sistema jurídico - quanto à expansão das franquias democráticas - é justamente nas democracias que a independência da magistratura e a criatividade dos juízes ganham espaços. Além disso, a politização do direito - novamente, tanto nos regimes totalitários quanto nos democráticos - está associada à crença de que o sistema jurídico pode ser o instrumento privilegiado para a consecução dos objetivos da coletividade. Como se existisse, entre a vontade geral e o direito, mais do que a mera congruência entre escolhas valorativas e pautas de conduta, e como se houvesse, por parte do sistema jurídico, efetiva capacidade de implementação de relações causais no ambiente externo ao direito, num processo decisório unívoco e que, mecanicamente, conduzisse aos resultados esperados.

Assim, "ao contrário do que se poderia imaginar, atribuir função política à decisão judicial - em termos operativos - está distante de ser a fórmula de garantir a democracia e reforçar o Estado de Direito" (CAMPILONGO, 2002, p. 177).

Após essas considerações, é preciso ainda apontar outros riscos que a atribuição ao sistema jurídico de funções, que não lhes são próprias, envolvem.

\footnotetext{
${ }^{284}$ Nesse sentido, ver alguns conceitos sobre a "Teoria dos Sistemas" em: LUHMANN, P. 274 - 304, 1969,
} p. 53 - 64, GIORGI, In: CAMPILONGO, 2000, p. 19; 175 - 195 e CAMPILONGO, 2002. 193p. 
O primeiro deles se refere a duas ordens de tensão que se estabelecem entre o Judiciário e os demais poderes: com o Legislativo ela se dá quando do controle de constitucionalidade das leis por ele emanadas ${ }^{285}$; e, com o Executivo, ela ocorre com as normas não descumpridas pela Administração, principalmente quando direitos sociais não são atendidos (FRISCHEISEN, 2004, p. 88 - 89).

Assim, provocados a se posicionarem para dar efetividade aos direitos sociais, os tribunais se viram diante de um dilema: manterem-se neutros a fim de protegerem sua independência, mas sob o risco de se tornarem "socialmente irrelevantes", ou tutelarem os direitos sociais, correndo o risco de "entrar em competição com outros poderes e de, como poder mais fraco, começar a sofrer controle externo" pelo Legislativo e pelo Executivo (SANTOS, 1996, p. 26). ${ }^{286}$ Controle que pode acarretar a perda de sua autonomia (FARIA, 2003, p. 18).

Ferraz Júnior (1994, P. 16 - 18) critica a perda de neutralidade política do juiz, pois ele é exposto à crítica pública, sobretudo dos meios de comunicação de massa, ocasionando uma "série de tensões entre sua responsabilidade e sua independência".

Outro risco dessa "desdiferenciação de papéis, competências e prerrogativas do Executivo, do Legislativo e do Judiciário" é a "tensão institucional e a assim chamada crise de governabilidade", podendo gerar "efeitos mortais tanto para a vitalidade do regime democrático como para o desenvolvimento econômico do país" (FARIA, 2003, p. 18 - 19).

Alguns aspectos de risco também envolvem questões simbólicas, morais e referentes à condução da sociedade, das instituições democráticas e da liberdade dos indivíduos.

Partindo-se de noções da psicanálise, Maus (2000, p. 184 - 185) aponta para a existência de uma "sociedade órfã" à procura de um pai. A orfandade se dá porque os indivíduos e a própria coletividade são infantilizados pela perda de consciência da interdependência das relações sociais e da incapacidade de submissão às normas sociais e, ao mesmo tempo, transformados em "meros objetos administrados", facilmente submetidos a algum mecanismo ou instituição da sociedade industrial moderna.

O crescimento do papel do Judiciário na sociedade contemporânea se manifesta, inicialmente, pela ampliação de suas funções, quais sejam: controle judicial sobre o legislador, aumento da margem de interpretação e da quantidade e espécies de

\footnotetext{
${ }^{285}$ Faria (2003, p. 15), aponta que "ao aplicar as leis a casos concretos, em outras palavras, eles (os juízes) acabam sendo seus co-autores".

${ }^{286}$ Sobre as ameaças de controle externo em virtude da atuação política Judiciário e a possibilidade de optar por não entrar em confronto com os outros Poderes, ver também FARIA, 2003, p. 10 - 12.
} 
litígios que lhes são submetidos. Todavia, também há um aspecto simbólico, pois se reconhece nos tribunais a figura de um pai, a ponto de se poder afirmar que "há uma representação da Justiça por parte da população que ganha contornos de veneração religiosa" (MAUS, 2000, p. 185).

Diante desse contexto, o Parlamento, que é o espaço por excelência do debate e do conflito, não tem condições de disputar com a "figura imperial do pai", representada pelos tribunais, o espaço de condução política da sociedade. Desta maneira, "a eliminação de discussões e procedimentos no processo de construção política do consenso, no qual podem ser encontradas normas e concepções de valores sociais, é alcançada por meio da centralização da 'consciência' social na Justiça”' (MAUS, 2000, p. 186).

Isso tudo pode acarretar uma grave ameaça à própria democracia, como explica Maus (2000, p. 187):

quando a Justiça ascende ela própria à condição de mais alta instância moral da sociedade, passa a escapar de qualquer mecanismo de controle social - controle ao qual normalmente se deve subordinar toda instituição do Estado em uma forma de organização política democrática. No domínio de uma Justiça que contrapõe um direito superior, dotado de atributos morais, ao simples direito dos outros poderes do Estado e da sociedade, é notória a regressão a valores prédemocráticos de parâmetros de integração social. ${ }^{287}$

No caso do Tribunal Constitucional Federal alemão, chegou-se ao ponto de se controlar a constitucionalidade da própria Constituição, tendo como critérios não as normas constitucionais, mas direitos supra-positivos definidos, evidentemente, pelo próprio Tribunal, de maneira que ele extrapola a sua competência constitucional. Consequentemente, "assim como o monarca absoluto de outrora, o tribunal que disponha de tal entendimento do conceito de Constituição encontra-se livre para tratar de litígios sociais como objetos cujo conteúdo já está previamente decidido na Constituição "corretamente interpretada", podendo, assim, disfarçar o seu próprio decisionismo sob o manto de uma 'ordem de valores’ submetida à Constituição” (MAUS, 2000, p. 191 - 192).

A independência dos Tribunais foi construída por meio de sua vinculação à legalidade e de sua oposição ao patriarcalismo dos príncipes. Porém, no cenário descrito, eles passaram a assumir as funções patriarcais e a negar sua vinculação à legalidade (MAUS, 2000, p. 194).

\footnotetext{
${ }^{287}$ Aqui a autora faz referência especialmente à obra de Ronald Dworkin e à inclusão da moral no direito na atividade interpretativa do juiz, o que a imuniza perante a crítica à qual ele deveria se sujeitar.
} 
Diante disso, o Parlamento se apresenta como palco dos conflitos sociais, mas não é ele que os resolve, pois o papel de censor e árbitro é atribuído aos tribunais, os quais, com fundamento em um direito supra-positivo e não-escrito, assumem a função de "sintetizar a heterogeneidade social". 288

Em última análise, o afastamento das barreiras do formalismo legal e a atuação dos tribunais como supremos reguladores da moral com base em princípios supra-positivos podem colocar em risco a própria liberdade e autonomia dos sujeitos perante os mecanismos estatais de coerção (MAUS, 2000, p. 200 - 202).

Conclui-se que a incapacidade de o sistema político desempenhar, satisfatoriamente, sua função de tomar decisões que vinculem a coletividade, notadamente a fim de expandir a cidadania e de concretizar direitos humanos, precisa ser enfrentada por meio de ajustes no próprio sistema político, e não por meio da transferência das atribuições desse sistema para o sistema jurídico, pois este apresenta outra função e outra forma de operação, de maneira que não se aperfeiçoará o funcionamento de um e se criarão dificuldades para o funcionamento de outro. Portanto, não será por meio dos tribunais que se superará a crise do circuito governo-parlamento, mas sim com reformas nessas próprias instituições (se é que tal crise, no atual contexto, possa ser superada).

\subsection{Conclusão do Capítulo.}

As discussões realizadas ao longo deste Capítulo podem ser sintetizadas nas seguintes conclusões:

1. Embora o Estado tenha passado por muitas transformações, permanece a necessidade de controlar seu poder, não só para limitá-lo contra o arbítrio, mas também para direcioná-lo para a concretização dos direitos econômicos e sociais. Porém, os mecanismos a serem utilizados para tanto não podem ser formulados a partir dos modelos de Estado e de sociedade dos séculos XVIII e XIX. Assim sendo, o princípio da separação de poderes rigidamente interpretado se encontra superado, porém a idéia de racionalização do poder que o inspirou continua viva. Portanto, o Executivo deve ser dotado dos meios necessários para atender às demandas sociais, porém deve desempenhar essa tarefa orientado por diretrizes fixadas pelo Parlamento (por sua vez submetido ao controle

\footnotetext{
${ }^{288}$ É importante chamar atenção para o risco que este afastamento da legalidade, o antipositivismo e o antiformalismo envolvem, a exemplo do que se deu com o direito nazista, no qual se desenvolveu um verdadeiro "terror judicial", no quão o "juiz-rei do povo de Adolf Hitler deve libertar-se da escravidão da literalidade do direito positivo". Acrescenta-se ainda que "uma Justiça que não precise derivar a legitimação de suas decisões das leis vigentes torna-se no mínimo dependente em face das necessidades políticas conjunturais dos aparelhos administrativos" (MAUS, 2000, p. 195 - 197), p. 195 - 197.
} 
popular), e os mecanismos necessários para seu controle devem ser aprimorados a fim de torná-los mais eficazes.

2. A própria dinâmica de funcionamento do Parlamento já apresenta limites ao cumprimento de sua missão institucional, os quais giram em torno de cinco questões básicas: ausência de domínio sobre informações e conhecimentos técnicos; dificuldade de formação de consensos; tempo do processo legislativo; centralização do processo decisório; e a característica histórico-cultural patrimonialista do Estado brasileiro. Tais limites precisam ser enfrentados por meio de mudanças institucionais que facilitem o processamento dos conflitos, descentralize o sistema decisório, de maneira que se torne mais ágil e democrático, e fortaleça os mecanismos de fiscalização pela oposição. Porém, no atual contexto, o patrimonialismo se revela como um desafio difícil de ser transposto.

3. A transferência de funções normativas do Parlamento para o Executivo, sobretudo em matéria econômica, é inevitável, diante das próprias características do processo legislativo. Além disso, representa uma necessidade para a concretização dos direitos econômicos e sociais, pois isto exige a regulação da economia. Todavia, essa função do Executivo só pode ser realizada dentro dos parâmetros constitucionais e legais fixados pelo Parlamento, sendo que, em caso de não serem respeitados, a burocracia deve se submeter ao controle tanto do Judiciário como do Parlamento, cabendo a este último a responsabilização política e a correção de rumos.

4. As decisões tomadas pela tecnocracia são falsamente despolitizadas, ou seja, permanecem políticas, mas são levadas para arenas decisórias imunes ao controle democrático. Portanto, as decisões dos tecnocratas, inclusive em matéria econômica, devem ser tratadas como políticas e submetidas aos mecanismos de controle democrático. Assim sendo, o Parlamento deve continuar a atuar na contenção da ameaça tecnocrática e desenvolver mecanismos amplos de fiscalização e controle da atividade executiva. Entretanto, o desafio que se coloca é como garantir o acesso do Parlamento a todos os conhecimentos e a todas as informações técnicas de que necessita para efetuar seu controle democrático, bem como tornar o debate sobre as questões tidas como eminentemente técnicas permeável ao debate público, porque sozinho não será capaz de controlar a tecnocracia.

5. O Parlamento se submete politicamente ao Poder Executivo em virtude da "patronagem" e do poder de agenda deste último, abdicando de sua função legislativa, sobre tudo em matéria econômica, e de sua missão institucional de exercer o controle do poder político. Esse comportamento pode ser explicado por ser eleitoralmente interessante 
para os parlamentares. Assim, a realização do controle democrático do poder político pelo Parlamento só é possível se essa instituição se submeter ao controle democrático da população, tanto sob o ponto de vista da legitimidade do exercício dessa função, como no da eficiência, pois, em caso contrário, predominarão os interesses egoísticos a motivarem sua omissão.

6. A atuação do Parlamento na definição do Orçamento Público é fundamental para o cumprimento de sua missão institucional. O reconhecimento do caráter impositivo do Orçamento Público é um passo importante, porém não suficiente para se reforçar o controle do Parlamento sobre o direcionamento dos recursos públicos. Observa-se, a esse respeito, que o problema não está no excesso de interferência do Parlamento na definição do Orçamento Público, mas na sua falta. A participação do Parlamento não deveria ficar restrita a uma pequena parcela dos recursos disponíveis para investimentos, deveria abranger todas as linhas gerais do Orçamento. Todavia, ressalta-se que, antes disso, seria necessária uma maior participação do Parlamento na definição das diretrizes da política econômica, pois se trata de um grande fator limitador da própria formulação das leis orçamentárias pelo Executivo. Quanto ao fato de os parlamentares participarem da formulação da agenda do governo, é preciso ponderar que essa participação se restringe a uma pequena elite. Além de que, como a chance de execução das emendas dos parlamentares situacionistas ser muito maior do que a dos oposicionistas (e a execução de emendas tem um grande peso eleitoral), acaba-se induzindo a ampliação do apoio ao governo independentemente da concordância com a política que desenvolve. Além disso, o fato de existir uma lógica partidária no posicionamento dos parlamentares como governistas ou oposicionistas, tanto nas votações como na execução das emendas, é explicado também pelo alto índice de migração partidária em direção aos partidos da base do governo, à qual se costumava assistir no início de cada legislatura, antes que fosse firmado o novo entendimento segundo o qual parlamentares que mudam de partido podem perder seus mandatos.

7. A incapacidade de o sistema político desempenhar satisfatoriamente sua função de tomar decisões que vinculem a coletividade, notadamente a fim de expandir a cidadania e de concretizar direitos humanos, precisa ser enfrentada por meio de ajustes no próprio sistema político, e não por meio da transferência das atribuições desse sistema para o sistema jurídico, pois este apresenta outra função e outra forma de operação, de maneira que não se aperfeiçoará o funcionamento de um e se criarão dificuldades para o 
funcionamento de outro. Portanto, não será por meio dos tribunais que se superará a crise do circuito governo-parlamento, mas sim com reformas nessas próprias instituições. 


\section{CAPÍTULO 3 - CONTROLE POPULAR SOBRE O PARLAMENTO.}

Neste Capítulo, será analisada a capacidade de a população controlar o Parlamento. Ainda que o controle por ele exercido sobre o Executivo fosse eficiente, isso de nada adiantaria diante de sua não submissão à soberania popular. Além disso, conforme já no Capítulo anterior, a própria eficiência do controle democrático do Parlamento fica comprometida se ele não estiver submetido ao controle popular.

Existem alternativas de controle direto das decisões do Estado pela população, como os instrumentos de democracia participativa e semi-direta. Todavia, tais alternativas não podem substituir, mas somente completar a representação política parlamentar nas sociedades de massa. Neste estudo, não se cuidará dos instrumentos de democracia participativa e semi-direta ${ }^{289}$, mas sim dos instrumentos de controle popular sobre o Parlamento. Para tanto, inicialmente, serão feitas algumas considerações gerais sobre o problema da representação política. Em seguida, tratar-se-á do controle popular exercido por meio do processo eleitoral. E, por último, serão abordadas algumas possibilidades de controle popular sobre o Parlamento não relacionadas com o processo eleitoral.

\subsection{Considerações Gerais sobre a Representação Política.}

Rousseau (2000, p. 39 - 71) não aceitava o caráter democrático da representação política ${ }^{290}$. De acordo com ele, o Estado só pode ser dirigido pela vontade geral, a qual coincide com a soberania e nunca pode se alienar, pois a vontade não se transmite, de maneira que só pode ser exercida pelo próprio soberano, ou seja, o poder legislativo pertence diretamente ao povo e somente ele pode fazer suas leis ${ }^{291}$. Entretanto,

\footnotetext{
${ }^{289}$ Sobre esse assunto, ver Kelsen (2000b, p. 53 - 55). Laski (1932, p. 36 - 39) não acredita que o recurso a mecanismos de participação direta como o referendo e a iniciativa popular sejam as soluções para os problemas da democracia representativa, em virtude de sua própria incapacidade operacional de responder a questões complexas que não se limitem a "sim" e "não", que exigem conhecimentos técnicos, e pelo próprio desinteresse da grande maioria da população nessas questões. Defende que a única solução possível é a "elevación del nivel moral e intelectual del electorado, considerado en su totalidad".

${ }^{290}$ Duverger (1962, p. 79 - 80) afirma que há uma tendência nos países ocidentais, estabelecida ao longo do século XIX, de denominar de democráticos os regimes em que os governantes são escolhidos mediante eleições livres e verdadeiras, o que não estava presente nem na democracia antiga nem na doutrina de Rousseau, nas quais se entendia como democráticos os regimes em que houvesse a participação direta dos cidadãos nas decisões governamentais. Quando era necessária a designação de algum magistrado, a democracia antiga se valia do método do sorteio (DUVERGER, 1962, p. 79 - 80).

${ }^{291}$ Nesse sentido, Rousseau $(2000$, p. 91 - 92) explica "não se pode representar a soberania pela mesma razão que se não pode alienar; consiste ela essencialmente na vontade geral, e a vontade não se representa; ou ela é a mesma, ou outra, e nisso não há meio termo; logo os deputados do povo não são, nem podem ser representantes seus; são comissários dele, e nada podem concluir decisivamente. É nula, nem é lei, aquela que o povo em peso não retifica. Julga-se livre o povo inglês, e muito se engana, o que é só durante a eleição
} 
o próprio autor reconhece a inviabilidade da democracia direta nestes termos: “rigorosamente nunca existiu verdadeira democracia, e nunca existirá. É contra a ordem natural que o grande número governe e seja o pequeno governado", pois "não se pode imaginar que o povo reúna-se continuamente para cuidar dos negócios públicos, e é fácil ver que não poderia estabelecer comissões para isso sem mudar a forma de administração". E conclui: "se houvesse um povo de deuses, seria governado democraticamente, mas aos homens não convém tão perfeito governo".

Portanto, a democracia que se realizou de fato nos grandes Estados modernos não foi a direta, mas a representativa ${ }^{292}$ (SARTORI, 1994, p. 225 - 228).

Não houve representação na Antiguidade. No Feudalismo, a representação política apresentava grande semelhança com seu conceito civil, correspondendo a uma relação de mandato ou delegação. Sua concepção moderna encontra sua origem em 1789, com a Revolução Francesa ${ }^{293}$ (MALBERG, 1948, p. 942 - 946).

A doutrina da representação política foi construída a partir de dois fundamentos: a inviabilidade prática ${ }^{294}$ da democracia direta nos grandes Estados ${ }^{295}$ e a crença de que os representantes eleitos são mais aptos para analisar os interesses gerais do que os próprios cidadãos ${ }^{296}$ (BOBBIO, 1990, p. 33 - 34).

Mill (1983, p. 60) define o governo representativo como aquele

dos membros do parlamento, finda a qual, hei-lo na escravidão, hei-lo nada; e como ele emprega os breves momentos de sua liberdade, merece bem que a perca".

${ }_{292}$ Nesse sentido, ver: Sartori (1994, p. 225 - 228).

293 Antes da Revolução Francesa, os representantes eram mandatários de particulares encarregados de negociar com a Coroa, sendo na verdade adversários dos interesses do Estado. Na moderna representação, passam a constituir um órgão do próprio Estado, de maneira que além de representar os interesses da nação passam a governá-la, formulando livremente sua vontade, pois o mandato imperativo fora substituído pelo livre. Desta maneira, o Parlamento se torna um corpo de representantes da nação (SARTORI, 1962, p. 20 29). Caggiano (1987, p. 15) afirma que o governo representativo encontra suas origens na "lenta evolução das instituições britânicas" e se desenvolve paralelamente ao parlamentarismo.

${ }^{294}$ Cf. CAGGIANO, 1987, p. 14 - 15 e BASTOS, 1995, p. 13.

295 Nem mesmo o avanço dos meios de comunicação, especialmente da informática, que permitem o rápido acesso às informações e o conhecimento das preferências dos cidadãos, indicam a possibilidade de decisões políticas possam ser tomadas continuamente por diretos (LAMOUNIER, 1996, p. 35).

${ }^{296}$ Nesse sentido, Montesquieu (1962, p. 37) afirma que o povo é capaz de eleger seus governantes e julgar a sua gestão, mas "não está apto para governar por si próprio". O autor ainda pondera que "Do mesmo modo que, num Estado livre, todo homem, que se considere possuir uma alma livre, deve governar-se a si mesmo, seria preciso que o conjunto do povo detivesse o poder legislativo. Mas como isso é impossível nos grandes Estados, e está sujeito a inúmeros inconvenientes nos Estados pequenos, é preciso que o povo faça, por meio de seus representantes, tudo quanto não pode fazer por si mesmo". Jefferson (1979, p. 23 - 31) entende que o povo é a fonte de toda a autoridade da nação, e que os atos praticados pelos órgãos que cria para conduzir seus interesses são atos dela mesma e obrigatórios para o povo. Diante da inconveniência de reunir o povo para exercer os poderes soberanos diretamente e de sua inaptidão para exercê-lo, é necessário "nomear órgãos especiais para declararem a vontade do Legislativo, para julgarem e executarem esses direitos". Porém, Jefferson pondera que se o povo não tem aptidão para exercer os poderes soberanos diretamente, ele a tem para "nomear a pessoa que as deva exercer", por meio da eleição dos administradores e legisladores a cada quatro anos. 
em que o povo inteiro, ou certa porção muito numerosa dele, exerce, por meio de deputados periodicamente eleitos por ele, o poder controlador externo, que em qualquer constituição tem de residir em alguma parte. $\mathrm{O}$ povo tem que possuir este poder extremo em toda a sua inteireza. Tem de ser senhor, sempre que assim lhe aprouver, de todas as operações do governo ${ }^{297}$.

Mill (1983, p. 85 - 87) adverte que, como não se pode esperar que a maioria dos representantes e governantes aja exclusivamente segundo o princípio da justiça e a busca do bem comum, as instituições do governo representativo devem ser constituídas de maneira que não permitam que prevaleçam os interesses pessoais e parciais sobre os gerais.

Segundo a moderna teoria da representação, o poder dos órgãos do Estado (a soberania) poderia ter sua origem no povo (a massa dos cidadãos), ou na coletividade da nação ${ }^{298}$ (um ser abstrato) ${ }^{299}$. A partir desta última noção, que objetivava se contrapor ao regime monárquico durante a Revolução Francesa, surgiu o governo representativo ${ }^{300}$, o qual não correspondia nem à monarquia, nem à democracia (MALBERG, 1948, p. 872 $893 ; 911-913)$.

No governo representativo, a participação dos cidadãos na gestão do Estado se limita à eleição dos representantes da nação para um período determinado e à influência

${ }^{297}$ O autor (1983, p. 61 - 75) explica que "é essencial ao governo representativo que a supremacia prática no Estado resida nos representantes do povo". Todavia, o controle da atividade do governo e sua efetiva realização são atividades muito distintas, de maneira que o corpo representativo pode ser capaz de controlar algumas sem que o seja de executá-las, ocorrendo até de a execução direta comprometer a eficácia do controle. Portanto, é preciso considerar "que espécie de atividades um corpo numeroso tem capacidade de executar convenientemente", devendo atuar diretamente só quando for capaz de fazê-lo adequadamente, cuidando que as demais sejam realizadas por outros. Por exemplo, cabe à "assembléia representativa do povo" votar os impostos e a distribuição das receitas orçamentárias, mas não propô-los, de maneira que pode consenti-los ou recusá-los. Da mesma forma, os corpos representativos não devem administrar, pois é inapto para a "ação, no sentido próprio", a qual é mais bem realizada por um indivíduo. Mas "o que um corpo faz melhor do que o indivíduo é a deliberação", pois permite "manifestações ou ponderações sobre opiniões divergentes" (MILL, 1983, p. 62 - 63). Assim, Mill (1983, p. 65) conclui que "o dever que incumbe a uma assembléia representativa com relação a assuntos de administração não consiste em decidi-los pelo próprio voto, mas em cuidas em que as pessoas encarregadas de resolvê-los sejam as mais capazes para esse fim". Mill (1983, p. 74 - 75) pondera que "o governo é negativamente defeituoso se não concentra nas mãos das autoridades poder suficiente para realizar as funções necessárias do governo; ou se não desenvolve suficientemente pelo exercício as habilidades ativas e os sentimentos sociais dos cidadãos". Já os "males e perigos negativos" do governo representativo são: a "ignorância geral e a incapacidade" do "grupo controlador", e o "perigo de ficar sob a influência de interesses que não se identifiquem com o bem-estar geral da comunidade".

${ }_{298}$ Antes disso havia a teoria da origem divina do poder dos monarcas.

${ }^{299}$ Cf. Sieyes (1973).

300 A soberania nacional não se confunde com a popular, pois a nação não é o povo e a soberania nacional não é democrática. Segundo o princípio democrático da soberania popular, os eleitores não somente elegem os representantes que formularão a vontade do Estado, mas determinam a própria vontade do Estado ao escolher os representantes, de maneira que a vontade do Estado preexiste à do representante. Já segundo a idéia de soberania nacional, são os representantes que formulam a vontade nacional, pois a nação em si não possui uma vontade, podendo manifestar-se somente pelos representantes (SARTORI, 1962, p. 21). 
que exercem sobre os eleitos que, em tese, procuram agir de acordo com as preferências dos eleitores, objetivando a reeleição (MALBERG, 1948, p. 916 - 917).

Entretanto, como os representantes eleitos não representam o povo, mas a nação ${ }^{301}$, eles não estão jurídica ou moralmente vinculados às preferências populares. Seu dever é governar o povo, ou seja, tomar as decisões que lhes pareçam mais convenientes aos interesses nacionais, de maneira que são soberanas e vinculam todos, independentemente da aprovação popular, submetendo-se somente à Constituição (MALBERG, 1948, p. 922).

A representação política difere radicalmente da representação jurídica civil, pois: o mandatário político não representa somente o colégio eleitoral que o elegeu (que seria seu mandante), mas toda a nação; ao contrário do mandato civil, o político é irrevogável pelos cidadãos durante seu período de duração; o representante não responde por sua conduta política perante seus eleitores, ao contrário do que ocorre com o mandato civil, em que o mandatário é, juridicamente, responsável perante o mandante; no mandato civil, o mandante tem mais poderes do que o mandatário e pode determinar-lhe a maneira como deve proceder no exercício de seu mandato, enquanto que o representante político é livre no exercício de suas funções (nem mesmo os compromissos assumidos em campanha vinculam juridicamente), pois tem absoluta liberdade para expressar seus votos e suas opiniões (MALBERG, 1948, p. 925 - 928). ${ }^{302}$ Portanto, a relação entre a representação política e a privada se limita à sua origem, pois os primeiros mandatários políticos estavam vinculados às instruções dos mandantes e ao valor simbólico da manutenção do termo representação, o qual é muito relevante, pois indica a finalidade do instituto que é a defesa dos interesses da coletividade representada e não dos próprios $^{303}$ (SARTORI, 1962, p. 14 $15)$.

\footnotetext{
${ }^{301}$ De acordo com essa teoria, a eleição não representa uma transmissão de poder dos eleitores para os eleitos, mas somente uma maneira de designar os membros do Parlamento. Conseqüentemente, compreende $o$ ato de eleger os representantes não como um direito individual, mas como uma função ou obrigação que os cidadãos são chamados a desempenhar, podendo a nação, por meio de seus representantes, definir livremente as condições que conferem a um indivíduo a qualidade de eleitor. Além disso, na verdade, os parlamentares não representam a vontade da nação, pois ela não tem vontade prévia, mas "cooperam para sua formação por meio de seus votos no Parlamento". Não representam os cidadãos porque são absolutamente independentes e livres no seu querer. E também não representam a nação, pois na verdade criam a vontade nacional. Portanto, o Parlamento não é o representante, mas o órgão da nação responsável pela formação de sua vontade, a qual só começa a existir a partir de sua deliberação (MALBERG, 1948, p. 930 - 931; 935; 939 - 942; 953). Sobre a ficção da representação, ver também: Kelsen (2000b, p. 48 - 49).

${ }^{302}$ Cf. SARTORI, 1962, p. 12.

${ }^{303}$ Cf. CAGGIANO, 1987, p. $16-17$.
} 
No moderno sistema representativo ${ }^{304}$, o mandato imperativo foi proibido ${ }^{305}$, de maneira que os eleitos "não estão juridicamente obrigados por quaisquer instruções de seus eleitores", o que assegura a independência dos representantes políticos ${ }^{306}$, os quais podem ser responsabilizados perante os eleitores somente mediante sua não reeleição ${ }^{307}$ (KELSEN, 2001, p. $414-416$ ).

Neste sistema, portanto, o povo "não tem qualquer interferência direta no jogo cotidiano da política", pois se manifesta somente no processo eleitoral, ocasião em que "seleciona seus representantes para, em seu lugar, assumirem o domínio da gestão dos negócios públicos, reservando-se o direito de não reelegê-los na hipótese de não ver os seus anseios e expectativas satisfeitos" (CAGGIANO, 1987, p. 19).

A representação política se desenvolveu, inicialmente, com o sufrágio restrito à elite econômica, pois sua universalização era considerada perigosa pelas classes dominantes. Ao longo do século XIX, as lutas políticas tinham como meta a universalização do sufrágio, de maneira que democracia e sufrágio universal passaram a se confundir (DUVERGER, 1962, p. 81 - 84).

\footnotetext{
${ }^{304}$ Bastos (1988b, p. 576) afirma que as características fundamentais do sistema representativo são as seguintes: "a transferência de poderes do povo para os governantes mediante eleições; a representação integral do povo por parte dos eleitos que o tenham sido por uma zona eleitoral apelas; a liberdade dos mandatários no exercício do seu mandato; a temporariedade destes".

${ }^{305} \mathrm{O}$ fim do mandato imperativo e a clara separação entre representantes e representados foram fixados já pela Constituição francesa de 1791 (BOBBIO, 1990, p. 35 - 36). De acordo com Jellinek (1970, p. 478), o fim das instruções do mandato imperativo decorreu da impossibilidade de se chegar a conclusões e deliberações adequadas, em virtude do fato de muitas decisões que o Parlamento precisa tomar não terem sido previstas pelos eleitores e de o processo de decisão parlamentar envolver concessões e compromissos. Apesar disso, o Parlamento não pode atuar de maneira totalmente dissociada da vontade do povo, pois não se manterá por muito tempo, tendo em vista institutos como as eleições periódicas e a possibilidade de dissolução do Parlamento pelo Governo (no caso do Parlamentarismo), os quais constituem meios políticos e jurídicos de garantia do caráter do Parlamento de órgão representativo da vontade do povo (JELLINEK, 1970, p. 468; 478). Cf. BASTOS, 1995, p. 15 - 19.

${ }^{306}$ Nesse sentido, em um famoso discurso, Burke (1942, p. 312 - 313) afirma que "dar una opinión es derecho de todos los hombres; la de los electores es una opinión de peso y respetable, que un representante debe siempre alegrar-se de escuchar y que debe estudiar siempre com la máxima atención. Pero instruciones imperativas, mandatos que el diputado está obligado ciega e implícitamente, a obedecer, a votar y defender, aunque sean contrarias a las convicciones más claras de su juicio y su conciencia, son cosas totalmente desconocidas en las leyes del país y surgen de uma interpretación fundamentalmente equivocada de todo El orden y temor de nuestra constitución. El Parlamento no es un congresso de embajadores que defienden interesses distintos y hostiles, interesses que cada uno de sus miembros debe sostener, como agente y abogado, contra otros agentes y abogados, sino uma asamblea deliberante de una nación, com un interes: el de La totalidad; donde deben guia no los intereses y prejuicios locales, sino el bien general que resulta de la razón general Del todo. Elegís un diputado; pero cuando Le hábeis escogido, non ES El diputado por Bristol, sino un miembro del Parlamento".

${ }^{307}$ Ferreira Filho $(1968$, p. 68) afirma que apesar de ser irresponsável perante o povo, mesmo no sistema liberal clássico, o representante não poderia desconsiderar a opinião do povo, pois dele depende sua reeleição.
} 
Feita essa apresentação sobre a teoria clássica da representação política, far-se-á agora uma breve análise sobre algumas limitações da representação política como instrumento do controle democrático do povo sobre o Parlamento ${ }^{308}$.

Um primeiro problema que aparece se refere ao fato de a representação política não possuir as características de uma verdadeira e legítima representação, ao que se respondeu que não há e nunca haverá qualquer Estado representativo e, opostamente, que as democracias liberais existentes ainda não são plenamente democráticas e precisam ser expandidas. Contrapondo-se a essas, críticas Sartori (1962, p. 10 - 11; 26; 69; 74 - 75; 139 - 140) defende a representação política concebida a partir da idéia de soberania da nação, por ser um princípio intermediário entre o absolutismo do Estado e a soberania popular, a qual, em última análise, representa a negação do Estado. O autor ressalta que os eleitos representam o povo, mas não meros comissários ou executores de sua vontade. Desta maneira, a ficção de representação da nação constitui a única fonte de autonomia de opinião para os representantes perante os vários vínculos que os submetem ao eleitorado e ao partido, sem a qual o Parlamento perde sua razão de ser. A partir dessas ponderações, o autor propõe que o Estado representativo deve buscar um equilíbrio entre o aumento e o afrouxamento do vínculo e da submissão dos mandatários em relação aos mandantes, a fim de que os representantes tenham mais autonomia, e comando e o Estado possa funcionar com prontidão, sem que os representantes escapem completamente do controle dos representados.

A esse respeito, Lamounier (1996, p. 47 - 48) defende que deve ser assegurada autonomia para os representantes, porém entende que o voto deve funcionar como um "controle intertemporal do comportamento dos agentes públicos", ou seja, deve ter uma capacidade real de influenciar suas decisões. Entretanto, como a moderna teoria democrática se assenta sobre o princípio da busca da racionalidade, a pressão popular deve ser combinada com a busca racional das melhores alternativas, de maneira que não há um “ajuste automático" entre as preferências populares e as decisões dos representantes.

Guimarães (2000, p. 10 - 12) afirma que existem três enfoques sobre o vínculo que se estabelece entre representantes e representados: uma primeira acepção de representação relaciona-a à idéia de delegação, segundo a qual os representados conferem pequena autonomia para os representantes perante as instituições em que lhes representam;

308 No desenvolvimento desta discussão, serão utilizados autores de diferentes linhas teóricas, sem a pretensão de aprofundamento de qualquer uma delas, nem de confrontá-las. O objetivo não é confrontar teorias, mas simplesmente indicar algumas limitações e as possibilidades de o sistema representativo servir como instrumento para o exercício da soberania popular. 
a segunda relaciona representação política com uma "relação de confiança", em que os representantes têm maior autonomia, mas há a presunção de que conhecem profundamente os interesses dos representados; a última liga a representação à noção de espelho, em que o "foco central da representação política recai mais diretamente sobre um ambicionado isomorfismo de características e atos entre representantes e representados". Partindo-se dessas noções, a autora conclui que para se considerar um sistema político como minimamente representativo, é necessário que exista a combinação, em proporção difícil de determinar, dos seguintes fatores:

um certo grau de controle dos representados sobre os representantes (tal como sugere a concepção de delegação); uma certa margem de autonomia (expressa na concepção de confiança); um certo grau de identidade entre representantes e representados (acepção do espelho), envolvendo características sociais comuns a ambos.

Outro limite à representação, apresentado por Morais (2004, p. 124 - 126), refere-se ao fato de a eleição não ser capaz de expressar a vontade individual de cada cidadão, pois não se pode entender que "cada cidadão teria uma opinião racional sobre cada um dos problemas que carecem de uma decisão legislativa”. Consequentemente, a representação consiste somente em um acordo momentâneo de vontades eleitorais móveis em torno de um projeto personalizado em um candidato. Diante disso, a democracia representativa se limita ao poder conferido aos cidadãos de "decidir quem serão os decisores", diante de um conjunto de opções que lhes são apresentadas.

Nesse sentido, Schumpeter (1961, p. 343) afirma que "os eleitores não decidem casos", nem, "escolhem com independência, entre a população elegível, os membros do parlamento", pois a iniciativa depende dos candidatos que se apresentam às eleições e do apoio que podem obter, de maneira que "os eleitores se limitam a aceitar essa candidatura de preferência a outras, ou a recusar-se a sufragá-la"309.

Portanto, "a democracia não significa nem pode significar que o povo realmente governa em qualquer dos sentidos tradicionais das palavras povo e govêrno. A democracia significa apenas que o povo tem oportunidade de aceitar ou recusar aquêles que o

\footnotetext{
${ }^{309}$ Schumpeter (1961, p. 327 - 328) define o método democrático como "um sistema institucional para a tomada de decisões políticas, no qual o indivíduo adquire o poder de decidir mediante uma luta competitiva pelos votos do eleitor". Na teoria clássica da democracia, o mais importante é "atribuir ao eleitorado o poder de decidir sobre assuntos políticos", sendo a escolha dos representantes um objetivo secundário. Já na definição de Schumpeter, o mais importante é a eleição dos representantes e não a tomada de decisões sobre questões políticas pelo eleitorado. Assim, cabe ao povo "formar um govêrno, ou corpo intermediário, que, por seu turno, formará o executivo nacional, ou govêrno".
} 
governarão". Além disso, o método democrático exige "a concorrência livre entre possíveis líderes pelo voto do eleitorado" (SCHUMPETER, 1961, p. 346).

Um problema mais particular da democracia brasileira (e de outros Estados democratizados recentemente), levantado por Moraes Filho (2003, p. 189 - 190), refere-se ao particularismo, ou seja, ao predomínio dos interesses privados sobre os universais nas relações políticas, mediante comportamentos que variam dos favores à corrupção, os quais se opõem ao princípio fundamental dos sistemas democráticos da distinção entre a esfera pública e a privada.

Destacamos ainda a afirmação de Arnold (1990, p. 5 - 7), segundo o qual, o principal objetivo dos parlamentares é a reeleição, de maneira que suas decisões são influenciadas intensamente por tal objetivo, ou seja, não farão nada pela realização de outros objetivos (como a implantação de sua visão do que seja uma boa política pública) que possam colocar em risco o principal, mas se posicionarão com liberdade quando a reeleição não estiver em risco. Desta maneira, o componente eleitoral pode levar os parlamentares a apoiarem tanto interesses gerais como particularísticos. O que os parlamentares fazem ao tomar decisões é calcular qual opção contribuirá mais para suas chances de eleição.

Nessa linha, Schumpeter (1961, p. 343) pondera que

o significado social da atividade parlamentar é evidentemente votar legislação e, em parte, medidas administrativas. Mas, para compreender de que maneira a política democrática serve a esse fim social, devemos partir da luta competitiva pelo poder e cargos e compreender que a função social é preenchida apenas incidentalmente, por assim dizer, da mesma maneira que a produção é incidental à obtenção do lucro.

As considerações feitas até agora sobre o processo representativo tiveram como fundamento as relações eleitorais. Porém, ele não pode ser analisado somente a partir da expectativa de que os representantes orientem suas ações segundo os interesses manifestados pelos eleitores, pois existem muitos outros fatores que influenciam a representação ${ }^{310}$. Se em alguns casos, como o dos direitos civis, a expectativa dos eleitores apresenta grande influência, em outros, como no da política externa (salvo situações extremas), ela praticamente inexiste. (CAMPILONGO, 1987, p. 52 - 55).

${ }^{310}$ Por exemplo, "externamente à estrutura decisória da representação política - há elementos que prédefinem o que pode ser considerado "demanda"(Luhmann) e - internamente aos mecanismos das instituições representativas - regras que facilitam o fluxo de umas e interrompem o de outras demandas (Claus Offe)" (CAMPILONGO, 1987, p. 62). 
De acordo com esse modelo sociológico, denominado de "modelo elementar de input de demanda", os cidadãos possuem demandas que são introduzidas no sistema representativo ("input de demandas”), as quais, após processadas, são respondidas por ele (“output"). Parte-se da premissa segundo a qual interesses e preferências claros para os eleitores geram demandas que são comunicadas de maneira eficiente pelas eleições ao se eleger um governo para respondê-las. Porém, isso não corresponde à realidade, pois, na verdade, poucos cidadãos possuem interesses que se traduzem em demandas políticas, apresentam opiniões claras, mantêm contato com os representantes e têm a consciência de que, ao votar, "estão exprimindo demandas ou escolhas políticas”. Grande parte dos cidadãos não dispõe das informações necessárias para transmitir suas demandas e, em geral, não são "particularmente interessados ou informados sobre as decisões de seus representantes"311 (CAMPILONGO, 1987, p. 56 - 57)

A teoria dos sistemas ${ }^{312}$ apresenta um modelo alternativo denominado de "input de suporte". Ele pressupõe que "o acesso ao processo decisório é pré-determinado por uma cadeia de reações advindas do ambiente que circunda o sistema político"313.

311 Entretanto, o citado autor (1987, p. 58) pondera que apesar do fato de as demandas políticas serem formuladas por "um pequeno número de agentes" e haver uma "apatia das massas", o fenômeno acima descrito "está circunscrito ao contexto de sociedades marcadas pela concentração do capital nas mãos da minoria, pela desigualdade de oportunidades sociais e políticas e pela redução do cidadão ao papel de consumidor dos "produtos políticos"”. Sobre a apatia da população, o autor saliente que se deve a existência de "um sistema político que prima pelo disfarce das questões e pela ausência de responsabilidade dos representantes para com os representados", o que "desestimula a participação popular". E acrescenta: "a apatia dos eleitores chega a ser vista como benéfica à estabilidade política, e, por isso, é discretamente estimulada pelo sistema. Além disso, as demandas das classes sócio-econômicas dotadas de maior capacidade de agregação de interesses, organização e conflito sempre são mais efetivas - o que deságua em apatia dos setores circunstancialmente privados dessa capacidade".

312 A representação política apresenta duas dimensões segundo a teoria sistêmica: "de um lado, a relação substantiva entre representantes e representados - o "input" de demanda, a satisfação de exigências, a "congruência" na representação; de outro, a identificação simbólica do processo eleitoral - o "input" de suporte, a legitimação pelo procedimento, a distância entre representantes e representados engendrando uma confiança mitológica na representação" (CAMPILONGO, 1987, p. 65).

${ }^{313}$ Esse modelo transfere "o enfoque centrado nas variáveis estruturais - regras de organização dos partidos, legislação eleitoral, grau de operacionalidade da tripartição dos poderes, elenco de direitos sociais e políticos assegurados na Constituição -, para o exame das variáveis ambientais que influenciam na definição das políticas públicas. Ou seja, o processo decisório é explicado menos pelas práticas do sistema representativo e mais pelas variáveis sócio-econômicas ou ambientais. O contexto que envolve o sistema político é composto, de um lado, pela economia, cultura, estrutura social e personalidades da sociedade, e, de outro, pelo sistema internacional. Desse meio provêm as influências que determinam as decisões políticas" (CAMPILONGO, 1987, p. 60 - 61). A análise sistêmica aponta que a realidade política é composta, de um lado, pelo governo (Poderes Legislativo, Executivo e Judiciário), que dentre suas atividades apresenta a representativa, e, de outro, por elementos que promovem a "pré-seleção das decisões políticas (ou redução da complexidade)", como os partidos políticos, a burocracia estatal, os sindicatos, e grupos de interesse, dentre outros. Essa divisão contraria o "modelo de input de demanda", pois existência de uma pré-seleção das alternativas decisórias antes de sua chegada às instituições representativas foge de suas possibilidades de análise, já que considera somente a relação estabelecida diretamente entre as demandas dos representados e as respostas dos representantes (CAMPILONGO, 1987, p. 61). 
De acordo com o modelo de "input de suporte",314, o sistema político obtém lealdade e consenso não por meio de respostas a exigências específicas, mas sim pela “recompensa 'simbólica' que o processo de constituição de representantes incorpora", havendo um "suporte difuso" de seus membros ${ }^{315}$ (CAMPILONGO, 1987, p. 64).

A teoria dos sistemas atribui funções específicas à representação política, partindo da premissa segundo a qual "a complexidade social impõe ao sistema político a institucionalização de mecanismos de transação" entre os seguimentos conflitantes ${ }^{316}$.

Domenico Fisichella, citado por Campilongo (1987, p. 75), aponta que a representação política apresenta algumas funções fungíveis (que também são exercidas por outras instituições) ${ }^{317}$ e uma infungível, que é sua característica peculiar: o controle político $^{318}$.

${ }^{314} \mathrm{O}$ termo suporte se refere a "um conjunto de atitudes afetivas e sentimentais para com elementos do sistema político". Ele se manifesta em três objetivos políticos: o da comunidade política (visa manter um "grau mínimo de coesão entre os membros do sistema"), o do regime (apoio às regras do jogo, permitindo que o procedimento (eleição política) satisfaça simbolicamente os eleitores) e o da autoridade ("apoio aos ocupantes dos postos criados pelas regras", o qual se manifesta de maneira específica pelo voto, pela reeleição e pelas pesquisas de opinião, bem como genericamente, por meio da "disposição dos membros do sistema em aceitar as autoridades como algo inevitável") (CAMPILONGO, 1987, p. 65).

${ }^{315} \mathrm{O}$ conceito de responsividade é a base das análises sistêmico-funcionalistas sobre representação. Ele é composto por quatro elementos: "policy responsiviness", referente às relações entre as preferências dos representados e a atuação política dos representantes na formação das políticas públicas; a "service responsiveness", a qual envolve os "serviços não legislativos prestados pelos eleitores à sua clientela", ou seja, "toda sorte de favores, benesses e tráfico de influência captados em benefício de indivíduos ou grupos particulares", o que se apresenta como característica comum nos Estados burocratizados; a "allocation responsivinees", consistente na alocação de recursos orçamentários para beneficiar redutos eleitorais; e a "symbolic responsiveness", a qual "implica em relações psicológicas entre o apoio conferido aos representantes e as respostas fornecidas aos representados. Manipulando atitudes diante do eleitorado, com técnicas que vão da teatralização da linguagem à indumentária passando pelo discurso ideológico e pela hipócrita invocação de valores universais, o representante obtém apoio político e votos. Em termos distintos: o representante, respondendo simbolicamente ao público, ganha um suporte difuso que lhe confere liberdade de ação legislativa e uma credibilidade a ser desfrutada no futuro" (CAMPILONGO, 1987, p. 68 - 71).

316 Campilongo (1987, p. 71 - 75) apresenta as concepções de alguns autores: - para David Apter são as seguintes: "controle central - implica na manutenção ordenada da disciplina do sistema; especificação de metas - engloba a participação na definição de prioridades políticas; e coerência institucional - redunda em revisão, reformulação e ajuste contínuos entre os subsistemas"; - Anthony Birch divide as funções da representação política em gerais e específicas: "as primeiras compreendem o controle popular, a liderança e a manutenção do sistema". Cada função geral apresenta suas funções específicas: o controle popular "engloba responsividade ('responsiveness'), prestação de contas ('accontability') e mudança pacífica ('paceful chanche')"; "liderança abraça recrutamento de líderes e responsabilidade", ou seja, a seleção dos representantes e sua responsabilização no momento eleitoral; "manutenção do sistema combina legitimação, consentimento e alívio de pressões", ou seja, respectivamente: a atribuição à eleição do papel de justificar os atos do governo; a formação do consenso por meio de debates que façam com que a população aceite as políticas adotadas, as quais nem sempre contam, em princípio com apoio popular; e a criação de mecanismos para manifestação de descontentamentos dentro da legalidade e da constitucionalidade.

${ }_{317}$ Por exemplo, "participação política, a tomada de decisões, o recrutamento de líderes, a comunicação entre governantes e governados, a articulação de interesses, o controle financeiro do Executivo" (CAMPILONGO 1987, p. 75)

${ }^{318}$ Campilongo (1987, p.75) define função de controle político como "a função estável e formalmente institucionalizada que compreende a oposição por toda a legislatura", e pondera que "a sobrecarga de funções 
Partindo deste modelo de análise, Campilongo (1987, p. 100 - 101) aponta que a representação política é afetada pela "perda de centralidade do circuito governoparlamento", decorrente do fato de a nova conflituosidade, típica do Estado regulador da economia e da sociedade fragmentada, exigir estruturas políticas "mais ágeis e menos burocratizadas". Surgem, então, centros decisórios alternativos que passam a substituir as instituições tradicionais (por exemplo, o Parlamento) na tomada de decisões políticas importantes. Isso faz com que, muitas vezes, o governo, ao invés de conduzir a sociedade representando a vontade popular, seja conduzido pela burocracia e por grupos econômicos poderosos. Além disso, como os problemas da política econômica requerem soluções conjunturais e dinâmicas, somente o Executivo tem se ocupado deles, pois o Parlamento não tem sido capaz de atuar sobre esse campo, em virtude de os programas partidários e a atuação parlamentar estarem voltados para "uma perspectiva de médio e longo prazos a respeito dos temas econômicos". Nesse contexto, a representação política deixa de desempenhar, satisfatoriamente, tanto sua função específica como as fungíveis a contento. Diante disso, movimentos sociais ${ }^{319}$ e práticas neocorporativas ${ }^{320}$ se apresentam como alternativas para canalizarem as demandas sociais.

Os movimentos sociais constroem uma nova cidadania com forte ênfase na noção de igualdade substancial e agem de forma desvinculada de intermediários ou representantes. Entretanto, a atuação dos movimentos sociais e a nova cidadania que constroem, apresentam o risco de esvaziar "espaços conquistados pela democracia representativa", devido ao seu caráter particularista, que leva à perda da dimensão do todo e "enfrenta contradições inerentes ao seu baixo nível de institucionalização" 321 , as quais só podem ser superadas por "formas institucionais capazes de unificar as demandas políticas: os partidos, as eleições e os parlamentares. Conclusão: é necessária alguma forma de representação política" (CAMPILONGO, 1987, p. 103 - 104).

fungíveis provoca desequilíbrios que colocam em risco a capacidade das instituições representativas desempenharem sua função específica".

319 Os movimentos sociais são caracterizados "pela autonomia em relação à representação política estatal e por sua capacidade de construir identidades políticas entorno de problemas inacessíveis às instituições tradicionais" (CAMPILONGO, 1987, p. 102).

320 O modelo "neocorporativo" se refere a uma representação de interesses particulares, que se opera mediante a atuação de "associações organizadas e especializadas (entidades diversas das empresas, das famílias, das cooperativas, dos clubes, das agências estatais, dos parlamentos)" "influenciando ou contestando as políticas públicas", por meio da intermediação entre "seus membros e vários interlocutores, especialmente o Estado" (CAMPILONGO, 1987, 105 - 106).

${ }^{321}$ Por exemplo, os movimentos sociais, ao contrário da representação política, não dispõem de mecanismos para reconhecer posições divergentes, mostrando-se inadequados para resolverem o problema da “institucionalização do conflito", o que só pode ser feito pela representação política (CAMPILONGO, 1987, 104). 
Quanto às corporações, como a democracia pressupõe a liberdade de associação, elas não representam alternativa à representação política nem são, em princípio, incompatíveis com a democracia. Diz-se que não são incompatíveis com a democracia em princípio porque, com a sua atuação na formulação das políticas públicas, pode ocorrer de a regra da maioria ser substituída por negociações baseadas em outros critérios e de a "soberania do parlamento" ser "violada pelo recurso crescente às formas 'contratadas' de solução dos conflitos sociais", favorecendo-se os grupos sociais mais articulados e ligados ao capital ${ }^{322}$ (CAMPILONGO, 1987, 107).

O controle soberano do povo sobre o Parlamento também sofre limitações decorrentes dos limites enfrentados pela regra básica de tomada de decisões ${ }^{323}$ da democracia representativa: a "regra da maioria",324.

De acordo com Campilongo (2000, p. 56 - 58), o apoio da maioria é considerado condição de legitimação do poder segundo o ideal democrático, porém o processo de decisão política enfrenta novas exigências que precisam ser atendidas pela democracia e pela regra da maioria, tais como rapidez, precisão e eficiência.

\footnotetext{
${ }^{322}$ Tais grupos são favorecidos porque "os arranjos corporativos implicam uma troca de benefícios entre o governo e as elites organizadas corporativamente; as decisões corporativas estão livres das pressões do processo eleitoral", de maneira que, por exemplo, problemas econômicos relacionados com demandas da sociedade são transformados em "assuntos técnicos que devem ser resolvidos por 'especialistas"'; embora o discurso do setor empresarial seja contrário à intervenção estatal na economia, preferem a "política elitista dos ajustes corporativos" do que as "demandas populares do processo eleitoral". Assim, a representação coorporativa que em princípio complementa a representação popular pode vir a substituí-la em diversos setores, com grandes riscos para a democracia (CAMPILONGO, 1987, 108).

${ }^{323}$ De acordo com Sartori, (1994, p. 289 - 298), as decisões coletivas apresentam custos internos (de tomada de decisões) e riscos externos (para os destinatários). Quanto maior o número de pessoas que participa da tomada de decisão, maiores são os custos e menores são os riscos, e vice-versa. A unanimidade é a regra de decisão que garante menores riscos, porém apresenta custos elevados, sendo até mesmo impraticável em grandes grupos. Nesses grupos, costuma-se adotar a regra da maioria, a qual diminui os custos, mas faz com que certa proporção da coletividade (a minoria) não tenha peso algum na decisão. A maioria pode ser qualificada, absoluta e simples. A escolha de uma delas se dá em função da importância do objeto da decisão e busca "um equilíbrio entre a conveniência (redução dos custos decisórios) e a segurança (redução dos riscos externos)".

${ }^{324}$ A regra da maioria constitui uma técnica decisória e democrática fundamental (CAMPILONGO, 2000, p. 55), presente nos mais diferentes seguimentos, como a casa, o trabalho, a economia e a política (CAMPILONGO, 2000, p. 28), e utilizada tanto no âmbito da escolha dos representantes políticos como no da deliberação no Parlamento e em outros órgãos colegiados (CAMPILONGO, 2000, p. 46). Campilongo (2000, p. 38 - 39) define a regra da maioria como "uma técnica rápida de tomada de decisões coletivas que maximiza a liberdade individual e assegura a ampla e igual participação política dos cidadãos, aproximando governantes e governados por meio de uma prática social de legitimação eventual, finita no espaço e no tempo, que sujeita as decisões à contínua revisão e mantém a sociedade unida". Ele (2000, p. 41) ainda salienta que "o ideal democrático do governo de todo o povo tem, na regra da maioria, a ferramenta capaz de torná-lo mais próximo da realidade. Nas condições de fragmentação, dissenso e complexidade do mundo contemporâneo, o princípio da maioria, por suas feições não discriminatórias e igualitárias, transforma-se na condição necessária, quando amplamente extensiva a todo o povo, para a aproximação entre governantes e governados".
} 
Uma primeira limitação da regra da maioria decorre da desconsideração da intensidade das preferências ${ }^{325}$, o que pode levar uma maioria indiferente com relação à determinada questão a prevalecer sobre uma minoria atuante e preocupada com a decisão a ser tomada. ${ }^{326}$ Em segundo lugar, "a maioria de um só voto é tudo, mas minoria de um só voto é nada". Em terceiro lugar, questiona-se se a regra da maioria pode ser utilizada legitimamente para qualquer objeto de deliberação, como, por exemplo, as questões técnicas altamente complexas com as quais se depara continuamente o Estado contemporâneo, especialmente se forem considerados colégios eleitorais compostos por muitos membros que não dispõem dos conhecimentos técnicos necessários sobre o assunto. Por outro lado, como já se discutiu anteriormente, existe o risco de se transformar "questões políticas em temas "técnicos"” com a finalidade de afastá-las dos processos decisórios democráticos. Em quarto lugar, existe o problema das "exigências inconsistentes" e inconciliáveis que costumam se apresentar para escolha majoritária, tais como diminuição dos tributos e ampliação dos serviços públicos. Em quinto lugar, como a regra da maioria se manifesta por meio de posições bastante simples (sim ou não), ela enfrenta dificuldades para atender à complexidade das decisões políticas do Estado contemporâneo, as quais envolvem muito mais variáveis. Em sexto lugar, a legitimação das decisões pela regra da maioria encontra limites no tempo e no espaço, pois ela só pode ser "legitimamente aplicável a fatos reversíveis ou corrigíveis no futuro", pois isso impede

\footnotetext{
325 Segundo a teoria do direito responsivo, a regra da maioria não deve ser esvaziada, mas seu potencial enquanto instrumento de legitimação das decisões políticas precisa ser relativizado. E aponta que de acordo com tal teoria, o princípio majoritário desconsidera a intensidade das preferências, limita os direitos das minorias e perde seu potencial legitimador no momento em que a implementação de políticas públicas escapa do controle da maioria. A teoria do direito responsivo, de Selznick e Nonet ,caracteriza o direito, na sua produção, pela grande participação popular (uma ordem legal mais aberta às influências sociais e à própria pressão da sociedade como mecanismo para obtenção de informações e corrigir seus erros), e, nos resultados, pela capacidade de responder aos anseios sociais. Teubner e Luhmann ressalvam que se trata de um direito com perfil de alto risco por se abrir demais às pressões do ambiente e poder perder sua capacidade de controle $\mathrm{O}$ autor salienta que a primeira característica do direito responsivo é "a soberania de propósitos e intenções sociais". E continua: "nisso reside o cerne de suas virtudes e dificuldades. A principal virtude, a permanente sensibilidade para os reclamos da sociedade. A maior dificuldade, forjar instituições aptas a conciliar racionalidade formal e racionalidade material, captando constantemente a intencionalidade social". Esse direito, de acordo com o citado autor, lida com as idéias de maior integração comunitária, cálculo de resultados previsíveis e consideração dos múltiplos interesses em disputa na elaboração das normas jurídicas e múltiplos centros de produção normativa. Ele se aproxima dos ideais democráticos de participação de todos no processo de tomada de decisões coletivas, reconhecendo a legitimidade dos múltiplos valores e o respeito dos direitos da minoria, estimulando-se a negociação e o compromisso. Porém, trata-se de uma concepção bastante idealista de sociedade e apresenta dificuldades, como a obtenção de integração numa sociedade complexa, e riscos, como a "politização descontrolada da vida social", a paralisia decisória e a dificuldade de se controlar novos centros de produção de direito. Para enfrentar essas dificuldades, o direito responsivo busca duas estratégias: o resgate da noção de legalidade enquanto instrumento para redução das arbitrariedades e a serviço da justiça substantiva; e a valorização da "função reguladora do direito", enquanto "processo de clarificação do interesse público". (CAMPILONGO, 2000, p. 57 - 63)

${ }^{326}$ Cf. BORSANI, 2004 p. 106 - 107, CAMPILONGO, 2000, p. 48, SARTORI, 1994, p. $300-302$.
} 
decisões diferentes por maiorias futuras, como também a alternância e a liberdade das futuras gerações. Em sétimo lugar, por meio da regra da maioria não se pode modificar o conteúdo ou as características dos direitos humanos, pois a democracia não consiste somente na prevalência da vontade da maioria, mas também significa proteção às minorias. Por fim, sabe-se que o poder dos grandes grupos econômicos influencia a opinião das pessoas e, portanto, a formação de maiorias. Em virtude disso, "a regra da maioria perde significativamente seu potencial legitimador". Diante desses fatos, Campilongo (2000, p. 47 - 54) conclui que, "desde que conjugados, a regra (da maioria) e seus limites são indispensáveis à democracia. Porém, incontáveis situações contemporâneas apontam para outras formas, mais legítimas e eficazes, de agregação de interesses".

Essas considerações permitem concluir que a realização da democracia por meio da representação política encontra muitos limites, mostrando-se incapaz de operar satisfatoriamente o controle político, sua função infungível. Da mesma maneira, a regra da maioria, instrumento fundamental por meio do qual a representação se opera também não resolve todas as questões que lhes são apresentadas. Porém, não existem alternativas capazes de substituir satisfatoriamente tanto a representação política como a regra da maioria. A alternativa que reta, então, é conviver com essas limitações, procurando minimizá-las, e aceitar-se o fato de que as decisões que afetam a coletividade podem ser tomadas em outros espaços, que não o estatal, pois o Estado não detém a exclusividade da esfera pública. Ressalta-se, todavia, que tais espaços de mediação podem completar o estatal-representativo, mas não substituí-lo.

\subsection{Controle Popular sobre o Parlamento por meio das Eleições.}

Depois desta breve apresentação sobre as características gerais da representação política e de alguns limites que enfrenta para viabilizar o controle democrático sobre o parlamento, passa-se a uma análise sobre o principal instrumento por meio do qual se tenta realizar essa tarefa: as eleições.

As eleições são expressões fundamentais da representação política nos regimes democráticos. Além de escolherem seus representantes políticos, os cidadãos, ao menos em tese, exercem um controle sobre eles durante o processo eleitoral, pois indicam suas preferências e julgam a atuação daqueles que já possuíam mandato. E como os políticos se 
preocupam permanentemente com sua eleição ou reeleição, haveria um poder contínuo dos eleitores sobre os eleitos. ${ }^{327}$

Para tanto, serão considerados basicamente três aspectos: os sistemas eleitorais, os partidos políticos e a influência dos meios de comunicação e do poder econômico sobre a representação política.

Existem dois modelos de sistema eleitoral ${ }^{328}$ : majoritário e proporcional. No primeiro, somente o grupo majoritário elege representantes e as minorias não participam do governo. Como vantagem deste sistema, aponta-se a definição do responsável pela política adotada, criando-se um vínculo mais forte entre representantes e representados. $\mathrm{O}$ sistema proporcional objetiva resolver o problema da representação das minorias, pois garantiria aos grupos minoritários a possibilidade de participação no governo ${ }^{329}$. Porém, ressalva-se que este sistema acarreta "uma diluição de responsabilidade e uma redução da eficácia do governo", além de não assegurar a plena representação das minorias, pois os grupos minoritários não têm condições de impor ao governo suas idéias frente à "preponderância de fato dos grandes partidos". Como alternativa a esses dois sistemas básicos há o de distritos, por meio do qual o colégio eleitoral é dividido em distritos pequenos, que elegem um deputado cada, com o objetivo de se estabelecer um relacionamento mais próximo entre o representante e o colégio eleitoral. Porém, este sistema também não resolve o problema da representação das minorias e pode fazer com

\footnotetext{
${ }^{327}$ Cf. GUIMARÃES, 2000, p. 12; SARTORI, 1962, p. 77 - 78. Lamounier (1996, p. 36 - 39) aponta que “o processo eleitoral-representativo caracteriza-se por uma tensão entre dois requisitos: a incerteza e a inteligibilidade". O primeiro consiste na escolha do voto do eleitor de maneira livre, não controlada por qualquer outro ator. $\mathrm{O}$ segundo consiste na possibilidade de o eleitor fazer escolhas entre alternativas políticas claramente distintas, de maneira que a eleição não seja uma "simples técnica de substituição de pessoas"; ou seja, requer-se a existência de "alternativas que façam sentido. Interlocutores autônomos e consistentes, e não conluios oligárquicos, com diferenciação apenas aparente".

${ }^{328}$ Silva $(1998$, p. 131 - 136) defende que a escolha do sistema eleitoral do Estado não seja feita a partir de critérios abstratos, mas sim a partir de uma avaliação sobre sua adequação prática à realidade e aos objetivos de sua adoção, tendo em vista, também que é desejável que as correntes de pensamento de todos os cidadãos estejam refletidas no Parlamento.

${ }^{329}$ Moraes $(2005$, p. 375$)$ aponta como vantagem do sistema proporcional a possibilidade de "garantir maior igualdade entre a maioria e a minoria na participação política". Kelsen (2009b, p. 73) aponta a importância do sistema proporcional para assegurar a existência de "uma oposição no parlamento", pois "sem esta, o procedimento parlamentar já não poderia cumprir sua verdadeira função", bem como para garantir a representação "de todos os grupos políticos, proporcionalmente à sua força", de maneira que o parlamento possa retratar "a real situação dos interesses" presentes na sociedade. Caggiano (1987, p. 182) também entende que o método de proporcional apresenta "maior grau de justiça". De acordo com Duverger (1962, p. 97; 106), nos sistemas de representação majoritária costuma ocorrer uma super-representação da maioria e uma sub-representação das minorias, enquanto que o sistema de representação proporcional assegura uma melhor representação das minorias. Já Laski (1932, p. 26 - 29) defende o sistema eleitoral majoritário e o bipartidarismo, por ser o método mais adequado para garantir a capacidade do governo impulsionar as atividades do Estado e de assegurar sua estabilidade e sua responsabilização. Além disso, assinala que o sistema proporcional diminuiria a responsabilidade dos representantes e destruiria a possibilidade de sua relação com os eleitores.
} 
que os representantes se preocupem somente com problemas regionais, deixando de lado as questões nacionais $^{330}$ (DALLARI, 2001, p. 190 - 196).

O principal aspecto positivo atribuído ao sistema majoritário de escolha dos representantes é a sua capacidade de assegurar a governabilidade por meio da formação de maiorias estáveis. Entretanto, o sistema não assegura esse resultado, pois ele também depende de outros fatores como a existência de um bipartidarismo, já que, quando existem mais partidos, a formação de uma maioria absoluta dependerá da votação obtida por eles (SILVA, 1998, p. 136 - 137).

Defende-se, também, no Brasil, o sistema majoritário por meio da votação em distritos eleitorais relativamente pequenos, sob os fundamentos da personalização da disputa com a redução do número de candidatos, o que permitiria que os eleitores os identificassem melhor, e a facilidade de o eleitor saber a quem procurar diante de uma necessidade, "já que cada distrito teria seu representante individualizado"331. Porém, os representantes eleitos não representam apenas a circunscrição que os elegeu, mas todo o povo, e não atuam sob o mandato imperativo. Além disso, havendo um único representante do distrito, aqueles que não têm as mesmas idéias ficariam sem representação, comprometendo-se a proteção das minorias ${ }^{332}$ (SILVA, 1998, p. 139 - 140).

Os sistemas majoritários apresentam vários problemas. Em primeiro lugar, em virtude de só se considerarem os votos dos vencedores de cada distrito eleitoral, costuma ocorrer distorções na representatividade quando se compara o total de votos de todos os distritos e o número de eleitos por partido ${ }^{333}$. Tais sistemas também apresentam a tendência de gerar bipolarização partidária, o que reduz as reais opções de escolhas dos eleitores a

\footnotetext{
${ }^{330}$ A fim de se conciliar representação justa com estabilidade política, Elster (2007, p. A 25) propõe a eleição proporcional combinada com cláusula de barreira entre três e cinco por cento dos votos, a fim de que pequenos partidos não possam chegar ao Parlamento. Ele entende, ainda, que o sistema de listas partidárias fechadas é antidemocrático, sendo que o ideal é combinar a influência dos partidos na formação das listas, mas deixando a "possibilidade de os eleitores modificarem-na".

${ }^{331}$ No Brasil, a adoção do voto distrital majoritário acabaria reforçando o caráter personalista das disputas eleitorais pelas vagas no Parlamento, o individualismo dos parlamentares e a "vinculação permanente dos representantes políticos à defesa de interesses locais, de forma a multiplicar o surgimento de vereadores federais" (COMPARATO, 1997, p. 92 - 93).

${ }^{332}$ Nesse sentido, Abranches (1988, p. 12) salienta que os sistemas majoritários, “em ambientes sociais plurais, tendem a estreitar excessivamente as faixas de representação, com o risco de simplificar as clivagens e excluir da representação setores da sociedade que tenham identidade e preferências específicas".

${ }^{333}$ Pode ocorrer até de os resultados serem invertidos, ou seja, de o partido com o maior número de votos em todo o território nacional ter menos representantes eleitos do que outro com menos votos, mas que venceu em mais distritos (SILVA, 1998, p. 141 - 142).
} 
somente duas muito semelhantes, pois, com o objetivo de não desagradar parcelas do eleitorado, os partidos procuram se posicionar no centro das alternativas programáticas ${ }^{334}$.

Os sistemas proporcionais apresentam algumas importantes vantagens. Primeiramente, todos os votos contam, ou para a eleição do representante, ou, pelo menos, para a composição do quociente partidário. Em segundo lugar, eles asseguram a representação das minorias na proporção de sua força. Em terceiro lugar, não estimula o voto útil (naquele que tem maiores chances de vencer), pois são maiores as chances de todos os candidatos conseguirem uma vaga no parlamento, o que garante a sinceridade do voto $^{335}$. Por fim, quando se adota o voto em partidos (o que é a regra geral) ${ }^{336}$, desestimula a personalização do voto e estimula a escolha por razões programáticas ${ }^{337}$ (SILVA, 1998, p. $141-146)$.

Costuma-se criticar o sistema proporcional devido ao "poder excessivo que é dado aos partidos políticos", especialmente no caso da adoção do sistema de listas bloqueadas, pois haveria uma despersonalização do voto. Entretanto, Silva (1998, p. 153) salienta que querer diferente, isto é, querer uma maior personalização da representação política, com o conseqüente enfraquecimento dos partidos políticos, é querer a situação atualmente vivida no Brasil, onde os partidos pouco ou nada significam e onde o controle da política fica restrito a um pequeno grupo de caciques políticos que são donos de siglas chamadas partidos.

A escolha do sistema eleitoral mais adequado para um Estado passa pela discussão do predomínio da representatividade (favorecida pelo proporcional) ou da governabilidade (beneficiada pelo majoritário). Silva (1998, p. 156 - 157) aponta que a primeira deve prevalecer, pois "assegurar a representatividade sem muito perder em governabilidade é muito mais fácil e freqüente do que o oposto". Isso porque, a ampliação

\footnotetext{
${ }^{334}$ Além disso, "a bipolarização, em conjunto com a personalização das eleições, pode gerar campanhas eleitorais estéreis do ponto de vista do conteúdo programático, já que passaria a ser mais importante a imagem dos candidatos do que as idéias por eles defendidas" (SILVA, 1998, p. 143).

335 Como, ao contrário dos sistemas majoritários, nos sistemas proporcionais com listas bloqueadas, os partidos políticos não precisam agradar a todos, é possível "maior sinceridade e estruturação dos programas partidários", o que, em longo prazo, "tende a fortalecer os partidos verdadeiros, depurando o quadro partidário e eliminando os chamados partidos de aluguel, meras siglas a favor do fisiologismo político". Apesar de os líderes políticos conservarem sua importância, não ocorre o "triunfo da imagem sobre a substância" (SILVA, 1998, p. 146).

${ }^{336}$ Comparato (1997, p. 91) salienta que no Brasil foi criado "um sistema, único no mundo, de representação proporcional com voto uninominal em lista aberta de candidatos".

337 Apesar de existir uma distância entre representantes e representados no sistema proporcional, ela não afeta "a qualidade do voto, pois o importante, para esse tipo de campanha, é menos a relação pessoal entre os candidatos e eleitores do que a possibilidade de divulgação dos programas partidários" (SILVA, 1998, p. 148).
} 
da representatividade é inerente ao sistema proporcional, enquanto a garantia da governabilidade é "mera expectativa" do majoritário.

Acompanha-se esse entendimento, pois os problemas existentes no sistema eleitoral brasileiro decorrem de outros fatores ${ }^{338}$, sobre os quais se tratará a seguir.

O sistema eleitoral brasileiro, baseado em "lista aberta", apresenta o efeito perverso de estimular a disputa intrapartidária. Isso ocorre, porque para um candidato ser eleito, além de o partido obter o quociente eleitoral, ele precisa conseguir mais votos do que seus colegas de partido, o que estimula o individualismo, as disputas internas, incentivando a indisciplina partidária e tornando "o papel dos partidos políticos ainda mais desprezível". Consequentemente, "a unidade e a coesão partidárias ficam totalmente comprometidas"339 (SILVA, 1998, p. 170).

Silva (1998, p. 171) salienta que, embora o personalismo na política brasileira não possa ser atribuído exclusivamente ao sistema eleitoral, "mais do que qualquer tradição personalista, é a adoção de listas não hierarquizadas, com a possibilidade de voto nominal, o fator que mais colabora para a fragilização do já frágil sistema partidário brasileiro" 340 .

338 Comparato (1997, p. 89 - 90) aponta que, dentre os vícios do sistema eleitoral brasileiro, "os mais importantes, pelos nefastos efeitos que provocam em toda a nossa política, são o personalismo dos candidatos a postos parlamentares e a super-representação estadual, desvirtuadora do princípio da soberania popular". Esses dois vícios têm como consequiências a "inconsistência partidária e a organização paralela de grupos de interesses apartidários no Congresso - as bancadas de ruralistas, empreiteiras, empresas de comunicação, sindicatos de trabalhadores, pastores evangélicos etc. - muito mais coerentes que partidos oficiais". Para combater esses vícios do sistema eleitoral brasileiro, Comparato (1997, p. 96 - 97) apresenta as seguintes propostas: "introdução, para a eleição dos componentes da Câmara dos Deputados, do sistema proporcional puro com votação em listas partidárias fechadas, em circunscrições eleitorais de tamanho equivalente, em todo o território nacional, fixando-se um piso nacional de votos dados a cada partido, como condição de sua representação na Câmara. adoção do mesmo sistema, com as adaptações necessárias, nas eleições às Assembléias Legislativas e Câmaras de Vereadores; exigência de domicílio eleitoral na circunscrição durante pelo menos quatro anos, para todos os candidatos a postos eletivos; redução de três para dois dos senadores eleitos por cada estado, com mandato de quatro anos; abolição dos suplentes de senador".

${ }^{338}$ Caggiano (1987, p. 182) também alerta que, "as cláusulas de exclusão, não poucas vezes acopladas à tecnicidade aritmética, produzem marcante ingerência no quadro da representação partidária, vedando o ingresso aos pequenos partidos na vida político parlamentar".

${ }^{339}$ Nesse sentido, Comparato (1997, p. 91) ressalta a necessidade de "despersonalizar a disputa eleitoral", de maneira que nas eleições parlamentares (com exceção da eleição para o Senado Federal) os eleitores escolham entre partidos e não entre candidatos, pois a incoerência do atual sistema "chega a tal extremo, que o pior adversário de um candidato a cargo parlamentar vem a ser o seu companheiro de partido com o mesmo perfil ideológico".

${ }^{340}$ Outra consequiência da personalização das campanhas é seu alto custo, pois com isso os candidatos tenham que fazer sua campanha individualmente. Isso faz com que, em regra, somente os candidatos com maior disponibilidade de recursos financeiros consigam se eleger. Com isso, o poder econômico se torna "mais decisivo do que as propostas políticas" e o personalismo cresce, pois cada candidato, a fim de obter recursos, faz suas alianças com os detentores do poder econômico. Embora seja normal a influência do poder econômico, não se pode admitir que seja fator decisivo no resultado das eleições, como vem ocorrendo no Brasil (SILVA, 1998, p. 172 - 173). A adoção de listas bloqueadas contribuiria muito para a redução dos 
O personalismo, na política brasileira, tem sua origem no início do período Republicano, quando se estabeleceu uma relação clientelista decorrente do domínio rural, na qual os eleitores trocavam seus votos para o "patrão político", de quem dependiam, pelo atendimento de "demandas privadas"341. Com o desenvolvimento dos meios de comunicação de massa, sugiram os "ídolos populares, desprovidos de idéias e de experiência política, com os quais a grande massa estabelece uma relação simbólica de culto e consagração pessoal"342 (COMPARATO, 1997, p. 89 - 90).

Diante disso, Silva (1998, p. 172) conclui que

\begin{abstract}
enquanto forem adotadas listas não hierarquizadas, com a possibilidade de voto nominal, as campanhas continuarão sendo feitas na base do compromisso e do carisma pessoal, e os partidos políticos, e conseqüentemente os programas partidários, continuarão a ser meras siglas e libretos inúteis e desconhecidos do eleitorado.
\end{abstract}

Portanto, o sistema de votação por lista partidária fechada, "ao publicizar todos os nomes que concorrem por uma legenda e ao vinculá-los em torno de linhas programáticas comuns, o eleitor tem a sua frente uma escolha efetiva, baseada não no nominalismo personalista, mas no projeto político que se pretende representar na sociedade"343 (ABRAMOVAY e PAULA, 2009, A 3).

Kelsen (2000b, p. 56) aponta que a perda do mandato pelos deputados que deixam seus partidos constitui uma maneira de responsabilizá-los perante os eleitores e uma "conseqüência natural do sistema de voto por lista vinculada", o que pressupõe "uma organização partidária sólida e relativamente estável dos eleitores".

Contra a adoção das listas bloqueadas, aponta-se o problema da dominação partidária, com a transformação de seus líderes em verdadeiros donos do partido. De fato esse risco existe, mas há como evitá-lo por meio da adoção de mecanismos democráticos para a definição da ordem das listas, como a realização de convenções partidárias

custos das campanhas, pois os partidos fariam uma campanha de suas propostas e candidatos como um todo, sem que houvesse necessidade de campanhas individuais (SILVA, 1998, p. 183).

${ }^{341}$ Cf. LEAL (1975).

342 Durante o período pré-eleitoral os partidos procuram personalidades populares para atuarem como "puxadores de votos" nas eleições, as quais, depois de eleitas, não apresentam nenhum compromisso partidário. (COMPARATO, 1997, p. 90 - 91).

${ }^{343}$ A adoção do sistema de listas bloqueadas ("aquelas cuja ordem de candidatos é previamente definida e inalterável”) juntamente com o voto único partidário sem a possibilidade de voto nominal é um mecanismo importante para que a democracia brasileira deixe de se basear em legendas de aluguel. Além disso, "esse fato tende, a longo prazo, a diminuir oi personalismo dominante nas eleições, porque, em primeiro lugar, nenhum candidato dependerá de sua votação para ser eleito, devendo todos lutar em conjunto para que seu partido tenha o maior número possível de votos e, em segundo lugar, porque os eleitores deverão votar em um partido, o que fará com que os votos tenham, com o passar do tempo, um conteúdo mais ideológicoprogramático do que pessoal. Com isso, haverá também um estímulo à "coesão e à unidade partidária".. 
democráticas, em que se deliberem de fato e não somente se homologue decisões previamente tomadas pelos líderes do partido (SILVA, 1998, p. 185 - 186).

Outra distorção do sistema eleitoral brasileiro é a desproporção da representatividade entre os estados da federação ${ }^{344}$. Como os deputados federais têm como função representar o povo e não seus estados, não há razões que justifiquem a desproporção da representação parlamentar em relação à população dos estados (SILVA, 1998, p. 177).

Silva (1998, p. 181) propõe a desvinculação entre circunscrição eleitoral e unidades federativas e a definição de todo o território nacional como circunscrição única. O sistema teria como vantagem garantir a máxima proporcionalidade da representação partidária. Porém, como todos os projetos são aprovados somente após votações na Câmara e no Senado, e, neste último, a representação é igual entre os estados, para se atingir o objetivo de superar as distorções de representatividade regional, seria necessária uma medida complementar: a "realocação de cadeiras no Senado", o que implicaria mudanças na estrutura federativa brasileira; ou a supressão do Senado, com a implantação de um Legislativo unicameral. No que se refere à criação de uma circunscrição nacional única, ela se mostra inviável com o sistema de listas partidárias abertas em que os deputados precisam fazer suas campanhas individuais, pois somente aqueles que dispusessem de muitos recursos teriam condições de fazer uma campanha nacional. Assim, o sistema só é viável com a concomitante adoção do sistema de listas bloqueadas (SILVA, 1998, p. 180 181).

Costuma-se apontar que, no Brasil, o excesso no número de partidos é um problema do sistema eleitoral $^{345}$. Todavia, a existência de muitos partidos políticos no Brasil, em si, não pode ser considerada um problema, pois, "se a sociedade é heterogênea, não há como querer, artificialmente, homogeneizar a representação política, simplesmente

\footnotetext{
${ }^{344}$ A representação dos estados na Câmara dos Deputados é proporcional à sua população, porém existe um mínimo de oito e um máximo de setenta deputados por estado (CF, art. $45, \S 1^{\circ}$ ), o que gera distorções na representatividade (TEMER, 2001, p. 126). Por exemplo, enquanto Roraima tem um deputado para cerca de trinta mil eleitores, São Paulo tem um para cada quatrocentos e oitenta e sete mil (SILVA, 1998, p. 169) Nesse sentido, Madson (1979, p. 138) ressalta, quanto à Câmara dos Representantes, que "o número de representantes de cada Estado deve ser proporcional à sua população".

${ }^{345}$ F. Santos (1997, p. 469) afirma que "os resultados obtidos por estudos mais recentes que tratam das relações Executivo-Legislativo no Brasil não ratificam, portanto, a visão de que as instituições políticas devem sofrer reformas no sentido da redução do número de partidos ou do aumento do controle do Executivo e das lideranças partidárias sobre o processo legislativo".
} 
deixando de lado aqueles que não alcançam uma porcentagem do total de votos" ${ }^{346}$. Portanto,

o que deve ser discutido é a representatividade dos partidos e não o seu número. Se há muitos partidos porque há fragmentação na sociedade, não há porque não aceitar esse fato. Mas não é bem essa a situação vivida atualmente no Brasil. A sobrevivência de partidos sem representatividade é, muitas vezes, garantida pelo sistema eleitoral (SILVA, 1998, p. 173).

Silva $(1998$, p. 173 - 174; 186) salienta que representatividade significa "um mínimo de apoio popular que justifique o acesso à Câmara dos Deputados, mínimo esse que não pode ser fixado aleatoriamente", ou seja, por meio de cláusulas de barreira ${ }^{347}$, mas se refere à obtenção do quociente eleitoral. O mecanismo do sistema eleitoral brasileiro que permite o acesso de partidos sem representatividade à Câmara dos Deputados é a possibilidade de coligações proporcionais. Assim, a solução para o excesso de partidos no Parlamento não exige a adoção de cláusulas de barreira, mas somente a proibição das coligações proporcionais $^{348}$.

Abranches (1988, p. 14) salienta que a permissão de coligações partidárias para as eleições proporcionais "subverte o quadro partidário, confundindo o alinhamento entre legendas e contaminando as identidades partidárias".

\footnotetext{
346 Abranches (1988, p. 13 - 14) destaca que a preocupação com a proliferação de partidos nos sistemas proporcionais se revela exagerada, pois existem "diferenças ponderáveis ente o número de partidos que disputam as eleições e o número de partidos com efetiva representatividade parlamentar". Além disso, "a capacidade de formar maiorias estáveis e a necessidade de recorrer a coalizões não são exclusivamente determinadas pela regra da representação, nem pelo número de partidos, mas também pelo perfil social dos interesses, pelo grau de heterogeneidade e pluralidade na sociedade e por fatores culturais, regionais e lingüísticos, entre outros, que não são passíveis de anulação pela via do regime de representação. Ao contrário, a tentativa de controlar a pluralidade, reduzindo artificialmente o número de partidos representados no parlamento e aumentando as distorções distributivas na ralação voto/cadeira, pode tornar-se um forte elemento de deslegitimação e instabilidade"

347 Caggiano (1987, p. 182) também alerta que, "as cláusulas de exclusão, não poucas vezes acopladas à tecnicidade aritmética, produzem marcante ingerência no quadro da representação partidária, vedando o ingresso aos pequenos partidos na vida político parlamentar".

${ }^{348}$ Cunha $(1995$, p. 5 - 9) afirma que a corrente antiliberal defende três propostos principais de reforma eleitoral-partidária: a) implantação do voto distrital (puro ou misto); b) implantação de redutores ao pluralismo partidário; c) implantação do voto facultativo. Segundo ele, o voto distrital tem como objetivo a redução do número de partidos a dois ou três, ocultando seu objetivo principal de redução da representatividade, tendo como resultado o "monopólio partidário, a domesticação da política, a manutenção do status quo", pois poderia excluir da representação política "imensas massas já excluídas dos direitos básicos da cidadania", mediante a constituição de maiorias por imposição dos que controlam o poder. Ele assinala que "os vícios do processo eleitoral brasileiro nada têm a ver com a proporcionalidade. Decorrem, basicamente, da exagerada influência do poder econômico - em que se inclui o poder da mídia - assim como da fraude, no momento das apurações". Do que decorre a necessidade de se regular essa influência a fim de garantir a igualdade de competição entre candidatos e partidos.
} 
Embora a própria Constituição prescreva que a representação política deva ser partidária, a "inexistência de uma coesão partidária" permitiu o surgimento de bancadas corporativas, as quais reúnem parlamentares de diferentes partidos com o objetivo de “defender opiniões de seu grupo profissional ou religioso". Assim, apesar de ser normal a existência de parlamentares oriundos de diferentes seguimentos da sociedade que votem em várias situações defendendo seus interesses, o problema reside no fato de orientarem suas decisões "apenas e tão somente por princípios corporativos, o que colabora ainda mais para perpetuar o caótico quadro parlamentar brasileiro". Esse problema também pode ser superado mediante o fortalecimento da coesão e da unidade partidária, com a adoção das listas bloqueadas e da fidelidade partidária (SILVA, 1998, p. 182 - 184)

Depois de discutir os limites e as possibilidades que os sistemas eleitorais apresentam para o controle democrático do Parlamento, é preciso tecer mais algumas considerações sobre os partidos políticos ${ }^{349}$, pois são as instituições que se colocam como intermediárias entre os eleitores e os candidatos, ${ }^{350}$ e é em torno deles ${ }^{351}$ que se organiza o Estado democrático moderno (LASKI, 1932, p. 24 - 26).

Weber (1964, p. 228) define partidos como formas de "socialización" que descansando en un reclutamiento (formalmente) libre, tienem como fin proporcionar poder a sus dirigentes dentro de uma asociación y otorgar por esse medio a sus membros activos determinadas probabilidades ideales o materiales (la realización de fines objetivos o 11 logro de ventajas personales o ambas cosas). ${ }^{352}$

Em tese, com os partidos políticos ${ }^{353}$, a representação deixou de ser apenas um processo de seleção de governantes, tornando-se "uma verdadeira opção entre programas governamentais" (CAGGIANO, 1987, p. 17).

Nesse sentido, Caggiano (1987, p. 191) destaca que

\footnotetext{
${ }^{349} \mathrm{O}$ partido político é uma instituição indispensável nos sistemas políticos em que há sufrágio universal para “organizar y activar la voluntad política de la masa electoral” (LOEWENSTEIN, 1986, p. 94).

350 Elster (2007, p. A25) afirma, inclusive, que uma verdadeira democracia se distingue de um mero arremedo de democracia se houver partidos políticos que se alternam no poder.

${ }^{351}$ Esses partidos, que podem ser compreendidos como instituições que reúnem um grupo de pessoas em torno de um conjunto de idéias com o objetivo de conquistar o poder político para colocá-las em prática, apresentam diferentes classificações. Internamente, costumam ser divididos em partidos de quadro e de massa; externamente, os sistemas de partidos são classificados, de acordo com o seu número, de partido único, bipartidários e pluripartidários; quanto ao âmbito de atuação, existem os partidos com vocação universal, nacional, regional e local (DALLARI, 2001 p. 160 - 166). Cf. BASTOS (1988, p. 254 - 259).

${ }^{352}$ Cf. FERREIRA (1995, p. 235).

${ }^{353}$ Os partidos políticos no seu sentido moderno surgem a partir de 1850 os quais se "impuseram como veículo natural da representação política" (DALLARI, 2001 p. 160 - 166). Os partidos políticos encontram sua origem nas eleições e no Parlamento. Começam a ser organizados a partir da formação de grupos de parlamentares com afinidade política ou proximidade de regiões de origem, ou da comitês eleitorais destinados à arrecadação de recursos para as campanhas eleitorais (CAGGIANO, 1987, p. 181 - 182).
} 
mais que simples escolha, o processo eleitoral, hoje, identifica a mecânica através da qual o corpo de representados promove sua aprovação ou desaprovação quanto ao programa e à atuação governamental, expressa suas preferências, manifestando-se a favor de um indivíduo ou de uma plataforma de governo.

Além disso, na prática das eleições ${ }^{354}$, os eleitores exercem sua escolha dentro dos limites estabelecidos pelos partidos, pois são os partidos que definem os candidatos que poderão ser escolhidos pelos eleitores (DUVERGER, 1962, p. 115).

Duverger (1970, p; 386 - 387) afirma que a introdução do partido no cenário político fez com que a democracia passasse por grandes transformações em relação às disputas individuais do século XIX, pois, com eles, um elemento novo passa a se interpor entre o povo e o parlamento, já que é o partido que seleciona os candidatos que serão submetidos à escolha dos eleitores ${ }^{355}$.

Além da campanha eleitoral propriamente, que tem em vista a eleição dos candidatos, os partidos fazem uma campanha visando à difusão de suas idéias, de seus programas, aproveitando-se das condições favoráveis que o período eleitoral propicia à ação sobre a opinião pública e ao interesse das pessoas por política (DUVERGER, 1970, p. 400).

Um grave problema dos partidos políticos, apontado por Duverger (1970, p. 455 459), é sua estrutura interna autocrática e oligárquica, opondo-se às concepções tradicionais de democracia. Porém, o autor conclui que a única forma viável de democracia é aquela praticada por meio dos partidos, pois somente eles são capazes de viabilizar a eleição de uma elite governante saída do povo.

Não obstante a importância dos partidos políticos, eles vivem, há algum tempo, uma crise dentro do contexto da crise do Estado Social. Essa crise é explicada, primeiramente, pela "politização da esfera econômica e a mercantilização da esfera

\footnotetext{
${ }^{354}$ A favor da eleição por meio dos partidos políticos argumenta-se que reúnem opiniões convergentes que criam uma força capaz de conquistar o poder político, e facilitam a "identificação das correntes de opinião e de sua receptividade pelo meio social". Contra sua atuação aponta-se que o povo, "mesmo quando o nível geral da cultura é razoavelmente elevado, não tem condições para se orientar em função de idéias e não tem sensibilidade por debates em torno de opções abstratas", de maneira que a escolha do eleitor é regida por seus interesses pessoais. Além disso, como a ação dos membros dos partidos muitas vezes não se pautada por seu programa, são vistos como "meros instrumentos para a conquista do poder". Diante dessas ponderações, Dallari (2001, p.166 - 167) conclui que "os partidos poderão ser úteis, apresentando mais aspectos positivos que negativos, desde que sejam autênticos, formados espontaneamente e com possibilidade de atuar livremente".

${ }^{355}$ Nesse sentido, o autor (1970, p. 388; 405) afirma que "em um regime pluripartidário o papel dos eleitores se resume a escolher entre os candidatos cooptados pelos partidos; a cooptação constitui o primeiro ato da operação eleitoral, da qual a eleição é, apenas, o segundo"
} 
pública", acompanhada da "perda da centralidade do conflito entre capital e trabalho", o qual continua a existir, mas convive com outros tipos de conflituosidade ${ }^{356}$; pela excessiva “fragmentação dos interesses sociais", com consequente perda de significado da noção de bem comum com a qual trabalha a representação política, já que a sociedade apresenta “distintos e incompatíveis interesses setoriais", o que leva a representação política a se transformar na representação de interesses particulares ou de setores; pelo "fenômeno das agregações transitórias", ou seja, os indivíduos e grupos se agregam e desagregam em tono de interesses momentâneos. Diante disso, os partidos políticos se mostram incapazes de canalizar os conflitos sociais, pois operam a partir da lógica tradicional da contradição entre capital e trabalho, enquanto nas sociedades contemporâneas os conflitos se apresentam de maneira muito mais difusa. Além disso, não se mostram capazes de "filtrar as demandas sociais e transformá-las em decisões políticas" (CAMPILONGO, 1987, p. 97 $-100)$.

Em decorrência da indiferenciação dos programas partidários, de sua profissionalização e da perda de suas ideologias após a queda do muro de Berlim, o eleitor, ao votar, sente que, "seja qual for o sentido do seu sufrágio, os decisores por ele eleitos pouco ou nada mudarão em relação ao "status quo"” (MORAIS, 2004, p. 142).

Para finalizar este tópico, será feita uma discussão sobre os limites que os meios de comunicação e o poder econômico impõem ao controle democrático sobre o Parlamento.

Schwartzenberg (1978, p. 127 - 329), antes do advento da internet e no auge da televisão, apontava a "espetacularização" da política. Nesse fenômeno, observa-se a transformação dos políticos em atores, que encenam um espetáculo de ilusões, no qual se reforça a personalização do poder e os cidadãos se tornam meros espectadores. Neste processo, a imprensa assume uma grande força, pois é por meio dela que os políticos conquistam a opinião pública. Outro recurso utilizado é o das sondagens de opinião, que permitem descobrir a preferência dos eleitores e preparar o "produto" que lhes agrade, permitindo-se, inclusive, a construção de candidaturas destituídas de quaisquer convicções. O espetáculo do poder substitui, assim, a política real, com a consequente alienação dos cidadãos, manipulados e sem autonomia.

\footnotetext{
${ }^{356}$ Por exemplo, os conflitos relacionados às questões ambientais e à melhoria dos serviços públicos.
} 
Já na era da internet e das redes globais de televisão, Ianni (1999, p. 256 - 270) fala sobre o "príncipe eletrônico" 357 , destacando o papel da mídia global que "registra e interpreta, seleciona e enfatiza, esquece e sataniza o que poderia ser a realidade e o imaginário". A criação deste imaginário, é feita por uma "vasta e complexa rede de articulações corporativas envolvendo mercados e idéias, mercadoria e democracia, lucratividade e cidadania". Nesse contexto, não se pode considerar como neutras as tecnologias da mídia inseridas nas atividades sociais. O "príncipe eletrônico", que representa as classes ou blocos de poder dominantes, em diferentes graus, conforme a realidade institucional e cultural, "influencia, subordina, transforma ou mesmo apaga partidos políticos, sindicatos, movimentos sociais, correntes de opinião, legislativo, executivo e judiciário". 358

A esse respeito, Bonavides (2004, p. 29 - 30) afirma que somente nas aparências a vontade expressa pela democracia representativa é formada pelo povo ou pelas correntes majoritárias da sociedade, pois, na verdade, ela é constituída pelo poder dos meios de comunicação de massa mediante a manipulação da opinião, os quais são controlados por oligopólios econômicos e absolutamente livres de controle popular democrático.

Como os cidadãos, em geral, não têm acesso direto aos acontecimentos políticos, são informados por meio da mídia de massa, a qual filtra as informações e influencia a opinião pública. Assim, o controle dos meios de comunicação de massa é um recurso político muito importante (DAHL, 2005, p. 257).

Ressalta-se que, além de alienante, o "espetáculo do poder personalizado" também é "dispendioso". Isso cria uma "disparidade de meios de campanha entre os candidatos, dependendo dos recursos de que eles dispõem”. Corre-se, ainda, o risco de se ver a "classe política transformar-se em grupo teatral mantido pela classe dominante (SCHWARTZENBERG, 1978, 323 - 328).

\footnotetext{
${ }^{357}$ Segundo Ianni $(1999$, p. 256 - 257) "o príncipe eletrônico é uma entidade nebulosa e ativa, presente e invisível, predominante e ubíqua, permeando continuamente todos os níveis da sociedade, de âmbito local, regional e mundial. É o intelectual coletivo e orgânico das estruturas e blocos de poder presentes, predominantes e atuantes em escala nacional, regional e mundial, sempre em conformidade com os diferentes contextos socioculturais e político-econômicos desenhados no novo mapa do mundo".

358 Sobre esse assunto, Mayer $(1997$, p. 37 - 47) destaca que os meios de comunicação de massa são "indústrias de notícias, máquinas-imagem, fantasias e sonhos", que têm como objetivo fundamental o lucro e não a prestação de serviços de informação para os cidadãos. $O$ autor pondera, todavia, que a influência da manipulação da opinião pública pelos meios de comunicação de massa é tanto maior quanto forem o analfabetismo e a despolitização da sociedade. Cf. Schumpeter, 1961, p. 320 e Morais, 2004, p. $142-143$.
} 
Como o dinheiro pode ser utilizado para influenciar os detentores de cargos públicos, os detentores do poder econômico ocupam uma posição muito melhor do que a média dos cidadãos. O dinheiro é utilizado para pressão financeira, corrupção e na contribuição para campanhas eleitorais, sendo esta última a forma mais poderosa de influenciar a política devido aos crescentes custos das campanhas (DAHL, 2005, p. $240-$ 242).

Essa influência do dinheiro na política ocorre porque os que detêm o poder econômico precisam das leis para fazerem valer seus desejos, de maneira que precisam influenciar os legisladores (DAHL, 2005, p. 246 - 247).

Singer (2007, p. A3) denomina esse fenômeno de "financeirização das eleições" e aponta que, em virtude dos altos custos das campanhas eleitorais, o Brasil assiste a uma “colonização da política pelo dinheiro", de maneira que a igualdade de direitos entre todos os cidadãos se torna mera figura retórica, pois, de fato, existem duas categorias de cidadãos:

os de primeira classe, que, por serem doadores importantes - diretamente ou por meio de empresas que dirigem -, ficam perto da cabine de comando e têm um impacto direto sobre a conduta dos representantes. Acabam por se constituir numa aristocracia disfarçada. A massa do eleitorado, por seu turno, é relegada ao vagão da segunda classe, do qual influi pouco na direção a ser seguida.

Diante disso, o referido autor (2007, p. A3) indica alguns caminhos: proibição de doações de empresas para partidos e candidatos; estabelecimento de um teto para doações de pessoas físicas a fim de se evitar que "grandes fortunas individuais possam desequilibrar o resultado dos pleitos"; e o aumento da capacidade de fiscalização do poder público e da sociedade, por exemplo, por meio de investigação minuciosa de certo número de contas sorteadas, além da que se realiza com todas, a fim de se coibir as doações não declaradas de recursos. Em seguida, conclui que é preciso inverter a lógica atual segundo a qual

o diálogo e a referência dos candidatos tendem a se deslocar dos eleitores para os financiadores. Isso porque a vitalidade das instituições representativas depende de sua abertura ao cidadão comum e aos movimentos de base da sociedade. Desse ponto de vista, libertar as campanhas eleitorais do domínio econômico é $\operatorname{decisivo~}^{359}$.

\footnotetext{
${ }^{359}$ Nesse sentido, Abramovay e Paula (2009, A 3) afirmam que o atual sistema de financiamento das campanhas eleitorais "vincula candidatos a financiadores" e acarreta custos muito maiores do que haveria em um sistema de financiamento público "quer pelas brechas à corrupção, quer pelos direcionamentos e ineficiências assumidos pelos eleitos em troca de viabilização eleitoral". Cf. Caggiano, 1987, p. 31 - 32; 105 $-106)$.
} 
O Conselho Federal da Ordem dos Advogados do Brasil apresentou um projeto de reforma política que propõe, entre outras mudanças, o financiamento público das campanhas eleitorais ${ }^{360}$ e o estabelecimento do montante de doações que cada candidato estará autorizado a receber pela Justiça Eleitoral em cada eleição, com a previsão das penas de impossibilidade de tomar posse ou perda do mandato (se já empossado) no caso de infração. Isso porque, nas palavras de Britto (2007, p. A3) "nos termos atuais, é o capital privado que as financia, cobrando depois em moeda política - isto é, em atos governativos - as doações, parte expressiva delas em caixa dois". Ocorrendo até mesmo o fato de "grandes conglomerados financeiros financiarem indistintamente todos os candidatos, tornando-se previamente os verdadeiros vencedores das eleições”. A consequência desse sistema, assinala o autor, é, "além das numerosas transgressões éticas que temos visto, a privatização do Estado, que passa a ter suas políticas revertidas em benefícios dos que financiaram os eleitos, e não do contribuinte que o sustenta com seus impostos".

Conclui-se que o sistema eleitoral mais adequado para o Brasil é o proporcional com listas partidárias fechadas, pois garante maior representatividade e contribui para o fortalecimento dos partidos políticos. Porém, é necessário democratizar o sistema decisório interno dos partidos e proibir as coligações proporcionais. É preciso também estabelecer a igualdade de representatividade entre a população dos diferentes estados. Por fim, destacase a necessidade de se limitar as despesas e se estabelecer o financiamento público de campanhas e criar mecanismos de democratização dos meios de comunicação a fim de combater o domínio do poder econômico e, especialmente dos meios de comunicação de massa, sobre o processo político.

As limitações do processo eleitoral como instrumento de controle popular sobre o Parlamento demonstra a necessidade de se desenvolver outros meios de controle. No tópico seguinte, cuidar-se-á deste assunto. ${ }^{361}$

\footnotetext{
${ }^{360}$ Schwartzenberg $(1978$, p. 341) destaca a necessidade de se garantir a absoluta publicidade das despesas eleitorais, limitá-las (estabelecendo-se tatos para impedir campanhas dispendiosas), e financiá-las com recursos o Estado (a fim de evitar o "conluio dos eleitos e dos interesses privados" e garantir a eqüidade no financiamento de todos os candidatos). Assim sendo, o autor poderá: "será um preço excessivo para separar a política e os negócios, para evitar o conluio dos eleitores e dos interesses privados? Afinal de contas, as eleições constituem uma atividade de interesse geral, um serviço público que merece ser financiado pela coletividade. A quem ocorreria lamentar que o erário público subvencione a democracia?"

${ }^{361}$ Nesse sentido, Caggiano (1987, p. 196 - 197) afirma que "o momento eleitoral, no entanto, não se consubstancia em fórmula exclusiva para o estabelecimento do debate entre governados e governantes e, sequer, para a prática da censura quanto a política por esses praticada. A esse passo, é de lembrar o fato de que a representação política implica, na realidade, no governo do povo por seus representantes. As relações de intercomunicação que se estabelecem não vêm delineadas em linha direta - governados/governados, ou
} 


\subsection{Outros meios de Controle Popular sobre o Parlamento.}

Como assinala Burdeaus $(1975$, p. 30 - 32), o poder não tem somente sua origem no povo, "mas permanece nele". Portanto, o controle popular sobre o Parlamento não se revela democrático, nem eficiente, se ficar restrito ao momento eleitoral ${ }^{362}$.

Entretanto, como assevera Comparato (2007b, p. A3), "nosso país logrou realizar notável façanha política: instituiu e fez funcionar, por mais de um século, uma República de interesse privado ${ }^{363}$ e uma democracia sem povo", aceitando-se, com exceção dos períodos ditatoriais, que tudo transcorre "nos quadros da normalidade republicana e democrática". Diante disso, o autor questiona: "será possível que ainda não aceitamos o fato elementar de que, numa democracia, é o povo que constitui o Poder Legislativo e não o contrário?"

O controle popular sobre o Parlamento, além das eleições, deve abranger a fixação de diretrizes e metas de médio e longo prazo, o acompanhamento do cumprimento dessas orientações políticas (e sua revisão) e a responsabilização dos parlamentares (como também do Chefe do Poder Executivo) se não forem cumpridas.

A fixação de diretrizes e metas pode ocorrer por diferentes formas: ratificação de reformas constitucionais por meio de referendo; ${ }^{364}$ definição periódica direta, mediante

seja, entre aqueles personagens que atuam na órbita política e os que apreciam a sua atuação. Tal relacionamento vem traçado numa linha paralela, entre os governantes e um corpo especialmente designado pelos cidadãos para representá-los no desempenho da tarefa censora. É a atribuição cometida aos parlamentos, que, ainda, nesse papel, representam o povo, investindo-se no poder de censores do comportamento e da eficaciedade governamental".

${ }^{362}$ Nesse sentido, Cunha (1995, p. 10 - 11) afirma que "a participação política não pode ser privilégio de apenas uma parcela da população; e que ela não se reduz ao direito de votar e ser votado. Enquanto não houver, por parte de cada pessoa, a possibilidade real de participar, de influir e de exercer cidadania ativa, a democracia continuará sendo uma ficção". Offe (1984b, p. 265) afirma que as eleições gerais funcionam como uma espécie de "cheque em branco" para as decisões independentes de consenso", ou seja, como uma "barreira institucional que permite ignorar ou disfarçar contestações à legitimidade das decisões tomadas".

363 Existem interesses organizados de poderosos blocos econômicos que acompanham atentamente e pressionam direta e continuamente o Parlamento, enquanto a maioria dos cidadãos não presta atenção nos acontecimentos do Legislativo. Esse fato ajuda a explicar porque que o Congresso toma decisões que favorecem tais interesses (ARNOLD, 1990, p. 3). Os grupos de pressão procuram influenciar as decisões parlamentares no sentido de se beneficiar as pessoas e instituições que representam. Apresentam alguns aspectos positivos, como constituir um instrumento de informação para os parlamentares e chamar a atenção para questões que não receberiam a devida consideração política se não existissem. Por outro lado, apresentam pontos negativos, tais como estarem voltados para interesses setoriais em detrimento do interesse coletivo, a ameaça à independência dos órgãos públicos, o uso de meios ilícitos de atuação, como a prática da corrupção, e a prevalência dos interesses dos que detêm maior poder econômico. Além disso, existe o risco de existirem grupos de interesse não organizados que não serão contemplados por não serem capazes de exercerem a adequada pressão sobre o poder político (BASTOS, 1988, p. 244 - 245).

${ }^{364}$ Cf. LOEWENSTEIN, 1986, p. 65. 
procedimento eleitoral, das diretrizes gerais dos governos ${ }^{365}$; garantia da participação democrática de todos os interessados nos processos legislativos e administrativos referentes a matérias que lhes sejam pertinentes, por meio de espaços institucionalizados ${ }^{366}$.

Em segundo lugar, devem ser criados canais permanentes e institucionalizados de acompanhamento, fiscalização, manifestação e pressão dos eleitores sobre as atividades parlamentares. Para tanto, é necessário que exista transparência absoluta em todas as ações do Parlamento (reuniões, votações, despesas etc.), ${ }^{367}$ que os parlamentares prestem, permanentemente, conta de seu trabalho, ${ }^{368}$ e que se constitua uma verdadeira esfera pública.

Se as diretrizes fixadas pela população não forem cumpridas, não deve ser necessário esperar a eleição seguinte para mudar a composição ao Parlamento, deve-se responsabilizar $^{369}$ os representantes no próprio curso do mandato mediante o instituto do "recall",370

Nesse sentido, Bonavides (2004, p. 482 - 483) afirma que os Parlamentos serão verdadeiros órgãos de representação popular quando o povo tiver neles "presença e

365 Schwartzenberg (1978, p. 344 - 345) destaca que "em oportunidades separadas por intervalos suficientemente reduzidos, obedecendo ao ritmo das eleições legislativas ou presidenciais, o eleitor deve ter o direito de escolher pessoalmente - direta e imediatamente - as linhas mestras pelas quais se deverão pautar em seguida os governantes enquanto durar a legislatura ou o mandato presidencial. Não se trata apenas de decidir quem irá governar. O problema todo, o verdadeiro problema é: quem governará para fazer o quê? Para seguir que linha política?" Isso porque "sem programas verdadeiros, o sufrágio fica privado de linguagem. Converte-se num ato de submissão ou de hostilidade". Devem ser estabelecidas opções claras e precisas entre as quais o povo possa escolher, "sem ambigüidades nem equívocos", "sem demagogia nem ilusões". Após isso, os eleitos devem manter um diálogo constante com os eleitores, de maneira que a democracia seja "permanente".

${ }^{366}$ Cf. MORAIS, 2004, p. 134 - 136, REAL, 1974, p. 15 e GORDILLO, 1981, p. 26 - 28.

${ }^{367}$ ARNOLD, 1990, p. $272-275$.

${ }^{368}$ No sistema de poder fechado das democracias marxistas, não havia o mandato imperativo, porém os eleitos não dispunham de uma liberdade incondicional como na democracia clássica, sendo que a Constituição soviética prescrevia que os deputados devem prestar contas de seu trabalho aos eleitores e, a qualquer tempo, serem responsabilizados por eles, podendo, inclusive, terem seus mandatos revogados (BURDEAUS, 1975, p. 117 - 118);

${ }^{369}$ Loewentein (1986, p. 70) aponta que “El punto crítico de control político yace em la possibilidad de exigir responsabilidad política ${ }^{369}$. Existe responsabilidad política cuando um determinado detentador tiene que dar cuenta a outro detentador del poder sobre el cumplimiento de la función que le há sido asignada, por ejemplo, el gobierno al parlamento, el parlamento al gobierno y, em último término, ambos al electorado".

${ }^{370}$ Locke (2003, p. 109) já destacava que, embora o Parlamento seja o poder supremo entre os constituídos, ele está submetido ao poder supremo do povo, que pode "afastar ou modificar o legislativo, se constatar que age contra a intenção do encargo que lhe confiaram". Para enfrentar o problema de se tornar mais efetivo o controle parlamentar algumas propostas apresentadas pela doutrina são a responsabilização pessoal dos Ministros por iniciativa do Parlamento e a especialização das funções de controle em comissões, ressalvandose, porém, que nenhuma mudança institucional surtirá os efeitos almejados se não for acompanhada por uma mudança de postura dos parlamentares (MEDAUAR, 1990, p. 130). 
ingresso soberanos", ou seja, quando existir efetivo controle popular sobre seus atos e decisões, inclusive podendo destituir seus membros que contrariarem os anseios populares.

Dentre os itens do projeto de reforma política elaborado pelo Conselho Federal da Ordem dos Advogados do Brasil e encaminhado para a Câmara dos deputados no início de dois mil e sete, encontra-se o "recall"371, instituto que permite a revogação popular de mandatos eletivos. Britto (2007, p. A3) aponta que, se esse instituto estivesse em vigor, a atitude dos parlamentares seria diferente, pois, hoje, não se sentem obrigados a prestar contas ao eleitor, voltando a lhe dar satisfação somente na época de novas eleições. Tratase, portanto, de "um instrumento que dá ao cidadão meios de cobrar condutas e compromissos" 372 .

É preciso, contudo, fazer algumas ressalvas às propostas apresentadas. Primeiramente, não se pode colocar uma ênfase exagerada nas mudanças institucionais como forma de melhorar o controle popular sobre o Parlamento. Não obstante a importância dessas reformas, pouco valem sem um esforço coletivo voltado para assegurar o cumprimento das normas vigentes e a mobilização popular em torno dos grandes desafios deste momento histórico (CUNHA, 1995, p. 11). Para tanto, faz-se necessária a formação política da população, proporcionando a compreensão de todos sobre como funciona o Estado e como as decisões políticas se relacionam diretamente com o quotidiano das pessoas (LASKI, 1932, p. 44). Além disso, é necessário um controle democrático com ampla participação dos destinatários, dos sistemas de educação e da

\footnotetext{
${ }^{371}$ Kelsen $(2000$ b, p. 53 - 55) assinala que não é possível nem adequado um retorno ao mandato imperativo, porém deve ser considerada a idéia de "um controle permanente dos deputados por parte dos grupos de eleitores constituídos em partidos políticos". Isso porque, "um contato permanente, estabelecido entre deputados e corpo eleitoral e garantido por lei, poderia reconciliar as massas com o princípio parlamentar". Além disso, o autor assinala que "a irresponsabilidade di deputado perante seus eleitores, sem dúvida uma das causas essenciais do descrédito em que caiu a instituição parlamentar, na verdade não é um elemento necessário como transparecia da doutrina do século XIX". O recall (ou direito de revogação) consiste na "faculdade conferida aos cidadãos de destituírem os representantes governantes de suas funções, na hipótese de sua atuação se afigurar desconforme ao interesse público ou à opinião pública. É admitido no direito constitucional como mecanismo aplicável nos mais diversos setores da atividade governamental, abrangendo tanto o Legislativo, como a Administração e a esfera do Judiciário" (CAGGIANO, 1987, p. 21). Cf. BONAVIDES, 2004, p. 30 - 31 e LASKI, 1932, p. $34-35$.

${ }^{372}$ Lamounier (2007, A3) critica o projeto de reforma política apresentado pela OAB, afirmando que, por descrer totalmente na democracia representativa, "restringe drasticamente o espaço da representação" e propõe um modelo de “"cesaroamarquismo', um híbrido de princípios opostos, ambos levados ao paroxismo". Segundo o autor, isso ocorre porque, por um lado, amplia o arbítrio do Poder Executivo, ao permitir que convoque plebiscitos sem necessidade de autorização do Congresso Nacional e, por outro, "institui a intervenção popular no processo decisório numa escala jamais praticada em nenhum país, por meio do chamado recall', o qual teria lógica em pequenas circunscrições a fim de revogar mandatos parlamentares específicos em sistemas distritais puros, mas não para revogar o mandato de todos os parlamentares e do próprio Presidente da República de uma só vez, decorridos doze meses das eleições, mediante convocação da maioria da Câmara ou de dois por cento do total de eleitores.
} 
televisão ${ }^{373}$. Sem isso, não é viável o fortalecimento da democracia e a construção da cidadania e do senso de responsabilidade do povo perante as grandes questões públicas (GORDILLO, 1981, p. 31 - 33).

Ressalta-se, por fim, que o controle popular sobre o Parlamento não se limita aos instrumentos formais. Assim, para concluir este tópico, serão apresentadas algumas idéias da teoria do discurso ${ }^{374}$, de Habermas, que constituem um importante instrumental para um controle popular informal sobre o Parlamento ${ }^{375}$.

Habermas (1997a, 171 - 199; 213) afirma que a legitimidade do direito decorre do procedimento democrático pelo qual ele se instaura, e não de sua forma ou de um conteúdo moral $^{376}$. Assim sendo, de acordo com a "teoria do discurso", a "soberania do povo significa que todo o poder político é deduzido do poder comunicativo dos cidadãos". Diante disso, a validade de qualquer tipo de norma depende da manifestação dos atingidos que participam de "discursos racionais",377.

Sob essa perspectiva, todos os cidadãos deveriam participar da "competência legislativa", pois são os únicos capazes de produzir "o poder comunicativo de convicções comuns". Como não é possível que todos os cidadãos se reúnam para interagir nessa prática, existe a alternativa do "princípio parlamentar da criação de corporações deliberativas representativas". Todavia, é preciso "complementar a formação da opinião e da vontade parlamentar, bem como os partidos políticos, através de uma formação informal da opinião na esfera pública política, aberta a todos os cidadãos”. Essa formação informal

\footnotetext{
${ }^{373}$ Nesse sentido, Grau (2008, p. 146) destaca que se deve investigar "as condições que permitem a reprodução da corrupção, as estruturas de poder que definem a sorte das eleições, a conspiração permanente do mass-midia que não permite a educação das massas, mas a quer como um objeto permanente de manipulação, controle e submissão".

${ }^{374}$ Cf. ROCHA, 2004, p. $89-90$.

${ }^{375}$ Habermas (1997b, p. 127) ressalta que "é possível enfrentar a autoprogramação de uma administração independente e a delegação não-autorizada de resoluções do Estado através de um deslocamento da divisão funcional de poderes no interior do próprio sistema administrativo - por intermédio de novos elementos de participação e de controle, oriundos de esferas públicas específicas".

${ }^{376}$ A teoria do discurso "coloca no centro o processo político da formação da opinião e da vontade, sem, porém entender a constituição do Estado de direito como algo secundário" (HABERMAS, 1997b, p. 21). A esse propósito, vale mencionar a teoria da democracia deliberativa. Tal teoria entende que o valor deste regime político se encontra no seu processo decisório. Exige-se que as decisões sejam tomadas mediante discussões públicas, nas quais seja assegurada a igualdade (material e formal) e a liberdade plena (não devem sofre qualquer tipo de coação) de participação institucionalizada de todos os interessados na defesa de suas posições e opiniões, mediante a argumentação racional. A participação não pode se limitar à escolha entre as opções dadas, devendo abranger a própria formulação da agenda e a definição das opções. Esse procedimento possibilita percepção e a correção de erros que ocorreriam se a decisão fosse tomada por um indivíduo ou por um pequeno grupo (COHEN, 1999. p. 186, 193 - 194, ELSTER, 1998, p. 1 e NINO, 1996, p. 67 - 68; 106 137).

377 Habermas (1997a, p. 208) assevera que "se a negociação de compromissos decorrer conforme procedimentos que garantem a todos os interesses iguais chances de participação nas negociações e na influenciação recíproca, bem como na concretização de todos os interesses envolvidos, pode-se alimentar a suposição plausível de que os pactos a que se chegou são conforme a eqüidade".
} 
da opinião pública "prepara a formação política da vontade influindo nela" mediante um livre fluxo de opiniões em espaços protegidos por direitos fundamentais ${ }^{378}$ (HABERMAS, 1997a, p. $213-214)$.

Como nas deliberações sobre os interesses da comunidade, "todos os membros têm que poder tomar parte no discurso, mesmo que os modos sejam diferentes", Habermas (1997, p. 227 - 228) ressalta que "a participação simétrica de todos os membros exige que os discursos conduzidos representativamente sejam porosos e sensíveis aos estímulos, temas e contribuições, informações e argumentos fornecidos por uma esfera pública pluralista, próxima à base, estruturada discursivamente, portanto diluída pelo poder". Nesse sentido, o autor (1997, p; 229) acrescenta que

a formação política da vontade, organizada em formas de um poder político legislativo, destruiria a base civil de seu próprio funcionamento racional, caso ela tapasse as fontes espontâneas das esferas públicas autônomas e se encapsulasse em relação ao fluxo de temas, contribuições, informações e argumentos, que flutuam livremente numa esfera pré-política estruturada igualitariamente ${ }^{379}$.

Assim, forma-se um fluxo de comunicação entre "formação pública da vontade, decisões institucionalizadas e deliberações legislativas" que pode transformar a opinião pública em normas postas pelo Parlamento. Isso porque “opiniões públicas representam potenciais de influência política, que podem ser utilizadas para interferir no comportamento eleitoral ou na formação da vontade das corporações parlamentares, governos e tribunais" ${ }^{380}$ (HABERMAS, 1997b, p. 22; 97).

Hebermas (1997b, p. 94), todavia, ressalva que a "opinião pública não é representativa no sentido estatístico", desta forma, não pode ser confundida com “resultados de pesquisa de opinião". Além disso, ele (1997b, p. 23) lembra que a “opinião pública, transformada em poder comunicativo segundo processos democráticos, não pode

\footnotetext{
${ }^{378}$ Para que o debate atinja seus objetivos, é necessário que sejam asseguradas as oportunidades adequadas para participação de todos, bem como que esses tenham acesso a todas as informações necessárias para realizar suas críticas e expressar suas opiniões (GRIFFITH, RYLE, WHEELER-BOOTH, 1989, p. 10).

${ }^{379}$ Essa relação entre Parlamento e esfera pública no modelo da teoria do discurso não se confunde, todavia, nem com a democracia plebiscitária (segundo a qual existiria uma vontade popular hipotética a ser manifestada diretamente pelo povo), nem com a representativa (segundo a qual somente as corporações representativas por meio da deliberação independente da vontade real do povo seriam capazes de estabelecer o "bem comum hipotético") (HABERMAS, 1997a, p. 229 - 230).

${ }^{380}$ A evolução dos regimes democráticos ao longo do século XX se caracterizou pela ampliação dos participantes do processo político e pala maior "porosidade" e sensibilidade dos representantes à opinião pública, ou seja, às demandas dos representados e de organizações da sociedade, o que constitui, inclusive, requisito da legitimidade da representação política (LAMOUNIER, 1996, p. 34).
} 
'dominar' por si mesma o uso do poder administrativo; mas pode, de certa forma, direcioná-lo."

A formação da opinião pública transformada em "poder comunicativo" se dá na esfera pública ${ }^{381}$, a qual Habermas (1997b, p. 91) define como

uma caixa de ressonância onde os problemas a serem elaborados pelo sistema político encontram eco. Nesta medida, a esfera pública é um sistema de alarme dotado de sensores não especializados, porém, sensíveis no âmbito de toda a sociedade. Na perspectiva de uma teoria da democracia, a esfera pública tem que reforçar a pressão exercida pelos problemas, ou seja, ela não pode limitar-se a percebê-los e a identificá-los, devendo, além disso, tematizá-los, problematizálos e dramatizá-los de modo convincente e eficaz, a ponto de serem assumidos e elaborados pelo complexo parlamentar. E a capacidade de elaboração dos próprios problemas, que é limitada, tem que ser utilizada para um controle ulterior do tratamento dos problemas no âmbito do sistema político.

Existem grupos de interesse que procuram ocupar esferas públicas já constituídas para tirarem proveito delas no atendimento de seus objetivos específicos. Pode ocorrer, também, de as esferas públicas serem dominadas "pelo poder e pela mídia", a qual se encontra cada vez mais centralizada devido à "crescente complexidade" e ao "aumento do capital" necessário para funcionar. Entretanto, a submissão da esfera pública ao poder dos meios de comunicação de massa ocorre somente quando a esfera pública está "em repouso", pois, "a partir do momento em que acontece uma mobilização, as estruturas sobre as quais se apóia a autoridade de um público que toma posição começam a vibrar. $\mathrm{E}$ as relações de forças entre a sociedade civil e o sistema político podem sofrer modificações" (HABERMAS, 1997b, p. 96; 106 - 113).

Diante dessas considerações, Habernas (1997b, p. 114 - 115) conclui que, não obstante as grandes dificuldades a serem enfrentadas, é plausível que

os atores da sociedade civil, até agora negligenciados, podem assumir um papel surpreendentemente ativo e pleno de consequiências, quando tomam consciência da situação de crise. Com efeito, apesar da diminuta complexidade organizacional, da fraca capacidade de ação e das desvantagens estruturais, eles têm a chance de inverter a direção do fluxo convencional da comunicação na esfera pública e no sistema político, transformando destarte o modo de solucionar problemas de todo o sistema político.

381 Habermas (1997b, p. 92) também descreve a esfera pública como "uma rede adequada para a comunicação de conteúdos, tomadas de posição e opiniões; nela os fluxos comunicacionais são filtrados e sintetizados, a ponto de se condensarem em opiniões públicas enfeixadas em temas específicos”. 
Conclui-se que o controle popular sobre o Parlamento, além das eleições, deve abranger a fixação de diretrizes e metas de médio e longo prazo, o acompanhamento do cumprimento dessas orientações políticas e a responsabilização dos parlamentares se não forem cumpridas, sobretudo por meio do instituto do "recall". Todavia, não se pode atribuir exclusivamente às reformas institucionais a responsabilidade por resolver todos os problemas da política. Da mesma maneira, não é somente por meio de canais institucionalizados que o povo pode controlar o Parlamento. Isso também pode ser feito valendo-se de métodos informais, como a formação informal da opinião pública na esfera pública, aberta a todos os cidadãos, a qual pode influenciar as decisões políticas. Para tanto, requer-se um Parlamento poroso a uma opinião pública permanentemente mobilizada.

\subsection{Conclusões do Capítulo.}

1. A realização da democracia por meio da representação política encontra muitos limites, mostrando-se incapaz de operar, satisfatoriamente, o controle político, sua função infungível. Da mesma maneira, a regra da maioria, instrumento fundamental por meio do qual a representação se opera, também não resolve todas as questões que lhes são apresentadas. Porém, não existem alternativas capazes de substituir satisfatoriamente tanto a representação política como a regra da maioria. A alternativa que resta, então, é conviver com essas limitações, procurando minimizá-las, e aceitar-se o fato de que as decisões que afetam a coletividade podem ser tomadas em outros espaços, que não o estatal, pois o Estado não detém a exclusividade da esfera pública. Ressalta-se, todavia, que tais espaços de mediação podem completar o estatal-representativo, mas não substituí-lo.

2. O sistema eleitoral mais adequado para o Brasil é o proporcional com listas partidárias fechadas, pois garante maior representatividade e contribui para o fortalecimento dos partidos políticos. Porém, é necessário democratizar o sistema decisório interno dos partidos e proibir as coligações proporcionais. É preciso também estabelecer a igualdade de representatividade entre a população dos diferentes estados. Por fim, destacase a necessidade de se limitar as despesas, estabelecendo-se o financiamento público de campanhas, e criar mecanismos de democratização dos meios de comunicação a fim de combater o domínio do poder econômico, especialmente dos meios de comunicação de massa, sobre o processo político.

3. O controle popular sobre o Parlamento, além das eleições, deve abranger a fixação de diretrizes e metas de médio e longo prazo, o acompanhamento do cumprimento 
dessas orientações políticas e a responsabilização dos parlamentares se não forem cumpridas, sobretudo por meio do instituto do "recall". Todavia, não se pode atribuir exclusivamente às reformas institucionais a responsabilidade por resolver todos os problemas da política. Da mesma maneira, não é somente por meio de canais institucionalizados que o povo pode controlar o Parlamento. Isso também pode ser feito valendo-se de métodos informais, como a formação informal da opinião pública na esfera pública, aberta a todos os cidadãos, a qual pode influenciar as decisões políticas. Para tanto, requer-se um Parlamento poroso a uma opinião pública permanentemente mobilizada. 


\section{CAPÍTULO 4 - PERSPECTIVAS SOBRE A ATUAÇÃO DO PARLAMENTO NO CONTROLE DEMOCRÁTICO DO PODER.}

Neste capítulo, não se pretende retomar cada um dos pontos principais discutidos ao longo desta dissertação, pois isso será feito nas Conclusões. O que se propõe, é retomar a questão inicial que motivou esta pesquisa: em que medida o Parlamento é capaz de exercer, eficazmente, o controle do poder político, no contexto da globalização capitalista, com o objetivo de contribuir com a concretização dos direitos humanos econômicos e sociais?

A fim de responder esta pergunta, adotou-se um modelo ideal a ser alcançado: o Estado Democrático de Direito, o qual não se trata, em nenhum lugar do mundo, de uma realidade perfeita e definitivamente acabada, mas apresenta uma dimensão utópica, pois está em constante realização.

O Estado Democrático de Direito tem como fim supremo a garantia a todos os cidadãos dos direitos humanos fundamentais e a realização da justiça material, respeitandose as liberdades civis e políticas. Tais direitos vinculam o Estado e os poderes privados, pois igualmente tendem ao abuso e geram desigualdades. Da mesma maneira que as liberdades públicas impedem que sejam tomadas decisões que as violem, sobre questões de sobrevivência não se pode deixar de decidir. Todavia, não se trata de, simplesmente, garantir condições mínimas de bem-estar e compensar as desigualdades, mas, sim, de transformar as estruturas da sociedade. Como essa tarefa requer uma realocação dos recursos materiais, exige-se a regulação da ordem econômica e social pela vontade popular democraticamente manifestada. Livre de controle democrático, o poder econômico passa a controlar o Estado, e as injustiças se multiplicam.

A atuação do Estado Democrático de Direito ocorre, sobretudo, por meio das políticas públicas, que representam a concretização dos direitos mediante a atuação positiva do Estado. As principais políticas públicas devem ser o desenvolvimento econômico e social sustentável e a eliminação das desigualdades, o que requer o planejamento do futuro vinculado à ideologia constitucional e à busca de transformação dos status quo.

O controle democrático sobre o poder do Estado constitui condição de legitimação e eficiência do Estado Democrático de Direito. Isso não significa que o povo deve exercer a dominação direta, o que se revela impossível, mas o poder de mando: a prerrogativa de o superior impor decisões ao inferior, por meio de instrumentos como 
aprovação e modificação da Constituição, aprovação de metas de médio e longo prazo, eleição e destituição de representantes e mobilização de apoio e reprovação mediante mecanismos institucionalizados e espontâneos que questionem permanentemente o Estado diante do não atendimento dos direitos econômicos e sociais. Diante da indispensabilidade da representação política, é preciso tornar os políticos responsáveis. Aqui, a participação política adquire uma perspectiva de reforma da sociedade e cumpre um importante papel de contrabalançar os interesses particulares de políticos, de tecnocratas e de grupos econômicos a fim de que o Estado se constitua em verdadeira esfera pública. Para tanto, além de instituições, é necessário formar uma cultura política democrática.

A partir desses objetivos do Estado Democrático de Direito, fixou-se qual deve ser a missão institucional do Parlamento: legislação e controle do poder político, sendo a primeira compreendida como uma manifestação especial da última. Como controle do poder político pelo Parlamento compreende-se não somente a apuração de irregularidades e a punição de atos de corrupção, mas, principalmente, o direcionamento das ações do Estado para a concretização dos direitos humanos sociais e econômicos, ou seja: o estabelecimento da orientação política do Governo mediante a edição de normas que fixem diretrizes e metas essenciais a serem atingidas, inclusive em matéria de política econômica, a partir dos direitos e das linhas gerais previstos na Constituição. Para tanto, as políticas públicas devem ser formuladas no interior do Parlamento e seu controle sobre o orçamento deve ser ampliado. Depois disso, compete-lhe a fiscalização do cumprimento de suas orientações, tornando transparentes as ações do Executivo e submetendo-as ao debate público, de maneira que se constitua um verdadeiro espaço público para a definição democrática dos rumos do Estado. Na hipótese de não cumprimento de suas diretrizes e de não se atingirem, injustificadamente, as metas, o Parlamento deve dispor de mecanismos para aplicação de sanções e de outras medidas corretivas.

Porém, o campo do dever ser é confrontado e desafiado pela realidade.

Espera-se um Parlamento republicano e democrático, orientado pelo ideal constitucional de superação das desigualdades sociais, um poder, que por sua natureza conflitual, impulsione o Estado para realizar as políticas públicas inclusivas e emancipatórias. Mas o que se encontra é um Parlamento impregnado por um elemento histórico-cultural brasileiro que limita, drasticamente, suas possibilidades de exercer o controle democrático do poder político: o patrimonialismo.

Predomina, no Brasil, desde os tempos da colonização, a confusão entre o público e o privado. A cultura do favorecimento dos amigos, da formação de clientelas 
políticas e a naturalização da corrupção impedem que o Estado, e em especial o Parlamento, constituam uma verdadeira esfera pública, ou seja, um espaço de mediação dos interesses coletivos em que todos os interessados sejam igualmente considerados.

Essa indiferenciação entre o público e o privado, no desenvolvimento das atividades parlamentares, tem como resultado o desinteresse em se promover o controle democrático do poder com o objetivo de se concretizarem os direitos econômicos e sociais. Controle, transparência, responsabilização e institucionalização de direitos não interessam à cultura patrimonialista que prefere a opacidade, a irresponsabilidade política e o clientelismo que permitem a perpetuação no poder e perpetuam a miséria.

Esses elementos demonstram que, no Brasil, não se pode falar que atualmente se vive uma crise do Parlamento ${ }^{382}$, ou que o sistema representativo, em virtude de fatores específicos deste tempo, não é capaz de canalizar as demandas sociais. O Estado brasileiro nunca constitui uma verdadeira esfera pública ou se aproximou do ideal do Estado de Bemestar social.

A essa limitação histórico-cultural para a atuação do Parlamento no controle democrático do poder se soma, mais recentemente, um fenômeno mundial que afeta, diretamente, a já precária capacidade de intervenção heterônoma do Estado: a globalização capitalista.

Com isso, o Estado brasileiro, que já não se mostrava capaz de concretizar os direitos econômicos e sociais, enfrenta, agora, maiores dificuldades ainda, pois a realização desses direitos depende do controle sobre variáveis que se encontram fora do domínio do Estado $^{383}$

Isso quer dizer que o Estado, em especial o brasileiro, nada pode fazer? Que o Parlamento não tem razão de existir? ${ }^{384}$

\footnotetext{
${ }^{382}$ Habermas (1997b, p. 83 - 84) salienta que "quando os processos de sintonia entre Estado e os atores sociais tornam-se independentes em relação às esfera pública e à formação da vontade parlamentar, resultam prejuízos, tanto do ponto de vista da legitimação, como do conhecimento. Sob ambos os pontos de vista, recomenda-se que a base ampliada do saber de uma administração reguladora assuma feições de uma política deliberativa, que se caracteriza pelo debate público entre especialistas e contra-especialistas, controlado pela opinião pública".

383 O controle democrático do Parlamento sobre o governo da economia não é eficiente (BOBBIO, 2000, p 104), mesmo porque sua jurisdição se limita às fronteiras nacionais, enquanto os sistemas econômicos e financeiros são "desterritorializados e policêntricos" (FARIA, 2003, p. 11). Habermas, (1997b, p. 61) adverte para o fato de que, desde os anos sessenta, começam a ser notados os limites da capacidade de regulação do Estado devido a vários sistemas e organizações que escapam da sua capacidade regulatória, enfraquecendose, por outro lado, laços de representatividade.

${ }^{384}$ Tojal $(2002$, p. 4) ressalta que "por detrás da pós-modernidade representada pelo colapso dos paradigmas políticos e jurídicos (separação de poderes e princípio da reserva legal, para referir alguns), resta a perenidade de exigências modernas, fundamentalmente o controle do poder político pois se, com efeito, as respostas
} 
Não, o Estado e o Parlamento apresentam um papel importante. Porém diante dos condicionamentos internos e externos, não se pode esperar que, exclusivamente por meio da ação do Estado controlada (no sentido forte) pelo Parlamento, seja possível a concretização dos direitos econômicos e sociais no Brasil. Essa missão terá que ser compartilhada com outros atores nos planos nacional e internacional, como organizações internacionais (governamentais ou não-governamentais), movimentos sociais, agentes econômicos e organizações da sociedade civil em geral $^{385}$.

Quais são, então, os limites e as possibilidades de atuação do Parlamento no controle democrático do poder político a fim de que sejam concretizados os direitos econômicos e sociais? O que pode ser feito diante do déficit de representatividade e de eficiência no desempenho do papel atribuído ao Parlamento?

Os limites estão dados: a cultura patrimonialista e a globalização. Diante do patrimonialismo, algumas reformas institucionais podem contribuir para superar, mas não se trata de missão fácil, dado o seu enraizamento histórico. Perante a globalização, pouco também se pode fazer isoladamente, pois a construção de uma globalização alternativa, inclusiva, emancipatória, depende de uma ação coordenada de Estados nacionais e organizações internacionais (governamentais ou não governamentais), ou redes de organizações nacionais.

A propósito das limitações da democracia representativa, Santos (2002, p. 32) aponta que

$$
\begin{aligned}
& \text { o modelo hegemônico de democracia (democracia liberal, representativa), apesar } \\
& \text { de globalmente triunfante, não garante mais que uma democracia de baixa } \\
& \text { intensidade na privatização do bem público por elites mais ou menos restritas, na } \\
& \text { distância crescente entre representantes e representados e em uma inclusão } \\
& \text { política abstrata feita de exclusão social. Paralelamente a este modelo } \\
& \text { hegemônico de democracia, sempre existiram outros modelos, como a } \\
& \text { democracia participativa ou a democracia popular, apesar de marginalizados ou } \\
& \text { desacreditados. }
\end{aligned}
$$

Quanto às possibilidades, dependem, inicialmente, do reforço dos mecanismos de controle popular sobre o Parlamento e da repolitização das decisões que afetam a

institucionais do final do século XVIII estão em crise, as razões de suas formulações restam na mais absoluta ordem do dia".

385 Offe (1984b, p. 277) afirma que "a competência ampliada do Estado social na esfera dos problemas estruturais de caráter sócio-econômico não está em harmonia com sua capacidade de se desincumbir dessa carga de tarefas segundo diretivas políticas determinadas". Diante disso, Offe (1984b, p. 281) questiona o próprio "monopólio formal dos órgãos do aparelho estatal quanto às decisões obrigatórias ao nível da sociedade global", ou seja, a pretensão do Estado de "representar com exclusividade os interesses gerais". 
coletividade. É preciso retirar o manto de neutralidade técnica de inúmeras decisões nas esferas econômica e social, o qual esconde interesses econômicos particulares. Toda intervenção, pública ou particular, no campo da ordem econômica e social deve ser politizada, ou seja, compreendida dentro da característica conflitual da sociedade, a fim de que todos os interesses sejam igualmente considerados e todas as decisões sejam submetidas a controles democráticos institucionalizados ou informais.

Portanto, o sistema político-representativo precisa de reformas. Porém, mais do que reformá-lo, a sociedade precisará desenvolver outros meios de controle democrático e de mediação política.

O Parlamento tem amplas possibilidades de contribuir com a concretização dos direitos econômicos e sociais, se assumir o papel de controlar o poder político, no sentido de direcionamento, supervisão e fiscalização, submetido ao mais amplo controle popular. Porém, devido às limitações que se apresentam, nem o Parlamento, nem o Estado podem reivindicar para si a exclusividade da mediação política 


\section{CONCLUSÕES}

Após as discussões realizadas ao longo desta dissertação, apresentam-se as seguintes conclusões:

1. O poder político consiste na capacidade de o Estado, por meio de normas jurídicas e da força submetida ao direito, cumprir seu fim que é a realização do bem comum de um povo situado em um determinado território. Essa capacidade, dialeticamente, é determinada e participa da determinação da base econômica; enfrenta tendências inatas ao abuso e ao fato de estar a serviço do poder econômico, às quais deve se contrapor o controle democrático; e precisa, constantemente, se legitimar para se manter, o que depende do atendimento simultâneo de requisitos formais e materiais, tarefa diante da qual se apresentam grandes dificuldades.

2. Controlar, democraticamente, o poder político, não significa a simples contenção do poder a fim de evitar abusos, característica do Estado Liberal que serviu aos interesses de manutenção do sistema capitalista, sem nenhuma preocupação com a democracia material, também não se refere à crença utópica de um governo direto em uma sociedade com o grau de complexidade da contemporânea. Trata-se do controle dos atos dos governantes dentro de um sistema representativo, porém no sentido forte de direcionamento do poder, de estabelecimento de metas e diretrizes mediante planos, orçamentos e políticas públicas, bem como da responsabilização daqueles a quem compete a sua execução, com o objetivo perseguido pelo Estado Democrático de Direito de implantar, plenamente, os direitos humanos e fazer justiça material.

3. As funções do Parlamento são essencialmente duas: a legislativa e a de controle. Entende-se, em primeiro lugar, que sua atuação administrativa não constitui uma função, mas somente um meio para exercê-las. Da mesma maneira, representação e legitimação não são funções do Parlamento, mas, respectivamente, o fundamento e a consequência de seu exercício. Ou seja, o Parlamento legisla e controla o poder político porque representa o povo, e pelo exercício dessas funções, legitima, democraticamente, tal poder. Quanto à função legislativa, compreende-se que ela abrange a elaboração de emendas à Constituição (pois também são normas produzidas pelo Parlamento, sendo apenas de espécie diferente). Por fim, entende-se que a função de controle abrange a orientação política do Estado (mediante a definição de objetivos e diretrizes, bem como a escolha de membros de outros órgãos), a formação de lideranças políticas e a 
responsabilização dos executores das políticas (o que inclui fiscalização, investigação e julgamento político de autoridades). Aliás, a própria função legislativa, de certa forma, pode ser compreendida como uma manifestação do controle do poder político exercido pelo Parlamento.

4. Não se pode compreender, dentro da perspectiva de um Estado Democrático de Direito, o controle político exercido pelo Parlamento simplesmente como contenção do poder pelo poder. Muito menos se pode reduzir tão importante papel institucional à apuração de irregularidades e punição de atos de corrupção. O papel do Parlamento, submetido ao controle popular, tal como definido no primeiro item deste capítulo, é direcionar as ações do Estado para a concretização dos direitos humanos sociais e econômicos. Para tanto, estabelecendo um permanente canal de comunicação com o povo, o Parlamento deve estabelecer a orientação política do Governo, mesmo dentro do sistema Presidencialista, mediante a edição de normas que fixem diretrizes e metas essenciais a serem atingidas, inclusive em matéria de política econômica, a partir dos direitos e das linhas gerais previstos na Constituição. Depois disso, compete-lhe a fiscalização do cumprimento de suas orientações, tornando transparentes as ações do Executivo e submetendo-as ao debate público, de maneira que se constitua um verdadeiro espaço público para a definição democrática dos rumos do Estado. Na hipótese de não cumprimento de suas diretrizes e de não se atingirem, injustificadamente, as metas, o Parlamento deve dispor de mecanismos para aplicação de sanções e de outras medidas corretivas. Salienta-se que, em termos de políticas sociais, o Parlamento dispõe (e faz uso) de uma ampla competência legislativa. Todavia, a concretização desses direitos depende de dois fatores: a política econômica e a definição e aplicação do orçamento público. Quanto ao primeiro, o Parlamento se encontra quase que totalmente excluído. No que se refere ao orçamento público, trata-se do principal mecanismo de direcionamento das ações do governo de que o Parlamento dispõe, todavia, ele também sofre grandes limitações. Assim, os instrumentos de controle relacionados à fiscalização dos atos do Executivo pelo Parlamento constituem um mecanismo complementar à sua primeira forma de atuação que é a fixação das metas e diretrizes. Desta maneira, sem a definição da orientação política do Estado pelo Parlamento, sua atuação fiscalizadora perde grande parte de seu valor. Por outro lado, de nada adianta a clara definição das metas e diretrizes sem uma eficiente fiscalização e sem os mecanismos de correção e de sanção no caso de seu descumprimento. Em termos estruturais, a viabilização dessas funções depende, sobretudo, do fortalecimento das Comissões Permanentes. 
5. Em sentido amplo, a globalização é um fenômeno que acompanha a humanidade ao longo de toda sua história. Porém, em sentido estrito, trata-se de um processo de integração sistêmica da economia no âmbito mundial, iniciado nos anos setenta e oitenta do século XX sob o impulso dos avanços tecnológicos, especialmente no campo da informática, da uniformização do padrão monetário e do avanço das políticas neoliberais, principalmente a liberalização do fluxo de mercadorias e capitais. A globalização não se viabilizou independentemente do Estado, mas como fruto de uma política para ela voltada. Como consequências fundamentais, a globalização capitalista apresenta: uma drástica redução da capacidade de intervenção do Estado em matéria econômica; concentração de poder econômico e renda; destruição ambiental; e coloca em questão o próprio sentido e o alcance da democracia representativa. Trata-se, ainda, de um contexto histórico em que os conflitos se manifestam de maneira plural e diversificada, não se processando como conflitos de classe, e no qual se enfraquecem os vínculos de solidariedade e se fortalece o individualismo.

6. O contexto da globalização impõe drásticos limites para a atuação do Parlamento no controle democrático do poder político com o objetivo de promover a concretização dos direitos econômicos e sociais, basicamente, porque sua atuação é restrita aos limites territoriais, enquanto as decisões econômicas são tomadas no âmbito global. São, na verdade, limites não somente do Parlamento, mas do Estado Nacional como um todo. Ressalta-se que esse fato não é uma consequência inevitável do progresso científico e tecnológico, mas fruto de decisões políticas orientadas pela ideologia neoliberal. Todavia, tomadas essas decisões em diferentes partes do mundo, não há como voltar atrás, muito menos por meio de ações isoladas do Estado. Assim, o Estado, como também o Parlamento têm um papel importante a cumprir na regulação econômica e no combate aos efeitos perversos da globalização capitalista. Porém, essa atuação encontra limites que não podem ser superados por quaisquer reformas institucionais ou mudanças políticas internas, dependendo de decisões no plano internacional. Nesse sentido, as possibilidades que se abrem, não são para o Parlamento, mas para a cooperação global, não por um regresso ao passado, não por menos globalização, mas sim por mais globalização: por uma globalização que não se limite à livre circulação de capitais e mercadorias, mas que abranja a equalização das condições de vida em patamares dignos para toda a humanidade. Isso, todavia, dependerá da atuação das organizações internacionais, governamentais ou nãogovernamentais. 
7. Embora o Estado tenha passado por muitas transformações, permanece a necessidade de controlar seu poder, não só para limitá-lo contra o arbítrio, mas também para direcioná-lo para a concretização dos direitos econômicos e sociais. Porém, os mecanismos a serem utilizados para tanto não podem ser formulados a partir dos modelos de Estado e de sociedade dos séculos XVIII e XIX. Assim sendo, o princípio da separação de poderes rigidamente interpretado se encontra superado, porém a idéia de racionalização do poder que o inspirou continua viva. Portanto, o Executivo deve ser dotado dos meios necessários para atender às demandas sociais, porém deve desempenhar essa tarefa orientado por diretrizes fixadas pelo Parlamento (por sua vez submetido ao controle popular), e os mecanismos necessários para seu controle devem ser aprimorados a fim de torná-los mais eficazes.

8. A própria dinâmica de funcionamento do Parlamento já apresenta limites ao cumprimento de sua missão institucional, os quais giram em torno de cinco questões básicas: ausência de domínio sobre informações e conhecimentos técnicos; dificuldade de formação de consensos; tempo do processo legislativo; centralização do processo decisório; e a característica histórico-cultural patrimonialista do Estado brasileiro. Tais limites precisam ser enfrentados por meio de mudanças institucionais que facilitem o processamento dos conflitos, descentralize o sistema decisório, de maneira que se torne mais ágil e democrático, e fortaleça os mecanismos de fiscalização pela oposição. Porém, no atual contexto, o patrimonialismo se revela como um desafio difícil de ser transposto.

9. A transferência de funções normativas do Parlamento para o Executivo, sobretudo em matéria econômica, é inevitável, diante das próprias características do processo legislativo. Além disso, representa uma necessidade para a concretização dos direitos econômicos e sociais, pois isto exige a regulação da economia. Todavia, essa função do Executivo só pode ser realizada dentro dos parâmetros constitucionais e legais fixados pelo Parlamento, sendo que, em caso de não serem respeitados, a burocracia deve se submeter ao controle tanto do Judiciário como do Parlamento, cabendo a este último a responsabilização política e a correção de rumos.

10. As decisões tomadas pela tecnocracia são falsamente despolitizadas, ou seja, permanecem políticas, mas são levadas para arenas decisórias imunes ao controle democrático. Portanto, as decisões dos tecnocratas, inclusive em matéria econômica, devem ser tratadas como políticas e submetidas aos mecanismos de controle democrático. Assim sendo, o Parlamento deve continuar a atuar na contenção da ameaça tecnocrática e 
desenvolver mecanismos amplos de fiscalização e controle da atividade executiva. Entretanto, o desafio que se coloca é como garantir o acesso do Parlamento a todos os conhecimentos e a todas as informações técnicas de que necessita para efetuar seu controle democrático, bem como tornar o debate sobre as questões tidas como eminentemente técnicas permeável ao debate público, porque sozinho não será capaz de controlar a tecnocracia.

11. O Parlamento se submete politicamente ao Poder Executivo em virtude da "patronagem" e do poder de agenda deste último, abdicando de sua função legislativa, sobre tudo em matéria econômica, e de sua missão institucional de exercer o controle do poder político. Esse comportamento pode ser explicado por ser eleitoralmente interessante para os parlamentares. Assim, a realização do controle democrático do poder político pelo Parlamento só é possível se essa instituição se submeter ao controle democrático da população, tanto sob o ponto de vista da legitimidade do exercício dessa função, como no da eficiência, pois, em caso contrário, predominarão os interesses egoísticos a motivarem sua omissão.

12. A atuação do Parlamento na definição do Orçamento Público é fundamental para o cumprimento de sua missão institucional. O reconhecimento do caráter impositivo do Orçamento Público é um passo importante, porém não suficiente para se reforçar o controle do Parlamento sobre o direcionamento dos recursos públicos. Observa-se, a esse respeito, que o problema não está no excesso de interferência do Parlamento na definição do Orçamento Público, mas na sua falta. A participação do Parlamento não deveria ficar restrita a uma pequena parcela dos recursos disponíveis para investimentos, deveria abranger todas as linhas gerais do Orçamento. Todavia, ressalta-se que, antes disso, seria necessária uma maior participação do Parlamento na definição das diretrizes da política econômica, pois se trata de um grande fator limitador da própria formulação das leis orçamentárias pelo Executivo. Quanto ao fato de os parlamentares participarem da formulação da agenda do governo, é preciso ponderar que essa participação se restringe a uma pequena elite. Além de que, como a chance de execução das emendas dos parlamentares situacionistas ser muito maior do que a dos oposicionistas (e a execução de emendas tem um grande peso eleitoral), acaba-se induzindo a ampliação do apoio ao governo independentemente da concordância com a política que desenvolve. Além disso, o fato de existir uma lógica partidária no posicionamento dos parlamentares como governistas ou oposicionistas, tanto nas votações como na execução das emendas, é explicado também pelo alto índice de migração partidária em direção aos partidos da base 
do governo, à qual se costumava assistir no início de cada legislatura, antes que fosse firmado o novo entendimento segundo o qual parlamentares que mudam de partido podem perder seus mandatos.

13. A incapacidade de o sistema político desempenhar satisfatoriamente sua função de tomar decisões que vinculem a coletividade, notadamente a fim de expandir a cidadania e de concretizar direitos humanos, precisa ser enfrentada por meio de ajustes no próprio sistema político, e não por meio da transferência das atribuições desse sistema para o sistema jurídico, pois este apresenta outra função e outra forma de operação, de maneira que não se aperfeiçoará o funcionamento de um e se criarão dificuldades para o funcionamento de outro. Portanto, não será por meio dos tribunais que se superará a crise do circuito governo-parlamento, mas sim com reformas nessas próprias instituições.

14. A realização da democracia por meio da representação política encontra muitos limites, mostrando-se incapaz de operar, satisfatoriamente, o controle político, sua função infungível. Da mesma maneira, a regra da maioria, instrumento fundamental por meio do qual a representação se opera, também não resolve todas as questões que lhes são apresentadas. Porém, não existem alternativas capazes de substituir satisfatoriamente tanto a representação política como a regra da maioria. A alternativa que resta, então, é conviver com essas limitações, procurando minimizá-las, e aceitar-se o fato de que as decisões que afetam a coletividade podem ser tomadas em outros espaços, que não o estatal, pois o Estado não detém a exclusividade da esfera pública. Ressalta-se, todavia, que tais espaços de mediação podem completar o estatal-representativo, mas não substituí-lo.

15. O sistema eleitoral mais adequado para o Brasil é o proporcional com listas partidárias fechadas, pois garante maior representatividade e contribui para o fortalecimento dos partidos políticos. Porém, é necessário democratizar o sistema decisório interno dos partidos e proibir as coligações proporcionais. É preciso também estabelecer a igualdade de representatividade entre a população dos diferentes estados. Por fim, destacase a necessidade de se limitar as despesas, estabelecendo-se o financiamento público de campanhas, e criar mecanismos de democratização dos meios de comunicação a fim de combater o domínio do poder econômico, especialmente dos meios de comunicação de massa, sobre o processo político.

16. O controle popular sobre o Parlamento, além das eleições, deve abranger a fixação de diretrizes e metas de médio e longo prazo, o acompanhamento do cumprimento dessas orientações políticas e a responsabilização dos parlamentares se não forem cumpridas, sobretudo por meio do instituto do "recall". Todavia, não se pode atribuir 
exclusivamente às reformas institucionais a responsabilidade por resolver todos os problemas da política. Da mesma maneira, não é somente por meio de canais institucionalizados que o povo pode controlar o Parlamento. Isso também pode ser feito valendo-se de métodos informais, como a formação informal da opinião pública na esfera pública, aberta a todos os cidadãos, a qual pode influenciar as decisões políticas. Para tanto, requer-se um Parlamento poroso a uma opinião pública permanentemente mobilizada. 


\section{BIBLIOGRAFIA FINAL}

ABRAMOVAY, Pedro Vieira e PAULA, Felipe de. Em defesa das ideias. Folha de São Paulo, São Paulo, 15 de maio de 2009, p. A 3.

ABRANCHES, Sérgio Henrique Hudson de. Presidencialismo de Coalizão: O Dilema Institucional Brasileiro. In: Dados - Revista de Ciências Sociais. Vol. 31, n. ${ }^{\circ}$ 1, 1988. P. 5 - 33.

O Sistema Político Partidário. In: JAGUARIBE, Helio (org.). Sociedade, Estado e partidos na atualidade brasileira. $4^{\mathrm{a}}$ ed.. São Paulo, SP: Paz e Terra, 1992. P. 157 - 189.

AMORIM NETO, Octavio e SANTOS, Fabiano. A Produção Legislativa do Congresso - Entre a Paróquia e a Nação. In: VIANNA, Luiz Werneck. A democracia e os Três Poderes no Brasil. Belo Horizonte: UFMG, 2002. P. 91 - 137.

ARISTÓTELES. Política. Trad. Torrieri Guimarães. São Paulo: Martin Claret, 2003.

ARNOLD, R. Douglas. The Logic of Congress Action. $3^{\text {a }}$ ed.. New Haven: Yale University, 1990. P. 3 - 16; $265-276$.

BAPTISTA, Patrícia Ferreira. O Princípio da Separação de Poderes Revisitado e Atualizado. Revista de Direito da Associação dos Procuradores do Novo Estado do Rio de Janeiro, Rio de Janeiro, pp. 9 - 19, 2000.

BARATA, Luiz Roberto Barradas. Regulamentar é o Melhor Caminho. Folha de São Paulo, São Paulo, 17 mar. 2007. Primeiro Caderno, p. A3.

BARROS, Sérgio Rezende de. As Políticas Públicas e o Poder Judiciário. Aula ministrada no Curso de Mestrado da Escola Paulista de Direito - EPD no dia 04 de agosto de 2007a, $15 \mathrm{p}$.

2007b, ano 13, n. 149. Livros, pp. $1-3$.

Entrevista. Tribuna do Direito, São Paulo, set.

Estado de Direito e Políticas Públicas. Aula proferida na Escola Paulista de Direito em 4 de agosto de 2007c, 8 p.

Estado de Direitos Adquiridos. Aula ministrada no

Curso de Mestrado da Escola Paulista de Direito - EPD, 18 p.

BASTOS, Celso Ribeiro, MARTINS, Ives Gandra. Comentários às Constituição do Brasil. V. 1. São Paulo: Saraiva, 1988.

do Brasil. V. 2. São Paulo: Saraiva, 1988.

Comentários às Constituição

Comentários às Constituição

do Brasil. V. 4. São Paulo: Saraiva, 1995. 
BASTOS, Celso Ribeiro. Curso de teoria do Estado e ciência política. $3^{\mathrm{a}}$ ed.. São Paulo: Saraiva, 1995.

BeEthaM, David. Max Weber y La Teoria Politica Moderna. Madrid: Centro de Estudios Constitucionales, 1979.

The Legitimation of Power. Houndmills: Macmillan, 1991.

BENDIX, Reinhard. Max Weber - Um Perfil Intelectual. Trad. Hanna, Elisabeth, Viegas Filho, José. Brasília : Unb, 1986.

BERCOVICI, Gilberto. Desigualdades Regionais, Estado e Constituição. Tese (Doutorado em Direito do Estado) - Faculdade de Direito da Universidade de São Paulo, São Paulo, 2000. P. 21 - 42.

- Planejamento e políticas públicas: por uma nova compreensão do papel do Estado. In: BUCCI, Maria Paula Dallari (org.). Políticas Públicas: reflexões sobre o conceito jurídico. São Paulo: Saraiva, 2006. P. 143 - 161.

BOBBIO, Norberto. A teoria das formas de governo. $10^{\mathrm{a}}$ ed. Trad. Sérgio Bath. São Paulo: Unb, 1998.

Nogueira. São Paulo: Brasiliense, 1990.

O Futuro da Democracia. $7^{\circ}$ ed.. Trad. Marco Aurélio Nogueira. Rio de Janeiro: Paz e Terra, 2000.

Qual Socialismo- debate sobre uma alternativa. Trad. Iza de Slles Frenza. Rio de Janeiro: Paz e Terra, 1983.

BONAVIDES, Paulo. A Constituição Aberta. $3^{a}$ ed.. São Paulo: Malheiros, 2004. P. $17-51 ; 281-286$.

Teoria do Estado. $5^{\text {a }}$ ed.. São Paulo: Malheiros, 2004.

BORSANI, Hugo. Relações entre política e economia: Teoria da Escolha Pública. In: ARVATE, Paulo Roberto. Economia do Setor Público no Brasil. Rio de Janeiro: Elsevier, 2004. P. $103-125$.

BRITTO, Cezar. O caso Renan e a reforma política. Folha de São Paulo, São Paulo, 16 set. 2007. Primeiro Caderno, p. A3.

BUCCI, Maria Paula Dallari. Direito Administrativo e Políticas Públicas. Tese (Doutorado em Direito do Estado) - Faculdade Direito da Universidade de São Paulo, São Paulo, 2001. 


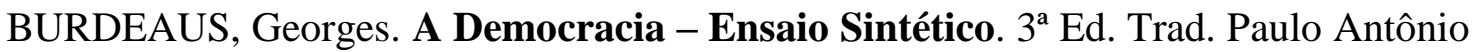
dos Anjos. São Paulo: Europa - América, 1975. P. 9 - 129.

BURKE, Edmund. Textos Políticos. México, D.F: Fondo de Cultura Económica, 1942. P. $309-314$.

CAETANO, Marcelo. Manual de Ciência Política e Direito Constitucional. $4^{\mathrm{a}}$ ed.. Lisboa: Coimbra, 1963. P. 152 - 166.

CAGGIANO, Mônica Herman. O Parlamento no cenário político do século XXI. Revista do Advogado, São Paulo, ano XXIII, n. 73, p. 146 - 166, nov. 2003.

. Sistemas Eleitorais X Representação Política.

Tese (Doutorado em Direito do Estado) - Faculdade de Direito da Universidade de São Paulo, São Paulo, 1987.

CAMARGO, Heloísa Helena Tartarotti, KAIN, Maria de Lourdes de Medeiros. O Senado como controlador externo. Revista de Informação Legislativa, n. ${ }^{\circ}$ 125, p. 207 - 234. Brasília: Senado Federal, 1995.

CAMPILONGO, Celso Fernandes. Direito e Democracia. $2^{\text {a }}$. ed.. São Paulo: Max Limonad, 2000.

São Paulo: Max Limonad, 2002.

Política, Sistema Jurídico e Decisão Judicial.

Os Desafios do Judiciário: um Enquadramento

Teórico. In: FARIA, José Eduardo (org.). Os Direitos Humanos, Direitos Sociais e Justiça. São Paulo: Malheiros, 1998. P. 30 - 51.

Representação Política e Ordem Jurídica: os dilemas da democracia liberal. Tese (Dissertação de Mestrado em Filosofia e Teoria Geral do Direito) - Faculdade de Direito da Universidade de São Paulo, São Paulo, 1987.

CANOTILHO, Joaquim Gomes. Direito Constitucional. 6 ${ }^{\mathrm{a}}$ ed.. Coimbra: Almedina, 1993. 1228p.

CARAJELOSCOV, Yuri. Comissões Parlamentares de Inquérito - à Luz das Disciplinas Constitucional, Legal e Jurisprudencial Luso-Portuguesa e Brasileira. Curitiba: Juruá, 2007.

CASTRO, Marcos Faro de. Instituições Econômicas: Evolução de seus Elementos Constitucionais na Sociedade de Mercado. Revista de Direito Empresarial, Curitiba, n. 6 , p. $41-62$, jul./dez. 2006.

CINTRA, Marcos. Reeleição não faz bem à democracia. São Paulo: Folha de São Paulo, 08/07/2009, Primeiro Caderno, p. A3. 
CASTRO, Marcos Faro de. Julgar a Economia. Revista do Tribunal Superior do Trabalho, Brasília, v. 68, n. ${ }^{\circ}$ 1, pp. 190 - 203, jan./mar. 2002.

CLÈVE, Clèmerson Merlin. Atividade Legislativa do Poder Executivo no Estado Contemporâneo e na Constituição de 1988. São Paulo: Revista dos Tribunais, 1993.

COHEN, Joshua. Democracy and Liberty. In: ELSTER, Jon. Deliberative democracy. Cambridge, U.K.; New York: Cambridge University, 1998, 1999. P. 185 - 227.

COMPARATO, Fábio Konder. Ensaio sobre o Juízo de Constitucionalidade de Políticas Públicas. Revista dos Tribunais, ano 86, v. 737, p. 11 - 22, mar. 1997.

Moderno. São Paulo: Companhia das Letras, 2006.

Ética: Direito, Moral e Religião no Mundo Marinheiro sem rumo nem vento ajuda. Folha de São Paulo, São Paulo, 22 nov. 2007a. Primeiro Caderno, p. A3.

Proposta de reformulação do sistema eleitoral brasileiro.

In: Estudos Eleitorais, v. 1, n. 3, p. 89-101, set./dez., 1997, EE 1/3.

. Quem tem medo do povo? Folha de São Paulo, São

Paulo, 13 mar. 2007b. Primeiro Caderno, p. A3.

, SALOMÃO FILHO, Calixto (atualizador). O Poder de

Controle na Sociedade Anônima. $4^{\mathrm{a}}$ ed. Rio de Janeiro: Forense, 2005.

COTTA, Maurizio. Parlamento. In: BOBBIO, Norberto et alli. Dicionário de Política. Trad. João Ferreira. $7^{a}$ ed., Brasília: UNB, 1995.

COUTINHO, Jacinto Nelson de Miranda (org). Canotilho e a Constituição Dirigente, Rio de Janeiro: Renovar, 2003. 130p. Nota: transcrição de intervenções orais das Jornadas sobre a Constituição dirigente em Canotilho, ocorrida entre os dias 21 e 22 de fevereiro de 2002 na Pousada Cainã, próxima a Curitiba.

CUÉLlAR, Leila. As Agências Reguladoras e seu Poder Normativo. São Paulo: Dialética, 2001.

CUNHA, Sérgio Sérvulo da. Reforma Eleitoral-partidária. Revista de Informação Legislativa. A. 32, n. 125, jan.-mar. 1995, p. $5-12$.

DAHL, Robert A.. Poliarquia - Participação e Oposição. Trad. Celso Mauro Pacionik. São Paulo: Universidade de São Paulo, 1997. 234p.

. Um prefácio à democracia econômica. $3^{\mathrm{a}} \mathrm{ed}$. Trad: Jungmann, Ruy. Rio de Janeiro: Zahar, 1990. P. 73 - 91.

DALLARI, Dalmo de Abreu. Elementos de Teoria Geral do Estado. 22a ed.. São Paulo: Saraiva, 2001. 307p. 
DEWEY, John. Liberalismo, Liberdade e Cultura. Trad. Anísio Teixeira. São Paulo: Nacional, 1970.

DÍAZ, Elías. Estado de Derecho y sociedad democrática. Madri, Cuadernos para El Diálogo, 1973. P. 9 - 43.

DOWNS, Anthony. Uma Teoria Econômica da Democracia. Trad. Sandra Guardini Teixeira Vasconcelos. São Paulo: Universidade de São Paulo, 1999.

DEGUIT, Léon. Elementos do Estado. Trad. Eduardo Salgueiro. Lisboa: Inquérito, 1939. P. $20-43$.

DUVERGER, Maurice. As Modernas Tecnodemocracias: poder econômico e poder político. Rio de Janeiro: Paz e Terra, 1975.

Ariel, 1962. P. $78-121$.

Instituciones políticas y derecho constitucional. Barcelona:

Os Partidos Políticos. Trad. Cristiano Monteiro Oiticica. Rio de

Janeiro: Zahar, 1970.

EICHENGREEN, Barry. A Globalização do Capital. Trad. Ségio Blum, São Paulo: 34, 2000.

ELSTER, Jon. Deliberative democracy. Cambridge, U.K.. New York: Cambridge University, 1998, 1999. P. 1 - 17; $185-227$.

Caderno, A25.

Entrevista. Folha de São Paulo, São Paulo, 17 jun. 2007. Primeiro

FARIA, José Eduardo. Direito e Justiça no Século XXI: a Crise da justiça no Brasil (texto preparado para o seminário Direito e Justiça no Século XXI). Coimbra: Centro de Estudos Sociais, de 20 de maio a $1^{\circ}$ de junho de 2003.

Eficácia Jurídica e Violência Simbólica: o direito como instrumento de transformação social. São Paulo: Universidade de São Paulo, 1988.

Informação e Democracia. Revista do Advogado, São Paulo, ano XXIII, $\mathrm{N}^{\circ} 69$, p. 7 - 15, Maio/2003.

Malheiros, 2002.

O Direito na Economia Globalizada. $1^{\text {a }}$ ed.. São Paulo:

O Judiciário e os Direitos Humanos e Sociais: Notas para uma Avaliação da Justiça Brasileira. In: FARIA, José Eduardo (org.). Direitos Humanos, Direitos Sociais e Justiça. São Paulo: Malheiros, 1998. P. 94 - 111.

Poder e Legitimidade (Uma Introdução à Política do Direito). 1976. Tese (Mestrado em Filosofia e Teoria Geral do Direito) - Faculdade de Direito da Universidade de São Paulo, São Paulo. 
Retórica Política e Ideologia Democrática: a legitimação do discurso jurídico liberal. Tese (Livre-docência em Filosofia e Teoria Geral do Direito) - Faculdade de Direito da Universidade de São Paulo, São Paulo, 1982.

FAVETTI, Rafael Thomaz. Controle de Constitucionalidade e Política Fiscal. Porto Alegre: Sérgio Antônio Fabris, 2003.

FERRAJOLI, Luigi. Direito e Razão - Teoria do Garantismo Penal. $2^{\mathrm{a}}$ ed. Trad. Ana Paula Zomer Sica et. alli. São Paulo: Revista dos Tribunais, 2006.

FERRAZ, Anna Cândida da Cunha. O poder congressual de sustar atos normativos do Poder Executivo. Tese (Livre-docência em Direito do Estado) - Faculdade de Direito da Universidade de São Paulo, São Paulo, 1993.

FERRAZ JÚNIOR, Tercio Sampaio. O Judiciário Frente à divisão de poderes: um princípio em decadência? Revista USP - Dossiê Judiciário, São Paulo, n. 21, p. 12 21, mar./mai. 1994.

FERREIRA FILHO, Manoel Gonçalves. Curso de Direito Constitucional. $30^{\mathrm{a}}$ ed.. São Paulo: Saraiva, 2003. 371 p.

Saraiva, 1988. 129p.

. Estado de Direito e Constituição. São Paulo:

1968. 251 p..

. Do Processo Legislativo. São Paulo: Saraiva,

FERREIRA, Pinto. Curso de Direito Constitucional. $7^{\text {a }}$ ed. São Paulo: Saraiva, 1995.

FIGUEIREDO, Argelina Cheibub, LIMONGI, Fernando. Congress and decisionmaking in democratic Brazil. In: KINZO, Maria D'Alva, DUNKERLEY, James (ed). Brazil since 1985: politics, economy and society. London: Institute of Latin American Studies, 2003a. P. 62-83.

na nova ordem constitucional. $2^{a}$ ed. Rio de Janeiro: FGV/FAPESP, 2001. 231p.

Executivo e Legislativo , VALENTE, Ana Luzia.

Governabilidade e concentração de poder institucional - o Governo FHC. In: Tempo Social - Revista de Sociologia da USP, São Paulo, v.11, n.2, p. 49 - 62, out. 1999.

Política Orçamentária no

Presidencialismo de Coalizão. Rio de Janeiro: Fundação Getúlio Vargas, 2008.

Legislative Organization, and Party Behavior in Brazil. In: DAHL, Robert, SHAPIRO, Ian, CHEIBUB, José Antônio, The democracy sourcebook. Cambridge: Mit, 2003b. P. 304 - 309. 
FIORI, José Luís. Globalização, Hegemonia, Império. In: FIORI, José Luís e TAVERES, Maria da Conceição (org.). Poder e dinheiro: uma economia política da globalização. Petrópolis-RJ: Vozes, 1997. P. 87 - 147.

FREITAS, Janio de. Se ainda for possível. Folha de São Paulo, São Paulo, 03/05/2009, Primeiro Caderno, p. A 10.

Primeiro Caderno, p. A 9.

Um país dividido. Folha de São Paulo, São Paulo, 19/07/2009,

FRISCHEISEN, Luiza Cristina Fonseca. Construção da Igualdade e o Sistema de Justiça no Brasil: Alguns Caminhos e Possibilidades. 2004. 139p. Tese (Doutorado em Filosofia e Teoria Geral do Direito) - Faculdade de Direito da Universidade de São Paulo, São Paulo.

. Políticas Públicas - A responsabilidade do

administrador e o ministério público. São Paulo: Max Limonad, 2000.

GIANOTTI, José Arthur. A nova política. Folha de São Paulo, São Paulo, 24/05/2009, Caderno Mais! p. 6.

GIORGI, Raffaelle De. Luhmann e a Teoria Jurídica dos Anos 70. In: CAMPILONGO, Celso Fernandes. O Direito na Sociedade Complexa. São Paulo: Max Lomonad, 2000, 195p.

GORDILlO, Agustín. Problemas Del control de La Administración Publica en América Latina. Madrid: Civitas, 1981.

GRIFFITH, J. A. G., RYLE, Michael, WHEELER-BOOTH, M. A. J.. Parliament Functions, Practice and Procedures. London: Sweet \& Maxwell, 1989.

GUIMARÃES, Débora Messenberg. A Elite Parlamentar do Pós-Constituinte: Atores e Práticas. Tese (Doutorado em Sociologia) - Faculdade de Filosofia Letras e Ciências Humanas da Universidade de São Paulo, São Paulo, 2000.

HABERMAS, Jürgen. Direito e Democracia - Entre facticidade e validade. V. 1. Trad. Flávio Beno Siebeneichler. Rio de Janeiro: Tempo Brasileiro, 1997.

Direito e Democracia - Entre facticidade e validade. V. 2. Trad. Flávio Beno Siebeneichler. Rio de Janeiro: Tempo Brasileiro, 1997.

HAMILTON, Alexander, MADISON, James, JAY, John. O Federalista. $2^{\mathrm{a}}$ ed.. In: Os Pensadores. São Paulo: Abril, 1979.

HAYEK, Friedrich August. Os Fundamentos da Liberdade. Trad. Anna Maria Capovilla e José Ítalo Stelle. Brasília: Universidade de Brasília, 1983. 522p.

HELLER, Hermann. Teoría Del Estado. Trad. Luis Tobio. México: Fondo de Cultura Econômica, 2002. 
HUME, David. Ensaios Políticos. Trad. E. Jacy Monteiro. São Paulo: Instituição Brasileira de Difusão Cultural, 1963. 163 p..

IANNI, Octavio. Estado e Capitalismo. $2^{\text {a }}$ ed. São Paulo: Brasiliense, 1989. P. 159 199. v.1, n. 1, jan./jun. 1999. P.252-275.

O Príncipe Eletrônico. In: Sociologias Porto Alegre, Porto Alegre,

JAGUARIBE, Helio (org.). Sociedade, Estado e partidos na atualidade brasileira. $4^{a}$ ed.. São Paulo, SP: Paz e Terra, 1992. P. $11-48$.

JEFFERSON, Thomas (1743 - 1826). Escritos Políticos. Trad. Leônidas Gontijo de Carvalho. $2^{a}$ ed.. In: Os Pensadores. São Paulo: Abril, 1979.

JELLINEK, Georg. Teoria General Del Estado. Trad. Fernando de los Rios. Buenos Aires: Albatros, 1970. P. 463 - 484.

KELSEN, Hans. A Democracia. Trad. Ivone Castilho Benedetti, Jefferson Luiz Camargo, Marcelo Brandão Cipolla, Vera Barkow. São Paulo: Martins Fontes, 2000.

KELSEN, Hans. Teoria Geral do Direito e do Estado. Trad. Luís Carlos Borges. São Paulo: Martins Fontes, 2000.

LAMOUNIER, Bolívar. A democracia brasileira no limiar do século 21. São Paulo: São Paulo: Fundação Konrad Adenauer Stiftung Centro de Estudos, 1996. P. 33 - 58.

21/03/2007. Primeiro Caderno, p. A3.

. O bebê e a água do banho. Folha de São Paulo, São Paulo,

LASKI, Harold. El estado moderno: sus instituciones políticas y econômicas. Trad. Teodoro González García. Barcelona: Bosch, 1932. P. 23 - 61.

LEAL, Victor Nunes. A Divisão de Poderes no Quadro Político da Burguesia. In: Problemas de Direito Público e outros Problemas. Brasília: Ministério da Justiça, 1997 (publicado originalmente em 1954). P. 17 - 36.

Coronelismo, Enxada e Voto. - O Município e o Regime Representativo no Brasil. São Paulo: Alfa-Omega, 1975.

LEVI, Lucio. Legitimidade. In: BOBBIO, Norberto et alli. Dicionário de Política. Trad. João Ferreira. $7^{\text {a }}$ ed., Brasília: UNB, 1995.

LIMONGI, Fernando, FIGUEIREDO, Argelina Cheibub. Bases Institucionais do Presidencialismo de Coalizão. Lua Nova - Revista de Cultura e Política, São Paulo, n. ${ }^{\circ} 44$, p. $81-106,1998$.

LEWANDOWSKI, Enrique Ricardo. Globalização, Regionalização e Soberania. São Paulo: Juarez de Oliveira, 2004. 
LINZ, Juan. Presidential or Parlamentary Democracy: Does It Make a Difference? In: LINZ, Juan e VALENZUELA, Arturo (ed.). The Failure of Presidential Democracy: Comparative Perspectives. V. 2. $2^{\mathrm{a}}$ Ed. Baltimore: Johns Hopkins University, 1994. P. $3-72$.

LOEWENSTEIN, Karl. Teoria de La Constituición. Trad. Alfredo Gallego Anabiarte. Barcelona: Ariel, 1986.

LOCKE, John. Segundo Tratado sobre o Governo Civil. Trad. Alex Marins. São Paulo: Martin Claret, 2003. 176 p.

LOPES, José Reinaldo de Lima. A Função Política do Poder Judiciário; In: FARIA, José Eduardo (org.). Direito e Justiça - A Função Social do Judiciário. São Paulo: Ática, 1989. P. 123 - 144.

Crise da Norma Jurídica e Reforma do Judiciário. In: FARIA, José Eduardo (org.). Direitos Humanos, Direitos Sociais e Justiça. São Paulo: Malheiros, 1998a. P. 68 - 93.

Direito Subjetivo e Direitos Sociais: O Dilema do Judiciário no Estado Social de Direito. In: FARIA, José Eduardo (org.). Direitos Humanos, Direitos Sociais e Justiça. São Paulo: Malheiros, 1998b. P. 113 - 143.

Raciocínio Jurídico e Economia. Revista de Direito

Público da Economia, Belo Horizonte, ano 2, n. ${ }^{\circ}$ 8, pp. 137 - 170, out./dez. 2004.

LOUREIRO, Maria Rita. Os economistas no Governo: gestão econômica e democracia. Rio de Janeiro: Fundação Getúlio Vargas, 1997. P. 117 - 178.

LUHMANN, Niklas. The Position of Courts in the Legal System. In: Law as a Social System. Oxford. P. $274-304$.

Le Funzioni Della Giurisdizione Nel Sistema Político. In: Stato di Diritto e Sistema Sociale. Napoli: Guida, 1969. P. 53 - 64.

MACIEL, Marco. Para andar a reforma política. Folha de São Paulo, São Paulo, 21/04/2009, Primeiro Caderno, p. A 3.

MACPHERSON, C. B.. A Democracia Liberal - Origens e Evolução. Trad. Nathanael C. Caixeiro. Rio de Janeiro: Zahar, 1978. P. 29 - 116.

MADSON, James. In: LIMONGI, Fernando Papaterra. "O Federalista": remédios republicanos para males republicanos. In: WEFFORT, Francisco C. (org). Os Clássicos da Política. V. 1. $13^{\mathrm{a}}$ ed.. São Paulo: Ática, 2001. P. 244 - 287.

MAIA, César. Contraconstitucionalidade. Folha de São Paulo, São Paulo, 06/07/2006. Primeiro Caderno, p. A3.

Barebones Parliament. Folha de São Paulo, São Paulo, 14/02/2009, Primeiro Caderno, p. A 2. 
MALBERG, Raymond Carre de. Teoria General Del Estado. Trad. José Lion Depetre. Pánuco (México): Fondo de Cultura Econômica, 1948.

MANCUSO, Rodolfo de Camargo. A Ação Civil Pública como Instrumento de Controle Judicial das Chamadas Políticas Públicas. In: MILARÉ, Edis (coord). Ação Civil Pública - Lei 7347/1985 - 15 anos. São Paulo: Revista dos Tribunais, 2001, pp. $707-751$.

MARSHAL, T. H.. Cidadania, Classe Social e Status. Rio de Janeiro: Zahar, 1967. P. $87-114$.

MARTIN, Hans-Peter e SCHUMANN, Harald. A Armadilha da Globalização - O assalto à democracia e ao bem-estar social. Trad. Waldtraut U. E. Rose e Clara C. W. Sackiewicz. São Paulo: Globo, 1997. P. 273 - 333.

MARX, Karl e ENGELS, Friedich. Manifesto comunista. $1^{\mathrm{a}}$ ed.. São Paulo: Boitempo, 2005. P. $39-69$.

Prefácio à Contribuição à Crítica da Economia Política, Trad. Maria Helena Barreiro Alves. São Paulo: Martins Fontes: 2003. P. 3 - 8.

MAUS, Ingborg. Judiciário como Superego da Sociedade - O Papel da Atividade Jurisprudencial na "Sociedade Órfã". Novos Estudos CEBRAP, São Paulo, n. ${ }^{\circ}$ 58, p. 183 - 202, nov. 2000.

MAYER, Dayse Vasconcelos. A democracia eletrônica: a questão das sondagens de opinião e dos mass media no sistema eleitoral. Estudos Eleitorais, v. 1, n. 3, p. 31-54, set./dez., 1997, EE 1/3.

MEDAUAR, Odete. Controle parlamentar da Administração. Revista de Informação Legislativa, Brasília, a. 27, nº 107, p. 111 - 130, jul./set., 1990.

MELO, José Tarcízio de Almeida. Origens, Evolução e Características do Regime Parlamentar de Governo. RDP, n. ${ }^{\circ}$ 100, 1991, p.138 - 146.

MELO, Marcus André. A Política da Ação Regulatória: responsabilização, credibilidade e delegação. RBCS, vol. 16, n. ${ }^{\circ}$ 46, jun./2001.

MILL, John Stuart (1806 - 1873). O Governo Representativo. $2^{\text {a }}$ ed. Trad. Jacy Monteiro. São Paulo: Ibrasa, 1983. P.34 - 49; 60 - 108.

MONTESQUIEU. Do Espírito das Leis. $1^{\circ}$ vol. Trad. Fernando Henrique Cardoso e Leôncio Martins Rodrigues. São Paulo: Difusão Européia do Livro, 1962.

MORAES, Alexandre de. Direito Constitucional. 17ª ed. São Paulo: Atlas, 2005.

MORAES FILHO, José Filomeno de. Separação de Poderes no Brasil Pós-88: Princípio Constitucional e Práxis Política. In SOUZA NETO, Cláudio Pereira de et al. 
(org.). Teoria da constituição: estudos sobre o lugar da política no direito constitucional. Rio de Janeiro: Lumen Juris, 2003. P. 151 - 197.

MORAIS, Carlos Blanco de. Democracia e Consenso na Decisão de Legislar. Revista Brasileira de Direito Constitucional, n. ${ }^{\circ}$ 3, São Paulo, p. 117 - 186, jan./jun. 2004.

NINO, Carlos Santiago. The Constitution of deliberative democracy. Yale: Yale University, 1996. P. $67-143$.

OFFE, Claus. A democracia contra o Estado de bem-estar? - fundamentos estruturais das oportunidades políticas neoconservadoras. In OFFE, Claus. Capitalismo Desorganizado - Transformações Contemporâneas do Trabalho e da Política. Trad. Brant, Wanda Caldeira. São Paulo: Brasiliente, 1995. P. 269 - 317.

Critérios de Racionalidade e problemas funcionais da ação políticoadministrativa. In: Problemas estruturais do Estado Capitalista. Trad. Fraitag, Bárbara. Rio de Janeiro: Tempo Brasileiro, 1984. P. 216 - 233.

OLIVEIRA, Marques. O Controle, esse desconhecido. São Paulo: Revista dos Tribunais, 1983. P. $1-42$.

PALUDO, Januário. O Senado no Estado Contemporâneo. Tese (Dissertação de Mestrado) - Faculdade de Filosofia Ciências e Letras da Universidade de São Paulo, São Paulo, 1999

PIERSON, Christopher. Democracy, Markets and Capital: are there necessary Economic Limitas to Democracy? In: HELD, David. Prospects for Democracy. Standford: Standford University, 1993. P. 179 - 1999.

PIÇARRA, Nuno. A separação dos poderes como doutrina e princípio constitucional: um contributo para o estudo das suas origens e evolução. Coimbra: Coimbra, 1989. p. 11 - 27; 41 - 62; 143 - 147; $229-265$.

PINHEIRO, Luís Felipe Valerim. Orçamento Impositivo: Fundamentos e Limites Jurídicos. Tese (Mestrado em Direito Econômico e Financeiro) - Faculdade de Direito da Universidade de São Paulo, São Paulo, 2007.

PROVENZA, Vittorio Constantino. Da Separação das Funções à Limitação do Poder. Entendendo a Intrincada Engenharia de Controle. Revista de Direito da Associação dos Procuradores do Novo Estado do Rio de Janeiro, Rio de Janeiro, p. 33 - 53, 2000.

REAL, Ramon. El Control de la Administración. Revista de Direito Público, $\mathrm{n}^{\text {o }} 32$, pp. 5 - 16. Nov./dez. 1974.

REALE, Miguel. Teoria do Direito e do Estado. $2^{\text {a }}$ ed.. São Paulo: Martins, 1960.

RIBEIRO, Renato Jorge Brown. O Problema Central do Controle da Administração Pública Pode Ser Resumido ao Debate sobre Modelos? Revista do Tribunal de Contas da União, Brasília, v. 33, n. 93, p. 55 - 73. jul./set. de 2002. 
ROCHA, Jean Paul Cabral Veiga da. A capacidade normativa de conjuntura no Direito Econômico: o déficit democrático da regulação financeira. Tese (Doutorado em Direito Econômico-Financeiro) - Faculdade de Direito da Universidade de São Paulo, São Paulo, 2004. P. 11 - 31; 64 - 108; 175 - 195.

ROMANO, Roberto. Espantalho de Poder Legislativo. Folha de São Paulo, São Paulo, 13/05/2006, Primeiro Caderno, p. A 3.

ROSE, Nikolas, MILLER, Peter. Political power beyond the State: problematics of government, jun./1992, pp. $173-205$.

ROSSI, Clóvis. Contadores de histórias. E só. Folha de São Paulo, São Paulo, 10/06 2008, Primeiro Caderno, p. A2.

ROUSSEAU, Jean-Jaques. Do Contrato Social. Trad. Pietro Nassetti. São Paulo: Martin Claret, 2000.

SAldANHA, Nelson. O Estado Moderno e a Separação de Poderes. São Paulo: Saraiva, 1987. P. $3-5 ; 81-124$.

. Separação de Poderes - Curso: O Poder Legislativo. Brasília: Departamento de Imprensa Nacional, 1981. P. 22 - 35.

SANTOS, Boaventura de Souza. Democratizar a democracia - os caminhos da democracia participativa. Rio de Janeiro: Civilização Brasileira, 2002.

et. ali. Os Tribunais nas

Sociedades

Contemporâneas: o caso português. $2^{a}$ ed.. Porto: Afrontamento, 1996.

Pela Mão de Alice - O social e o político na pósmodernidade. $7^{\mathrm{a}}$ ed.. São Paulo: Cortez, 2000.

SANTOS, Fabiano. O Congresso não é mais dos plutocratas. Folha de São Paulo, São Paulo, 13/05/2006, Primeiro Caderno, p. A 3.

Patronagem e Poder de Agenda na Política Brasileira. Dados Revista de Ciências Sociais. V. 40. N. 3. Rio de Janeiro: Instituto Universitário de Pesquisas do Rio de Janeiro (IUOERJ), 1997. P. 465 - 488.

SANTOS, Maria Helena de Castro. Governabilidade, Governança e Democracia: Criação de Capacidade Governativa e Relações Executivo-Legislativo no Brasil Pós Constituinte. Dados - Revista de Ciências Sociais. V. 40. N. 3. Rio de Janeiro: Instituto Universitário de Pesquisas do Rio de Janeiro (IUOERJ), 1997. P. 335 - 376.

SARTORI, Giovanni. A Teoria da Democracia Revisitada. Trad. Dinah de Abreu Azevedo. São Paulo: Ática, 1994. 
A Teoria da Representação no Estado Representativo

Moderno. Trad. Ernesta Gaetani e Rosa Gaetani. Belo Horizonte: Revista Brasileira de Estudos Políticos, 1962. 141 p.

SCHMITT, Carl. A Crise da Democracia Parlamentar. Trad. Inês Lohbauer. São Paulo: Scritta, 1996 (2 $2^{\text {a }}$ edição publicada em 1926). P. 3 - 48.

SCHUMPETER, Joseph Alois. Capitalismo, Socialismo e Democracia. Trad. Jungmann, R.. Rio de Janeiro: Fundo de Cultura, 1961. P. 305 - 366.

SCHWARTZ, Bernard. Direito Constitucional Americano. Trad. Nayfeld, Carlos. Rio de Janeiro: Forense, 1966, c1955. P. 27 - 44; 72 - 112.

SCHWARTZENBERG, Roger-Gérard. O Estado Espetáculo: ensaio sobre e contra o star system em política. Trad. Heloysa de Lima Dantas. Rio de Janeiro: Difel, 1978. P. $127-139 ; 153-168 ; 215-245 ; 317-350$.

SEMER, Marcelo. Garantindo o Exercício de Direitos. Folha de São Paulo, São Paulo, 17/05/2007, Primeiro Caderno, p. A 3.

SILVA, Carlos Alberto Bello e. Hegemonia neoliberal: de FHC a Lula. Texto apresentado no $31^{\circ}$ Encontro Anual da ANPOCS (2007), no Seminário Temático Estrutura Social, Ação Coletiva e Poder Político.

SILVA, José Afonso. Curso de Direito Constitucional Positivo. 19 $9^{\text {a }}$ ed.. São Paulo: Malheiros, 2001. 878 p.

SILVA, Luís Virgílio Afonso da. Sistemas Eleitorais - tipologia, efeitos jurídicopolíticos e o caso brasileiro. Tese (Dissertação de Mestrado em Direito do Estado) Faculdade de Direito da Universidade de São Paulo, São Paulo: 1998.

SINGER, André. Ainda há tempo para mudar. Folha de São Paulo, São Paulo, 12/09/2007, Primeiro Caderno, p. A3.

SIEYES, Emmanuel. Que es el tercer estado? Trad. Ayala, Francisco. Madrid: Aguilar, 1973.

SUORDEM, Fernando Paulo da Silva. O Princípio da Separação de Poderes e os Novos Movimentos Sociais. Coimbra: Almedina, 1995. P. 13 - 100.

TEMER, Michel. Elementos de Direito Constitucional. 17ª ed.. São Paulo: Malheiros Ed., 2001. P. 125 - 134.

TEUBNER, Günter. Juridification - Concepts, Aspects, Limits, Solutions. In TEUBNER, Günter (ed.). Juridification of social spheres: a comparative analyses in the areas of labor, corporate, antitruste and social welfare law. Berlin: Walter de Gruyter, 1987. P. $1-47$. 
TOJAL, Sebastião Botto de Barros. O Controle Judicial da Atividade Normativa das Agências Reguladoras. Revista da Academia Brasileira de Direito Constitucional, Curitiba, V. 2, p. 75 - 103, 2002.

TOCQUEVILLE, Alexis de (1805 - 1859). A Democracia na América. Trad. J. A. G. Albuquerque. $2^{a}$ ed.. In: Os Pensadores. São Paulo: Abril, 1979.

VIANNA, Luiz Werneck et ali. A Judicialização da Política e das Relações Sociais no Brasil. Rio de Janeiro: Revan, 1999. pp. 15 - 44.

VILLA, Marco Antônio. O país do faz de conta. Folha de São Paulo, São Paulo, 03/05/2009, Primeiro Caderno, p. A 3.

WEBER, Max. A política como vocação. In: Ciência e Política - Duas Vocações. Trad. Jean Melville. São Paulo: Martin Claret, 2006.

. Economia y Sociedad - Esbozo de sociologia comprensiva. V. 1. Ed. preparada por Johannes Winckelmann. Cidade do México: Fondo de Cultura Económica, 1964.

. Economia e Sociedade - Fundamentos da Sociologia Compreensiva. V. 2. Trad. Regis Barbosa e Karen Elsabe Barbosa. Brasília: UNB, 1999. 


\title{
Resumo
}

O presente estudo se propõe a investigar em que medida o Parlamento é capaz de exercer, eficazmente, o controle do poder político, no contexto da globalização capitalista, com o objetivo de contribuir com a concretização dos direitos humanos econômicos e sociais. Compreende-se o controle do poder político como o direcionamento das ações do Estado para a realização de seus fins, por meio da fixação de metas e diretrizes, da supervisão e da responsabilização dos agentes políticos. Reconhece-se a importância do Parlamento no desempenho deste papel, porém sua atuação apresenta grandes limites, decorrentes, entre outros fatores, do fenômeno da globalização e da característica histórico-cultural patrimonialista do Estado brasileiro. Diante disso, a sociedade precisa desenvolver outras formas de controle para complementar o parlamentar.

Palavras-chave: Parlamento, controle, poder, política, Estado Democrático de Direito, globalização, direitos econômicos e sociais, patrimonialismo, Representação Política, Separação de Poderes.

\begin{abstract}
This study wants to investigate in which level the Parliament is able to exercise, with efficacy, the control of the political power, in the context of the capitalist globalization, with the objective to contribute with the concretization of the economics and socials human rights. The control of the political power is understood like the direction of de State's actions to the realization of its finalities, by the fixation of objectives and directives, the supervision and the responsabilization of the politics agents. The Parliament has so much importance realizing this paper, but its actuation presents big limits, because some factors, how the phenomenon of the globalization and the historic-cultural characteristic "patrimonialista" of the Brazilian State. So, the society needs to develop other forms of control to complement the parliamentary.
\end{abstract}

Key-words: Parliament, control, power, politic, Democratic State of Law, globalization, economics and socials rights, "patrimonialismo", Political Representation, Separation of Powers. 